\title{
DUAL CITIZENSHIP \\ AND NATURALISATION
}

\section{Global, Comparative and Austrian Perspectives}

Rainer Bauböck and Max Haller (eds)

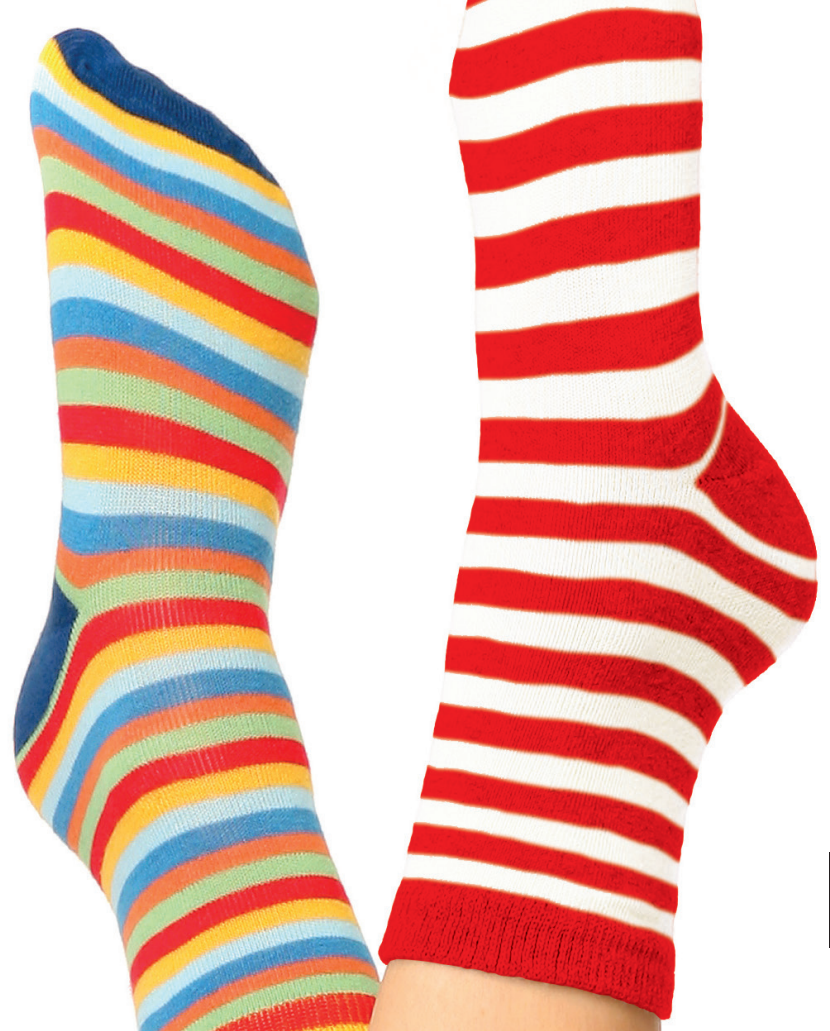


Rainer Bauböck and Max Haller (eds)

Dual Citizenship and Naturalisation:

Global, Comparative and Austrian Perspectives 
Österreichische Akademie der Wissenschaften

Philosophisch-historische Klasse · Sitzungsberichte, 910. Band 
Rainer Bauböck and Max Haller (eds)

\section{Dual Citizenship and Naturalisation: \\ Global, Comparative and Austrian Perspectives}


Accepted by the publication committee of the Division of Humanities and Social Sciences of the Austrian Academy of Sciences:

Michael Alram, Bert G. Fragner, Andre Gingrich, Hermann Hunger, Sigrid Jalkotzy-Deger, Renate Pillinger, Franz Rainer, Oliver Jens Schmitt, Danuta Shanzer, Peter Wiesinger, Waldemar Zacharasiewicz

This publication was subject to international and anonymous peer review.

Peer review is an essential part of the Austrian Academy of Sciences Press evaluation process. Before any book can be accepted for publication, it is assessed by international specialists and ultimately must be approved by the Austrian Academy of Sciences Publication Committee.

The paper used in this publication is DIN EN ISO 9706 certified and meets the requirements for permanent archiving of written cultural property.

All rights reserved.

ISBN 978-3-7001-8775-2

Copyright (c) 2021

Austrian Academy of Sciences, Vienna

Layout: Crossdesign, Graz

Print: Prime Rate, Budapest

https://epub.oeaw.ac.at/8775-2

https://verlag.oeaw.ac.at

Made in Europe 


\section{Table of Contents}

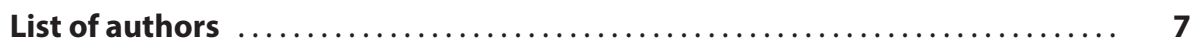

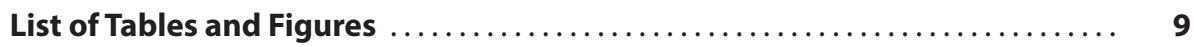

Preface

Rainer Bauböck and Max Haller ................................. 13

1. Introduction

Max Haller and Rainer Bauböck ......................... 17

I. Citizenship Identity and Utility in Global Perspective ............. 31

2. (Dual) Citizenship and National Identity in a Globalised World: Sociological Perspectives

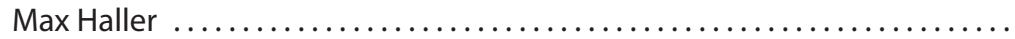

3. The Toleration of Dual Citizenship: A Global Trend and its Limits

Rainer Bauböck ................................... 59

4. The Past and (Post-COVID) Future of Dual Citizenship

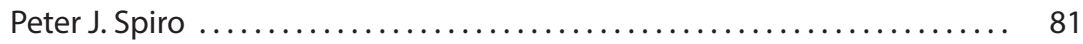

5. Strategic Dual Citizenship: Global Dynamics of Supply and Demand Yossi Harpaz

II. Dual Citizenship in Comparative Perspective

6. Dual Citizenship Acceptance and Immigrant Naturalisation Propensity in the Netherlands: The Relevance of Origin- and Destination-Country Rules

Floris Peters and Maarten Vink

7. Kin Citizenship in Eastern Europe

Szabolcs Pogonyi

8. The Danish Turn Towards Dual Citizenship

Eva Ersbøll

9. Dual Citizenship in Italy: An Ambivalent and Contradictory Issue

Günther Pallaver and Guido Denicolò 
III. Austrian Citizenship at Home and Abroad 205

10. Non-Toleration of Dual Citizenship in Austria Rainer Bauböck and Gerd Valchars

11. The Potential for Naturalisation in Austria:

A Statistical Approximation

Stephan Marik-Lebeck

12. Does Citizenship Promote Integration? An Austrian Case Study of Immigrants from the Former Yugoslavia and Turkey Raimund Haindorfer and Max Haller

13. The View of Expatriate Austrians on Dual Citizenship: The Results of a Worldwide Survey

Florian Gundl

14. Does Dual Citizenship Endanger Ethnic Cohabitation? How the South Tyrolean Population Views a Supplementary Austrian Citizenship

Hermann Atz and Max Haller 293 


\section{List of authors}

Hermann Atz, Political Scientist and Physicist, Partner and CEO of Apollis - Institute of Social Research and Opinion Polling in Bolzano-Bozen. Email: hermann.atz@apollis.it

Rainer Bauböck, Professor at the Robert Schuman Centre of the EUI, Chair of the Commission for Migration and Integration Research (KMI) of the Austrian Academy of Sciences. Email: rainer.baubock@eui.eu

Eva Ersbøll, Senior Researcher Emerita at the Danish Institute for Human Rights. Email: eer@humanrights.dk

Guido Denicolò, Avvocato dello Stato, Avvocatura dello Stato, Trento.

Email: deniguid@tin.it

Florian Gundl, Institute of Sociology, University of Graz, Austria.

Email: florian.gundl@gmail.com

Raimund Haindorfer, Senior-Postdoc, Department of Sociology, University of Salzburg. Email: raimund.haindorfer@univie.ac.at

Max Haller, Emeritus Professor of Sociology, University of Graz, Austria, and Vice-Chair of the Commission for Migration and Integration Research (KMI) of the Austrian Academy of Sciences. Email: max.haller@uni-graz.at

Yossi Harpaz, Assistant Professor, Department of Sociology and Anthropology, Tel-Aviv University. Email: yharpaz@tauex.tau.ac.il

Stephan Marik-Lebeck, Head of the Unit 'Demography and Health' at Statistics Austria. Email: stephan.marik-lebeck@statistik.gv.at

Günther Pallaver, Emeritus Professor of Political Science, University of Innsbruck (Austria). Senior Researcher, Eurac Research, Bolzano/Bozen (Italy).

Email: Guenther.Pallaver@uibk.ac.at

Floris Peters, Postdoctoral Researcher at the Department of Political Science, Maastricht University. Email: floris.peters@maastrichtuniversity.nl

Szabolcs Pogonyi, Associate Professor on the Nationalism Studies Program, Central European University, Vienna. Email: pogonyi@ceu.edu 
Peter J. Spiro, Charles R. Weiner Professor of Law, Temple University, Philadelphia, Co-Director, Institute for International Law and Public Policy. Email: peter.spiro@temple.edu

Gerd Valchars, Political Scientist, Lecturer at the Universities of Vienna and Klagenfurt and at the University of Applied Sciences Campus, Vienna.

Email: gerd.valchars@univie.ac.at

Maarten Vink, Chair of Citizenship Studies, Robert Schuman Centre for Advanced Studies, European University Institute, Florence. Email: maarten.vink@eui.eu 


\section{List of Tables and Figures}

\section{List of Tables}

Table 2.1. The relevance of citizenship among eight characteristics of a person's national identity, as seen by the population in 20 countries in 2013 (\%)

Table 2.2. The identification of immigrants from the former Yugoslavia and from Turkey living in Austria with their countries of origin and destination (\%)

Table 2.3. Characteristics and virtues of a "good citizen": popular opinions in 38 countries around the world in 2013-2014 (\%)

Table 3.1. Dual citizenship in incoming and outgoing naturalisations in 2016

Table 5.1. Prevalence and characteristics of dual citizenship in selected countries

Table 6.1. Descriptive statistics, cohorts 1985-1997

Table 6.2. Cox proportional hazard regression on the risk of naturalisation, cohorts 1985-1997.

Table 9.1. Countries with the highest percentage of Italian citizens in 2019 (in \%)

Table 9.2. Countries of origin of foreign citizens in Italy 2019 (in \%)

Table 11.1. Residents who acquired citizenship as a share of resident non-citizens by former citizenship 2012-2018 in selected EU/EFTA countries (in \%)

Table 11.2. Population in Austria on $1 / 1 / 2020$ by citizenship and length of registered stay

Table 11.3. Population in Austria on $1 / 1 / 2020$ by EU/EFTA citizenship and length of registered stay

Table 11.4. Population in Austria on $1 / 1 / 2020$ by non-EU/EFTA citizenship and length of registered stay

Table 11.5. Population in Austria on $1 / 1 / 2020$ by non-European citizenship and length of registered stay

Table 11.6. Underage population in Austria on $1 / 1 / 2020$ by citizenship and length of registered stay

Table 11.7. Evolution of foreign population in Austria staying ten years or more in Austria 2012-2020 and naturalisations in Austria, 2012-2020

Table 12.1. Descriptive statistics for the variables of the regression analyses

Table 12.2. Logistic regressions: effects of citizenship on being employed and on gender role attitudes

Table 12.3. Linear regressions: the effects of citizenship on social contacts with Austrians, attitudes toward interethnic marriages, German-language skills, the sense of national belonging and interest in events in Austria

Table 12.4. Average integration differences according to immigrants' migration background, citizenship status and length of stay in Austria (means)

Table 13.1. Distribution of all Austrians abroad and respondents by country or world region (in \%) 
Table 13.2. Respondents' attitudes towards (dual) citizenship (in \%)

Table 13.3. Logistic regression on determinants of the attitude towards dual citizenship Table 13.4. Willingness to accept the citizenship of the host country by duration of stay in the host country, highest level of education, sex, age and region of residence, $\mathrm{n}=2,152-2,187$ (\%)

Table 13.5. Enquiries made by respondents about (dual) citizenship, $n=2,403$ (\%)

Table 14.1. First and second ethnic-national affiliation by language group (sum of percentages)

Table 14.2. Frequencies of second ethnic-territorial affiliations conditioned by first affiliation, percentages per row (only for the most frequent categories)

Table 14.3. Multivariate analysis of the social determinants of attitudes towards dual citizenship (ordinal logistic regressions)

\section{List of Figures}

Figure 5.1. Regions by percentage of countries that permitted dual citizenship in 1990, 2016

Figure 5.2. World map divided into citizenship tiers

Figure 6.1. Number of persons acquiring Dutch citizenship by naturalisation or through option declaration, 1990-2018

Figure 6.2. Stepwise overview of the criteria by which the moment of eligibility for naturalisation is determined

Figure 6.3. Immigrant cohorts 1985-1997, by dual citizenship regulation of country of origin (in percentages)

Figure 6.4. Heterogenous effects of the impact of losing or having to renounce the original citizenship on naturalisation rates among immigrants across different subsamples. Dots denote point estimates, and horizontal lines correspond to $95 \%$ confidence intervals.

Figure 6.5. Hazard ratio dual citizenship acceptance on immigrant naturalisation propensity (reference category = immigrant loses or has to renounce origin citizenship) by years since migration

Figure 6.6. Hazard ratio dual citizenship acceptance on immigrant naturalisation propensity (reference category = immigrant loses or has to renounce origin citizenship), by years since migration, for immigrants from EU/non-EU (left graph) and high-/low-HDI (right graph) countries of origin

Figure 8.1. Acquisition of Danish citizenship, numbers per year

Figure 8.2. Acquisition of Danish citizenship, share per year by region of origin

Figure 11.1. Share of foreign citizens (among them, non-EU/EFTA citizens) in Austria on $1 / 1 / 2020$ by federal province and length of registered stay (\%)

Figure 11.2. Evolution of foreign population in AT 2012-2020 by selected citizenship and length of stay 
Figure 11.3. Evolution of share of foreign population in AT 2012-2020 by length of stay (\%)

Figure 13.1. Importance of citizenship by age, duration of stay in host country and highest level of education (in \%)

Figure 13.2. Importance of citizenship by region of residence, $n=2,390$ (in \%)

Figure 13.3. Percentage of participants who responded "Strongly agree" to the statement "Austrians who have been living abroad for some time should be given easier access to dual citizenship" ( $n=2,381)$

Figure 13.4. Share of respondents with a very positive view on dual citizenship by duration of stay in the host country (in \%)

Figure 13.5. Reasons for acquiring the foreign citizenship (in \%)

Figure 14.1. Attitudes towards different aspects of citizenship

Figure 14.2. The various forms of relationship of South Tyroleans to Austria

Figure 14.3. Opinions on a special autonomy for South Tyrol

Figure 14.4. Advantages of an additional Austrian citizenship 



\section{Preface}

This volume argues that the toleration of dual citizenship has become a new global norm. It explores the drivers of this shift in state attitudes and its consequences at a global level and also compares the situation in several European countries. Yet some states are bucking the trend. Among these is Austria, whose citizenship policies have been marked by an increasingly restrictive access to naturalisation, the absence of birthright citizenship for those of the second generation born to immigrant parents and a reluctance to tolerate dual citizenship for both immigrants and emigrants. The final section of this book provides an in-depth examination of this curious case of "The dog that didn't bark" and suggests pathways for future reform.

As with any serious scientific work, this book could not have been produced without the support of several institutions and many persons. First of all, we have to mention the Austrian Academy of Sciences, which offers a unique platform for interdisciplinary scientific work for junior, mid-career and senior scientists. Apart from its own 28 research institutes, which employ around 1,700 researchers across a broad spectrum of scientific disciplines, it also includes Scientific Commissions. These consist of both active and retired scholars from several Austrian universities who are willing to collaborate across institutes and disciplines in a specific research field. The aim of the Commission for Migration and Integration Research (KMI) is to provide a platform for migration research in Austria, to carry out its own projects and to disseminate their findings to the wider public. This book is the result of a project hosted by KMI.

The original idea for the project emerged after the 2017 Austrian government manifesto proposed to offer Austrian citizenship to German- and Ladin-speaking South Tyroleans in addition to their Italian one. The second editor of this volume, who is himself both an Italian and an Austrian citizen, felt that this offer of extraterritorial Austrian citizenship might cause a serious problem for the peaceful coexistence of the German speaking with the Italian language group in South Tyrol, which comprises about a fourth of the province's population. Therefore, he proposed to carry out a representative survey among all three language groups on their ideas and intentions in relation to such a proposal. In the elaboration of the survey questions and methods, he was assisted by Francesco Palermo (Eurac Research, Bozen/Bolzano and the University of Verona), Hermann Atz (apollis Institute of Social Research and Opinion Polling, Bolzano/Bozen) and Günther Pallaver (University of Innsbruck and President of Michael Gaismair-Gesellschaft, Bolzano/Bozen). This survey was carried out in spring 2019 and we are grateful to several private sponsors for contributing to the financing of it.

The first editor of this volume is an Austrian citizen who had just returned from Italy after eleven years of teaching and building GLOBALCIT, an online global citizenship observatory at the European University Institute in Florence and had been elected Chair of the KMI. The two editors quickly agreed to join forces and expertise. The plan was to 
extend the scope of the research to two other groups whose interest in dual citizenship was much more strongly articulated than in South Tyrol: immigrants in Austria who do not have Austrian citizenship and emigrants from Austria who have kept their citizenship of origin and might be interested in acquiring that of their host country.

The former group amounts to as many as 1.4 million people - about 15 per cent of the whole Austrian population. When it comes to the granting of citizenship and, in particular, the toleration of dual citizenship, Austria follows a much more restrictive policy than other comparable European countries. After many unsuccessful attempts to get funding for such a survey, the provincial governments of Upper Austria and of Vienna agreed to finance surveys among immigrants without Austrian citizenship to find out about their perceptions, attitudes and intentions with regard to naturalisation. These surveys will be carried out in spring 2021 more or less simultaneously with the publication of the present volume, so their results cannot yet be reported. However, this volume includes three contributions which investigate specific aspects of immigrant naturalisation in Austria - Rainer Bauböck and Gerd Valchars analyse Austria's rejection of dual citizenship, Stephan Marik-Lebeck from Statistics Austria examines how many non-Austrian citizens fulfill the residence requirement for attaining Austrian citizenship and Raimund Haindorfer and Max Haller compare immigrants with and without Austrian citizenship in order to see whether naturalisation fosters integration.

Our efforts to investigate the demand for dual citizenship among Austrian expats were successful at the earlier stage of the project. We contacted the World Association of Austrians Living Abroad (Auslandsösterreicher Weltbund or AÖWB), which has promoted the toleration of dual citizenship for its Austrian expatriates for many years and was very interested to know more about the attitudes of Austrians living abroad (all in all about half a million). We are very grateful to the AÖWB's President Jügen Em, the President of the Austrian Club London - Jürgen Bischof - and the General Secretary Irmgard Helperstorfer for carrying out a quite comprehensive online survey on this topic among AÖWB members in autumn 2019. The results of this survey are analysed in the contribution by Florian Gundl to this volume.

As a corollary to these empirical studies, we convened an international symposium on the topic of dual citizenship, which took place in Vienna on 19 December 2019. Some of the top experts on dual citizenship from half a dozen countries around the world presented papers. The symposium also included a roundtable, with policy-makers focusing on Austrian policies. The publication yield of this event was excellent, since most of the papers presented there are included in this volume. We are grateful to Hanneke Friedl, who assisted us in preparing the conference, to all the participants and to the contributors to this volume.

For enabling us to carry out this symposium and the publication of this book we are, firstly, grateful to the Austrian Academy of Science. We would like to thank, in particular, the President of the Division of Humanities and Social Sciences, Oliver Jens Schmitt, for 
his encouragement and budgetary support for the book's publication. In addition, we are grateful to Wiebke Sievers, who has been coordinating the KMI for many years and who provided invaluable advice on the administration of the project and the book publication. The manuscript was thoroughly assessed by two anonymous international reviewers. We are grateful for their constructive comments - which helped the authors to improve their chapters - and for their enthusiastic endorsement of the book. Our proof editor, Jenny Money, engaged thoroughly with the draft manuscripts through several rounds of revisions and corrections. Thanks also go to the Austrian Academy of Sciences Press, its directors - Thomas Jenztsch and Herwig Stöger - and Robert Püringer, who was in charge of this publication. Publishing this volume as an open access book in addition to the print edition is a great opportunity to disseminate the research gathered in these pages and also a novel experience for the Austrian Academy of Sciences Press.

Vienna, January 2021

Rainer Bauböck and Max Haller 



\title{
Chapter 1
}

\section{Introduction}

\author{
Max Haller, Professor Emeritus, Department of Sociology, University of Graz/ \\ Austrian Academy of Sciences, Vienna \\ Rainer Bauböck, European University Institute, Florence/ \\ Austrian Academy of Sciences, Vienna
}

Citizenship is a multi-faceted concept. It is often understood to refer to a legal status - which, in international law, is called nationality - and a bundle of legal rights and duties associated with the status. This legal-institutional conception of citizenship can be juxtaposed with a sociological one that regards citizenship as connected to living conditions, a collective identity and a set of social practices. This book focuses mostly on the former interpretation of citizenship although it also takes into account individuals' attitudes towards the institution of citizenship and their motivations for changing their citizenship status and exercising their rights.

As a legal institution, citizenship serves two different functions - an external and an internal one. Externally, citizenship allocates individuals to states in the international state system (Brubaker 1992) and creates a basic responsibility of states for the protection of individuals' rights. These include the right to return to one's own country and the right of states to exercise diplomatic protection when their citizens' rights are violated by another state. The allocation of citizens to states is, however, not a perfect one. An estimated 4.2 million persons are stateless and thus without any recognised citizenship status (UNHCR 2020). There is also an unknown but rapidly increasing - and certainly much larger - number of individuals who hold more than one citizenship. This volume thus puts specific emphasis on the proliferating phenomenon of dual citizenship.

Connected with globalisation and changes in the relations between states, a new worldwide trend can be observed towards access to citizenship status and rights for both immigrants and emigrants and an increasing toleration of dual citizenship. These trends have been interpreted as manifestations of post- or transnational citizenship (Bauböck 1994; Blatter, Sochin D'Elia and Buess 2018; Faist 2008; Joppke 2010a; Sassen 2002; Soysal 1994; Spiro 2016). These two frames are not identical: a postnational one regards citizenship as increasingly disconnected from membership in nation states, whereas a transnational one focuses on interactions and overlap between statuses and rights generated by states interlinked in citizenship constellations (Bauböck 2010). Important questions investigated include the problem of dual loyalty (Baron 2009), the connection between naturalisations and socioeconomic integration (DeVoretz and Bevelander 2009; Hainmueller and Hangartner 2017; OECD 2011); and the social meaning of citizenship rights 
and obligations from the perspective of both nation states and individuals (Janowitz 1980; Turner 1990; Vink 2015). Some authors have pointed out that global transformations involve a change in the meaning and value of citizenship, which tends to be regarded ever more instrumentally by both states and individuals (Bauböck 2019; Harpaz 2019; Harpaz and Mateos 2018; Joppke 2010b).

The external and internal functions of citizenship can be disconnected to a significant extent. All contemporary states have laws that determine who their nationals are and expect all other states to recognise such an attribution of membership. In a minimalistic interpretation, nearly all contemporary states also derive their internal legitimacy from "the people" subjected to their rule - i.e., the collective of their citizens - rather than from divine authority or the powers derived from territorial conquest. However, the internal function of citizenship as membership in a self-governing political community is fully developed only in democratic states whose legislatures represent citizens and whose governments are accountable to them. At the latest since the French Revolution, the state no longer belongs to the monarch and the feudal elites but must include and represent its citizens. The main conceptual instrument for achieving this breakthrough was citizenship. It implied the status of membership in a state associated with full social and political rights, based on the revolutionary ideas of freedom, equality and fraternity (Kadelbach 2007). The precise content of citizenship has evolved over time and varied across democratic states. T. H. Marshall's (1950) evolutionary narrative of eighteenth-century civil rights in England generating political rights in the nineteenth century and these, in turn, leading to social citizenship in the twentieth, cannot be generalised to other contexts. For example, in late-nineteenth-century Germany, social rights preceded political ones and were introduced top-down to buy off working-class discontent (Mann 1987). It is also often argued that, today, only social citizenship rights are still incomplete in liberal democracies, while civil and political rights have universal coverage and are fully implemented. This is quite obviously a misperception. New developments, such as the digital revolution, have called for the reassessment of the content of civil rights such as that to privacy and global challenges - such as the Covid-19 pandemic and the climate crisis - raise new questions about citizenship rights. Most importantly for the topic of our book, Marshall's (1950) account of citizenship is an exclusively internal one that ignores its role in the international state system and specifically how international migration can undermine his implicit assumption of national homogeneity and universal inclusion of the resident population as citizens (Joppke 2010b). What we find instead are increasing numbers of non-citizen residents, most of whom enjoy some types of right (civil and social but not full political rights) while the rights of non-resident citizens are being strengthened by granting them opportunities to vote from abroad in national elections (Arrighi and Bauböck 2017).

There is also a significant tension between the internal and external functions of citizenship. The latter has been described as an instrument for preserving global inequality (Carens 1987; Milanović 2016). Seen from a global perspective, the "birthright lottery" 
(Shachar 2009) seems deeply unjust, as the citizenship which individuals receive automatically at birth determines not only what opportunities they will enjoy in their home country but also which other states will be ready to admit them if they seek to improve their lives through migration. From a democratic perspective, however, citizenship is always linked to norms of individual equality and the promotion of the common good within a particular political community. The set of universal human rights in international law and their enforcement mechanisms are not strong enough to bridge this gap between aspirations of domestic and of global equality that is inherent to citizenship as a normative concept. Narrowing this gap will require not just individual rights but policies of resource transfers and the promotion of endogenous democratic transformation and economic development in the "Global South".

The recent evolution of citizenship as a status and bundle of rights has been characterised by two major changes. First, the technological revolutions in transport and travel and in electronic communication have, in some regards, produced a "world society" (Luhmann 1975). They have induced mass mobility across international borders on a scale never seen before in human history. While international migration - measured as the longer-term settlement of persons in states other than their country of birth - still remains at the rather modest level of 272 million people or 3.5 per cent of the global population (IOM 2020), international border crossings have grown steeply from just 25 million tourist arrivals in 1950 to 1.4 billion by 2018 (UNWTO 2019). Enhanced global mobility has also changed the character of migration in general: many people moving to another country today do so only for a limited time, returning back to their home country or proceeding on to another one (de Haas, Castles and Miller 2020; Haller 2019; Manning 2005).

Second, citizenship has not only become partly deterritorialised but has also moved up to supranational levels. Regional unions of states have introduced distinct forms of citizenship associated with free movement and political representation in Europe, Latin America and Western Africa. The most advanced example is the European Union, which can be characterised as a new type of polity composed of independent as well as interdependent states. Already the 1957 Treaty of Rome, which created the European Economic Community, included the free movement of workers as one of its four fundamental freedoms. The 1992 Treaty of Maastricht, which established the European Union, introduced a formal citizenship of the Union that comes with generalised rights to free movement, non-discrimination on the grounds of nationality in other member states and political participation rights at local and European levels. Since the 1985 Treaty of Schengen, most member states of the European Union and some non-EU countries decided to abolish border controls within their joint territory. This development can be considered as a change towards more freedom and openness in Europe, although it also has its drawbacks. First, growing numbers of internal migrants within the European Union have few incentives to acquire the citizenship of their new country of residence and remain excluded from national voting rights there. Second, opening internal borders 
for free movement has made it necessary to coordinate and strengthen controls at the EU's external borders, making it more difficult for people from outside Europe to get in (Carr 2015; Haller 2016).

\section{Structure of the book and overview of the chapters}

The volume combines three perspectives on (dual) citizenship. It takes a bird's eye view of global trends and patterns, it examines more closely a range of cases in order to sharpen a comparative view and it goes into even more detail with regard to the peculiar case of Austria, whose citizenship laws and policies raise important conundrums. This process of "zooming in" will hopefully help readers to put the Austrian case into a broader perspective that has not been present in public debates about citizenship there. What emerges from a comparative perspective is that Austria represents a case of high immigration with high barriers to citizenship. The strong resistance against the global trend towards the toleration of dual citizenship (see Chapter 3) presents a particular puzzle that will be addressed in Chapter 10.

A second feature of the book is its interdisciplinary approach. As citizenship is a legal status determined under national law that is constrained by international legal norms, legal analysis is an indispensable starting point. Political science is needed to understand the drivers and actors of citizenship policies, the impact of inclusive or exclusionary citizenship on democratic politics and the importance of domestic political systems and international processes of norm diffusion for explaining divergent trajectories and regional trends. Equally important is the sociological perspective, which investigates the actual relevance of citizenship for the life situations of migrants or ethnic-kin minorities, as well as the attitudes of these immediately affected groups and of the general population towards the granting of new citizenships.

\section{Section 1: Citizenship identity and ulitily in global perspective}

The relation of citizenship to social and national identity is discussed in Chapter 2 by Max Haller. In modern societies, many people belong to several different social circles. This contributes to their particular identity although it may also require considerable effort to develop a coherent personality. A complex, multiple identity - including particular gender, familial, occupational, religious, ethnic and other identities - is a characteristic of many people today. National identity is one among these. In particular, those people may become aware of it who are moving from one country to another or who are born to immigrant parents. Migrants will feel close to their countries of both origin and destination and therefore will have an interest in dual citizenship. However, interest in citizenship also has an instrumental value: it provides the rights of a full citizen and the new passport might open access to many more states around the world than that of the country of origin. In order to test these hypotheses, the chapter presents data from 
several surveys. Findings from the International Social Survey Programme (ISSP) show that people consider citizenship to be one of the most important characteristics of national identity. A study on immigrants in Austria from the former Yugoslavia and from Turkey confirms, as mentioned above, that most of them feel connected to their countries of both origin and destination. The chapter also discusses citizenship as a set of obligations, particularly concerning political participation. Here, the ISSP data clearly show that the general population also thinks in this way. A large majority considers participation in elections and paying taxes as basic duties of citizens. Even conscription is considered as important by half of the population in many countries.

In Chapter 3, Rainer Bauböck summarises the causes of the strong global trend towards the toleration of dual citizenship. He then focuses on the possible limits of dual citizenship and the reasons for resistance to it by some states. Bauböck specifically considers why the two largest states in terms of population - China and India - adhere to a policy of strict non-toleration of multiple citizenship out of security concerns and adversarial ideologies of national sovereignty. He also examines the Eastern European context, where policies of regional hegemony (by Russia) and the mobilisation of ethnic-kin minorities in the near-abroad for buttressing the domestic hegemony of political incumbents (in Hungary) have triggered counter-reactions against dual citizenship in neighbouring states. In so-called Western democracies, security concerns about terrorism have not led to a retreat from dual citizenship but have turned a second citizenship into a potential liability, as possessing it allows states to denationalise citizens whom they consider to be a threat. Finally, Bauböck considers whether the demand for and supply of dual citizenship might shrink if the hyperglobalisation dynamics since the 1990s were partly reversed in response to pandemics and the climate crisis.

In Chapter 4, Peter Spiro takes up the latter question from a long-term historical perspective. After analysing the period of global resistance against multiple nationality from the mid-nineteenth to the mid-twentieth century, he shows why the underlying concerns have gradually faded away in an increasingly interconnected state system. Spiro's other focus is on the changing meaning and value of citizenship for individuals in the context of globalisation. Picking up the topic of Haller's Chapter 2, Spiro argues that the rise of dual citizenship is ultimately due to a slow tectonic change in the nature of national identities, as constructed by states and experienced by individuals. The novel contribution of the chapter lies in Spiro's reflections on the future of dual citizenship in a post-Covid-19 world. He argues that states will not be inclined to reverse citizenship offers to extraterritorial groups - such as foreign investors and populations linked to the country through more distant lines of ancestry - as long as they receive benefits from them that might help them to cope better with the shocks of the economic crisis. At the same time, individual demand for additional passports of certain countries is likely to increase if these do not only serve to enhance geographic mobility or social prestige but also provide a kind of global health insurance in case of pandemics. 
Yossi Harpaz' Chapter 5 builds on his recent book Citizenship 2.0 (Harpaz 2019). It provides an empirical analysis of the global toleration of dual citizenship and examines its strategic uses by governments and individuals in a context of global inequality. Harpaz finds a steep rise - from 28 per cent in 1990 to 75 per cent in 2016 - in the number of states that accept dual citizenship in cases of the voluntary acquisition of a foreign nationality or of the acquisition of the country's own citizenship by naturalisation. Through offering a second citizenship, states aim to include international migrants, extraterritorial populations linked to a country of origin through ancestry or ethnicity and global investors. The benefits that states hope to accrue through these policies include symbolic, demographic, electoral or economic values. On the demand side, the chapter argues that global inequality explains patterns in the acquisition and use of dual citizenship. Harpaz categorises states into first, second and third tiers according to the value of their citizenship for individuals. He demonstrates that demand for an additional first-tier citizenship is highest in second-tier countries, which include most of Latin America and Eastern Europe as well as Israel. Case studies in Mexico, Serbia and Israel reveal three main motivations for obtaining a second passport: enhanced mobility, the signaling of social status and the mitigation of risks associated with a current residence and citizenship.

\section{Section 2: Dual citizenship in comparative perspective}

The second section of the book discusses European cases that illustrate different motivations for states to accept or promote dual citizenship as well as the impact that this option has on immigrants' motivations to acquire the citizenship of their host country.

In Chapter 6, Floris Peters and Maarten Vink address the latter question based on the quantitative analysis of Dutch data on naturalisation. The Netherlands presents a somewhat unique case where dual citizenship for immigrants was tolerated for several years in the 1990s before again becoming restricted. Peters and Vink use individual-level register data and apply a Cox proportional hazards regression to analyse naturalisation propensity among immigrants who could naturalise with or without dual citizenship. The opportunity to retain a previous citizenship in naturalisation procedures depends on both the country of origin and the host country accepting such an outcome. Peters and Vink therefore combine information about the changing regulation in the Netherlands with information on the origin-country toleration of expatriate dual citizenship rules around the world. They find that the opportunity to hold dual citizenship significantly raises the propensity of immigrants to naturalise - a higher incentive which remains strong for almost two decades after migration to the host country. A second important finding of this study is that the opportunity to retain a previous citizenship especially affects naturalisation rates among immigrants from the EU and highly developed third countries. This shows that migrants are particularly reluctant to renounce high-value citizenships. 
In highly developed countries of immigration, dual citizenship has been discussed mostly as a tool for immigrant integration; in migrant sending countries all over the world it is sen as a way to retain legal ties with emigrants. By contrast, Szabolcs Pogonyi's Chapter 7 shows how Eastern European states have used external dual-citizenship polices as instruments in the toolbox of postcommunist nation-building projects. In Eastern Europe, newly restored states as well as countries whose international borders have not been involved in recent territorial changes, offered citizenship for their ethnic kin living beyond the borders in order to strengthen the claims of the titular majorities over the state, creating or strengthening thereby ethnocratic regimes. Pogonyi provides an overview of kin-citizenship policies in Eastern Europe and argues that the inclusion of non-resident populations in the demos as part of fast-track nation-building generates internal democratic deficits and diplomatic skirmishes but rarely results in outright interstate conflict. The chapter also points out that individuals are mostly interested in kin-citizenship for reasons that have little to do with governments' transborder nationalist projects.

Chapter 8 by Eva Ersbøll provides a case study that focuses on the citizenship policy process. Denmark is a country that has only recently reformed its citizenship law to allow for dual citizenship. Eva Ersbøll analyses this change from a legal and political perspective. The chapter starts with a historical analysis of Denmark's stance on dual citizenship that shows how, in particular, other Nordic countries' reforms towards the toleration of dual citizenship at the beginning of the new millennium had a lasting impact on debates in Denmark. Ersbøll refutes claims in some of the comparative literature that a key argument for the adoption of the Danish reform was the securitisation of migration and citizenship and the fact that tolerating dual citizenship allows the revocation of the citizenship of terrorists without rendering them stateless. Denmark's policy reversal came at the end of a much longer process that involved prior changes in other Nordic countries and changes in the composition of the Danish government. A detailed account of policy initiatives and stances by different parties shows how resistance to the reform came from a national-conservative and anti-immigration party that provided parliamentary support for minority Liberal-Conservative governments. When an alternative government coalition, led by the Social Democrats, emerged in the 2011 elections, parliament embarked on a path to reform that was finally adopted in December 2014 and that came into force under a new Liberal government in 2015.

In a similar vein as the chapter on Denmark, in Chapter 9, Günther Pallaver and Guido Denicolò examine the case of Italy, with a focus on the evolution of its citizenship law. They show that initial hostility towards dual citizenship after the Risorgimento gave way to a desire to maintain links with the large diaspora of Italian emigrants already in the first basic citizenship law of 1912. Including Italians abroad as citizens across several generations was fully compatible with an ethno-cultural conception of national identity and has been a dominant concern ever since. Italy also permits the so-called italiani 
oriundi - i.e., persons of Italian ancestry living permanently abroad - to regain Italian citizenship if they can prove that none of their direct ancestors has explicitly renounced it. The second group of residents abroad for whom Italy promotes the restoration of citizenship are ethnic Italians in the neighbouring territories of Slovenia and Croatia, which belonged to Italy before the peace treaties after World War II. Unlike for the italiani oriundi, these latter groups must establish a certain familiarity with the Italian culture and language. The active promotion of dual citizenship for them puts Italy in an awkward position when protesting against plans to award Austrian citizenship to German-speakers in South Tyrol (see Chapter 14). The final category discussed in the chapter is non-Italian immigrants whose numbers have been growing substantially since the 1990s. Although dual citizenship is tolerated in residence-based naturalisations, these are comparatively rare. Initiatives by the centre-left to introduce moderate forms of ius soli or ius culturae (naturalisation based on years of schooling) for the second generation have not been successful thus far.

\section{Section 3: Austrian citizenship at home and abroad}

The third section discusses (dual) citizenship in Austria. This country is a particularly interesting case and, in some ways, also a paradigmatic one. First, it has one of the highest levels of immigration in Europe. In 2018, 1,385 million foreign citizens were living in Austria, which amounts to 15.7 per cent of the resident population. ${ }^{1}$ This is - with the exception of small countries whose large shares of foreign population can be explained by particular contextual reasons ${ }^{2}$ - the highest proportion within the European Union. Germany (11.7 per cent), the United Kingdom (9.7) and France (7.0) have considerably lower shares than Austria in this regard. Second, among comparable states, Austria is also quite unique in its particularly low naturalisation rates. They have been frozen at 7 out of 1,000 foreign residents acquiring Austrian citizenship per year since 2010. ${ }^{3}$ This low naturalisation rate and Austria's persistently hostile attitude towards dual citizenship, which creates a major disincentive for naturalisation, are surprising given that its trans-

1 Eurostat figures. Available at: https://ec.europa.eu/eurostat/statistics-explained/images/f/fd/ Ausl\%C3\%A4ndische_Bev\%C3\%B6lkerung_nach_Staatsangeh\%C3\%B6rigkeitsgruppe\%2C_1_ Januar_2018_FP2019-de.png (accessed 08 December 2020).

2 Luxembourg has an exceptionally high rate of 47.8 per cent foreigners because the Grand Duchy, with its large EU offices and branches of international corporations, offers tens of thousands of jobs for highly skilled people from nearby countries and because its main source of low-skilled labour migration since the 1960s is Portugal, which is an EU member state; Estonia has a high proportion (14.9 per cent) because of its ethnic Russian population; Malta (14.1) and Cyprus (17.3 per cent) are small island states with large diasporas that attract wealthy investors and retirement migrants.

3 See https://www.statistik.at/web_de/statistiken/menschen_und_gesellschaft/bevoelkerung/ einbuergerungen/index.html (accessed 08 December 2020). 
formation into an immigration country was already noted in the early 1990s (Fassmann and Münz 1995). To investigate the reasons for this discrepancy between demographic fact and collective identities, reflected both in Austrian politics and in the attitudes of the populations, is therefore of more general interest.

In Chapter 10, Rainer Bauböck and Gerd Valchars focus on Austria's rejection of dual citizenship. The chapter takes into account the history of citizenship and the international conventions that Austria has joined and presents a detailed analysis of those provisions in Austrian law that are relevant for dual citizenship. The authors find that Austria has accepted dual citizenship in the case of acquisition by birth but still clings to a general prohibition of dual citizenship in both the naturalisation of immigrants and when Austrians voluntarily acquire another citizenship. The chapter addresses the conundrum as to why Austria has resisted the global trend towards toleration, although none of the explanations for such resistance discussed by Bauböck in Chapter 3 apply to the Austrian case. It concludes that politicised hostility towards dual citizenship for one particular group of immigrants - those from Turkey - seems to have blocked debates about reform. The chapter ends with sketching pathways to policy change and a menu of legislative reforms that build on principles already recognised in Austrian citizenship legislation and that could lead to the toleration of dual citizenship.

Chapter 11, by Stephan Marik-Lebeck, examines - from a statistical perspective - the gap between Austria's demography as an immigration society and its low rates of citizenship acquisition. Marik-Lebeck asks how large the stock is of people among the country's resident foreign citizens who, in principle, would be entitled to apply for Austrian citizenship under the present legal conditions for its acquisition. The chapter first shows that Austria's naturalisation rates are, in fact, among the lowest in the EU (together with Denmark and the Czech Republic). Apart from the requirement to renounce a previous citizenship, the most important legal preconditions for naturalisation in Austria are a 10-year period of residence, sufficient income and proof of a sufficient knowledge of the German language. The chapter uses Central Residence Registration data to estimate the numbers of foreign residents potentially eligible for naturalisation. It takes into account information about duration of residence, age, citizenship of origin and region of residence in Austria and calculates how much the share of foreign residents in Austria could be reduced if EU/EFTA citizens and migrants from other countries who meet the age and residence requirements became Austrian citizens. The chapter concludes with a discussion of the reasons for the low uptake of citizenship. Among these are the weak incentives for EU citizens to apply for Austrian citizenship because this would not add significantly to their rights (except that of voting in national elections), the strict requirements that naturalisation applicants must have had a sufficient and steady income for several years and the restrictive Austrian law concerning dual citizenship.

A core assumption about naturalisation in the literature is that it supports the social, cultural and political integration of immigrants. There are several studies on this issue 
for other countries and, in Chapter 12, Raimund Haindorfer and Max Haller investigate this hypothesis for the case of Austria. They compare the integration outcomes of immigrants with and without Austrian citizenship, controlling for other relevant factors (such as the length of stay in Austria). Their analysis is not based on panel data but they investigate more aspects of integration than other studies have done thus far. They look at four aspects of (social) integration in particular: structural integration (employment), social integration (social contacts with Austrians and agreement to interethnic marriages), cultural integration (knowledge of German and overcoming traditional gender roles) and identificative integration (a sense of national belonging and an interest in Austrian events). Their multivariate statistical analysis of the data from a survey of immigrants from the former Yugoslavia and Turkey shows that naturalisation is correlated positively with integration on five out of seven indicators. No effect of naturalisation was found only for attitudes towards gender roles and an interest in Austrian affairs. Thus, their central hypothesis - that naturalisation will have a positive effect on integration outcomes in the host society - has been confirmed by their empirical findings. It is noteworthy that the literature on this phenomenon has examined whether there might be a reciprocal relation between naturalisation and integration - with well-integrated immigrants applying more frequently for naturalisation; however, in a recent study, an experimental research design has demonstrated that naturalisation itself has a causal effect as it is a catalyst for further integration (Hainmueller and Hangartner 2017).

Another group of people connected to Austria who might be interested in dual citizenship are Austrians living abroad. This is a considerable population, estimated at 580,000 persons - more than the inhabitants of some Austrian provinces. They are represented by Austrian Associations all over the world, which are coordinated by the World Association of Austrians Living Abroad (AÖWB). This latter association has carried out a mail survey among its 10,000 members in the design of which the editors of the present volume were involved. About 2,400 persons participated in the survey. They were asked about their attitudes towards the relevance of citizenship in general, towards attaining the citizenship of the country where they are living and towards dual citizenship. The results, which are presented in Chapter 13 by Florian Gundl, are unambiguous. Nearly all respondents consider citizenship in general and Austrian citizenship in particular to be very important. A large majority supports dual citizenship and many would be interested to acquire the citizenship of their country of residence. This is much more frequently the case for Austrian expatriates living in advanced Western nations in Europe and North America and much less so for those living in Asia, Africa and South America. This finding confirms the analysis by Harpaz in Chapter 5 and by Peters and Vink in Chapter 6 that interest in dual citizenship strongly depends on the perceived value of particular nationalities. Interest in dual citizenship is also more pronounced among those with a longer term of residence in their host country and for persons with 
higher levels of education. Since the sample was somewhat biased toward this group, the survey results might overestimate, to some degree, the interest in dual citizenship among Austrian expatriates.

Dual citizenship policies sometimes aim to include not only migrants but also co-ethnic groups in neighbouring countries. As analysed by Szabolcs Pogonyi in Chapter 7, this has been the case for several countries of Central Eastern Europe. In recent years, some political actors in South Tyrol and Austrian governments have proposed the idea of offering Austrian citizenship to German-speaking South Tyroleans in addition to their Italian one. The historical background for this offer was that some right-wing groups and political parties in Austria and in South Tyrol are uneasy with the political autonomy granted to the region by Italy, in spite of the fact that it assures cultural autonomy, a high level of self-government to the province and a quite peaceful coexistence between the German- and the Italian-language groups. In order to grasp the attitudes of South Tyroleans of both groups, a representative survey was carried out, asking about their interest in Austrian citizenship. The results were surprising even to the initiators of the survey and the authors of this volume's Chapter 14, Max Haller and Hermann Atz. A large majority of the respondents were quite critical about this proposal, not only among the Italian-speakers but also among the intended beneficiaries - i.e., German-speaking South Tyroleans. Their rationale was that the exclusive conferral of Austrian citizenship to the German-speaking group would drive a wedge between the German- and Italian-speaking population. Most South Tyroleans identify both with their province and with Italy and they also maintain diversified contacts with Austria. However, only a minority thinks that the conferral of Austrian citizenship would contribute to an improvement in their relations with Austria. Thus, the conclusion from this study is clear: dual citizenship can be a very important asset for people affiliated, in social, economic and cultural terms, to two countries but, when bestowed upon ethnic-kin minorities, it could also become more of a disruptive than an integrative force.

\section{References}

Arrighi, J.-T. and Bauböck, R. 2017. A multilevel puzzle: migrants' voting rights in national and local elections, European Journal of Political Research, 56(3): 619-639.

Baron, I.Z. 2009. The problem of dual loyalty, Canadian Journal of Political Science, 42(4): 1025-1044.

Bauböck, R. 1994. Transnational Citizenship. Membership and Rights in International Migration. Cheltenham: Edward Elgar.

Bauböck, R. 2010. Studying citizenship constellations, Journal of Ethnic and Migration Studies, 36(5): 847-859.

Bauböck, R. 2019. Genuine links and useful passports: evaluating strategic uses of citizenship, Journal of Ethnic and Migration Studies, 45(6): 1015-1026. 
Blatter, J., Sochin D'Elia, M. and Buess, M. 2018). Bürgerschaft und Demokratie. BernWabern: Eidgenössische Migrationskommission EMK.

Brubaker, R.W. 1992. Citizenship and Nationhood in France and Germany. Cambridge, MA: Harvard University Press.

Carens, J.H. 1987. Aliens and citizens: the case for open borders, The Review of Politics, 49(2): 251-273.

Carr, M. 2015. Fortress Europe. Inside the War Against Migration. London: C. Hurst

De Haas, H., Castles, S. and Miller, M.J. 2020. The Age of Migration. New York: Guilford Press (6th edition).

DeVoretz, D.J. and Bevelander, P. (eds) 2009. The Economics of Citizenship. Malmö: Malmö Högskola.

Faist, T. 2008. Dual Citizenship in an Age of Mobility. Washington, DC: Migration Policy Institute.

Fassmann, H. and Münz, R. 1995. Einwanderungsland Österreich? Historische Migrationsmuster, aktuelle Trends und politische Maßnahmen. Vienna: Jugend \& Volk.

Hainmueller, J. and Hangartner, D. 2017. Catalyst or crown: does naturalization promote the long-term social integration of immigrants? American Political Science Review, 111(2): 256-276.

Haller, M. 2016. Why empires build walls: the new iron curtain between Africa and Europe, in Gasparini, E. (ed.) The Walls between Conflict and Peace. Leiden and Boston: Brill, 98-125.

Haller, M. 2019. Migration und Integration: Fakten oder Mythen? Siebzehn Schlagwörter auf dem Prüfstand. Vienna: Verlag der Österreichischen Akademie der Wissenschaften.

Harpaz, Y. 2019. Citizenship 2.0. Dual Nationality as a Global Asset. Princeton: Princeton University Press.

Harpaz, Y. and Mateos, P. 2018. Strategic citizenship: negotiating membership in the age of dual nationality, Journal of Ethnic and Migration Studies, 45(6): 843-857.

IOM 2020. World Migration Report. Geneva: International Organization for Migration.

Janowitz, M. 1980. Observations on the sociology of citizenship: obligations and rights, Social Forces, 59(1): 1-24.

Joppke, C. 2010a. Citizenship and Immigration. Cambridge: Polity Press.

Joppke, C. 2010b. The inevitable lightening of citizenship, European Journal of Sociology/ Archives européennes de sociologie, 51(1): 9-32.

Kadelbach, S. 2007. Citizenship rights in Europe, in Ehlers, D. (ed.) European Fundamental Rights and Freedoms. Berlin: de Gruyter, 547-548.

Luhmann, N. 1975. Die Weltgesellschaft, in Luhmann, N. (ed.) Soziologische Aufklärung 2. Opladen: Westdeutscher Verlag, 51-57.

Mann, M. 1987. Ruling class strategies and citizenship, Sociology, 21(3): 339-354.

Manning, P. 2005. Migration in World History. London and New York: Routledge.

Marshall, T.H. 1950. Citizenship and Social Class and Other Essays. Cambridge: Cambridge University Press. 
Milanović, B. 2016. Global Inequality. A New Approach for the Age of Globalization. Cambridge, MA: Harvard University Press.

OECD (2011). Naturalisation: A passport for the better integration of immigrants? Paris, OECD Publishing.

Sassen, S. 2002. Towards post-national and denationalized citizenship, in Isin, E.F. and Turner, B.S. (eds) Handbook of Citizen Studies, New York: Sage, 277-291.

Shachar, A. 2009. The Birthright Lottery. Citizenship and Global Inequality. Cambridge, MA: Harvard University Press.

Soysal, Y. 1994. Limits of Citizenship. Migrants and Postnational Membership in Europe. Chicago, University of Chicago Press.

Spiro, P.J. 2016. At Home in Two Countries. The Past and Future of Dual Citizenship. New York: New York University Press.

Turner, B.S. 1990. Outline of a theory of citizenship, Sociology, 24(2): 189-217.

UNHCR 2020. Global Report 2019. Geneva: United Nations Refugee Agency.

UNWTO 2019. International Arrivals by World Region. Available at: https://ourworldindata. org/tourism\#international-arrivals-by-world-region (accessed 09 December 2020).

Vink, M. 2015. Elusive Citizenship. Maastricht: Maastricht University, Inaugural Lecture. Available at: https://doi.org/10.26481/spe.20150501 mv (accessed 09 December 2020). 



\section{Citizenship and Utility in Global Perspective}





\title{
Chapter 2
}

\section{(Dual) Citizenship and National Identity in a Globalised World: Sociological Perspectives}

\author{
Max Haller, Prof. Emeritus in Sociology at Karl-Franzens University, Graz and \\ Chair of the Vienna Association of Sociology
}

\begin{abstract}
This paper starts from the concept of identity to develop some hypotheses about the attitudes of people toward national identity and citizenship. It is proposed that there are two factors which determine these attitudes: an evaluative-normative component related to the symbolic value of citizenship and a strategic orientation which considers the advantages connected with a particular passport. Empirical findings from the International Social Survey Program (ISSP) on National Identity and Citizenship are presented. It is shown that citizenship is a very important component of national identity in the eyes of the public and migrants usually exhibit a dual identity toward their countries of origin and destination. The surprisingly low naturalisation rates among immigrants in Western societies are also explained by two general factors: people do not want to lose their original national attachments; however, they also consider the instrumental advantages from acquiring the citizenship of the new country. Two further issues are discussed: the need for well-functioning democracies to have active citizens and the obligations connected with citizenship - of which these three are the most relevant: taking part in voting, paying taxes and, for men, performing military service. In the concluding section, the chapter points to the need to facilitate naturalisation, extend options of dual citizenship and improve the situation of denizens. Citizenship is a topic investigated mainly by scholars of public law and political scientists (Bauböck 1994; Hammar 1990; Spiro 2016). A number of sociologists have also contributed to this discussion (Brubaker 1992, 2010; Joppke 2010; Soysal 1994). In fact, sociology can contribute not only to the social aspects of citizenship but also to the discussion of the emergence and social impact of legal principles. At least since the writings of the Austrian legal scholar Eugen Ehrlich (1862-1922), we know that the legal reality of a community cannot be captured by looking only at formal written law because it also includes local and regional norms and customs and has a cultural and political character (Cotterell 1992; Ehrlich 1989 [1913]; Rehbinder 2014). In this chapter, I discuss three issues: first, the relevance of citizenship for personal, social and political identity in the modern world; second, some empirical data on the relevance and meaning of citizenship, as people in about 40 countries from all continents see it; and, third, three additional aspects of citizenship relevant from a sociological perspective. In the conclusions, the findings are summarised and some
\end{abstract}


normative conclusions drawn concerning the policies of naturalisation and the issue of dual citizenship.

\section{Citizenship, national and other identities}

In order to understand the relevance of citizenship for people from a sociological perspective, the concept of identity is a useful starting point. Identity is a term which was only introduced in psychology and the social sciences in the second half of the twentieth century but which has gained widespread acceptance since then.

\subsection{The concept of identity}

Among the pioneers of the concept was the German-American psychoanalyst Erik $\mathrm{H}$. Erikson (1902-1994). In one of his first books, Childhood and Society (1950) he developed the basic concept of identity, its development over the life course and its societal determinants. A sociological precursor of modern identity theory was the German sociologist Georg Simmel (1858-1918) who was also a Jew and was only appointed late in life as a university professor. In his 2013[1908] essay about the "criss-crossing of social circles", Simmel argued that a central characteristic of modern men is the fact that they belong to many different social circles which - in contrast to the concentric circles in traditional societies - only overlap partly. Since most of these circles are selected freely and each person exhibits a unique configuration of social roles, men and women become more distinct personalities and have more freedom to pursue specific lines of activity in different spheres of life. A third early founder of modern identity theory was the American George H. Mead (1863-1931). Influenced by pragmatist philosophers, he proposed that every human develops an identity through close interaction with others by taking over their roles, their use of symbols and, most importantly, their language. The formation of identity is an ongoing process, continuing into adulthood through interaction with others and the social and cultural context in which a person lives (Mead 1967[1934]).

Building on the insights of these pioneers and on contemporary identity literature (Abels 2006; Fukuyama 2018; Haller 2003, 569-572; Stets and Burke 2000; Tajfel 1978; Taylor 1989; Weigert, Teitge and Teitge 1986), the basic assumptions of identity theory can be summarised in five points:

- Identity is a more or less comprehensive and coherent self-image which determines our thinking and actions. This image includes knowledge, assumptions and beliefs about oneself, about others and about society and the world. A person with a clear identity feels more secure and self-conscious and will be better able to make important and timely decisions.

- A distinction has to be made between personal identity and social identity. The first includes all those "internal" aspects of identity which only the individual personally 
knows and may not disclose to others; social identity or "self" includes the obligations that a person has in different social sectors and institutions (family life, place of residence, work roles etc.) and the attributions which they experience from others, especially from those in their reference groups. Most important are those reference persons and groups with which someone is the most in contact and those personal roles in which he or she has the most autonomy of decision.

- Identity also includes emotional and evaluative-normative elements. Strong basic social emotions, such as pride and shame, are connected with specific actions and indicate for us the relevance of social events, reference persons and the social units in which we live. Evaluations and ethical-moral principles indicate the right and wrong ways of behaving and oblige us to act in certain ways while avoiding other lines of action. Emotions support values and value-based action. Empathy, for instance - the capacity to put oneself into the shoes of others - is the basis for altruism and moral behaviour.

- Identity is mainly formed during childhood and youth but continues to change and develop significantly over the life course. Such change is connected not only to the life-course transitions from childhood to youth, adulthood and old age but also to changes in the social and cultural context in which we live. One consequence of this is that identity must continually be re-defined to some degree. Another consequence is that, in modern societies, we must speak of multiple social identities, which include our roles as children or parents, as teachers, as work colleagues and as friends, etc. In different social contexts different identities are displayed.

- The concept of identity can also be applied to social groups and associations, organisations and nation states. The variation of the characteristics of the latter (level of development, size, political character) will significantly influence people's attachment to them.

The basic assumption of identity theory is that every person strives towards the development of a positive self-image; we associate preferentially with those others who confirm our positive self-image and tend to select jobs and pursue activities that support this positive self-image and to avoid actions and contexts which threaten it.

\subsection{National identity and citizenship}

Membership in a nation state and citizenship may constitute a significant element of identity. People living in one single country throughout their life may not be aware of this fact. However they, too, will be affected by "banal nationalism" (Billig 1995) in their everyday lives in many ways (for instance, by consuming mainly national mass media, being proud when their country wins in international sports competitions or preferring national over foreign products). National identity comes clearly to the fore when we travel to another country or when we meet a person who looks or speaks differently to us. We 
usually soon feel inclined to ask her or him "Where do you come from?" - meaning from which country (Peabody 1985). This happens frequently to immigrants even if they have lived in the country for many years or even decades. Many of them will feel embarrassed by this seemingly "innocent" question.

Let us try to deduce some research questions and hypotheses concerning this aspect of national identity and citizenship for migrants and others who do not possess the citizenship of the country in which they live.

- The level of awareness and self-reflexivity of national identity and citizenship may vary significantly between different groups of migrants and non-citizens. It will increase in line with the duration of residence in the new country and will probably be higher, more differentiated and more relevant for action among well-educated persons (Vordermeyer 2012).

- Migrants have three different reference groups (family members, neighbours, work colleagues and other contacts): those in the country of origin, the co-ethnic reference groups in the host country and the citizens of the host country. In the beginning of their stay in the host country, the first and second groups may be the strongest; later, the latter may gain in importance. Among persons with a migration background, identification with the country of origin will become weaker and often disappear altogether as a consequence of processes of assimilation (Esser 2009; Heckmann 2015).

- Membership in a nation state can be connected with strong emotional and evaluative elements. These are expressed in German terms such as Ortsverbundenheit (local attachment) or Vaterlandsliebe (literally "love of the fatherland" or patriotism). National membership can be associated with both pride and shame. Membership in a nation and citizenship also have normative implications, as expressed in John Kennedy's famous statement "Do not ask what your country can do for you but what you can do for your country". Compulsory military service was a significant obligation for male citizens in most nation states until recently, the duty to follow the laws of the state and to pay taxes are obligations of any resident in the territory and participation in elections is at least an implicit norm.

- Migration requires a significant re-definition of identity after arrival in another country. However, migrants will usually retain many elements of loyalty to their original identities and thus develop dual (or even multiple) national identities. The degree to which they acquire a new identity and potentially assimilate into the host society and culture will depend on many factors, including their migration motives and future mobility intentions and the size and concentration of co-ethnic communities in the host country. It will also vary according to the strength of their native identity and the difference between the cultures of the countries of origin and destination. 
- There are huge differences between nation states around the world in terms of size and internal social and cultural homogeneity or heterogeneity, as well as in terms of level of socio-economic development and wealth and of political systems. Therefore, personal national identity and an interest in acquiring the citizenship of a country will vary significantly according to the characteristics of the countries of origin and destination. Immigrants will identify more with well-developed, rich and democratic countries, as well as with large and powerful states, even if these engage in problematic internal and foreign policies.

National identity refers first and foremost to the realm of ideas, values, norms and emotions. However, the relation of women and men to citizenship will also be determined by instrumental considerations, based on a calculus of costs and benefits. Naturalisation is certainly connected with many tangible benefits - such as the right to unlimited residence and unconditional return, full access to the labour market and welfare assistance. The passport of most rich Western states opens the doors to most countries around the world. Thus, the decision to give up the citizenship of the country of birth and/or of the parents and to acquire a new one may well be determined by both factors. It has been argued that an increasing number of people are choosing a "strategic citizenship" for instrumental reasons (Harpaz and Mateos 2018). The fact is that nation states today are much more interdependent, open to global influences and thus weakened in their sovereignty; their national identity will thus lose some of its former relevance for personal identity. The emergence of a global human rights regime has made citizenship less important for securing social rights (Soysal 1994). However, the central thesis of this chapter is that the ideas, values and emotions connected with national identity and citizenship will remain highly relevant, even in a globalised world. The model of the nation state cannot be considered as an outdated, conservative idea. However, we should not equate this concept with an ethnically homogeneous, closed community. Some of the oldest nation states (e.g. Switzerland, Belgium, Canada) have been multicultural political communities from the beginning. Thus, we should consider nation states as communities of people who do things together, decide commonly about their fate and cooperate in all important things (Miller 2000). Such a nation state is connected closely to a particular territory; it provides a frame of solidarity in a world society determined, to a large degree, by anonymous market forces. As a collective actor, too, the nation state still remains the most important political unit (Mitchell and Fazi 2017; Weiss 1998).

\subsection{Citizenship and equality}

A sociological discussion of the idea of citizenship must include a systematic reference to social equality and inequality, which has been considered by many to be the central sociological issue (e.g. Dahrendorf 1974). The long-term, historical increase in social inequality from simple, tribal societies to high cultures came to a halt at the beginning of 
the modern era, with the emergence of the first democratic states embracing the idea of equality between all people and basic human rights (Lenski 1966). The British sociologist T.H. Marshall (1950) introduced the well-known distinction between civil, political and social rights, a distinction which he connected with a historical sequence. Civil rights were established by and large in the revolutions of the eighteenth century; they refer to individual liberties - such as the freedom of thought and speech, the right to own private property, the freedom to choose one's place of residence and occupation and the freedom to marry. Political rights were attained mainly in the nineteenth and early-twentieth centuries; they include the possibility for political participation for all and particularly the universal franchise in political elections. Social rights were attained only during the twentieth century; they provide the right to secure one's basic socio-economic needs and to participate fully in the socio-cultural life of a society. They include the provision of education, health services, unemployment and pension insurances and welfare benefits which, in most European countries, are provided by the welfare state. Altogether, the implementation of these rights contributed significantly to a massive improvement in the conditions of life for the population at large, as shown in the increase in incomes, consumption and life expectancy.

It is usually argued that the enforcement of civil and political rights has - by and large - been accomplished in most Western democracies but that, as far as social rights are concerned, considerable gaps still exist. The latter fact is obvious if we compare the extended list of basic social rights enumerated in the UN Declaration of Human Rights of 1948 with the factual situation even in well-developed European welfare states - not to speak of the poorer countries of the global South. I would argue, however, and propose the following three hypotheses:

1. Even civil and political rights have not been fully attained today everywhere in the world; access to citizenship, in particular, remains a central issue.

2. In recent times, some rights come under threat again and new social groups emerge which are not fully covered by existing rights.

3. There is still a need for the extension of possibilities for political participation beyond those in a representative democracy and franchise. In the following section, let us now look at some empirical facts which show the relevance of national identity and citizenship for personal identity.

\section{Empirical facts about people's views of national identity and citizenship}

Empirical data on three topics are presented here: the relevance which people attach to citizenship as an aspect of national identity, the identification of migrants with their countries of origin and destination and the surprisingly high rates of non-citizens who do not apply for naturalisation. 


\subsection{Citizenship considered as highly important for national identity}

Here, I use data from the International Social Survey Program (ISSP), a world-wide regular annual survey which covers between 40 and 50 countries around the world and in which I have participated actively since its foundation in the mid-1980s (see Haller, Jowell and Smith 2009). In each participating country, a short survey on a particular topic is carried out among a representative sample of the population. The topics are replicated after some years (usually about 10 years), so that we can simultaneously look at international differences and at changes over time. ${ }^{1}$ Two relevant issues have been covered in ISSP: a survey on National Identity - carried out in 1995, 2003 and 2013 - and a survey on Citizenship, carried out in 2004 and 2014.

A short remark on the scientific relevance of opinion surveys may be in order here. The opinions which people express in such surveys should not be taken at face value, particularly in the case of issues towards which people are indifferent and about which they have little knowledge. Three other facts, however, make such results very important. First, because we can assume that people are well aware of the problems associated with specific issues relevant to their lives; second, because attitudes are often closely related to behaviour; and, third, because public opinion is a significant determinant of political processes (Burstein 1998). We see in what follows that public attitudes often correspond very well to the dominant problems and the institutional-political situation of a country.

One question in the ISSP survey on national identity dealt directly with the issue of citizenship. We asked a question relating to the different components of national identity, which included citizenship: "What is important for being a true [national]?" A list of eight items was presented to the interviewees, the questions and answers of which are shown in Table 2.1.

Five characteristics are considered as very important for the identification of a person with a certain nation state, of which citizenship is one. More than half of the respondents consider citizenship as "very important"; if we include the answers "fairly important"; the proportion is 85 per cent (see also Haller et al. 2009). The other characteristics considered as very important for national identity are mastery of the national language, the feeling of belonging and respect for the laws and institutions of the country. These attitudes do not appear to have changed over time; the percentages were quite similar in 1995 and 2003.

It is interesting and relevant that the two items which are usually the basis for the automatic acquisition of citizenship at birth - to have been born in the country and to have ancestors of this country - are less frequently mentioned as relevant. Only 29 per cent and 37 per cent considered the items "to have [national] ancestry" and "to have been born in [country]" as very important; if we sum up very important and fairly important responses, the percentages are 69 per cent and 74 per cent respectively (for a recent study in Germany confirming this, see Miller-Idriss 2009).

\footnotetext{
More information on ISSP can be found on the website www.issp.org.
} 
Table 2.1. The relevance of citizenship among eight characteristics of a person's national identity, as seen by the population in 20 countries in 2013 (\%)

\begin{tabular}{|c|c|c|c|c|c|}
\hline $\begin{array}{l}\text { What is important for being } \\
\text { a true [Austrian]? }\end{array}$ & $\begin{array}{c}\text { Very } \\
\text { important }\end{array}$ & $\begin{array}{c}\text { Fairly } \\
\text { important }\end{array}$ & $\begin{array}{l}\text { Not very } \\
\text { important }\end{array}$ & $\begin{array}{c}\text { Not at all } \\
\text { important }\end{array}$ & Total \\
\hline $\begin{array}{l}\text { To be able to speak [the national } \\
\text { language] }\end{array}$ & 59 & 28 & 9 & 4 & 100 \\
\hline To feel like a [national] & 55 & 34 & 8 & 3 & 100 \\
\hline $\begin{array}{l}\text { To respect [national] political } \\
\text { institutions and laws }\end{array}$ & 52 & 35 & 10 & 3 & 100 \\
\hline To have [national] citizenship & 51 & 34 & 12 & 3 & 100 \\
\hline $\begin{array}{l}\text { To have lived in [country] for } \\
\text { most of one's life }\end{array}$ & 37 & 37 & 21 & 5 & 100 \\
\hline To have been born in [country] & 37 & 32 & 22 & 9 & 100 \\
\hline To have [national] ancestry & 29 & 28 & 28 & 15 & 100 \\
\hline $\begin{array}{l}\text { To be a [member of dominant } \\
\text { religion] }\end{array}$ & 18 & 17 & 27 & 38 & 100 \\
\hline
\end{tabular}

Source: International Social Survey Program 2013 "National Identity III"; Number of interviewed persons: 25,318-25,343 (varies by row because of differing missing values). Countries include Austria, Croatia, the Czech Republic, Denmark, Estonia, Finland, France, Great Britain, Hungary, Iceland, Ireland, Israel, Japan, Latvia, Lithuania, Norway, the Philippines, Russia, Slovenia, Switzerland and Taiwan.

We can also ask how salient the belonging to a certain nation is compared to other aspects of identity. In the survey on National Identity, we asked this question about the relative importance of different aspects of identity: "We are all parts of different groups. Some are more important to us than others when we think of ourselves. In general, which, in the following list, is the most important to you in describing who you are? And the second most important? And the third most important?" Ten different groups were listed: family or marital status, occupational status, gender, nationality, age group, race/ethnic background, religion, region, social class and preferred political party (Haller and Müller 2009). The findings showed that nationality is not felt to be very important for personal identity. Family or marital status is considered as the most important identity by 33 per cent of the respondents, occupation by 19 per cent, gender by 11 per cent and nationality by 9 per cent. If we count how often an identity group is mentioned at all (as the first, second or third most important one), family is mentioned by 54 per cent of the respondents and nationality by 27 per cent. Thus, we must conclude that national identity is not a highly important facet of personal identity. The same is likely to be true for citizenship.

\subsection{Dual national identities of migrants}

A central question is with which country migrants identify more strongly - with their country of origin or with their country of destination? Many factors are relevant here 
- the characteristics and experiences of the individuals as well as of their countries of origin and destination. However, let us first have a quick look at some relevant empirical findings.

In a recent survey among 600 immigrants from the former Yugoslavia and Turkey to Austria, we asked directly about their identification with the countries of origin and destination. The issue was whether the respondent felt more Austrian, Croatian or Serbian etc., more Turkish or both at the same time (see also Müller-Kmet and Bodi-Fernandez 2019 on this survey). The findings are reported in Table 2.2.

\section{Table 2.2. The identification of immigrants from the former Yugoslavia and from} Turkey living in Austria with their countries of origin and destination (\%)

\begin{tabular}{lcc}
\hline & \multicolumn{2}{c}{ Country of origin } \\
\cline { 2 - 3 } I feel ... & $\begin{array}{l}\text { The former } \\
\text { Yugoslavia }\end{array}$ & Turkey \\
\hline ... more like an Austrian & 40 & 20 \\
$\quad$... like an Austrian as well as a [Serbian, Croatian, & & 40 \\
$\quad$ Bosnian.../Turk] & 43 & 41 \\
\hline ... more like a [Serbian, Croatian, Bosnian.../Turk] & 16 & 4 \\
\hline
\end{tabular}

Source: Social survey among immigrants in Austria, 2016, $n=600$ (Aschauer et al. 2019). Immigrants were defined by their immigration background - that is, persons or their parents born in the former Yugoslavia or Turkey.

Here we can see that identification with both countries is very frequent among the two groups of immigrants; they are distinguished from each other insofar as immigrants from the former Yugoslavia already feel that they are Austrians more frequently than those from Turkey. However, this finding indicates that, for every immigrant, a phase in life probably exists where he or she feels connected to both countries - that from which s/ he emigrated and that in which s/he is now settled. A similar finding has been reported for Australia by Mariah D. Evans (1988; see also Bauböck 1994, 114; Fleischmann and Verkuyten 2016). It was also found that strong dual identifiers among the immigrants showed better psychological adjustment compared to those with a single ethnic or national identity (Zhang, Verkuyten and Weesie 2018). For children, the chance to develop a dual identity depends to a considerable degree on their mother's ethnic and national identities (Spiegler, Thijs, Verkuyten and Leyendecker 2018).

\subsection{Surprisingly low rates of naturalisation}

A further important empirical fact concerns the rates of naturalisation in different European countries, which provide an additional insight into the expectations and fears concerning the acquisition of a new citizenship. What is the most relevant here is the 
naturalisation rate - i.e. the relation between the number of naturalisations per year and the number of foreigners living a country at the beginning of the year.

Here we can observe a surprising fact - throughout Europe, these figures are very low. In 2017, 22.3 million third-country nationals were residents in the EU of whom only 825,000 acquired citizenship in one of the member states in the same year. ${ }^{2}$ Thus, only 3.6 per cent of the foreigners applied for and attained citizenship. There were significant variations between countries. However, even in the country with the highest rate, Sweden, the naturalisation rate was only around 8 per cent. In six countries in Central East Europe (including Austria, the Czech Republic, Slovakia and Slovenia) it was even less than 1 person per 100; in 11 more countries (including the United Kingdom, Spain and Germany with millions of foreign residents), it was less than 2 per cent. In Germany, for instance, more than nine million foreigners (out of a total of 82 million inhabitants) were legal residents in 2016 although the number of naturalisations was only 110,383 in that year. It is highly probable that many of those foreigners, often resident in the host country for over ten years, may have fulfilled all the criteria for receiving citizenship but did not apply.

These statistical figures, which indicate a low propensity to apply for the citizenship of the host country, are supported by other data. Tomas Hammar (1990, 84ff) reports survey data for the late 1980s in Germany, Australia and the United States. In Germany, only between 10 and 20 per cent of the respondents had the intention of applying. For the United States it was estimated that, in 1980, about 3.5 million foreigners were eligible for naturalisation but did not apply; by 2010, the number was estimated at eight million (Sumption and Flamm 2012). Immigrants from Mexico in particular - the largest group had a very low rate of naturalisation; higher rates could be observed among immigrants from Hungary and from Asian countries. In Australia, the low rate of naturalisation became a political issue. Celebrating its bicentenary in 1988, the government found that about one million of its residents had not bothered to apply for citizenship (Hammar 1990, 89ff). Therefore, a public campaign was started, under the motto "The Year of Citizenship", to encourage immigrants who qualified to naturalise. A survey asked why non-citizens did not apply. The findings also correspond to surveys in Germany, Sweden and other countries which showed that three factors are the most relevant: sheer indifference (I did not bother), the wish to remain a member of the country of origin and the wish to return later to the country of origin. A particularly important case is Germany. In 2019, this country had 81.6 million inhabitants: among them, no fewer than 20.8 per cent had a migration background, defined as having been born without German citizenship or to at least one parent without German citizenship. Of these, 9.9 million were foreign citizens (12 per cent of total inhabitants) and 13.3 million German citizens (13 per cent

2 See https://ec.europa.eu/eurostat/statistics-explained/index.php?title=Migration_and_migrant_population_statistics/de (12.12.2019) 
of all inhabitants). ${ }^{3}$ In the comprehensive German panel survey SOEP, foreigners were asked about their intention to apply for German citizenship: 8.7 per cent said "I will for sure" and an additional 11 per cent "Probably"; that is, all together only about 20 per cent (Worbs 2008).

If we look at patterns of naturalisation by countries of origin and destination ${ }^{4}$ and the intentions and rates of naturalisation corresponding to the origin countries of the foreigners, two facts emerge (for the USA, see also Chiswick and Miller 2008):

- The rate of naturalisation is usually low for people immigrating from neighbouring countries with a comparable level of development and a similar cultural and political background (for instance, Norwegians and Finns in Sweden; Germans in Austria; Latin Americans in Portugal and Spain).

- The rate is higher for immigrants and refugees from countries with political oppression (such as in the former communist countries of the GDR, Czechoslovakia, Hungary and Poland) and, in recent times, by refugees from terrorism- and war-ridden countries in Africa and the Middle East.

In general, the main factors - legal-constitutional, social-structural and individual - for the low naturalisations rates may be summarised in three points: ${ }^{5}$

- In certain states it is difficult to attain citizenship (due to requirements concerning the length of stay, employment and income, living conditions and administrative costs). Countries quite hostile toward immigrants in their legal rules in the early 1990 s were Austria, the United Kingdom and Switzerland; the most friendly were Belgium, France, the Netherlands and Sweden (Çınar, Hofinger and Waldrauch 1995). Since the 2008/09 economic crisis, the situation of immigrants has worsened in several aspects and many governments have implemented legal reforms, usually making naturalisation more difficult. In 2015, the countries the most open to immigration and integration in legal terms were Anglo-American and Nordic countries and those on the Iberian peninsula, while those which were the most unfriendly were the post-communist Eastern European countries and Turkey (MIPEX 2015; see also Bauböck 2007; Howard 2009). The legal situation, however, should not be confused with factual socio-economic integration, which often does not correspond with legal integration (see below).

3 Bevölkerung mit Migrationshintergrund, Bundeszentrale für politische Bildung, 19.9.2019 (http://www.bpb.de/nachschlagen/zahlen-und-fakten/soziale-situation-in-deutschland/61646/ migrationshintergrund-i, 18,12.2019)

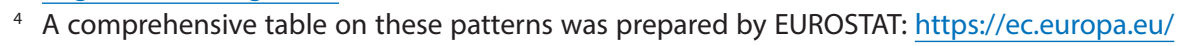
eurostat/documents/2995521/9641786/3-06032019-AP-DE.pdf/db95892f-11a3-4523-ba3b74db3799d874 (accessed 11 December 2020).

5 See also the systematic presentation of these factors in Hammar $(1990,98)$. 
- Migrants from liberal, developed democracies can obtain few additional advantages from acquiring the citizenship of the host country. Also the liberal nature of host-country laws can diminish such advantages if they reduce the rights between citizens and foreign residents so that denizens - foreigners who have permanent residence permits in a country - can freely choose their employment, bring in close family members and enjoy basic social rights concerning unemployment and oldage insurance and access to education and health care. This applies in particular to mobile EU citizens within the European Union; they can take up residence and employment in the EU wherever they wish. However, this also applies to long-term resident third-country nationals who enjoy robust rights as denizens (Council Directive 2003/109/EC). Nevertheless, the various levels of development between the sending and the host country help to explain the different naturalisation rates, especially where legal privileges are extensive and within a broad category of migrants. For these reasons, migrants from Bulgaria and Romania into Western EU member states apply more frequently for host-country citizenship than do migrants from wealthier EU countries.

- The continuing individual attachment to the nation state of origin is equally relevant. Studies have shown that immigrants are resistant to applying for naturalisation because they fear losing the contact, attachment and identity connected with their country of origin (for Austria, see Riegler 2000). If they have to renounce their previous citizenship, they will also lose their unconditional right to return to their country of origin.

\section{Citizenship and social integration}

Let us now discuss some additional aspects of citizenship as they appear from a sociological perspective. Two issues are dealt with here: the relationship between democratic citizenship and civic participation and obligations.

\subsection{Democratic citizenship requires participation}

Representative democracy can be seen as a formal arrangement responding to the fact that any political community is divided into elites and ordinary people and where only the former exercise power. Therefore, the use of power by persons in governmental positions must be restricted and controlled. This is Schumpeter's famous definition of democracy as a method in which people elect leaders, in competitive elections, who then have the right to govern for a limited period of time (Schumpeter 1942). From such a perspective, formal citizenship - which provides the right of suffrage (franchise) - is a central element of democracy. However, the Schumpeterian model, which sees an analogy between economic market and political processes, seems to be too restrictive from a sociological perspective. 
Alexis de Tocqueville (1805-1859), in his seminal book entitled Democracy in America (1969[1835]), saw a close connection between equality and democracy. He admired the vivid associational and political life in the United States but warned that an individualistic society would become atomised and uniform. He feared that, in Europe, where strong states had hindered the development of intermediate civic associations, a "tyranny of the minority" could emerge, leading to a new political centralisation and a "benign dictatorship". For Hannah Arendt (1972), citizenship is possible only in a truly public sphere which, in her view, includes two important elements:

- A spatial quality: citizens must meet in concrete public spaces where they can talk to each other, discuss and arrive at common solutions. This spatial quality - whether towns, provinces or nation states - also demarcates democratic polities from each other in territorial terms.

- A distinction between public and private interests: political activity is not (only) a means to an end but an end in itself; one engages in politics in order to also realise political ideals and principles like freedom, justice, equality and solidarity.

These ideas have direct implications for the concept of citizenship. A first is that collective identities are created through political discourse and action; this, however, is not achieved once and for all but only through constant renegotiation and struggle. The second is that citizenship is relevant not only at the state level but also in the political units below it - at the regional, urban and municipal levels. Third, citizenship is a participatory concept; the active engagement of citizens in the determination of the affairs of their community provides them with an experience of freedom and a sense of political efficacy (d'Entreves 2019); Benjamin Barber (1984) coined the concept of a "strong democracy" for such a polity. Thus, a federated system of councils through which citizens can effectively determine their own political affairs is an alternative to - or at least a substitute for, I would say - representative democracy based on bureaucratic political parties and anonymous institutions. The same is true for direct democracy as an important supplement of representative democracy, which is strongly endorsed by the general population. The ISSP Survey on Citizenship (2015) showed that 69 per cent of the 48,000 respondents in 38 countries around the world support the idea that "referenda are a good way to decide important political questions". The implication of such a view for the topic of this discussion is clear: naturalisation as such will not always change the social and political position of individuals fundamentally. It will do so only if citizenship is realised in an active endorsement of and participation in democratic life by all the people living on the territory of a political community.

\subsection{Citizenship as a set of obligations}

A corollary of the view of politics as a process of active discussion and engagement is that citizenship also implies obligations (Janowitz 1980; Turner 1990). The view of citi- 
zenship as a concept with ethical-moral implications finds expression when we speak about a "good citizen" - meaning a citizen who is actively engaged in civic associations and political offices. Three kinds of obligation are particularly relevant: to participate in elections, to pay taxes and to undertake military service. Let us begin with a look at the first of these three obligations because it is directly connected with citizenship and the franchise.

To take part in elections is an important civic duty, even if we adhere only to the minimalist Schumpeterian definition of democracy. A contentious issue is whether this obligation could or should be cast in legal terms. In order to see what the public thinks about this issue, we can again look at findings from the ISSP Survey on Citizenship of 2014 in which a question was asked about the different characteristics of a "good citizen"; among them, two related to voting in elections. Table 2.3 reports the findings.

\section{Table 2.3. Characteristics and virtues of a "good citizen": popular opinions in 38 countries around the world in 2013-2014 (\%)}

\begin{tabular}{lcccccc}
\hline & $\begin{array}{c}\text { Not at all } \\
\text { important } \\
\left(\mathbf{1 *}^{*}\right)\end{array}$ & $\begin{array}{c}\text { Important } \\
\mathbf{( 2 , 3 )}\end{array}$ & $\begin{array}{c}\text { Indiffer- } \\
\text { ent } \mathbf{( 4 )}\end{array}$ & $\begin{array}{c}\text { Important } \\
\mathbf{( 5 , 6 )}\end{array}$ & $\begin{array}{c}\text { Very } \\
\text { important } \\
\mathbf{( 7 )}\end{array}$ & Total \\
\hline $\begin{array}{l}\text { Good citizen: always } \\
\text { votes in elections }\end{array}$ & 5 & 6 & 2 & 28 & 53 & 100 \\
$\begin{array}{l}\text { Democracy: right for } \\
\text { citizens not to vote }\end{array}$ & 13 & 12 & 13 & 28 & 33 & 100 \\
$\begin{array}{l}\text { Good citizen: active } \\
\text { in social or political }\end{array}$ & 12 & 23 & 21 & 30 & 14 & 100 \\
$\begin{array}{l}\text { associations } \\
\begin{array}{l}\text { Never tries to evade } \\
\text { taxes }\end{array}\end{array}$ & 2 & 5 & 6 & 29 & 58 & 100 \\
$\begin{array}{l}\text { Serves in the } \\
\text { military (2004) }\end{array}$ & 16 & 14 & 12 & 29 & 29 & 100 \\
\hline
\end{tabular}

Source: International Social Survey Programme "Citizenship II", 2014; N=52.550; Item "Serve in the military": ISSP 2004; 38 countries, $\mathrm{N}=45,498$.

Note: ${ }^{*}$ The numbers in parentheses refer to the values given on a seven-point scale.

We can see, first, that large majorities of people around the world (81 per cent) support the idea that voting is a basic duty of a good citizen. However, there exist huge differences between countries. In the Philippines, Venezuela, Spain and Georgia, more than 70 per cent say it is "very important"; in Australia, the USA, Sweden and Norway between 60 and 70 per cent; in most post-communist Eastern European countries, including Russia, as well as in India, these are less than 54 per cent; the lowest proportion ( 23 per cent) can be found in Slovakia. The explanation for these huge differences seems straightforward. It is mainly a long history of democracy and the experience that democracy is working 
well (with low levels of corruption), which leads the respondents to attribute more duties to a citizen. All countries with little support for voting as a citizen's duty have had only a relatively short history of democracy and some of them are still only "semi-democracies", often ridden by high levels of corruption (Howard 2003).

Public support is much lower when it comes to a legal norm to vote. A majority (61 per cent) of the respondents think that citizens should also have the right not to vote. However, an obligation to vote has been considered by several scholars (Lijphart 1997; see also Spiro 2017). Two reasons can be given for this. First, turnout was and still is significantly higher when voting is obligatory; this can clearly be seen in a comparison of countries in Europe. In the European Parliament elections in 2019, turnout was 89 per cent in Belgium and nearly 60 per cent in Greece and Italy - all countries with obligatory voting; it was lowest (only between a quarter and a third of the electorate) in most post-communist EU member countries. High turnout can be regarded as strengthening the general legitimacy of representative democracy, since citizens who vote are more likely to accept decisions taken by the authorities or assemblies which they have elected.

Second, we know that turnout - and political participation in general - is lower among the less-privileged social classes and groups (Beeghley 1986; Lahtinen, Mattila, Wass and Martikainen 2017; Lijphart 1997). This means that the issues and problems which are the most relevant for them will get less attention in politics if turnout is low. Mandatory voting increases the participation rates and thus also the representation of socially marginalised groups more than those of other voters.

Let us also have a quick look at the two other duties of a citizen - to pay taxes and to serve in the military (in some countries, a fourth obligation exists, namely the duty to serve on juries). The obligation to pay taxes (which certainly also applies to denizens) seems particularly relevant in these times in which there is a significant increase of income inequality in many countries, an increase which particularly improves the situation of the highest income groups while disadvantaging the lower social classes (König 1999; Milanović 2005; Piketty 2014; Stiglitz 2013). We can mention three relevant issues in this regard.

First, the obligation to report income truthfully to the fiscal authorities is a problem mainly for self-employed people and entrepreneurs because they have to declare their income themselves. Those with very high incomes - and wealthy people in particular - have many possibilities of evading taxes by using legal strategies (Alstadsæter, Johannesen and Zucman 2018; Ötsch 2018; Piketty 2014; Ronen, Murphy and Chavagneux 2010; Scheve and Stasavage 2018). Tax-dodging efforts can be supported by corrupt tax officials and by an industry that sells wealth-concealment services. For the USA it is estimated that 30-40 per cent cheat on their returns for two reasons: because it is easy and because the risks and penalties are low. ${ }^{6}$ Even for Sweden, Norway and Denmark, it

6 See https://www.thefiscaltimes.com/2019/09/27/What-Tax-Cheats-and-Mistakes-Cost-IRS (26.2.2020), 
was estimated that the 0.01 per cent richest households evade about 25 per cent of their taxes by transferring parts of their wealth to offshore banks and territories (Alstadsæter et al. 2018). At the other end of the spectrum are many states in the global South where rich and influential people can more-or-less completely avoid being assessed for taxation. However, in some southern European countries, tax evasion is also a massive problem. The extremely high public debt of Italy, for instance, is also a consequence of the massive flight of money and capital towards Switzerland and other North-Western European countries (see Brooke 2016; Ronen et al. 2010).

If we look at public opinion on tax evasion, the findings are unequivocal: a large majority -87 per cent - of the respondents consider it as an important duty of a citizen "never to try to evade taxes"! " This attitude also varies significantly between countries: the consent is highest in the UK and the USA, Spain, Turkey and Japan and lowest again in the post-communist countries and India. Maybe citizens in these countries lack trust in their fiscal administrations; maybe many themselves participate in different forms of petty corruption.

In this regard, the United States' system of taxation could be a model for other countries. In most countries, a territorial-based taxation (taxing only incomes earned within the country) or a residence-based taxation is in force (taxing all income of people resident in the country). The United States is unique because it has a citizenship-based taxation system: Americans living abroad have to file a US federal tax return and pay US income tax no matter where they live. If the US has a bilateral tax treaty with their host country, income tax paid there will be deducted from their US tax debt. ${ }^{8}$ Such a system would discourage prominent rich people in Europe (such as football stars, artists or managers) from taking up residence abroad (typically in low-tax countries like Monaco) in order to avoid being taxed by their own governments.

A further problem concerns the population's inadequate knowledge and understanding of tax regulations and duties. Here, the government is called upon to make these procedures easier and to include them in school curricula. Citizens, as voters, should be encouraged to take a more active interest in tax affairs. Increasing proportions of the population resort to professional assistance, even for the most simplified of tax return forms (Janowitz 1980, 9; Kalleitner and Kittel 2018).

The third basic duty of citizens has historically been conscription - the obligation of young men to perform military service. This obligation has already had a very close relationship with citizenship in ancient Greece. The modern citizen mass army was introduced after the French Revolution. It not only turned out to be superior in terms of military power but it also created a state interest in turning all (male) persons living

7 Findings from the International Social Survey "Citizenship II", 2014.

8 See https://www.greenbacktaxservices.com/blog/paying-taxes-american-living-abroad/ (accessed 11 December 2020). 
on the state territory into full citizens while preventing the use of mercenary forces to conduct wars and to suppress citizen rebellions. The French innovation led to a demand for increasing numbers of soldiers in most other states. The bureaucratic obligation for each person on the territory of a state to continually carry a personal document proving his identity was a direct consequence of military-service obligations (Noiriel 1994). In most Western countries, however, conscription has been abandoned in recent years. ${ }^{9}$ This has removed one obstacle to the granting of dual citizenship to men although, already, in the past, most states exempted from military service their citizens who were living permanently abroad.

General conscription in modern times was progress compared to former systems, when soldiers were recruited by force. This was particularly the case in countries in which young men could choose between military service and an alternative community service. Some present-day authoritarian and conflict-ridden countries (e.g. Somalia, Afghanistan), however, combine general conscription with the use of force. Therefore, many young men flee in order to avoid a very long and life-threatening military service. With regards to conscription and military service, the problem of social inequality is also relevant. Rich and influential people can evade military service. Today, after the abolishment of obligatory military service, the American armed forces are somewhat disproportionately drawn from the lowest and highest parental-income classes; even immigrants are recruited with the promise that it will make obtaining citizenship easier (Asoni and Sanandaji 2013).

However, in a few countries, conscription is still in force and endorsed by the population. In January 2013, a referendum took place in Austria about the abolition of conscription but 52.4 per cent of the participants voted for its maintenance. Among the reasons for this result were the services of drafted soldiers in cases of natural disaster and the feeling of security which the army provided to people in the regions near the Iron Curtain when Soviet troops invaded Hungary in 1956 and Czechoslovakia in 1968; recently, the army was also used to assist border police in detecting irregular migrants.

So what about global public opinion in this regard? Table 2.3 shows that, in 2004, about a third of the respondents in 38 countries were strongly in favour of military service as the duty of a good citizen; summing up the positive answers, 58 per cent endorsed it. ${ }^{10}$ There exist significant differences between countries: military service is the most frequently considered as a citizen's duty in Israel, the United States, Brazil and some other Latin American states, as well as in Russia and several post-communist Eastern European countries; it is considered to be the least important in Germany, the Netherlands, Switzerland, the Czech Republic, Slovakia and Japan. A close connection seems to exist here

9 In 2013, only five of the 28 members of NATO still had obligatory military service (Denmark, Estonia, Norway, Turkey and Cyprus). See https://www.sn.at/politik/weltpolitik/wie-anderelaender-die-wehrpflicht-regeln-5357479.

10 In ISSP 2014, this item was unfortunately excluded. 
between the bellicose or peaceful orientation of a nation state (which is also related to its size) and the attitudes of its population.

There are several arguments in favour of conscription - it is said to instill maturity in and patriotic feelings among young men and to provide vocational training and thus open up opportunities for social ascent for men from the lower classes. Some have also proposed to replace male conscription by a general mandatory civil or national service for both young men and young women. While such an institution would remove gender inequality, it would also encounter serious obstacles. The whole volunteer system would be challenged, it would be difficult to provide enough jobs, the administration would be difficult and considerable sections of the population would oppose it strongly. It would also break Art. 4 of the European Convention on Human Rights, which forbids states to oblige their citizens to perform compulsory labour - thus, it is not a realistic option. ${ }^{11}$ Libertarians argue against conscription because they see it as a kind of "involuntary servitude", ${ }^{12}$ feminists consider it as sexist, serving the interests of patriarchy and an aggressive view of males (although recently some feminists have also advocated the drafting of women); from an economic perspective, it is a waste of time and manpower. Personally, I think that the abolition of conscription is a sign of human progress simply because it reduces the number of people who serve in the military; as a consequence, it may also increase the general rejection of war.

\section{Concluding remarks}

Citizenship is a central component of the national identity of people in modern societies. The two main propositions in this chapter were that citizenship involves a symbolic-identitarian and an instrumental-utilitarian meaning. Migrants, particularly those of the first generation, will typically have dual national identities in the sense of an attachment to both their country of origin and that of arrival. However, the individual relevance of citizenship varies significantly between the different nation states, depending on their socio-economic and political situation. Empirical data from the International Social Survey Program (ISSP) have been presented which reveal the attitudes of the general public around the world concerning the relevance of citizenship for personal and national identity. The proposition that citizenship has symbolic meaning was clearly supported. Data showing surprisingly low naturalisation rates in countries of immigration confirm that first-generation migrants have a dual bond - to their countries of both origin and destination. The propensity to apply for naturalisation, however, also depends on strate-

11 For summaries of the problems, see https://www.nytimes.com/2019/06/21/magazine/mandatory-national-service.html and https://www.procon.org/headline.php?headlinelD=005433 (accessed 11 December 2020).

12 See https://en.wikipedia.org/wiki/Conscription (accessed 11 December 2020). 
gic-utilitarian considerations: persons from poor and conflict-ridden countries are more interested in attaining the citizenship of their country of residence, while "denizens", who already hold most social rights in their new countries (as is the case for migrants within the European Union), are less interested in attaining a new citizenship.

The final section argued, following Alexis de Tocqueville (1969[1835]) and Hannah Arendt (1972), that citizenship should include civic participation - i.e. an active involvement in social and political life, as well as obligations - such as that of paying taxes and completing their military service. While the latter obligation has been suspended in recent times in many countries, at a time of increasing opportunities for tax evasion by rich people, the former is more relevant than ever. In this regard, too, international survey data were presented showing strong agreement on the obligation to participate in elections and pay taxes.

In conclusion, three issues are addressed from a sociological perspective: the targeted facilitation of naturalisation, expansion of the toleration of dual citizenship and the improvement of the situation of denizens.

The general improvement in access to citizenship is an aim that is supported by most legal scholars and political scientists. It must also be approved from a sociological perspective. It is certainly an important aim in those countries which still impose very harsh conditions for naturalisation. However, citizenship can and should not be granted unconditionally. The personal, social and political significance of the nation state and - as a consequence - national citizenship will remain an important social fact for the coming decades. An indiscriminate conferral of citizenship would hardly be tolerated by the population at large. Yet, if concrete conditions are mentioned, general attitudes are not so negative. In the ISSP Program 2013 National Identity III, carried out in 20 countries, the item "Legal immigrants who are not citizens should have the same rights as [country] citizens" was presented to the respondents; 39 per cent agreed with it while 38 per cent did not. In the ISSP survey of 2014, Citizenship II, the item was formulated thus: "Longterm residents of a country, who are not citizens, (should) have the right to vote in that country's national elections" - a statement which was supported by 48 per cent of the respondents and rejected by 28 per cent.

Clear and, to some degree, even strict conditions for naturalisation also have a positive function. Research on the integration of immigrants in Europe has shown that they are better integrated in those countries where access to social-security benefits and citizenship is more difficult and dependent on specific requirements, such as language knowledge (Koopmans 2015). This is not only the result of a selection process; strong requirements may also induce immigrants to invest more efforts into their integration. Immigration is effectively controlled in Canada and Australia and they also have high naturalisation rates (Bloemraad 2006). However, a goal conflict might exist here, particularly concerning refugees. Naturalisation would be particularly helpful for those persons (probably the less-well educated) who have difficulty obtaining any paid employment 
or any jobs at all (for Europe, see Koopmans, Statham, Giugni and Passy 2005; for the United States, Sumption and Flamm 2012). Thus, stronger restrictions on naturalisation can have a perverse effect, by excluding from naturalisation exactly those persons and groups who would need it the most (Vink 2015). Politics should, in particular, encourage those with less human and social capital to consider applying for citizenship. For highly qualified experts and the rich, it is much easier to gain citizenship. In many countries, a group of "moneyed immigrants" exists who buy houses, invest money and benefit from having a foot in the EU (in Cyprus and Malta, they can effectively buy European Union citizenship). Moreover, hidden racist attitudes, particularly against Muslim populations, might lurk behind strict requirements for naturalisation (Lewicki 2017). In this regard, governments should have the courage to act to some degree against public opinion, whereby a discrepancy exists in the attitudes toward dual citizenship for emigrants and immigrants; in regard to the former, they are much more positive than to the latter (Vink et al. 2019).

Another conclusion is to expand the tolerance for dual citizenship. This is proposed by most constitutional scholars and political scientists (Blatter, Sochin D'Elia and Buess 2018; Faist 2008; see also Harpaz and Mateos 2018; Spiro 2009; Vink, Schmeets and Mennes 2019). However, it should also be endorsed on the basis of sociological findings, which show that the attachment to and identification with the citizenship of the native country possesses high value for many emigrants. Dual social and national identities are a reality for many migrants, up to the second and often also the third generation. To assume that they will be characterised by a problematic "dual loyalty" is unfounded (Baron 2009). Surveys in 14 Western countries have shown that immigrants experience stronger attachment to the host nation if they have its citizenship, at least in those countries where the population attaches great importance to citizenship as a mark of national membership (Simonsen 2017). A Swiss study found that loyalty to the countries of descent and of residence is even positively related (Schlenker 2015). However, the granting of a second citizenship should be restricted to those persons who actually have a real interest in it and who, in some way, are ready to participate in the social, public and political life of a country. A well-ordered liberal democracy needs committed citizens (see also Bauböck 1994, 115). This principle would also preclude the collective conferral of citizenship to, for example, co-ethnic groups living outside a country (see Milano 2001; Pogonyi 2017).

For many migrants, especially internal ones within the European Union, the attainment of a new citizenship has no priority. They are already beneficiaries of comprehensive civil and social rights in their new country of residence, such as the right to settle there permanently and to freely choose their employment, as well as full access to the education and health systems and social security (the right to settle, however, is limited by the obligation to be able to provide for oneself in financial terms and to have health insurance). However, a situation where a large proportion of the residents are without 
full political rights is highly problematic. First, in some regards, these denizens are not really fully integrated in socio-economic terms, either because of specific access barriers or because they do not meet the necessary social preconditions (in terms of education, linguistic fluency or knowledge of unwritten social rules). Second, it is highly problematic for a democracy if significant fractions of the population do not have full rights to participate in politics. One could say that such a situation "educates" these people not to develop an interest in politics from the beginning (MIPEX 2015). The discrimination against long-term resident non-citizens applies not only to elections but also to civic and political associations of all kinds. A vivid democracy should encourage the active participation of all citizens in all their social and political affairs: in their children's schools, in local neighbourhoods, in town and municipal politics, in work organisations and unions and in voluntary civic and political associations. For citizens of EU member states, access to elections could also be granted at all levels after a certain period of settlement in another member country. European citizenship would have more real political meaning in this way, too. The idea of extending voting rights to immigrants is generally supported by the public in many countries, as shown earlier.

\section{Acknowledgement}

My thanks go to Rainer Bauböck and Christian Joppke for their detailed comments on a first version of this paper.

\section{References}

Abels, H. 2006. Identität. Wiesbaden: Verlag für Sozialwissenschaften.

Alstadsæter, A., Johannesen, N. and Zucman, G. 2018. Tax Evasion and Inequality. London: Centre for Economic Policy Research, Working Paper No. 1749. Available at: https:// gabriel-zucman.eu/files/AJZ2017.pdf.

Arendt, H. 1972. Crises of the Republic. New York: Harcourt, Brace and Jovanovich.

Asoni, A. and Sanandaji, T. 2013. Rich Man's War, Poor Man's Fight? Socioeconomic Representativeness in the Modern Military. Stockholm: Research Institute of Industrial Economics, IFN Working Paper No. 965.

Barber, B. 1984. Strong Democracy: Participatory Politics for a New Age. Berkeley, CA: University of California Press.

Baron, I.Z. 2009. The problem of dual loyalty, The Canadian Journal of Political Science, 42(4): 1025-1044.

Bauböck, R. 1994. Transnational Citizenship. Membership and Rights in International Migration. Cheltenham: Edward Elgar.

Bauböck, R. (ed.) 2007. Citizenship Policies in the New Europe. Amsterdam: Amsterdam University Press. 
Beeghley, L. 1986. Social class and political participation: a review and explanation, Sociological Forum, 1: 496-513.

Billig, M. 1995. Banal Nationalism. London: Sage.

Blatter, J., Sochin D'Elia, M. and Buess, M. 2018. Bürgerschaft und Demokratie. Bern-Wabern: Eidgenössische Migrationskommission EMK.

Bloemraad, I. 2006. Becoming a Citizen: Incorporating Immigrants and Refugees in the United States and Canada. Los Angeles: University of California Press.

Brooke, H. 2016. Capital without Borders. Cambridge, MA: Harvard University Press.

Brubaker, R. 1992. Citizenship and Nationhood in France and Germany. Cambridge, MA: Harvard University Press.

Brubaker, R. 2010. Migration, membership, and the modern nation-state: internal and external dimensions of the politics of belonging, Journal of Interdisciplinary History, 41(1): 61-78.

Burstein, P. 1998. Bringing the public back in. Should sociologists consider the impact of public opinion on public policy? Social Forces, 77(1): 27-62.

Çınar, D., Hofinger, C. and Waldrauch, H. 1995. Integrationsindex: Zur rechtlichen Integration von Ausländerlnnen in ausgewählten europäischen Ländern. Vienna: Institute for Advanced Studies, IHS Political Science Working Paper No. 25.

Chiswick, B.R. and Miller, P.W. 2008. Citizenship in the United States: the roles of immigrant characteristics and country of origin, Research in Labor Economics, 29: 91-130.

Cotterell, R. 1992. The Sociology of Law: An Introduction. Oxford: Oxford University Press.

Dahrendorf, R. 1974. Über den Ursprung der Ungleichheit unter den Menschen, in Pfade aus Utopia: Arbeiten zur Theorie und Methode der Soziologie. Munich: Piper, 352-379.

D'Entreves, M.P. 2019. Hannah Arendt, in Zalta, E.N. (ed.) Stanford Encyclopedia of Philosophy. Stanford, CA: Stanford University. Available at: https://plato.stanford.edu/ entries/arendt/ (accessed 10 December 2020).

De Tocqueville, A. 1969[1835]. Democracy in America. Garden City, NY: Doubleday.

Ehrlich, E. 1989[1913]. Grundlegung der Soziologie des Rechts. Berlin: Duncker \& Humblot.

Erikson, E. 1950. Childhood and Society. New York: W.W. Norton.

Esser, H. 2009. Pluralization or assimilation? Effects of multiple inclusion on the integration of immigrants, Zeitschrift für Soziologie, 38(5): 358-378.

Evans, M.D. 1988. Choosing to be a citizen: the time-path of citizenship in Australia, International Migration Review, 22(2): 243-264.

Faist, T. 2008. Dual Citizenship in an Age of Mobility. Transatlantic Council on Migration. Washington, DC: Migration Policy Institute.

Fleischmann, F. and Verkuyten, M. 2016. Dual identity among immigrants: comparing different conceptualizations, their measurements, and implications, Cultural Diversity and Ethnic Minority Psychology, 22(2): 151-165.

Fukuyama, F. 2018. Identity: The Demand for Dignity and the Politics of Resentment. New York: Farrar, Straus and Giroux. 
Haller, M. 2003. Soziologische Theorie im Systematisch-Kritischen Vergleich. Wiesbaden: VS Verlag.

Haller, M. and Müller, B. 2009. Social identities in comparative perspective, in Haller, M., Jowell, R. and Smith, T.W. (eds) The International Social Survey Programme 1984-2009: Charting the Globe. London and New York: Routledge, 175-196.

Haller, M., Jowell, R. and Smith, T.W. (eds) 2009. The International Social Survey Programme 1984-2009. Charting the Globe. London and New York: Routledge.

Haller M., Kaup, G. and Ressler, R. 2009. National identity in comparative perspective, in Haller, M., Jowell, R. and Smith, T.W. (eds) The International Social Survey Programme 1984-2009: Charting the Globe. London and New York: Routledge, 222-241.

Hammar, T. 1990. Democracy and the Nation State. Aliens, Denizens and Citizens in a World of International Migration. Aldershot: Avebury.

Harpaz, Y. and Mateos, P. 2018. Strategic citizenship: negotiating membership in the age of dual nationality, Journal of Ethnic and Migration Studies, 45(6): 843-857.

Heckmann, F. 2015. Integration von Migranten. Einwanderung und neue Nationenbildung. Wiesbaden: Springer VS.

Howard, M.M. 2003. The Weakness of Civil Society in Post-Communist Europe. Cambridge: Cambridge University Press.

Howard, M.M. 2009. The Politics of Citizenship in Europe. Cambridge: Cambridge University Press.

Janowitz, M. 1980. Observations on the sociology of citizenship: obligations and rights, Social Forces, 59(1): 1-24.

Joppke, C. 2010. Citizenship and Immigration. Cambridge: Polity Press.

Kalleitner, F. and Kittel, B. 2018. Das Einkommenssteuerverständnis in Österreich. Wissen und Zustimmung zur progressiven Besteuerung, in Haller, M. (ed.) Aktuelle Probleme der Finanzsoziologie. Die Fragestellungen von Rudolf Goldscheid Heute. Vienna: Lit Verlag, 173-191.

König, J.-G. 1999. Alle Macht den Konzernen. Das Neue Europa im Griff der Lobbyisten. Reinbek: Rowohlt Taschenbuch.

Koopmans, R. 2015. Social Cohesion and Immigration in Europe and North America: Mechanisms, Conditions, and Causality. London and New York: Routledge.

Koopmans R., Statham, P., Giugni, M. and Passy, F. (eds) 2005. Contested Citizenship. Immigration and Cultural Diversity in Europe. Minneapolis, MN: University of Minnesota Press.

Lahtinen, H., Mattila, M., Wass, H. and Martikainen, P. 2017. Explaining social class inequality in voter turnout: the contribution of income and health, Scandinavian Political Studies, 40(4): 388-410.

Lenski, E.G. 1966. Power and Privilege. A Theory of Social Stratification. Chapel Hill and London: The University of North Carolina Press. 
Lewicki, A. 2017. The blind spots of liberal citizenship and integration policy, Patterns of Prejudice, 51(5): 375-395.

Lijphart, A. 1997. Unequal participation: democracy's unresolved dilemma, American Political Science Review, 91(1): 1-14.

Marshall, T.H. 1950. Citizenship and Social Class and Other Essays. Cambridge: Cambridge University Press.

Mead, G.H. 1967[1934]. Mind, Self and Society. Chicago: University of Chicago Press.

Milano, E. 2001. The conferral of citizenship en masse by kin-states, in Palermo, F. and

Sabanadze, N. (eds) National Minorities in Inter-State Relationships. Leiden and Boston: Martinus Nijhoff, 145-166.

Milanović, B. 2005. Worlds Apart. Measuring International Global Inequality. Princeton, NJ: Princeton University Press.

Miller, D. 2000. Citizenship and National Identity. Cambridge: Polity Press.

Miller-Idriss, C. 2009. Blood and Culture. Youth, Right-Extremism, and National Belonging in Contemporary Germany. Durham and London: Duke University Press.

MIPEX 2015. Migration Policy Index. International Key Findings. Available at: http://www. mipex.eu/key-findings (accessed 10 December 2020).

Mitchell, W. and Fazi, T. 2017. Reclaiming the State. A Progressive View of Sovereignty for a Post-Neoliberal World. London: Pluto Press.

Müller-Kmet, B. and Bodi-Fernandez, O. 2019. Emotionale Integration, nationale oder duale Identitäten? In Aschauer, W., Beham-Rabanser, M., Bodi-Fernandez, O., Haller, M. and Muckenhuber, J. (eds) Die Lebenssituation von Migrantinnen und Migranten in Österreich. Wiesbaden: Springer, 241-269.

Noiriel, G. 1994. La Tyrannie du National. Le Droit d'Asyle en Europe (1793-1993). Paris: Calmann-Lévy.

Ötsch, S. 2018. Steueroasen, Steuerflucht und Steuervermeidung. Fakten, Folgen und Maßnahmen, in Haller, M. (ed.) Aktuelle Probleme der Finanzsoziologie. Die Fragestellungen von Rudolf Goldscheid Heute. Vienna: Lit Verlag, 109-143.

Peabody, D. 1985. National Characteristics. Cambridge: Cambridge University Press.

Piketty, T. 2014. Capital in the Twenty-First Century. Cambridge, MA: Harvard University Press. Pogonyi, S. 2017. Extra-Territorial Ethnic Politics, Discourses and Identities in Hungary. London: Palgrave.

Rehbinder, M. 2014. Rechtssoziologie. Munich: C.H. Beck.

Riegler, H. 2000. Zwischen Rechtserwerb und Identitätsbedrohung - Einbürgerung aus der Sicht der Migranten, in Pilgram, A. and Steinert, H. (eds) Sozialer Ausschluss - Begriffe, Praktiken und Gegenwehr. Baden-Baden: Nomos, 183-201.

Ronen, P., Murphy, R. and Chavagneux, C. 2010. Tax Havens. How Globalization Really Works. Ithaca, NJ: Cornell University Press.

Scheve, K. and Stasavage, D. 2018. Taxing the Rich. A History of Fiscal Fairness in the United States and Europe. Princeton, NJ: Princeton University Press. 
Schlenker, A. 2015. Divided loyalty? Identification and political participation of dual citizens in Switzerland, European Political Science Review, 8(4): 517-546.

Schumpeter, J. 1942. Capitalism, Socialism and Democracy. New York: Harper \& Brothers. Simmel, G. 2013[1908]. Die Kreuzung sozialer Kreise, in Simmel, G. Soziologie. Untersuchungen über die Vergesellschaftung. Munich and Leipzig: Duncker \& Humblot, 305-344.

Simonsen, K.B. 2017. Does citizenship always further immigrants' feeling of belongingness to the host nation? A study of policies and public attitudes in 14 Western democracies, Comparative Migration Studies, 5(3): 1-17. Available at: https://comparativemigrationstudies.springeropen.com/articles/10.1186/s40878-017-0050-6.

Soysal, Y. 1994. Limits of Citizenship. Migrants and Postnational Membership in Europe. Chicago: University of Chicago Press.

Spiegler, O., Thijs, J., Verkuyten, M. and Leyendecker, B. 2018. Can children develop a dual identity when immigrant mothers feel homesick? A short-term longitudinal study among Turkish immigrants, European Journal of Developmental Psychology, 16(5): 581-594.

Spiro, P.J. 2009. Dual citizenship as a human right, International Journal of Constitutional Law, 8(1): 111-130.

Spiro, P.J. 2016. At Home in Two Countries. The Past and Future of Dual Citizenship. New York: New York University Press.

Spiro, P.J. 2017. Citizenship overreach, Michigan Journal of International Law, 38(2): 173191.

Stets, J.E. and Burke, B.J. 2000. Identity theory and social identity theory, Social Psychology Quarterly, 63(3): 224-237.

Stiglitz, J.E. 2013. The Price of Inequality. How Today's Divided Society Endangers our Future. New York: Norton.

Sumption M. and Flamm, S. 2012. The Economic Value of Citizenship for Immigrants in the United States. Washington, DC: Migration Policy Institute.

Tajfel, H. 1978. Differentiation Between Groups. Studies in the Social Psychology of Intergroup Relations. London: Academic Press.

Taylor, C. 1989. Sources of the Self. The Making of Modern Identity. Cambridge, MA: Harvard University Press.

Turner, B.S. 1990. Outline of a theory of citizenship, Sociology, 24(2): 189-217.

Vink, M. 2015. Elusive Citizenship. Maastricht: Maastricht University, Inaugural Lecture. Available at: https://doi.org/10.26481/spe.20150501 mv (accessed 09 December 2020).

Vink, M., Schmeets, H. and Mennes, H. 2019. Double standards? Attitudes towards immigrant and emigrant dual citizenship in the Netherlands, Ethnic and Racial Studies, 42(16): 83-101.

Vink, M., Schakel, A.H., Reichel, D., Luk, N.C. and de Groot, R.-G. 2019. The international diffusion of expatriate dual citizenship, Migration Studies, 7(3): 362-383. 
Vordermayer, V. 2012. Identitätsfalle oder Weltbürgertum? Zur praktischen Grundlegung der Migranten-Identität. Wiesbaden: VS Verlag.

Weigert, A.J., Teitge, J.S. and Teitge, D.W. 1986. Society and Identities. Toward a Sociological Psychology. Cambridge: Cambridge University Press.

Weiss, L. 1998. The Myth of the Powerless State. Governing the Economy in the Global Era. Cambridge: Polity Press.

Worbs, S. 2008. Die Einbürgerung von Ausländern in Deutschland. Die Einbürgerung von Ausländern in Deutschland. Nuremberg: Forschungsgruppe Bundesamt für Migration und Flüchtlinge, Working Paper No. 17.

Zhang, S., Verkuyten, M. and Weesie, J. 2018. Dual identity and psychological adjustment: a study among immigrant-origin members, Journal of Research in Personality, 74: 66-77. 


\title{
Chapter 3
}

\section{The Toleration of Dual Citizenship: A Global Trend and its Limits}

\author{
Rainer Bauböck, European University Institute, Florence/ \\ Austrian Academy of Sciences, Vienna
}

\begin{abstract}
This chapter summarises the causes of the strong global trend towards the toleration of dual citizenship but then focuses on its possible limits and reasons for resistance by some states. I consider specifically why the two largest states in terms of population China and India - adhere to a policy of strict non-toleration of multiple citizenship out of security concerns and adversarial ideologies of national sovereignty. I also examine the Eastern European context where policies of regional hegemony (by Russia) and the mobilisation of ethnic kin minorities in the near abroad for buttressing the domestic hegemony of political incumbents (by Hungary) have triggered counter-reactions against dual citizenship in neighbouring states. In so-called Western democracies, security concerns about terrorism have not led to a retreat from dual citizenship but have turned a second citizenship into a potential liability, as the possession of it allows states to denationalise citizens whom they consider to be a threat. Finally, the chapter considers whether demand and supply for dual citizenship might shrink if the hyperglobalisation since the 1990s were partly reversed in response to pandemics and the climate crisis.
\end{abstract}

\section{Introduction}

There is a global trend towards a growing toleration of dual citizenship. This is a well-established fact. The multiple causes for this trend are also well-known and acknowledged in the scholarly literature. Less attention has thus far been paid to the limitations of this trend. This chapter considers, first, the particular national and regional contexts that help to understand why some countries have resisted the trend. Second, a wave of recent anti-terrorism legislation permits states to revoke citizenship as long as they avoid rendering stateless those thus deprived, which raises new questions about the unequal treatment of mono- and multiple citizens and the potential risks of multiple citizenship for individuals. Finally, there is a question that has barely been discussed thus far. How will the increasing instrumental uses of citizenship by individuals as well as states affect the future of citizenship as a bond between individuals and states and as membership in a self-governing political community?

Before examining these limits, this chapter first discusses how dual citizenship is generated and how its occurrence may be constrained by nationality laws (Section 2). It 
then provides a survey of global patterns and trends and summarises current knowledge about their drivers (Section 3). The rest of the chapter focuses on three types of limitation. The first of these concerns contextual deviation from the trend (Section 4) and the second, recent policies of citizenship revocation targeting multiple citizens (Section 5). In a more speculative vein, the final section considers whether a proliferation of multiple citizenships might undermine its value for individuals and states and whether a strong reduction of global mobility triggered by pandemics and the climate crisis might impact negatively on the demand for and supply of dual citizenship (Section 6).

As the argument in Sections 5 and 6 partly articulates a normative critique of citizenship policies, I need to clarify upfront the perspective from which this critique emerges. Most objections against dual citizenship in the past have been framed by a state-sovereignty perspective. The main concern was that states lose control over their citizens if these latter can be simultaneously nationals of another state, just as they would lose control over their territory if another state were to exercise coercive powers within their jurisdiction. As the analysis in Section 2 will show, this objection has not merely become anachronistic but is fraught by an inherent contradiction between a principle of national self-determination of citizenship by each state on the one hand and, on the other, international efforts to ensure that everybody has only one citizenship. A diametrically opposed critique has recently been proposed by cosmopolitan political theorists who are concerned that multiple citizenship contributes to global inequality by giving dual citizens more votes in national elections (Goodin and Tanasoca 2014) or by offering additional mobility rights to wealthy elites (Tanasoca 2018). ${ }^{1}$ By contrast, my normative perspective starts from the internal value of citizenship as a status of equal membership in a bounded political community and its external value for assigning special responsibilities for the protection of individual rights in the international order. ${ }^{2}$ This citizenship perspective supports a robust toleration of multiple citizenship for international migrants while, at the same time, revealing limits in terms both of who can claim access to several citizenships and of tipping points when proliferation undermines the value of citizenship itself.

\section{How to become a dual citizen}

An important fact that is often misunderstood is that dual citizenship is always the outcome of an interaction between national legal rules for the attribution of citizenship.

1 For a critical discussion see Bauböck et al. (2019).

2 Joachim Blatter has proposed an additional value of dual citizenship for democracy: it provides transnational input into domestic deliberations and often does so through politically empowering migrants whose countries of origin have been subjected to asymmetric power exercised by receiving states (Blatter 2011). 
Each of the states concerned awards its citizenship to the same person but they do so independently of each other, generally at different points in time ${ }^{3}$ and according to their own national laws. In this sense, no state can grant dual citizenship. Instead, there is a range of attitudes that "tolerant" states can take towards the other state(s) involved. At one end of the spectrum, the toleration of dual citizenship means that each state considers the person only as its own citizen and simply ignores that another state regards her or him in the same way. This attitude of turning a blind eye to second or third nationalities held by their citizens is typical for powerful and wealthy democracies, such as the US, Britain or France. At the other end, some countries recognise dual citizenship by explicitly permitting and/or regulating it through bilateral or multilateral treaties. A typical example are the treaties which Spain has concluded with most Latin American states that exempt these countries' nationals from the general rejection of multiple nationality in Spanish law while, at the same time, stipulating that the external second citizenship will be regarded as inactive ("dormant") when citizens reside in one of the two states concerned (Marín et al. 2015; Vonk 2012). In between these two poles, states can adopt various degrees of toleration or recognition of dual citizenship.

Similarly, negative attitudes of states towards dual citizenship can be articulated across a spectrum of different responses. Because dual citizenship is always co-produced by two independent states, it is generally not within the power of any single state to effectively prohibit all forms of dual citizenship, since it cannot force other states to adopt those rules that would guarantee a singular citizenship outcome in all cases. In many instances, states cannot even rely on all other states to provide information about whether their citizens also carry other passports. As we will see, major constraints on fighting dual citizenship are also created by international legal norms that states have subscribed to by ratifying international human-rights conventions.

Because each state controls only its own side of the dual citizenship equation, all it can do is threaten to withhold the granting of its citizenship or to revoke an existing citizenship in cases where it knows that the person also holds - or is about to acquire another nationality and is not willing or able to give it up. Most states find such blanket prohibition difficult to enforce across the many different ways in which they attribute their citizenship. We therefore need to distinguish between the different modes of citizenship acquisition - both at and after birth - in order to capture the variations in (non-) toleration across states.

Finally, hostile attitudes to dual citizenship are articulated not only through regulating access to the status but also through restrictions on the exercise of citizenship rights. Traditionally, international lawyers have assumed that there is one specific right that mono-citizens enjoy but dual citizens lose: states cannot offer diplomatic protection to their citizens against violations of their rights by another state if these persons are also

3 The exception is when dual citizenship results from states' rules on acquisition at birth. 
citizens of that state. ${ }^{4}$ Yet state practice has not always followed this rule, grounded in the doctrine of non-interference in the internal affairs of other countries. Countries like the US, France and Britain, in particular, which tend to tolerate dual citizenship through ignoring second citizenships, have extended their protection to dual citizens when these run into trouble in their second countries. It has become questionable whether state practice still backs an international legal norm against diplomatic protection in such cases. Moreover, international courts have started to recognise exceptions in cases of human-rights violations or when the citizenship of the state exercising diplomatic protection is considered the person's effective nationality (e.g. because it matches the person's habitual residence (Hailbronner 2003, 22-25). ${ }^{5}$

Other restrictions targeting multiple citizens concern their domestic rights and express reservations about their loyalty. The most common one is exclusion from high public office, such as that of a Member of Parliament. Australia has been fully tolerant of dual citizenship status for some time but its constitution prohibits "subjects or citizens of a foreign power" to sit in the federal parliament. As a result, five MPs, some of whom had not even been aware that they held a second citizenship, attributed to them at birth, lost their seats in 2017. ${ }^{6}$ In 2010 the European Court of Human Rights rejected a similar prohibition in Moldova but clarified that it was permissible to have such restrictions for dual citizens as long as these are not introduced by partisan legislation aimed at excluding political opponents - which had been the case in Moldova. ${ }^{7}$ Even more comprehensive restrictions of access to public office are common for naturalised citizens in Latin American states. Since most of these countries tolerate dual citizenship, these curtailments of political rights mostly affect dual citizens by naturalisation, turning them into second-class citizens. Many countries have, however, adopted a rather more relaxed attitude. For example, in Switzerland, jobs in the secret service or law enforcement are still reserved for mono-citizens; otherwise, there is a clear trend towards the toleration of dual citizenship - also in sensitive security-related positions such as border guards (Blatter, Sochin D'Elia and Buess 2018).

Dual citizenship emerges through the interaction of state rules for the automatic attribution of citizenship by birth and those for an individual change of citizenship after birth. For birthright citizenship, there are two combinations of rules that will result in dual citizenship while, for naturalisation, there is only one (Sejersen 2008).

4 See the Convention on Certain Questions Relating to the Conflict of Nationality Laws (The Hague 1930), Art. 4: "A State may not afford diplomatic protection to one of its nationals against a State whose nationality such person also possesses".

5 Note that this norm does not prevent states from offering consular protection and services to their dual citizens since these do not involve taking action against the host state.

6 See http://globalcit.eu/australian-high-court-rules-that-dual-citizens-are-ineligible-to-sit-inparliament/ (accessed 08 December 2020).

7 Tanase v. Moldova, Application No. 7/08, European Court of Human Rights, 27 April 2010. 


\subsection{Dual citizenship by descent}

If a child is born to a mother with citizenship of state $A$ and a father who is a citizen of state $B$, the child will be born as a dual citizen of $A$ and $B$ if both countries attribute citizenship by descent (ius sanguinis). Dual citizenship can be avoided only if states discriminate on grounds of gender. Until the 1970s, even Western democracies (including Austria) did so by passing their citizenship on to the next generation only from the father's side. A second common rule was that, upon marriage, a female spouse automatically acquired her husband's citizenship and lost her original one, in which case children born to a married couple with different national origins again only acquired the father's original citizenship. A third rule that reduced cases of dual citizenship by descent, which was present in Austria until 2013, is that children born out of wedlock acquire only their mother's but not their father's citizenship. International conventions and international as well as domestic courts have struck down all three rules on grounds of gender discrimination. They have thus been phased out in most liberal democracies but can still be found in a significant number of states in Africa, the Middle East and Asia.

\subsection{Dual citizenship by territorial birth of immigrant origin}

If state $A$ attributes citizenship to children born on its territory (ius soli) and state B attributes citizenship to children born to citizen parent(s) outside its territory (extraterritorial ius sanguinis), then the second generation of emigrant origin from country B born in country A will be dual citizens by birth. The numbers of dual citizens through ius soli in immigration countries can be reduced by the country of birth if ius soli is made conditional - e.g. by requiring that a parent have a certain residence permit or length of residence in the country or that the child will acquire citizenship only after having lived in the country for several years. A few countries, among them Germany, have also made ius soli provisional by requiring that the child choose one of the two citizenships when he or she reaches the age of majority. In 2014, Germany relaxed this "option duty" considerably by exempting children who have lived in Germany for eight years, have attended school there for six years or have completed their school education or vocational training there (Faharat and Hailbronner 2020; Spiro 2016).

The acquisition of dual citizenship by territorial birth can also be prevented or constrained through certain provisions in the laws of countries of origin. State B can fully prevent dual citizenship if it applies extraterritorial ius sanguinis only to those children who do not acquire another citizenship at birth. This rule has been adopted by the two largest states in terms of population - China and India - whose policies are further discussed in Section 3. Alternatively, state B can accept dual citizenship at birth but apply an expiry date on it by requiring that children born abroad to citizen parents must return before a certain age (usually between 18 and 23) or otherwise establish a close connection to their parents' country of origin in order to retain the citizenship of state 
B. This rule is applied in European Nordic states. A third possibility is that state B can let the first generation born abroad retain citizenship for life but suspend extraterritorial ius sanguinis for the subsequent generation - i.e. those whose parent(s) had already been born abroad - a rule adopted, for example, by Canada. Finally, state B can (as Austria does) withdraw its citizenship if a person voluntarily acquires another citizenship after birth. Emigrants from state $B$ who become citizens of state $A$ by naturalisation will then lose their citizenship of origin and can no longer pass it on to their children born in state $A$.

\subsection{Dual citizenship by naturalisation}

Dual citizenship emerges from naturalisation only if state $B$ does not withdraw its citizenship if its citizen acquires the nationality of state $A$ through naturalisation and if state A does not require renunciation of or release from citizenship of state $B$ as a condition for naturalisation. We can call the first part of this combination the toleration of dual citizenship in outgoing naturalisation (by state $B$ ) and the second part toleration in incoming naturalisation (by state A). Dual citizenship is the outcome only if both states play their respective parts in this game of toleration. This does not mean, however, that dual citizenship will emerge only if both states tolerate dual citizenship in incoming as well as outgoing naturalisations. As we will see in Section 3, a significant number of states engage in asymmetric toleration. If there is one-way migration from state $B$ to state $A$ and state $B$ tolerates dual citizenship only in outgoing naturalisations while state $A$ tolerates it only in incoming ones, then these migrants still have the opportunity to become dual citizens, although those migrating in the opposite direction - from A to B - can only change their citizenship if they are willing to give up their previous one.

Past efforts by international lawyers to curb dual citizenship have focused on asking states to withdraw their citizenship in outgoing naturalisations. This principle was enshrined in Chapter 1 of the 1963 Strasbourg Convention on the Reduction of Cases of Multiple Nationality and on Military Obligations in Cases of Multiple Nationality. This convention does not ask states to introduce the renunciation of a previous citizenship as a condition for naturalisation but expects states adhering to the convention to withdraw their citizenship if a person voluntarily acquires the citizenship of another contracting state - an effort which has been spectacularly unsuccessful. As of 2020, all member states of the convention, apart from Austria and the Netherlands, have either left the convention altogether or have denounced their obligations under Chapter 1.

Loopholes for the exceptional toleration of dual citizenship exist in both incoming and outgoing naturalisations. Many states that generally require the renunciation of a previous citizenship drop this request where it is impossible to fulfill because the country of origin adheres to a doctrine of perpetual allegiance and refuses to release its citizens. Austria, Germany and the Netherlands all accept dual citizenship in this case, which creates a strange inequality of treatment between applicants for naturalisation from, for example, the Arab states or Iran - where renunciation is impossible - and those from 
most other states of origin that do allow it for their emigrants. A similar reason for special toleration applies also to refugees who cannot be expected to request and receive release from a state of origin that has persecuted them or denied them protection. A different and very common reason for exceptions is where incoming naturalisations are considered to be in the interest of the state. Many states (among them Austria) waive renunciation requirements for fast-track naturalisation on the grounds of special achievements in sports, culture or science, cultural affinity with the majority population and investment or the restitution of citizenship for the victims of non-democratic regimes in the country's history. Finally, some countries, such as the Netherlands, also exempt foreign spouses or partners of national citizens, who are generally a large group among naturalisation applicants.

Exceptions are equally common in outgoing naturalisations. Austria and many other countries allow expatriates (on the basis of a highly discretionary decision in the Austrian case) to retain their citizenship of origin if they can demonstrate that they are going to maintain close ties to the country or that they would suffer serious disadvantages unless they acquire the citizenship of their host country. Secondly, the now-obsolete norm that countries should denationalise their expats if these acquire a foreign nationality applied only to voluntary acquisitions but not to automatic ones. Automatic naturalisations have become rare although they were quite common the past, especially in the case of marriage to a citizen. Until 2008, Austria had a peculiar rule that full university professors automatically acquired Austrian citizenship when taking up their chairs, without having to renounce their previous nationality.

\section{Global and regional trends and patterns}

Although GLOBALCIT provides a wealth of data on nationality laws, it is impossible to take into account all the degrees and nuances of dual-citizenship toleration explained in the previous section in a global comparison. Only the ground rules can be covered when classifying national laws as either tolerant or intolerant. However, it is crucial not to mix up the three different pathways in such a coding exercise, as is frequently done in comparative literature that considers only renunciation requirements in incoming naturalisations (Howard 2009; Janoski 2010; MIPEX 2015).

There has been, until now, no longitudinal global dataset on the toleration of dual citizenship acquired through the two birthright combinations or through incoming naturalisation. ${ }^{8}$ Maarten Vink and his colleagues have, however, compiled the MACIMIDE

8 Sejersen's (2008) pioneering effort was based on longitudinal data which also included the toleration of birthright dual citizenship and incoming naturalisations but the dataset has not been published and seems to contain some gaps, inaccuracies in the data and occasional misinterpretations of legal provisions. The GLOBALCIT dataset may still contain some errors 
Global Expatriate Dual Citizenship Dataset, which shows a strong and steady increase of toleration in outgoing naturalisations from a low point of 35 per cent of states existing in 1962 to 76 per cent of all states in 2020 (Vink, de Groot and Chun Luk 2020). The latter number is composed of states that tolerate dual citizenship while also allowing for voluntary renunciation and those whose acceptance of dual citizenship among expatriates results from a doctrine of perpetual allegiance. If we distinguish between these subcategories, we find that the share of states where citizenship is automatically lost through outgoing naturalisation has decreased sharply from 65 per cent in 1962 to 23 per cent in 2020. The percentage of countries where retaining a citizenship of origin is compulsory has increased only slightly from 7 to 10 per cent - in contrast to the numbers of states where retaining or renouncing a citizenship of origin is an individual choice, which has risen steeply from 28 to 67 per cent. ${ }^{9}$ The rise in dual citizenship toleration by countries of origin is thus not so much due to authoritarian policies of control over their diasporas as to a liberalisation of their citizenship policies.

Grouping countries by world regions shows that the general upward trend towards greater toleration is the same in all world regions whereas the speed of change is different: while Europe as a whole follows the global average, toleration in the Americas and Oceania has risen faster and lags somewhat behind in Africa and Asia. In 2019, 91 per cent of all states in North, Central and South America accepted dual citizenship for their expatriates, whereas only 65 per cent of Asian states did so (Vink et al. 2019). Reversals of liberalising reforms are very exceptional for both outgoing and incoming naturalisations. The Netherlands is a rare case where a renunciation requirement in naturalisations was suspended (in 1991) but reinstated in 1997 and tightened in 2010, as a result of the rejection of multicultural integration policies in favour of mandatory civic integration (Spiro 2016; van Oers, de Hart and Groenendijk 2013).

Vink and his collaborators tested several hypotheses about what made countries switch from the non-toleration to the toleration of dual citizenship in outgoing naturalisations (Vink et al. 2019). They found a regional diffusion effect - countries are more likely to adopt toleration if their neighbours have done so before. Secondly, they found a

of this kind but the involvement of country experts in collecting the data reduces these risks. Harpaz (2019) compiled a global dataset on dual citizenship toleration in incoming and outgoing naturalisations for two years (1990 and 2016) and a limited number of countries (76 and 88 respectively). See also Harpaz's Chapter 5 in this book.

9 Data for 2020, and our own calculation from the MACIMIDE Global Expatriate Dual Citizenship Dataset (Vink, de Groot and Chun Luk 2020). The dataset provides information on expat dual citizenship for 195 states in 2020. When interpreting these data, one needs to bear in mind that the number of independent states has greatly increased since the 1960s due to decolonisation and the break-up of socialist federations in Eastern Europe after 1989. The increase is thus due not only to policy changes but also to new states adopting a policy of dual citizenship toleration from the start. 
positive correlation with migrant remittances, which is in line with a common hypothesis that migrant sending countries have changed attitudes - from considering their emigrants as traitors or lost populations to regarding them as an asset (Bauböck 2003). The third significant correlation is with the granting of voting rights to non-resident citizens. This suggests that the change of attitudes towards diasporas may not only be brought about by governments trying to use them as an economic and political resource (Gamlen 2019) but also by diaspora organisations campaigning for dual-citizenship toleration and using their electoral power for this goal. No significant differences with regards to the policy change emerge, however, between democratic and non-democratic regimes.

Although we do not yet have time-series data for the other pathways to dual citizenship covering longer periods, their distribution across countries in the present is known. Table 3.1 shows the combination of toleration in incoming and outgoing naturalisations for a global set of 175 states in 2018. Countries have been coded cautiously in such a way that those which accept dual citizenship in many cases but not by default (as, for example, Germany and the Netherlands) are considered non-tolerant. Nearly half (47 per cent) of all countries fully tolerate dual citizenship by naturalisation, while only 18 per cent (among them Austria) remain in the group that rejects dual citizenship for both immigrants and emigrants. Table 3.1 also reveals that countries which accept dual citizenship asymmetrically are more often favourably biased towards their expatriates (19 per cent) than towards their immigrants (15 per cent).

Table 3.1. Dual citizenship in incoming and outgoing naturalisations in 2016

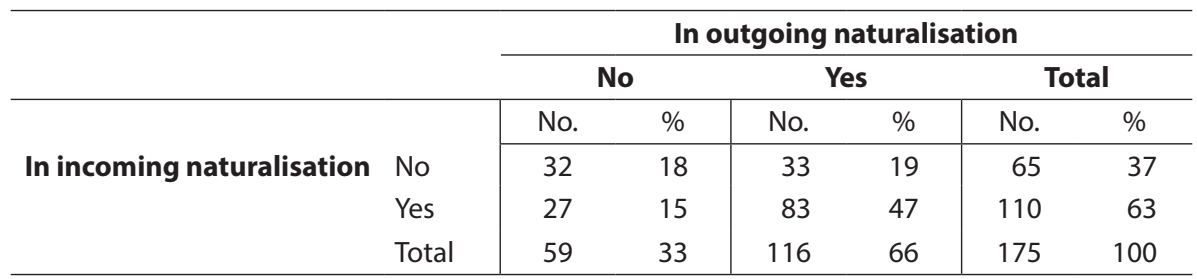

Source: GLOBALCIT, own calculations

Maps designed by the IOM's Global Migration Data Analysis Centre from the GLOBALCIT dataset show the regional distribution of these four types of (non-)toleration of dual citizenship through naturalisation (IOM 2019). In the Americas, Chile, Mexico and a majority of Central American states are the exceptions that tolerate dual citizenship for emigrants but not for immigrants, whereas all other states embrace symmetric toleration. South and East Asia (from Pakistan to Japan) provide the strongest contrast, with a clear prevalence of symmetric non-toleration of dual citizenship. Africa is predominantly tolerant in both ways but with significant exceptions. Europe is the continent that presents the most mixed picture. In Western Europe, only the Netherlands, Germany, Spain and 
Austria still cling to general non-toleration. However, in the former three countries, the renunciation requirement is waived in the majority of naturalisations, which is not the case in Austria. Among former socialist states, the Baltic countries and Ukraine also fall into this category, whereas the traditional emigration countries of the Balkans accept dual citizenship in outgoing but not in incoming naturalisation.

For the EU states we also have data on the restriction of dual citizenship acquired by birth. These are rare in Europe, mainly because international and European human-rights law has banned the gender discrimination which, in the past, had secured the attribution of only paternal citizenship at birth. We find only four EU member states where dual citizenship is constrained not only in incoming and outgoing naturalisations but also when acquired at birth (Honohan and Erdilmen 2020). Germany is the only case where dual citizenship acquired iure solis is provisional. As already explained above, children who have obtained German citizenship through territorial birth must choose between their German and an inherited foreign citizenship before the age of 23 but only if they have not spent much of their childhood in the country. However, Germany fully tolerates dual citizenship involving the nationality of another EU member state. Latvia applies an option duty to children who have acquired two citizenships iure sanguinis both for domestic and extraterritorial births but again exempts EU nationalities as well as EFTA and NATO member states, Australia, Brazil and New Zealand from this condition (for birthright and naturalisation). ${ }^{10}$ Slovenia and Croatia try to prevent dual citizenship acquisition only for extraterritorial births, requiring in this case that both parents be citizens, which still permits dual citizenship through a combination of extraterritorial ius sanguinis with ius soli.

The strength of the trend towards the toleration of dual citizenship is impressively demonstrated in a recent report by Luuk van der Baaren (2020) who finds that a majority of $16 \mathrm{EU}$ member states applied none of the possible restrictions on dual citizenship in 2018 that I have discussed in this section. Since holding dual citizenship is only possible if both of the countries involved tolerate it, we must consider dyadic combinations of EU member states to find out how often mobile EU citizens can actually become dual citizens. Van der Baaren has calculated that, out of 756 possible dyadic citizenship constellations between EU member states, 461 (61 per cent) involve the full toleration of

10 The principle of non-discrimination between citizens by birth and by naturalisation articulated in Article 5(2) of the European Convention on Nationality is more often violated by discriminating against naturalised (dual) citizens but the German and Latvian option duties show that restrictions can also target citizens by birth whose citizenship is conditional. It is true that the two countries do not generally tolerate dual citizenship in incoming naturalisations, so the option duty for birthright citizens may be argued to be in line with a general policy of preventing dual citizenship. However, as the German legislator realised in 2014, there is a major difference between conditions for the acquisition of citizenship and threatening those who have lived in the country for most of their lives with the revoking of their citizenship unless they renounce another one that they have inherited. 
dual citizenship by both countries. Factoring in the number of naturalisations in the same year, he concludes that 92 per cent of EU citizens acquiring the nationality of another EU member state in 2018 could legally retain their original citizenship because they were situated in a constellation where dual citizenship is fully tolerated. This very high number may be explained by the fact that EU citizens enjoy strong protection of their rights in other member states and are mostly unwilling to give up their citizenship of origin. As voting rights at the national level remain strongly tied to national citizenship, the non-toleration of dual citizenship creates a major obstacle to the full political integration of mobile EU citizens.

\section{Deviant patterns of dual-citizenship promotion and restriction}

Summarising findings in the literature (Hammar 1990; Sejersen 2008; Spiro 2016), we can identify the following main drivers of the global trend towards dual-citizenship toleration: (1) the declining number of international wars after World War II, which reduced fears about the disloyalty of dual citizens and conflicts over military conscription; (2) the prohibition of gender discrimination in nationality law that was pivoted by the 1979 Convention on the Elimination of all Forms of Discrimination Against Women (CEDAW); (3) the change in states' attitudes towards their expatriates and diasporas that has greatly strengthened the extraterritorial dimension of citizenship; and (4) the transformation, especially of European countries, through large-scale immigration. Immigration diminished the historic difference between European emigrant nations and American immigrant nations, making the former more open towards accepting dual citizenship for first-generation immigrants and second generations born on their territory.

Each of these causal mechanisms was reinforced through the - mostly regional - diffusion of legal standards and policies, with states imitating their neighbours and other member states in regional unions. However, even a global policy trend does not allow firm predictions about future developments. On the one hand, a slightly flattening curve of dual-citizenship toleration in outgoing naturalisations since 2005 (Vink et al. 2019) suggests the possibility that the trend may soon reach saturation point. This would mean that states that have thus far not changed their laws towards toleration may be resilient because of contextual reasons that are stronger than the causes underlying the global trend. A second possibility is a reversal of the trend itself in a scenario of deglobalisation, which I consider in Section 6. I now briefly present four cases illustrating the different contexts in which opposition to dual citizenship has hardened.

As mentioned in Section 2, China and India are among the most restrictive states since they attempt to fully prevent dual citizenship at birth as well as in naturalisations. They are also the largest countries on earth and their resistance blocks access to dual citizenship for more than one third of the world's population. It is thus is worth considering the reasons for their exceptionally tough stance. In the People's Republic of China 
(PRC) the policy can be traced back to the Cold War era, when the PRC abandoned the principle of perpetual allegiance by allowing for voluntary renunciation among Chinese emigrants and adopting a single nationality principle. Following the model set by socialist states in Europe, the main instrument with which to achieve this goal was a series of bilateral treaties with other states to prevent dual nationality. As this proved a largely unsuccessful approach, a new nationality act of 1980 stated the general principle that "[t]he People's Republic of China does not recognize dual nationality for any Chinese national" and introduced the automatic loss of Chinese citizenship in the case of the acquisition of a foreign nationality by naturalisation (Low 2016, 7). The rise of China's wealth and global power has created strong demands for dual citizenship among the Chinese diaspora and the PRC has become interested in the return migration of highly skilled and high-income people of Chinese origin. Choo Chin Low reports on attempts by Chinese expats to lobby the authorities in a bid to persuade them to change their policies or to introduce a Chinese Overseas Citizenship for former Chinese nationals that would resemble the Indian model discussed below (Low 2016, 28). As a weaker alternative, the Chinese government has introduced and recently facilitated access to a "green card" granting foreign nationals a relatively secure status and rights, which is meant to attract Chinese-origin returnees. The authorities have, however, firmly rejected softening their prohibition of dual citizenship. Since 2014, the government has even stepped up its attempts to close loopholes by withdrawing local household registration (hukou) from Chinese citizens who it suspects are concealing a second nationality. Low (2016) identifies security concerns and the fight against corruption as the main reasons for this attitude. According to Chinese media reports, 18,000 officials have escaped the country since the 1990s, depriving it of 800 billion yuan (ibid., 13). The global rise of the PRC has thus not led to a relaxing of attitudes towards dual citizenship, mainly because - in continuity with its communist past - the regime remains obsessed with domestic security and clings to a conception of sovereignty that excludes overlapping personal jurisdictions due to multiple nationalities. ${ }^{11}$

As in the case of China, security concerns have been a major obstacle to the relaxing of a policy of singular citizenship in India. The context and nature of these concerns are, however, very different. In India, dual citizenship has been blocked by conflicts over postcolonial borders and the composition of the population. The traumatic experience of the partition of the British colony between India and Pakistan in 1947 cast a long shadow over later attempts to provide a form of quasi-dual citizenship to "Persons of Indian Origin" (PIOs) since 2003 which, in 2011, was merged with an "Overseas Citizenship of India" (OCI) - first introduced in 2005 (Naujoks 2015). The Constitution of 1950 had

11 However, even in China, the legal prohibition of dual citizenship may still leave loopholes open for citizens who obtain a new nationality but conceal their new status in order to keep their Chinese hukou (personal communication by Choo Chin Low, 16 November 2020). 
deprived those who had moved to Pakistan of their Indian citizenship while including as citizens those who moved in the opposite direction. It also adopted the principle of automatic termination of Indian citizenship as a consequence of the voluntary acquisition of a foreign nationality before January 1950. The Citizenship Act of 1955 and later amendments and citizenship rules in effect lifted such temporary limitations and made the ban on dual citizenship a permanent feature. Ius soli, which had been a British colonial legacy, was phased out in 1986 by stipulating that those acquiring Indian citizenship by territorial birth must also have a parent with Indian citizenship, thereby closing off a major source of dual citizenship by birth (Ashesh and Thiruvengadam 2017). India has been plagued by terrorism since independence and heightened security concerns seem to have played a role in preventing the option of full dual citizenship for the 20-25 million-strong Indian diaspora. $\mathrm{OCl}$ is essentially an immigration status for foreign nationals of Indian origin - other than Pakistani and Bangladeshi nationals and those with Pakistani or Bangladeshi parents. It provides its holders with multiple entry and a life-long visa to visit India, residence and employment rights but excludes them from voting rights and access to public office or property on farmland. ${ }^{12}$

Another border-related security concern is about the irregular immigration of Muslims, especially from Bangladesh, into the Eastern state of Assam. The Assam Accord of 1985 required that residents who had fled from what was then still Pakistan to India between 1966 and 1971 had to register to obtain their Indian citizenship. This also de facto excluded later arrivals from access to regular status and citizenship (Ashesh and Thiruvengadam 2017). A recent campaign to register Indian citizens specifically targeted populations in Assam who lack documentation on their residence status, as many earlier arrivals still do. A new immigration law, proposed by the BJP (Bharatiya Janata Party) government, grants facilitated naturalisation to undocumented migrants and refugees from neighbouring countries if they are Hindus or members of five other religions but does not apply to Muslims, who are instead classified as irregular migrants. In combination with the citizenship registration drive, this law thus closes an escape route into citizenship specifically for undocumented Muslims of immigrant origin (Singh and Raj 2020) who, in the past, often had access to official documents such as ration cards or voter registration that enabled them to eventually claim citizenship status (Sadiq 2009). Overall, India is much more welcoming for its diaspora than for its immigrants but has not been willing to accept dual citizenship for either category.

A third large country that illustrates another reason why the trend towards dual citizenship is not universal is Russia (see also Pogonyi's Chapter 7 in this volume). Until

12 A similar quasi-dual citizenship status was already introduced by Turkey in 1995 although, in this case, to compensate the diaspora for a ban on dual citizenship not in the country of origin (Turkey permits dual citizenship in outgoing naturalisations since 1981) but in the main host country, Germany (Çağlar 2004; Kadirbeyoğlu 2009). 
recently, Russia restricted dual citizenship for children born abroad (both parents have to be Russian citizens) and for incoming naturalisations (a previous citizenship must be renounced) but not in outgoing naturalisations. In spite of this limited toleration, Putin's regime has aggressively bestowed Russian citizenship on the nationals of disputed territories in Russia's neighbourhood, including Transnistria in Moldova, Abkhazia and South Ossetia in Georgia and the territories in Eastern Ukraine controlled by Russian-supported separatists. Russia has also provided Russian-speaking minorities in Lithuania and Estonia - many of whom became stateless after these countries regained independence in 1990 - with options to acquire Russian citizenship. In an armed intervention in Georgia in 2008, the Russian government used the pretext of a duty and right to protect its citizens abroad. In 2020, the Russian Duma dropped any pretence by almost unanimously passing a law that also extends the toleration of dual citizenship to incoming naturalisations. According to news reports, this reform is expected to create up to 10 million new Russian citizens in the other post-Soviet states. ${ }^{13}$ Although Georgia remains thus far the only case where the mass conferment of Russian citizenship preceded armed intervention instead of following it, as it did in the case of Crimea and Eastern Ukraine, this "passportisation" of territorial conflicts provides an obvious explanation for why those post-Soviet states that are concerned about Russia's geopolitical drive towards regional hegemony (Estonia, Latvia, Lithuania, Georgia and Ukraine) have resisted the global trend and do not allow for dual citizenship in either incoming or outgoing naturalisations (Shevel 2019).

A final case I want to briefly consider is Hungary. In 2001, the first government led by Viktor Orbán introduced a Hungarian Status Law that provided a quasi-citizenship status to Hungarian-language minorities in neighbouring countries (Fowler 2004). ${ }^{14}$ In 2010, the second Fidesz government abandoned Hungary's opposition to dual citizenship and offered Hungarian minorities abroad privileged access to Hungarian citizenship without a requirement to take up residence in Hungary. This move was followed in 2011 by an extension of voting rights to Hungarian citizens residing abroad that effectively secured Orbán's constitutional majority in subsequent elections. Hungary's "soft irredentism" differs from Russia's hard policy of destabilising neighbouring countries through armed interventions. Hungary's policy did, however, trigger a severe backlash against dual citizenship when Slovakia reacted to the Hungarian citizenship law of 2010 by reversing its previous toleration and revoking Slovak citizenship for those voluntarily acquiring a foreign nationality - a move which did not target emigrants but Slovak citizens belonging to the Hungarian-language minority (Bauböck 2010). More recently, it also triggered a

13 See https://www.themoscowtimes.com/2020/04/17/russia-passes-dual-citizenship-law-hoping-to-add-10m-citizens-a70036 (accessed 08 December 2020).

14 With the notable exception of Austria, as including the Hungarian minority in Burgenland province might have upset Hungary's efforts to join the European Union. 
diplomatic conflict with Ukraine, whose government is strongly opposed to the toleration of dual citizenship and protested against the handing out of Hungarian passports to ethnic Hungarians in Western Ukraine. ${ }^{15}$ Scholars analysing the Hungarian policy have argued that it was primarily driven by Orbán's concern to consolidate his domestic power by whipping up nationalist resentment about Hungary's loss of territory in the 1920 Trianon Treaty and by creating loyal Fidesz voters in neighbouring countries (Pogonyi 2017; see also his Chapter 7 in this volume).

\section{Dual citizenship as a liability?}

In the previous section, I argued that a historical or regional background of national security concerns can block moves towards the toleration of dual citizenship. The terrorist attacks of 11 September 2001 signaled a new kind of global security concern that has had a quite different impact on dual citizenship. Instead of reversing its toleration, many states have come to regard dual citizenship as an opportunity permitting them to shed responsibility for their citizens if these latter engage in terrorist activities. Revoking citizenship is a way of making (former) citizens deportable or of preventing their return to the country. The main obstacles for revocation are the international duties of states to prevent statelessness. However, withdrawing citizenship will not render the citizen stateless if the authorities can prove that she or he also possesses a foreign nationality. This generates incentives for states to engage in a vicious game of passing the buck by trying to "strip citizenship first. To the loser goes the citizen" (Macklin 2018, 171).

A probably incomplete list of legislation in liberal democracies that changed their citizenship laws to facilitate the denationalisation of convicted terrorists, terrorist suspects and "foreign fighters" includes the following cases: the United Kingdom (2002 and 2006), Australia (2007 and 2015), Israel (2008), Belgium (2012), Austria (2014), ${ }^{16}$ Canada (2014), the Netherlands (2017), Italy (2018), Germany (2019) and Denmark (2019). ${ }^{17}$

The most notorious among these is the UK, which changed its 2002 formula justifying citizenship deprivation from being responsible for acts "seriously prejudicial to the vital interests of the United Kingdom" to the Secretary of State being merely satisfied that "deprivation is conducive to the public good" in 2006. Until recently, the UK was also the only country on this list where the authorities must only have reason to assume that the person has access to another citizenship rather than having to prove that the person

15 See https://www.bbc.com/news/world-europe-45753886 (accessed 09 December 2020).

16 After the terrorist attack in Vienna by a jihadist on 02 November 2020 the government announced a further amendment that would allow the revocation of Austrian citizenship in the case of even a mere attempt to join an armed group abroad instead of the 2014 law which requires proof of armed activities abroad. At the time of writing, this reform has not yet been introduced in parliament.

17 Some of these and other cases are documented and discussed in ISI (2020). 
actually possesses a second citizenship that is recognised by the state concerned. ${ }^{18}$ In 2019, Denmark followed this example by allowing the Minister for Immigration and Integration to deprive a person of Danish citizenship if he or she does not currently possess another nationality but may acquire it through registration. ${ }^{19}$

However, there are also many countries that have resisted such policy changes because their constitutional laws or traditions do not allow the state to revoke citizenship. Among these are Poland, Spain ${ }^{20}$ and the United States (Górny and Pudzianowska 2013; Marín et al. 2015; Weil 2013). There are also cases of policy reversal and failed attempts. Under the conservative Harper government, Canada introduced a citizenship revocation law in 2014 which was repealed under Justin Trudeau in 2017. In the aftermath of the 2015 terrorist attacks in Paris, French President François Hollande proposed to extend state powers of citizenship revocation from naturalised to French-born citizens and wanted to include such powers in the constitution but the legislators could not agree on a formula that would avoid treating dual citizens and mono-citizens unequally, which was regarded as incompatible with the constitutional principle of equality of citizens.

Without doubt, the "war against terror" has caused some collateral damage to dual citizenship and it did so not by leading states to restrict access to the status but by increasing the risks for individuals who possess it. Enhanced state powers of citizenship revocation should be regarded as very problematic from both liberal and democratic perspectives (Bauböck and Paskalev 2015; Lenard 2017). Yet such a normative critique does not damage the attractiveness of dual citizenship for those who cannot imagine themselves being caught up in state operations against terrorists. Incentives for individuals to claim second and third citizenships - and incentives for states to offer these - remain strong and the numbers of multiple citizens are therefore likely to increase even further.

\section{Two scenarios about the future of multiple citizenship}

We can, however, still imagine two scenarios in which dual or multiple citizenship might be limited or reversed. The first is a scenario of self-subversion, where the ease of access to multiple passports might cause a backlash among states that try to preserve the integrity of their citizenship. The second is a scenario where globalisation itself goes into reverse gear, thereby reducing incentives and opportunities for dual citizenship.

18 In a recent decision on the best-known case, the Special Immigration Appeals Commission upheld a decision by the State Secretary to deprive Shamima Begum of her UK citizenship because it concluded that she was a Bangladeshi citizen by descent, although the Bangladeshi authorities denied that this was the case. See https://www.bbc.com/news/uk-51413040 (accessed 08 December 2020).

19 I am grateful to Eva Ersbøll for pointing this out to me.

20 In Spain, only citizens by birth can not be deprived of their citizenship. 
Peter J. Spiro has argued that the toleration of dual citizenship indicates that globalisation has irretrievably degraded the value of citizenship itself (Spiro 2016, Ch. 8). This is certainly true for states that use citizenship instrumentally in order to attract investors (Džankić 2019; Shachar and Bauböck 2014) or sports athletes (Shachar 2011). It is also true for individuals who take up these offers or use their ancestry in order to get an attractive EU passport from countries that hand out citizenship to distant descendants of their emigrants and expellees (Harpaz 2019; and Chapter 5 by Harpaz in this volume).

The devaluation-of-citizenship thesis is less plausible for international migrants with strong ties to their countries of origin and residence. For them, dual citizenship has both instrumental and intrinsic value; it enables them to move freely between the two states where they have strong family ties, property and a political stake in the future of the society. For states involved in migration chains, the toleration of dual citizenship is driven by a change in their attitude towards emigration and immigration. If they use citizenship as a tool of integration rather than exclusion, this certainly changes its content but does not diminish its value.

Yet, if multiple citizenship no longer tracks the genuine links that connect individuals to states and if there are no limits to how many passports a person can acquire, the external and domestic value of citizenship will indeed both be degraded (Bauböck 2018). It will then no longer serve to identify those states that are responsible for certain individuals in terms of protecting their rights but also in terms of taking them back or punishing them if they are involved in serious crimes. The external value of citizenship as a responsibility-sorting mechanism in the international order depends on the mutual recognition of nationality between states. It is not only undermined by states that sell their passports but also by those that revoke the citizenship of terrorist suspects in order to shift the burden of punishment to other states. Moreover, citizenship will also be devalued internally as a status of equal membership in a democratic polity if individuals without genuine ties can not only take up residence but also vote in elections. This is not primarily a question of political influence - since foreign investors often have more political influence than individual citizen voters anyway - but of the integrity of democratic elections that is corrupted if money can buy the franchise. Even defenders of multiple citizenship who do not share this normative critique of a marketisation of passports might worry about a potential backlash against dual citizenship if a sufficient number of states and voters come to regard it as a symptom of hyperglobalisation that needs to be reined in.

The second scenario is one in which globalisation itself is reversed for reasons unrelated to migration and citizenship. This chapter was written during the global Covid-19 pandemic, which triggered an abrupt closure of borders and the suspension of international as well as domestic freedom of movement. Because of the huge damage to the economy caused by even short lockdowns, this crisis is unlikely to be a sufficient cause for a lasting reversal of the growth in human mobility that has characterised the 
period of intensive globalisation since 1990. However, if the crisis lasts for much longer because vaccines are not efficiently distributed globally, an uncertain mobility value of even the most coveted passports may upset the global market for investor citizenship (Džankić 2020).

The corona crisis has hit the world during a time of heightened awareness about the longer-term and even more threatening climate crisis. It may well be that the combination of the two crises will convince many governments to slash higher taxes on air travel and to reduce reliance on global production chains by propping up the domestic or regional production of essential goods - from food to medicine and computing equipment. Such a renationalisation of the global economy could prepare the ground for changing individual behaviour and public policies resulting in a decline in global mobility, which would, in turn, depress both state supply and individual demand for instrumental citizenships. ${ }^{21}$

\section{Conclusions}

This chapter has outlined the interaction of national laws that produce dual citizenship and has used available data to illustrate the global trend towards greater toleration of this status. The main focus has been, however, on considering the limits of this trend. I have discussed three limitations: contextual reasons why some states resist toleration, the risk of citizenship revocation for dual nationals and two still largely hypothetical scenarios of the uncontrollable proliferation of multiple citizenship and of deglobalisation as an effect of pandemics and the climate crisis. Even taken together, these three limitations do not allow us to predict the demise of dual citizenship. However, if democratic citizens and states want to defend it as a progressive achievement in response to international migration, they should better strengthen the external and domestic value of dual citizenship by making it available to all those - and only those - who have genuine links to several states. Not only would this provide a justification for toleration but it would, at the same time, provide reasons for limiting access to the status to those who have good reasons to claim it.

\section{References}

Ashesh, A. and Thiruvengadam, A. 2017. Report on Citizenship Law: India. Florence: European University Institute, RSCAS/GLOBALCIT-Country Report No. 12/2017.

Bauböck, R. 2003. Towards a political theory of migrant transnationalism, International Migration Review, 37(3): 700-723.

${ }^{21}$ For a slightly different view, see Peter Spiro's Chapter 4 in this book. 
Bauböck, R. (ed.) 2010. Dual Citizenship for Transborder Minorities? How to Respond to the Hungarian-Slovak Tit-for-Tat. Florence: European University Institute, RSCASWorking Paper No. 75. https://cadmus.eui.eu/handle/1814/14625.

Bauböck, R. 2018. Genuine links and useful passports: evaluating strategic uses of citizenship, Journal of Ethnic and Migration Studies, 45(6): 1015-1026. https://doi.org/ 10.1080/1369183X.2018.1440495.

Bauböck, R. and Paskalev, V. 2015. Cutting genuine links: a normative analysis of citizenship deprivation, Georgetown Journal of Immigration Law, 30(1): 47-104.

Bauböck, R., Mantha-Hollands, A., Seubert, S., Shaw, J. and Tanasoca, A. 2019. GLOBALCIT Review Symposium on Ana Tanasoca: The Ethics of Multiple Citizenship. Florence: EUI/ RSCAS. Available at: http://globalcit.eu/review-ana-tanasoca/ (accessed 07 December 2020).

Blatter, J. 2011. Dual citizenship and theories of democracy, Citizenship Studies, 15(6-7): 769-798.

Çağlar, A. 2004. Citizenship light: transnational ties, multiple rules of membership, and the "pink card", in Friedmann, J. and Randeria, S. (eds) Worlds on the Move: Globalisation, Migration and Cultural Security. London: IB Tauris, 273-291.

Džankić, J. 2019. The Global Market for Investor Citizenship. London: Palgrave.

Džankić, J. 2020. Will the global market for investor citizenship survive Covid-19? GLOBALCIT blog. Available at: http://globalcit.eu/will-the-global-market-for-investor-citizenship-survive-covid-19/ (accessed 07 December 2020).

Faharat, A. and Hailbronner, K. 2020. Country Report: Germany. Florence: European University Institute.

Fowler, B. 2004. Fuzzing citizenship, nationalising political space: a framework for interpreting the Hungarian "status law" as a new form of kin-state policy in Central and Eastern Europe, in Kántor, Z., Majtényi, B., leda, O., Vizi, B. and Halász, I. (eds) The Hungarian Status Law: Nation Building and/or Minority Protection. Sapporo: Hakkaido University, 177-238.

Gamlen, A. 2019. Human Geopolitics: States, Emigrants, and the Rise of Diaspora Institutions. Oxford: Oxford University Press.

Goodin, R. and Tanasoca, A. 2014. Double voting, Australasian Journal of Philosophy, 92(4): 743-758. Available at: https://doi.org/10.1080/00048402.2014.913300.

Górny, A. and Pudzianowska, D. 2013. Country Report: Poland. Florence: European University Institute.

Hailbronner, K. 2003. Rights and duties of dual nationals: changing concepts and attitudes, in Martin, D. and Hailbronner, K. (eds) Rights and Duties of Dual Nationals. Evolution and Prospects. The Hague: Kluwer Law International, 19-26.

Hammar, T. 1990. Democracy and the Nation State. Aliens, Denizens and Citizens in a World of International Migration. Aldershot: Avebury.

Harpaz, Y. 2019. Citizenship 2.0. Dual Nationality as a Global Asset. Princeton: Princeton University Press. 
Honohan, I. and Erdilmen, M. 2020. Trends in Birthright Citizenship in EU 28. Florence: European University Institute, RSCAS.

Howard, M.M. 2009. The Politics of Citizenship in Europe. Cambridge: Cambridge University Press.

IOM 2019. Citizenship and Migration. International Organization for Migration, Migration

Data Portal. Available at: https://migrationdataportal.org/themes/citizenship-andmigration (accessed 07 December 2020).

ISI 2020. The World's Stateless. Deprivation of Nationality. London: Institute on Statelessness and Inclusion.

Janoski, T. 2010. The Ironies of Citizenship: Naturalization Policies in Advanced Industrialized Countries. Cambridge: Cambridge University Press.

Kadirbeyoğlu, Z. 2009. Changing conceptions of citizenship in Turkey, in Bauböck, R., Perchinig, B. and Sievers, W. (eds) Citizenship Policies in the New Europe. Amsterdam: Amsterdam University Press, 419-438.

Lenard, P.T. 2017. Democratic citizenship and denationalization, American Political Science Review, 112(1): 99-111.

Low, C.C. 2016. Report on Citizenship Law: China and Taiwan. Florence: European University Institute, RSCAS/EUDO-CIT-Country Report No. 10/2016.

Macklin, A. 2018. The return of banishment: do the new denationalisation policies weaken citizenship? In Bauböck, R. (ed.) Debating Transformations of Citizenship. New York: Springer Open, 163-172.

Marín, R.R., Sobrino, I., Martín Pérez, A. and Moreno Fuentes, F.J. 2015. Country Report: Spain. Florence: European University Institute.

MIPEX 2015. Migrant Integration Policy Index. Brussels: Migration Policy Group.

Naujoks, D. 2015. The securitization of dual citizenship: national security concerns and the making of the Overseas Citizenship of India, Diaspora Studies, 8(1): 18-36.

Pogonyi, S. 2017. Extra-Territorial Ethnic Politics, Discourses and Identities in Hungary. London: Palgrave.

Sadiq, K. 2009. Paper Citizens: How Illegal Immigrants Acquire Citizenship in Developing Countries. Oxford: Oxford University Press.

Sejersen, T.B. 2008. "I vow to thee, my countries": the expansion of dual citizenship in the 21st century, International Migration Review, 42(3): 523-549.

Shachar, A. 2011. Picking winners: Olympic citizenship and the global race for talent, Yale Law Journal, 120(8): 2088-2139.

Shachar, A. and Bauböck, R. (eds) 2014. Should Citizenship be for Sale? Florence: European University Institute, Robert Schuman Centre for Advanced Studies, EUI Working Paper. Shevel, O. 2019. The Politics of Dual Citizenship in Post-Soviet States. PONARS Eurasia Policy Memo No. 587. Available at: https://www.ponarseurasia.org/memo/politicsdual-citizenship-post-soviet-states-securing-political-goals (accessed 08 December 2020) 
Singh, K.D. and Raj, S. 2020. "Muslims are foreigners": inside India's campaign to decide who is a citizen, New York Times, 4 April.

Spiro, P.J. 2016. At Home in Two Countries. The Past and Future of Dual Citizenship. New York: New York University Press.

Tanasoca, A. 2018. The Ethics of Multiple Citizenship. Cambridge: Cambridge University Press.

Van der Baaren, L. 2020. Dual Citizenship in the European Union: Trends and Analyses (20102020). Florence: European University Institute, Robert Schuman Centre for Advanced Studies, GLOBALCIT Comparative Report No. 4/2020,

Van Oers, R., de Hart, B. and Groenendijk, K. 2013. Country Report: The Netherlands. Florence: European University Institute.

Vink, M., Schakel, A.H., Reichely, D., Luk, N.C. and de Groot, G.-R. 2019. The international diffusion of expatriate dual citizenship, Migration Studies, 7(3): 362-383.

Vink, M., de Groot, G.-R. and Chun Luk, N. 2015. MACIMIDE Global Expatriate Dual Citizenship Dataset. Harvard Dataverse, V4. Available at: http://dx.doi.org/10.7910/DVN/ TTMZ08 (accessed 08 December 2020).

Vonk, O. 2012. Dual Nationality in the European Union. A Study on Changing Norms in Public and Private International Law and in the Municipal Laws of Four EU Member States. Amsterdam: Brill.

Weil, P. 2013. The Sovereign Citizen. Denaturalization and the Origins of the American Republic. Philadelphia: University of Pennsylvania Press. 



\title{
Chapter 4
}

\section{The Past and (Post-COVID) Future of Dual Citizenship}

\author{
Peter J. Spiro, Temple University, Philadelphia
}

\begin{abstract}
Dual citizenship was once the bane of states and individuals. Today, a clear majority of states accept the status and it has become commonplace. The shift reflects changes in the nature not only of national identity but also of the individual's relationship to the state and to the world. States have almost no remaining incentive to police dual citizenship at the same time that individuals often have incentives, sometimes substantial ones, to secure it. This chapter first recounts how dual citizenship came to be normalised. It then considers how the COVID pandemic might impact on dual-citizenship opportunity structures. Although COVID may diminish the instrumental value of dual citizenship for purposes of third-country mobility privileges, it highlights the core benefit of admission rights into the country of additional nationality. Dual citizenship now becomes a kind of global health insurance as well as a way to protect mobility rights, even for those already holding premium passports. For transnational elites, these newly surfaced advantages will magnify incentives to secure investment citizenship. Others will be motivated to avail themselves of ancestral and other forms of strategic citizenship. States, meanwhile, are unlikely to see serious new costs to pre-COVID citizenship practices. Demand for dual citizenship is thus likely to rise while remaining broadly available.
\end{abstract}

\section{Introduction}

Citizenship tends towards stability. Citizenship has historically (more or less) reflected the terms of national identity which is slow in its shape-shifting. There are, of course, exceptions, as with mass extensions and deprivations of citizenship but, in most contexts, citizenship practice changes only incrementally, as a lagging indicator of gradual changes in the terms of national community on the ground. The contrast to migration policy is striking. Immigration, which regulates the terms of entry onto and presence in national territory, serves a number of functions which may be buffeted by political winds, changing conditions and immediate instrumental motivations, economic ones especially. Although citizenship and migration have been historically coupled, there have been many junctures at which careening turns in migration policies have left short-term nationality policies largely untouched.

However, slow change does not mean no change. Citizenship regimes are tectonic; one has to consider them in the long view. Dual citizenship is no exception. Taken in 
a 50-year perspective, practice relating to dual citizenship has changed dramatically. Circa 1970, dual citizenship was tolerated by only a handful of countries. It still suffered more than a whiff of the opprobrium that had been associated with the status through the middle of the twentieth century, an opprobrium that once weighed heavily on it as something immoral. Today, a clear majority of states openly accept the status and it has become commonplace. The shift reflects changes in the nature not only of national identity over those years but also in the nature of the individual's relationship to the state and to the world. States have almost no remaining incentive to police dual citizenship at the same time that individuals often have incentives, sometimes substantial ones, to secure it. Although perceptions of the status are country-contingent, far from its prior, somewhat dodgy associations, dual citizenship has emerged as a status symbol in many contexts, a status to be advertised rather than concealed (Harpaz 2019; see also his Chapter 5 in this volume).

Will this shift to normalised dual citizenship prove durable? The COVID-19 global pandemic will test the resilience of many facets of globalisation. The immediate consequences on immigration of COVID-19 have been acute and profound. Most countries imposed severe COVID-related restrictions on the in-movement of persons. Visa services were put on hold. Formal restrictions were reinforced by the near-disappearance of scheduled air transport. Much of the world was put on lockdown. One can expect many of these restrictions to stay in place even as vaccines are rolled out. Among those countries that manage to put a lid on the disease, there may be new constellations of revived mobility. However, normalising global movement to anything like the pre-COVID era looks like a long path.

Citizenship practices and policies are less obviously impacted. Traditional naturalisation should be unaffected to the extent that most applicants, for the short term at least, are already territorially resident. Dual citizenship might be different. Because citizenship status is coupled with entry rights, one might expect states to suppress dual citizenship among those of their non-residents lacking thick affective ties. Countries might change their view of these instrumental citizens, especially if they end up on their doorsteps instead of someone else's. One might also expect individuals to be less interested in acquiring additional citizenships to the extent that third-country travel privileges are no longer part of the citizenship package; if non-resident citizenship in a country no longer promises visa-free travel and settlement privileges, it might no longer be worth the trouble. Supply and demand may shift. Nevertheless, short of full deglobalisation and a sustained lockdown, citizenship is likely to remain a valuable asset at the same time that states are unlikely to see serious new costs to pre-COVID citizenship practices. The pandemic is unlikely to reverse a long progression towards the state acceptance of dual citizenship and individual interest in acquiring it.

This chapter first sets out a short history of dual nationality and its trajectory from universal opprobrium to wide acceptance. States once had a mutual interest in suppressing 
the status to the end of managing interstate relations, through which national identities were hardened and segmented. As dual citizenship came to pose a less-grave threat to peaceful relations, the opprobrium eased. Only with globalisation and the blurring and demotion of national identities did the toleration shift to acceptance. The chapter then turns to the possible consequences of COVID-19 on this acceptance. To the extent that the pandemic results in partial deglobalisation and the reinforcement of home, it might be expected to reverse the normalisation of dual citizenship. This seems unlikely, however, as states will have little incentive to clamp down on the status at the same time that individuals will come to see novel advantages to holding dual citizenship, including as a kind of global health insurance.

\section{Dual nationality as a threat to world order}

I have told the story of dual citizenship at length and in brief elsewhere (Spiro 1997, 2007, 2010, 2016, 2017, 2019). Two threads explain dual citizenship's transformation: an interests-oriented exposition - considering the question from the perspective of states and individuals - and an identitarian explanation, through which dual citizenship supplies a lens to the meaning of membership in the national community. Both are, to a large extent, materialist in the sense that they flow from shifts in context. I do not mean necessarily to celebrate the status. The description is determinist rather than triumphalist in the sense that changes in world orderings have made the shift towards accepting dual citizenship inevitable and, in all likelihood, irreversible.

The interests-oriented perspective starts with the premise that manpower was once the fount of sovereign strength. Power was importantly correlated to military manpower. Of course, other factors were in play but the number of men who could be mustered to arms was a central determinant of a state's place in the early-modern pecking order. Before the age of migration, the aggrandisement and diminution of this power was typically accomplished by the acquisition or loss of territory (by force or marriage) along with the inhabitants therein. To the extent that the nation became an appropriate frame of association, the national affiliation of individuals flowed from territorial location, which was unlikely to change during the life of the average individual. The determination of nationality was not a difficult undertaking, to the point where it is arguably anachronistic to use the term at all - nationality simply was not an issue. Naturalisation was highly exceptional - dual nationality was essentially non-existent.

Once migration became a significant phenomenon, with the opening up of the New World, nationality's sorting function became more complex. War was important to building a sense of nationhood (Haller 2009). European sovereigns tolerated emigration as a partial remedy for economic, social and/or political difficulties and, in any case, lacked the apparatus to achieve effective exit control. However, population was considered a scarce resource and states particularly did not want to lose potential soldiers (Zolberg 
2007). To that end, they refused to recognise transfers of nationality. States of origin refused to recognise the legitimacy of naturalisation before another state, even in the face of the individual's permanent resettlement, while the new state of residence looked to migrants to add to their own military strength.

The result was chronic and intense diplomatic disputes as each state of nationality claimed individual migrants as their own. The paradigm case involved a male migrant to the United States returning to his homeland only to face conscription or punishment for failure to satisfy military-service requirements. Claims on the part of the state of origin triggered diplomatic protection on the part of US authorities. Difficult as it may be to grasp the magnitude of this problem from our contemporary vantage point, this was a major irritant to relations between the United States and most major European sovereigns through the nineteenth and into the twentieth century. Dual nationality was a defining predicate of the difficulty. The refusal of the birth sovereign to allow the termination of nationality coupled with the acquisition of nationality through naturalisation gave rise to double nationality (as it was then denominated) and the obligations that came with it. Each of two sovereigns claimed the individual for purposes of military service - claims that inevitably resulted in serious bilateral conflict. The status came to be considered a bane of the international system (Salyer 2018; Spiro 2016).

Dual nationality made even less sense in terms of the individual's conceptual place in the world order, such as it existed. It is difficult to speak of national community in the early-modern period. However, the individual's relationship to his sovereign was central to individual identity (again, to the extent that it is appropriate to speak of identity as such for this time). The individual's connection to a sovereign was thought to be part of the natural order of things, a key link in the Great Chain of Being. This was a matter of birth, not choice. "Once a subject, always a subject" supplied the foundational principle of nationality. This was coupled with absolute duties of loyalty. Answerable only to God, the sovereign could do as he wished with his subject. This regime of "perpetual allegiance" was conceptually incompatible with dual nationality. It was also incompatible with the transfer of nationality; it supplied ideological grounds for sovereign refusals to recognise the legitimacy of naturalisation elsewhere. On the receiving end, it explains the vocabulary of after-acquired nationality. Sitting as a dead metaphor to contemporary ears, the term "naturalisation" implies an individual rebirth (to make natural), the only way the mechanism could be rationalised with perpetual allegiance.

The downside of dual nationality for individuals mirrored that for states. The failure of origin states to recognise transfers of nationality created onerous or conflicting obligations, especially with respect to military service (Bar-Yaacov 1961). To the extent that nationality now implicated agency (through the acts of migration and naturalisation), one can more confidently characterise national affiliation as having encompassed identity. It was an exclusive identity. The diversity of national systems in many cases did not permit coterminous membership; one could not be a faithful adherent of both monarchical and 
democratic systems at the same time. Individuals took loyalty seriously, in any case. They sought not to accumulate nationalities but to substitute them, in a way that reflected changed life circumstances. Emigrants maintained sentimental ties to their homelands (in some cases, they did not naturalise and, in others, they returned to their countries of origin, in which case the native identity reverted). Nevertheless, in the dominant template, migrants would have looked to acquire nationality in the country of resettlement and shed that of their country of origin.

The antidote from both the state and individual perspectives was to accept such transfers of nationality. For states, the shift was a recognition that emigrants were lost to military service and that the diplomatic costs outweighed the benefit of keeping emigrants on the national rolls. (Even so, acceptance among states was balky. The UK led the way in 1870 and most major states had followed suit by the 1920s but some number of states - Iran and most Arab countries, for example - continue to hew to perpetual allegiance even today.) This was emphatically not an acceptance of dual nationality; on the contrary, the new practice built on its rejection with mechanisms to suppress it. Under the new norm, nationality was terminated upon naturalisation in another state and it forced those born with the status to choose one at majority. For the individual, the shift was framed as a vindication of the "right to expatriation" (Salyer 2018). This was a right to transfer formal national affiliation along with that of social and affective ties. To the extent that the regime was leaky, it was backstopped by strong social norms against the status and the reification of national identity. Bigamy was the standard analogy. US President Theodore Roosevelt, for example, derided dual nationality as a "self-evident absurdity".

\section{Tolerating dual nationality}

The alignment of state and individual interests and identity persisted through the mid-twentieth century. The regime began to erode with the rise of human rights in the wake of World War II, which defused the threat which dual nationality posed to bilateral relations. States became less aggressive in policing the status. Individuals started to have a marginal interest in maintaining the status and less of an incentive to shed it, although norms backstopping singular loyalty proved sticky. However, it was not until the dawn of globalisation that the balance of interests and identity turned more clearly to the acceptance of dual citizenship. The blurring of national identities and the emergence of substantial benefits in the status laid the foundation for its rise.

From the perspective of states, dual nationality no longer posed significant worldorder costs. This was partly contingent, partly systemic. The suppression regime eliminated the problem in a number of important pairings. After the UK legislated, in 1870, the termination of nationality upon naturalisation elsewhere, for example, bilateral difficulties with the United States were largely eliminated. Many continental states followed suit 
with the so-called Bancroft treaties with the United States. The US itself set up an expatriation mechanism to terminate the citizenship of individuals who activated another citizenship, thus addressing the high incidence of dual citizenship among those born in the United States to immigrant parents (Weil 2012). For example, a person born in the US with an alternative birth citizenship automatically lost US citizenship upon enlistment in a foreign armed force.

After World War II, disputes were further diminished by Cold War alignments. NATO and other Western-bloc countries established a web of bilateral and then multilateral agreements to govern military-service obligations among dual nationals, limiting conscription to the state of habitual residence (Legomsky 2003). This eliminated the most important disincentive for the status. Dual nationality across the Iron Curtain, meanwhile, was not a problem. Those who escaped the Eastern Bloc did not go back and, in many cases, were stripped of their origin citizenship; dual nationals were not an independent cause of friction.

Perhaps more importantly, the advent of human rights shifted the logic of sovereignty. Before human rights, states could treat their nationals as they pleased but were constrained in the treatment of nationals of other states. Dual nationality confounded that symmetry. It presented a subclass of subjects for whom a sovereign was answerable to another sovereign, presenting inevitable irritants to interstate relations. With the adoption of a postwar human-rights regime, however rudimentary, dual nationals were no longer distinctive in this respect. States were now answerable to other states with respect to the treatment of all of their own nationals, whether mono or dual. The fact that a subject also had another nationality did not make him a peculiarly probable point of bilateral contention, at least not in a nineteenth-century way.

States also found themselves hemmed in by international law constraints advancing sex equality in nationality practice. During the nineteenth century and into the twentieth, most states automatically terminated the nationality of women upon marriage to foreign men. The practice was consistent with prevailing notions of patriarchy and a belief that the family should not bridge national divides. However, it had also been motivated as a mechanism for suppressing a source of dual nationality that would otherwise result from such mixed marriages, at least as long as some states automatically extended nationality to foreign women marrying male nationals (Irving 2016). This sex discriminatory approach was countered by a series of international agreements, culminating in the 1957 Convention on the Nationality of Married Women, which barred non-consensual changes of nationality on the basis of marital relations.

States, nonetheless, continued to disfavour dual nationality in the face of persistent understandings of nationality implicating loyalty and allegiance, though dual nationality never presented a serious national security issue. Nor did they or individuals have much incentive to facilitate the status. There was no understanding of strategic dual citizenship on the part either of states or of individuals. 
Positive incentives emerged in more recent decades. For some states, dual citizenship became a way to cement ties with powerful diasporas. For sending states of the global South, where emigrants had once been seen as traitors to their homelands, they were now (through remittances and other economic contributions) understood as economic superheroes (see, for example, Fitzgerald 2008). Dual citizenship presented a costless tool by which to maintain cross-border solidarities. Home countries had an interest in their external nationals naturalising in their countries of residence by way of securing the benefits and security of citizenship, as well as exercising political power. The result was a wave of migrant source-states amending nationality laws in the 1990s, allowing the retention of nationality upon naturalisation in another country.

The shift in state incentives was also responsive to individual demand. Some of this demand has been rooted in the practical elements of cross-border lives. Diasporas chafed at having to secure visas to return home and at being subject to citizen-only restrictions on property ownership. They also looked to maintain a say in homeland politics (as more countries allowed dual citizenship, more also allowed non-resident voting). With remittances came power. When emigrant communities lobbied for the acceptance of dual citizenship, homeland governments had to listen and many responded.

The demand also reflected shifts in identity. Enabled by cheap travel and the Internet, migrants could sustain close ties with families back home. Even as they set down permanent roots in countries of relocation, their affections remained focused on their origin countries. Many thought to retire back home (even if, in the end, most did not). Loyalty no longer posed the same sorts of conflict as in the past; one could now have two nationalities without being forced to choose between them on most policy issues (much less armed conflict). As most states abandoned military-service obligations (Tarabar and Hall 2016), there was little cost to acquiring a new citizenship while keeping the old. Diaspora members also looked to maintain the homeland tie to pass the identity on to their children. This has become true even for external citizens of developed countries. Though immigrant-receiving European states had fewer incentives to accept dual citizenship than sending states, many have relented to calls from their own external citizen communities. Native-born Europeans who may have married nationals of other states and permanently relocated to other OECD countries increasingly want to keep their birth citizenship when naturalising in their new states of residence - and origin countries are acceding to the preference. A ratchet effect then comes into play; once states have acceded to external populations, they have a harder time resisting calls to accept dual citizenship for resident immigrants.

\section{The new, new dual citizenship}

These permutations of interests and identity on the part of states and individuals are continuous in one important respect: they consider individuals who have a meaningful 
sociological connection to the state. That was the 1990 s version of dual citizenship. The 2000 s witnessed the rise of a new type of dual citizenship in which individuals acquired a second citizenship in a state of non-residence to which they had thin or even non-existent ties. There have been two notable mechanisms for this kind of citizenship: ancestry and investment. Ancestral citizenship implicates the extension of citizenship iure sanguinis on the basis of ancestry further removed than a parent. Investment citizenship programmes offer citizenship for sale.

Instrumental incentives play more clearly with respect to these citizenships. They have been tied to the increasing value of global mobility privileges. Citizenship through a good part of the late-twentieth century was not worth much beyond the state in which it was held. That changed as countries bifurcated their immigration policies, favouring some passports with visa-free entry privileges, while disfavouring others with increasingly formidable visa requirements. Citizenships correspondingly bifurcated for their third-country value, with some promising upgrades to facilitated global travel - a ticket to the (sometimes literal) fast lanes. With this new benefit, dual citizenship became attractive in non-immigration, non-diasporic contexts. This kind of dual citizenship was not about maintaining ties with the country in which one was born but about having a leg up in the global economy and unencumbered access to world destinations (Surak 2020).

The ancestral citizenship phenomenon is increasingly well documented. Tens of thousands of Argentine and Chilean citizens claimed Spanish and Italian citizenship in the early 2000 s on the basis of their grandparents. In the face of a Latin American financial crisis, the acquisition in many cases was motivated by the economic opportunities that came with EU citizenship (Cook-Martín 2013). Serbians have claimed Hungarian citizenship as an EU entrée; Israelis have claimed a range of European citizenships, for both mobility and status purposes; pregnant women travel to the United States to secure birthright US citizenship for their children (Harpaz 2019). Citizenship, in these cases, is acquired on a non-resident basis. In some cases, it may have an affective element, actuating a sentimental ancestral tie. Some of those Argentines may really feel Italian, in a meaningful way. No doubt co-ethnics who have acquired Hungarian citizenship often have substantial sociological ties to Hungary through lineage and culture. However, some are acquiring the extra citizenship for purely instrumental reasons.

This is more obviously the case for investor citizens. Investor citizens have been looking primarily for the mobility privileges that come with the extra citizenship (Surak 2020). They are priced accordingly. Malta and Cyprus set the gold standard because their citizenship affords holders settlement rights in the rest of the EU and visa-free travel throughout the world. Citizenship in such island states as Dominica and St Kitts and Nevis comes with visa-free access to the EU. These programmes depend on dual citizenship and citizenship differentials. Very few would relinquish an existing citizenship for a new one in a country to which they have no intention of relocating. The incentive is provided by the differential value between the existing and the investment citizenship. As a Russian 
or Chinese national, global mobility is encumbered. Citizenship in Malta or St Kitts and Nevis adds a value that (for the rich) is worth paying.

These strategic citizenships have also benefited states. Some states use ancestral citizenships to reify ethnic identities. In some cases, it has been put to work for electoral purposes, with Hungary supplying the most notable example (Pogonyi 2017). It has been a cheap way to atone for past sins, as with Germany's "restoration" of citizenship stripped by the Nazi regime or the more attenuated extension of citizenship to the descendants of Sephardic Jews expelled from Portugal and Spain in 1492. In all these cases, states may also be sorting for what they perceive to be assimilable migrants under cover of nationality policy (FitzGerald 2017). Spain and Portugal did not offer citizenship to the descendants of Moors expelled in 1492, after all.

As for investor citizenship, the benefits for some states is clear. Investor citizenship programmes reap substantial revenues at low marginal cost. For large economies, the programmes are arguable; even if successful, the revenues would not be proportionally significant. For some smaller states, by contrast, investment citizenship can account for a sizable proportion of government revenues. Investor citizenship activity has accounted for as much as 35 per cent of St Kitts' GDP, for example (Abrahamian 2015). As with natural resources, there are risks of mismanagement, as well as sustainability questions, especially in the face of increased competition (Xu, El-Ashram and Gold 2015). Nevertheless, investor citizenship programmes have proved a boon to a number of countries.

These new instantiations of dual citizenship are also congruent with changing, though contested, conceptions of citizenship. Ancestral citizenship works on the premise that national identity, however remote, can be actualised with full citizenship. It is (in effect) equating citizenship with membership in an affinity association. "Yes, I feel a little bit Irish because I have a grandfather who was born there, so I should be able to sign up for the club". This version of citizenship does not sit well with prior framings centering on loyalty and allegiance, framings that elevated the state above other forms of association.

Investor citizenship poses a more frontal challenge to these historical conceptions, shearing them of their near-sacred radiations. Citizenship has long been distinguished by its positive normative connotations. Investment citizenship not only dissolves those favourable associations but actually reverses them. Citizenship loses the implication of shared fate, mutual support and community trust and becomes just another incident of neoliberal consumerism.

This explains why investment citizenship has become a flashpoint in scholarly commentary (Shachar 2017). Even though the numbers are small, investment citizenship has triggered intense normative critique. No doubt investment citizenship is contested but the very fact that it exists as a non-trivial phenomenon - normalised, in effect - reflects a changed conception of citizenship. Roman citizenship could be bought, as could membership in early Renaissance city-states (Džankić 2019). At the apex of national identity during the twentieth century, however, the idea that one could buy an extra citizenship in 
order to reap its benefits would have been considered nonsensical, perhaps outrageous. Today it has spawned an industry. Though some will continue to reject investor citizenship on ideological grounds, its acceptance by others evidences a shift in contemporary understandings of citizenship as an institution.

\section{Enter COVID-19: dual citizenship as health insurance}

That is where things stood before the end of 2019, with dual citizenship supplying a strategic tool for states and individuals as well as reflecting a changed understanding of citizenship generally. Then came the COVID-19 pandemic, which has destabilised the world in many respects, mobility perhaps the most notably among them. As of June 2020 , most countries of the world were on near-complete lockdown. Will the pandemic reduce the appetite for dual citizenship? Perhaps. It is more likely to shift the material incentives for the status than extinguish them.

Of the three sources of dual citizenship - those who receive it at birth, those who naturalise after migrating and those who naturalise without migrating - the first two categories are unlikely to be much affected by the pandemic. Those who receive dual citizenship at birth typically do so automatically, so there is no agency involved. The incentives for naturalising in a state after resettling there are largely unchanged. If anything, there will be more reason to naturalise, insofar as there is any doubt about locational security. Migrants will look to formalise their right to remain and re-enter the country of naturalisation in the event of a subsequent pandemic or other emergency event, especially if they are able to retain their citizenship of origin. That added incentive will be marginal, as most countries appear to have excepted residents from entry restrictions although a rational immigrant could well see an added insurance value to acquiring citizenship.

Possible elasticity is found mostly in the last category - those who naturalise without migration through ancestral or investment citizenship. As discussed above, third-country mobility privileges have supplied an important incentive for non-resident naturalisation. These mobility benefits have been compromised by COVID-19. Citizenship in St Kitts will not get a person into the EU when a pandemic takes hold nor, for that matter, will a US passport. An EU passport would not for that moment facilitate travel to the United States; it might not even guarantee entry into other EU countries. Travel and settlement rights - which figure in recent passport rankings systems, most notably from the investor citizenship broker Henley and Partners - were severely compromised. This could affect the demand for non-resident citizenship.

However, at least in one obvious respect, the value of secondary citizenships is enhanced by the COVID situation and the prospect of future pandemics. In most cases, citizenship in a state still guarantees a person entry into that state. Even most (though not all) countries that have adopted total entry bans have excepted nationals from the 
scope of the ban. That may not have seemed like much, pre-COVID. Today, being able to enter Malta or Cyprus or even St Kitts may look like a valuable escape hatch to potential investment citizens. For the very rich, the price tag is nominal. What good does a private jet do you if you have no place to go? As Surak (2020) describes it, the rich see investor citizenship as a matter of accumulating options and "Plan Bs". Like insurance in other, more quotidian realms, having the extra citizenship imparts a sense of well-being even if you never end up having to collect on it.

The same may go for those with ancestral and other nominally established qualifications for citizenship. It is well established that insurance against political risk is an important motivation for acquiring non-resident citizenship (Knott 2019). Now we might speak of insurance against health emergencies. Individuals will see this as a benefit of securing an additional citizenship. It may or may not be rational - who knows whether the country in which a person's grandparent was born will be a shelter from the next pandemic storm - but the additional citizenship and entry rights into that single country will supply value and, in most cases, cost little if anything.

Moreover, travel and settlement privileges will almost certainly be restored at some point, at least in some constellations. Although COVID-19 probably presents the most serious threat to free movement in the European Union's history, it is unlikely to shut it down on a permanent basis. Pre-COVID visa-free travel between other states will be restored, at least among countries that have eradicated the virus. In the run-up to COVID-19, in the first quarter of 2020, demand for investor citizenship reportedly grew by over 40 per cent. Most of the recent entry restrictions will be lifted as the vaccine is widely administered. Global travel is unlikely to return to its recent capacity for many years although mobility privileges may. Citizenship is a longer-term investment (literally or not); many individuals who acquire a second citizenship do so not to facilitate shortterm plans but, rather, to expand life opportunities, sometimes intergenerationally. It will take more than an outlier moment to erase that perception.

\section{The low cost of pandemic citizenship}

Sustained demand for extra citizenships will be meaningless if states opt to suppress the status. This seems unlikely. There is no COVID-related cause for reversing the acceptance of dual citizenship with respect to those born with the status or those who naturalise as residents. Even with respect to non-resident naturalisation, states will have little justification for constraining the citizenship of those with "genuine links" to a state, in the framing of such prominent theorists as Rainer Bauböck (2018) and Ayelet Shachar (2009). They will also have a hard time distinguishing those who have genuine links from those who do not. The one context in which such sorting is more readily undertaken - investment citizenship - is also unlikely to be scaled back. Dual citizens do not cost states very much, even under pandemic conditions. 
The pandemic demonstrates the continuing strong pull of national identification. More accurately, perhaps, it shows the continuing salience of home even in the face of globalisation. As the pandemic unfolded on a global basis, many people went back home - not only those who were travelling abroad as tourists but also those who had been resident abroad. That seemed natural. There were few objections to permitting the re-entry of these individuals (there may have been issues relating to quarantine but that is a separate matter). Amidst the nationals who were excepted from entry bans, there will have been some instrumental citizens, those who were not returning home but who were seeking refuge from their dangerous places of residence and primary citizenship those who were seeking refuge from home rather than returning to it.

However, one supposes that they were not that many and, in any case, not so many as to pose any significant burden on the state of non-resident citizenship. Because of the global nature of the pandemic, the value of being in one country over another (with very few exceptions, like New Zealand) has been relative. It is not like fleeing a war zone for a peaceful zone. However much an American with an instrumental EU passport might have been tempted to relocate there, say to Germany or Austria, it would have been a difficult time to establish residence - to make a home - because those places were under lockdown, too. By way of some evidence (and supporting the contrast to those trying to escape conflict) there has been no carping about "Canadians of convenience" and the like being evacuated from trouble spots courtesy of the state, as happened when Canada spent millions rescuing thousands of dual Lebanese-Canadians caught up in the 2006 conflict between Israel and Hezbollah (Nyers 2010).

Even if some individuals have exploited instrumental citizenships for entry purposes in the face of COVID-19, they posed no different a health hazard than mono- or dual nationals who were returning to their real homes. So long as containment remains a possibility, all entrants pose a risk, which will be variable according to travel history and other factors - dual citizenship not among them. The entry of large numbers of non-resident citizens could burden quarantine capacities. If, for instance, large numbers of non-resident Irish citizens had decided to take advantage of the status and relocate to Ireland as the pandemic unfolded, that would have been a problem. However, there appear to have been no major instances in which states chafed at admitting non-resident dual citizens as they locked down borders against non-citizens. It is unlikely that governments will look to suppress dual citizenship preemptively as a measure against future global health emergencies.

For states with investor citizenship programmes, the balance is clear-cut. As economies crater everywhere, governments will be hard pressed to maintain revenue levels. If investor citizenship was important to some economies pre-COVID, it will be all the more important today. This will be especially true for those Caribbean states whose economic lifeblood, tourism, has evaporated almost overnight. Countries with investor citizenship programmes will now have to contemplate recipients who will actually go to live with 
them - there has always been that fiction, at least. The numbers are small enough that protective health measures can be put to work to protect against the minimal added risk of entrants numbering in the hundreds at most. If anything, the scope of investment citizenship may broaden as states whose passports never offered much in the way of global travel rights can at least offer a shelter from spreading disease.

\section{Citizenship after COVID-19}

COVID-19 is unlikely to reverse the decades-long move to accept dual citizenship. Will it change citizenship in other ways? Perhaps. The fight against the virus may revive some citizenship solidarities. To the extent that everyone feels "in it together" and to the extent that the state is a key part of the answer, citizenship could enjoy a comeback. However, both of these conditions look empirically variable. In some countries - the ones that succeeded in putting a lid on infections - there should be a revival of constructive nationalist sentiment. In countries like South Korea, New Zealand, Taiwan, Denmark, Austria and (perhaps) Germany, one can expect a deserved sense of national pride. Citizenship in those countries may take on new affective and instrumental value. In others - the US, the UK, Italy, France, Russia, Brazil - maybe not so much. The US, particularly, is riven by political and other divisions, which COVID-19 appears to be compounding. The failure of the federal government to muster even a semi-competent, bipartisan response is likely to accelerate a growing sense that the United States is losing coherence.

Perhaps subnational solidarities will be reinforced where national ones fray. The coronavirus is global but, of course, is territorial and spatial in its impact and transmission. One has to count on neighbours at least to be responsible - to be "good citizens" in an everyday sense. How that maps onto the formal institution of citizenship remains to be seen.

\section{References}

Abrahamian, A. 2015. The Cosmospolites: The Coming of the Global Citizen. New York: Columbia Global Reports.

Bar-Yaacov, N. 1961. Dual Nationality. London: Stevens.

Bauböck, R. 2018. Democratic inclusion: a pluralist theory of citizenship, in Bauböck, R. (ed.) Democratic Inclusion: Rainer Bauböck in Dialogue. Manchester: Manchester University Press, 3-102.

Cook-Martín, D. 2013. The Scramble for Citizens: Dual Nationality and State Competition for Immigrants. Stanford: Stanford University Press.

Džankić, J. 2019. The Global Market for Investor Citizenship. London: Palgrave Macmillan. FitzGerald, D. 2008. A Nation of Emigrants: How Mexico Manages Its Migration. Berkeley: University of California Press. 
FitzGerald, D. 2017. The history of racialized citizenship, in Shachar, A., Bauböck, R., Bloemraad, I. and Vink, M. (eds) The Oxford Handbook of Citizenship. Oxford: Oxford University Press, 129-152.

Harpaz, Y. 2019. Citizenship 2.0: Dual Nationality as a Global Asset. Princeton: Princeton University Press.

Haller, M. 2009. The nation state and war, Schweizerische Zeitschrift für Soziologie/Swiss Journal of Sociology, 35(1): 11-30.

Irving, H. 2016. Citizenship, Alienage, and the Modern Constitutional State: A Gendered History. Cambridge: Cambridge University Press.

Knott, E. 2019. Strategy, identity or legitimacy? Analysing engagement with dual citizenship from the bottom-up, Journal of Ethnic and Migration Studies, 45(6): 994-1014.

Legomsky, S.H. 2003. Dual nationality and military service: strategy number two, in Martin, D.A. and Hailbronner, K. (eds) Rights and Duties of Dual Nationals. Leiden: Brill, 79-126.

Nyers, P. 2010. Dueling designs: the politics of rescuing dual citizens, Citizenship Studies, 14(1): 47-60.

Pogonyi, S. 2017. Extra-Territorial Ethnic Politics, Discourses and Identities in Hungary. London: Palgrave.

Salyer, L.E. 2018. Under the Starry Flag. Cambridge, MA: Harvard University Press.

Shachar, A. 2009. The Birthright Lottery: Citizenship and Global Inequality. Cambridge, MA: Harvard University Press.

Shachar, A. 2017. Citizenship for sale? In Shachar, A., Bauböck, R., Bloemraad, I. and Vink, M. (eds) The Oxford Handbook of Citizenship. Oxford: Oxford University Press, 789-809.

Spiro, P.J. 1997. Dual nationality and the meaning of citizenship, Emory Law Journal, 46(4): 1411-1485.

Spiro, P.J. 2007. Dual citizenship: a postnational view, in Faist, T. and Kivisto, P. (eds) Dual Citizenship in Global Perspective. New York: Palgrave Macmillan, 189-202.

Spiro, P.J. 2010. Dual citizenship as human right, International Journal of Constitutional Law, 8(4): 111-130.

Spiro, P.J. 2016. At Home in Two Countries: The Past and Future of Dual Citizenship. New York: New York University Press.

Spiro, P.J. 2017. Multiple citizenship, in Shachar, A., Bauböck, R., Bloemraad, I. and Vink, M. (eds) The Oxford Handbook of Citizenship. Oxford: Oxford University Press, 621-640.

Spiro, P.J. 2019. The equality paradox of dual citizenship, Journal of Ethnic and Migration Studies, 45(6): 879-896.

Surak, K. 2020. Millionaire mobility and the sale of citizenship, Journal of Ethnic and Migration Studies, 46: forthcoming.

Tarabar, D. and Hall, J. 2016. Explaining the worldwide decline in the length of mandatory military service, 1970-2010, Public Choice, 168(1): 55-74. 
Xu, X., El-Ashram, A. and Gold, J. 2015. Too Much of a Good Thing? Prudent Management of Inflows Under Economic Citizenship Programs. Washington, DC: International Monetary Fund, Working Paper WP/15/93.

Weil, P. 2012. The Sovereign Citizen: Denaturalization and the Origins of the American Republic. Philadelphia: University of Pennsylvania Press.

Zolberg, A. 2007. The exit revolution, in Green, N.L. and Weil, F. (eds) Citizenship and Those Who Leave. Urbana-Champaign: University of Illinois Press, 33-60. 



\title{
Chapter 5
}

\section{Strategic Dual Citizenship: Global Dynamics of Supply and Demand}

\author{
Yossi Harpaz, Tel-Aviv University
}

\begin{abstract}
The growing toleration of dual citizenship changes the basic rules governing citizenship attribution. It creates new possibilities for legal connections between states and individuals, including overlapping memberships and belonging from a distance. In this chapter, I argue that the legitimisation of dual citizenship leads to the adoption of strategic policies on the part of states (the "supply" side) as well as on the part of eligible individuals (the "demand" side). Numerous states use dual citizenship policies to select new citizens that do not live on their territory and do not intend to relocate or give up their original citizenship. These include the descendants of emigrants (e.g. Italian descendants in South America who are now offered Italian citizenship), cross-border co-ethnics (such as ethnic Hungarians in the countries surrounding Hungary), as well as millionaires from developing countries who can now - for a hefty sum - acquire citizenship from a country where they have never set foot. From the perspective of eligible individuals, such schemes offer opportunities to strategically expand their scope of rights and opportunities by acquiring a second citizenship that is ranked higher in the global hierarchy of citizenship value. The expected benefits may include global travel freedom, an insurance policy and broader economic opportunities. These developments, which impact both states and individuals, weaken the traditional association between citizenship and national identity.
\end{abstract}

\section{Introduction}

Tolerance of dual citizenship has become the global norm since the 1990s. Historically, the idea that an individual could belong to two countries was perceived as an anomaly, even an abomination. In recent years, however, dozens of countries have revised their citizenship laws to permit it. To understand these legal changes more fully, we need to go behind the laws and inquire about the political and economic conditions that led governments to legitimise - and even encourage - dual citizenship and about the incentives that drive individuals to seek it.

In this chapter, I argue that governments and individuals have used dual citizenship strategically. Dual-citizenship policies expand the boundaries of the nation to include populations who are perceived as having potential value, which may be symbolic, electoral, demographic, territorial or economic. From the perspective of individuals, a key 
motivation for acquiring dual citizenship is the wish to benefit from the additional rights and security that accrue to holders of top-tier citizenship from rich Western countries. The freedom to travel, in particular, has become a coveted global resource that many seek to secure through the possession of a second passport. Dual citizenship is part of a global trend toward an increasingly strategic and instrumental understanding of citizenship (Harpaz and Mateos 2019; Joppke 2019).

The rest of this chapter will continue as follows. In the next section, I discuss the growing legal toleration of dual citizenship. I then survey some of the key ways in which governments have used dual-citizenship policies, before moving on to the demand side of dual citizenship, outlining the structure of global inequality that explains individuals' incentives to acquire it. Finally, I present comparative statistics on the prevalence of dual citizenship that illustrate the key role of global inequality in shaping how dual citizenship is used and understood.

\section{The rise of dual citizenship}

For most of the nineteenth and twentieth centuries, countries typically prohibited dual citizenship and made significant efforts to suppress it. The ban on dual citizenship was enforced through a combination of bilateral treaties, international conventions and attempts by individual states to monitor their citizens. Seen as an anomalous condition, dual citizenship was famously compared to bigamy (Shuck 2002; Spiro 1997, 2015; Weil 2011). This state of affairs has changed dramatically since the 1990s. A new permissive approach to citizenship became popular, as dozens of countries waived the traditional requirement for exclusive citizenship.

Figure 5.1 presents the citizenship policy of 88 countries in the Americas, Europe, Oceania and Asia (data for the Middle East and Africa were not available). The graph shows the percentage of countries in each region that permitted dual nationality in 1990 and 2016 in cases of the voluntary acquisition of a foreign nationality or of the acquisition of the country's own citizenship by naturalisation.

Figure 5.1 illustrates the shift in states' acceptance of dual nationality: in 1990, only 28 per cent of the countries in the sample tolerated it; by 2016, it was accepted by 75 per cent of those countries (see also Vink et al. 2019). This represents a dramatic change in the relation to a legal status that until recently was considered highly problematic, even scandalous. Over the past three decades, the toleration of dual nationality has grown across all the different regions, albeit at different paces. Anglophone settler countries and Western Europe were "early adopters" of multiple citizenship permission. ${ }^{1}$ By 1990, the United States, Canada and New Zealand already permitted dual citizenship; Australia joined them in 2002. In Western Europe, about 30 per cent of countries permitted dual

\footnotetext{
1 The same goes for former British colonies.
} 


\section{Figure 5.1. Regions by percentage of countries that permitted dual citizenship in 1990, 2016'}

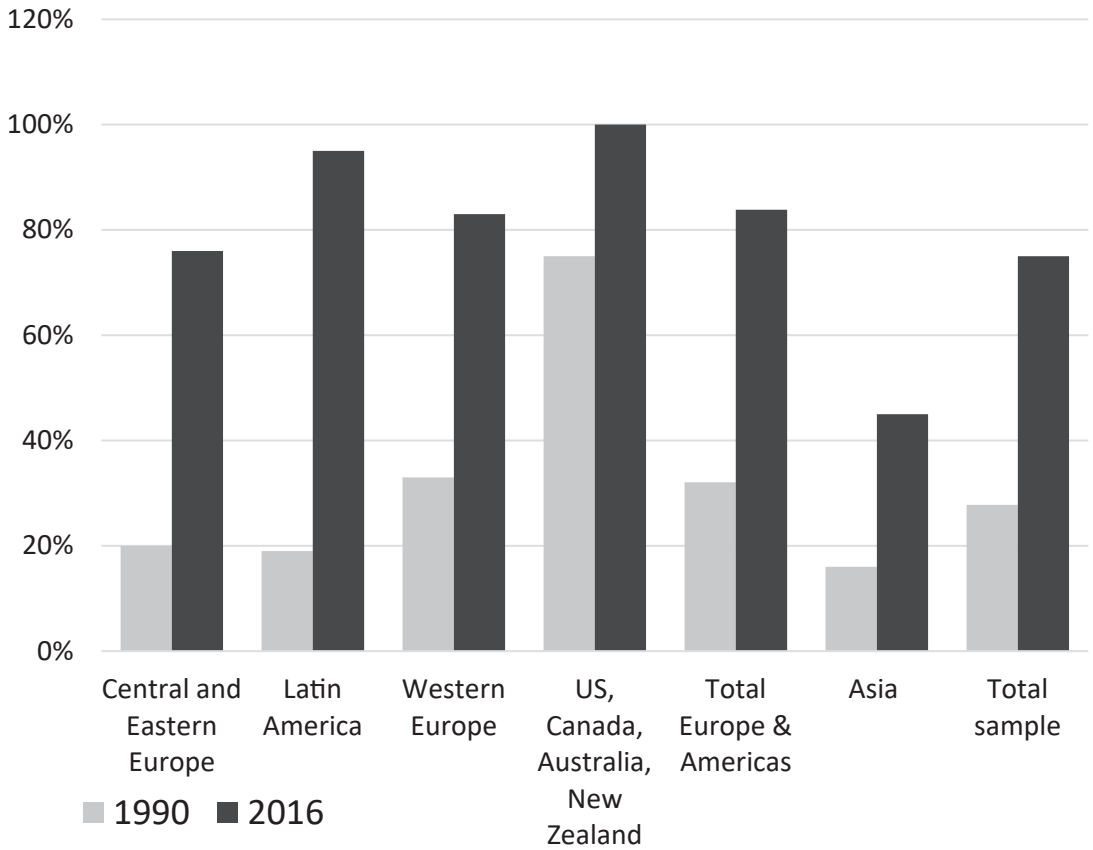

Source: reproduced from Harpaz 2019a.

Notes: The bars show the percentage of countries in each world region that permitted dual citizenship in 1990 (lighter bar) and 2016 (darker bar). The sample includes 72 countries in 1990 and 88 in 2016. ${ }^{1}$ Countries were coded as permitting dual citizenship if they formally allowed foreigners to naturalise while retaining their original citizenship or allowed their citizens to naturalise elsewhere without denationalising them. Western Europe includes the EU15 countries as well as Switzerland, Norway and Iceland (18 countries). The Latin American group includes South and Central American countries as well as the Dominican Republic, Cuba and Haiti (21 countries). Central and Eastern European countries include the post-communist members of the EU as well as Russia, Belarus, Moldova, Ukraine, Georgia, Azerbaijan, Armenia, Turkey and Malta (10 countries in 1990, 25 in 2016). Asian countries include Bangladesh, Bhutan, Cambodia, China, East Timor (which did not exist in 1990), India, Indonesia, Japan, Laos, Malaysia, Myanmar, Nepal, Pakistan, the Philippines, Singapore, South Korea, Sri Lanka, Taiwan, Thailand, Vietnam (see Harpaz 2019a).

citizenship in 1990 (among them France, the UK, Ireland and Portugal); about 50 per cent of countries in Western Europe shifted their policy in a permissive direction between 1990 and 2016.

In Latin America and Central and Eastern Europe, levels of dual citizenship acceptance in 1990 were very low, at under 20 per cent of countries. These middle-income regions 
experienced a rapid permissive shift (Escobar 2007; Liebich 2009). Today, dual-citizenship policies increasingly converge across Europe and the Americas: the acceptance of dual nationality is becoming a new norm there, where over four-fifths of countries permit dual citizenship (cf. Weil 2011). Asia also shows a trend towards the greater acceptance of dual citizenship, albeit at a slower pace. While most Asian countries - including China, India and Japan - do not permit dual citizenship, the number of countries that tolerate it has tripled since 1990.

The normalisation of dual citizenship represents a shift away from the traditional expectation that citizens maintain exclusive loyalty to their nations. This can be described as a post-exclusive turn in citizenship. It is inseparable from another transformation: a post-territorial turn in citizenship, as many countries expand the scope of the rights that they offer to their citizens abroad, including absentee voting and consular protection (Ellis et al. 2007; Gamlen 2019; Lafleur 2011). These two shifts are closely connected: the vast majority of dual citizens reside in just one country and their second citizenship comes from a country in which they do not reside. In other words, the proliferation of dual citizenship is inseparable from the spread of non-resident citizenship. The decoupling of membership and rights from physical presence significantly broadens the scope of strategies that are available to states and individuals alike (Harpaz and Mateos 2019).

\section{State strategies of dual citizenship}

To some extent, the post-exclusive shift in citizenship can be explained by pointing to global, systemic changes. Key factors include the thinning out of security considerations in citizenship policy following the end of the Cold War and growing norms of gender equality which allow women to transmit citizenship to their children (Sejersen 2008). The acceptance of dual citizenship is also tied to increased legal and normative individualism (Harpaz and Mateos 2019; Joppke 2019). Such systemic factors played a role in making dual citizenship "good to think" for governments and publics.

No country, however, moved to accept dual citizenship just because it was fashionable. Instead, governments use citizenship policy strategically, changing their laws to permit dual citizenship in response to concrete challenges and opportunities. Once dual citizenship is allowed, governments may come up with additional schemes that use it to their advantage. In this section, I discuss the strategic ways in which governments have used dual citizenship. In some cases, the strategy I discuss drove the acceptance of dual citizenship while, in other cases, it was adopted after dual citizenship was allowed. This distinction is not pertinent to the present analysis and I discuss these two dynamics together.

When analysing the kind of policies associated with dual citizenship, we should keep in mind Rogers Brubaker's (1992) dictum that the politics of citizenship are, in effect, the politics of nationhood. When citizenship laws become more or less flexible or more or 
less ethnic, this represents attempts by governments to redefine the boundaries of the nation. Post-exclusive and post-territorial shifts in citizenship allow governments to offer flexible, overlapping memberships to individuals living outside the country's territory. In the discussion below, I focus on the top-down perspective of the governments that adopt dual-citizenship policies and use them strategically (the supply side). In subsequent sections, I also present the perspective of the individuals who take up such citizenship (the demand side).

\subsection{Immigration}

Immigration is the most common scenario that produces dual citizenship. Immigrants and their children may become dual citizens through naturalisation and/or intergenerational transmission, on the condition that both receiving and sending countries permit dual citizenship.

Traditionally, naturalisation required the renunciation of the immigrant's original citizenship. In recent decades, growing numbers of countries have waived the renunciation requirement. In many cases - for example, Sweden in 2001 - dual citizenship was permitted in order to encourage the integration of immigrants by removing a major obstacle to naturalisation (Bernitz 2012). This is an example of dual-citizenship toleration being used to expand the demographic and legal boundaries of the nation inside its territory.

On the part of sending countries, a growing number have changed their laws to facilitate the retention and transmission of their citizenship by emigrants in the diaspora. A case in point is Mexico, which moved in 1998 to permit dual nationality and facilitate its transmission to second-generation Mexicans born abroad. The change was intended to encourage Mexican emigrants in the US to naturalise and gain full civic and political rights while, at the same time, trying to ensure that first- and second-generation emigrants maintain their ties to Mexico (FitzGerald 2005; Mateos 2019). Other sending countries encourage emigrant dual citizenship more actively; they include Morocco - which does not permit citizenship renunciation at all - and Turkey - which had prolonged struggles with Germany and Austria over the dual citizenship of Turkish emigrants who naturalised in those countries (Bauböck 2010). Dual citizenship, in such cases, is a strategy that aims for the continued inclusion of emigrants as part of the nation long after they cease to actually live in the country.

The expanding toleration of dual citizenship carries additional, less predictable consequences for the relations between states and individuals, relations which go beyond the domain of immigration. The post-exclusive, post-territorial legal environment allows countries to separate their citizenship policy from their immigration policy and devise novel ways of selecting citizens.

Countries have long had policies that offered facilitated access to immigration or citizenship to selected categories of individuals. The United States, Canada and Australia, among others, have investor visa schemes which cater to would-be immigrants who 
have the financial means and the motivation to create a business and run it (Sumption and Hooper 2014). Other countries have long used ethnic or cultural preferences in their immigration policy. Israel offers automatic citizenship to any Jew who settles in the country and, until recently, Germany had a similar policy towards ethnic Germans from Eastern Europe (Harpaz and Herzog 2018; Joppke 2005). Spain allows Latin American immigrants to naturalise after two years of residence, compared to the five years that are usually required (Rubio-Marin et al. 2015).

These kinds of preference - economic, ethnic or cultural - selected individuals for immigrant admission while offering them facilitated or automatic access to citizenship. The underlying assumption was that the selected individuals would enter the country and settle there. The growth of non-exclusive and non-resident citizenship allows countries to design new policies that select foreigners with desirable traits and offer them a second citizenship, without requiring either immigration or the renunciation of the original nationality. In Sections 3.2 and 3.3, I discuss a highly significant, unanticipated consequence of dual-citizenship toleration: the increasingly common policy of allowing non-resident foreigners to acquire citizenship in a long-distance manner.

\subsection{Ancestry-based external citizenship}

Many countries invite former citizens and their descendants to reacquire citizenship. In 12 European countries, emigrants who had to give up their citizenship when naturalising in another country may reclaim it without giving up their other nationality (Dumbrava 2014). In some of these countries - including Spain, Romania, Hungary, Italy, Ireland and Greece - the offer of dual citizenship extends to the children, grandchildren and sometimes even great-grandchildren of former citizens. The descendants of European emigrants living in the US, Australia, Israel or Latin America may apply to reacquire citizenship without having to move back or to give up their current citizenship. From a legalistic point of view, such policies may be seen as no more than a retroactive application of the acceptance of dual citizenship. Upon closer examination, however, there are more complex logics at work.

One key motive behind ancestry-based dual citizenship policies is governments' wish to symbolically bolster the national population in terms of size and ethno-religious composition. In most European countries, the rate of natural population growth (births minus deaths) is negative and has been so for many years. Western European countries maintain a positive population balance thanks to immigration. Meanwhile, in most Central and Eastern European countries, the population is shrinking. Against this background, moves to increase the number of citizens are perceived in a positive light by politicians and parts of the public. This view applies even if the vast majority of these new citizens will never go to live in their old-new homeland (Cook-Martín 2013; Dumbrava 2015, 2019; Fintonelli, La Barbera and Echeverría 2017). Furthermore, potential external citizens - for example, Italian or Spanish descendants in Latin America - are similar to the 
national majority in terms of their ethnicity and religion. For some, this makes them more attractive candidates for inclusion than many non-European, non-Christian immigrants who actually live in the country.

In some cases, governments set up ancestry-based dual citizenship programmes expecting electoral gains from their new citizens. Given that citizens living abroad are now allowed to vote in most national elections (Ellis et al. 2007), creating external citizens usually means creating new voters. Proposals to promote external citizenship are often supported by parties that expect to gain from the diaspora vote and opposed by those who expect little support from it (Rubio-Marin et al. 2015; Tintori 2011). Other motives that drive governments to promote ancestry-based citizenship include a wish to maintain good ties with rich and influential diasporas and hopes to attract investment. Diaspora and emigrant organisations often lobby for dual citizenship. They tend to have an impact in developing countries, in particular, where remittances are an important source of income (Escobar 2007).

\subsection{Ethnicity-based external citizenship}

Numerous countries offer external dual citizenship on the basis of ethnicity. Here, too, European countries take the lead (Dumbrava 2014; Pogonyi 2017). Co-ethnic policies use language, religion or self-identification as criteria for citizenship and these supplement or substitute for the ancestry requirement. For example, Hungary offers external dual citizenship to foreigners who can (1) prove their descent from Hungarian nationals and (2) show mastery of the Hungarian language. The language criterion aims at including cross-border ethnic Hungarians whose ancestors were stranded outside Hungary after World War One while, at the same time, excluding ethnic Romanians, Ukrainians, Serbs and Slovaks living in the same areas (Harpaz 2019a). Bulgaria gave out dual citizenship to those citizens of Macedonia, Ukraine and Moldova who declared that they identified as Bulgarian, without requiring any documented proof of descent from Bulgarian citizens (Neofotistos 2009; Smilov and Jileva 2013). Other countries with co-ethnic citizenship policies include Romania, Croatia, Serbia and Greece (Dumbrava 2014).

One of the key motivations that drive governments to adopt co-ethnic externalcitizenship policies involves making a symbolic declaration about the state's identity. The inclusion of external co-ethnics sends a powerful signal about the primacy of an ethnic over a civic definition of the nation. It demonstrates that the state "belongs" to a community of descent, traditions and identity rather than to a community of formal citizens (cf. Hayden 1992; Liebich 2009). This symbolic function can be compared to Israel's Law of Return from 1950, which institutionalises the state's Jewish character. There is a key difference, however. Israel's Law of Return, which dates back to the era of exclusive and territorial citizenship, invites diaspora Jews to come to Israel as immigrants, with citizenship as part of the package. This configuration maintains the distinction between Israelis and diaspora Jews. The latter may easily become Israeli but they are not already 
Israeli. In contrast, new co-ethnic dual-citizenship laws in Central and Eastern Europe offer citizenship outright, without conditioning it on any other tie to the state or territory. Ethnicity is directly translated into citizenship status, in what was aptly described as "post-territorial nationalism" (Ragazzi and Balalovska 2011).

Another, closely related, aim behind co-ethnic citizenship laws is to make a symbolic claim on territories in neighbouring countries. The granting of Hungarian passports to ethnic Hungarians in Transylvania (part of Romania) or Vojvodina (in Serbia) makes the point that these regions are tied to Hungary (Harpaz 2019a; Pogonyi 2017). This policy strives to negate Hungary's territorial losses from the past century - though only on a symbolic level and not by actually redrawing borders (for now). Similar motives can be identified in Romania in relation to Moldova, in Bulgaria vis-à-vis Macedonia and in Serbia and Croatia vis-à-vis parts of Bosnia-Herzegovina (Dumbrava 2019; lordachi 2004; Smilov and Jileva 2013). Given the region's long history of conflicts over territory and ethnic dominance, post-territorial nationalism appears to be a provocative strategy.

Since the end of the Balkan wars of the 1990s, however, none of these countries actually weaponised co-ethnic dual citizenship to try and take over neighbouring territories. ${ }^{2}$ There is one recent example of a country weaponising external dual citizenship for territorial expansion: Russia's use of dual citizenship to justify its 2008 invasion of Georgia. In the years leading up to the war, Russia handed out passports to Russian-speakers in the breakaway regions of Abkhazia and South Ossetia. When conflict between separatists and the Georgian government escalated, Russia launched a military invasion to "protect its citizens" (Allison 2008; Zevelev 2008). Russia also maintains a military presence in Transnistria, a breakaway region in Eastern Moldova where most of the population holds Russian dual citizenship and has been handing out passports to residents of Ukraine.

Other motives behind co-ethnic external citizenship programmes are comparable to those found in ancestry-based external citizenship, above all in terms of votes. When governments offer external citizenship, they often expect electoral support in exchange. This was especially clear in Hungary, where newly created dual citizens voted en masse for Prime Minister Orbán and helped him to win an important 2014 election campaign (Harpaz 2019a; Pogonyi 2017).

\subsection{Citizenship by investment}

The roots of present-day investment citizenship policies are traceable to the immigrant investor visa programmes of countries like the US, Canada, Australia and the UK (Sump-

2 Serbia and Croatia had different citizenship strategies during the war in Bosnia-Herzegovina. Croatia gave out co-ethnic citizenship to facilitate potential annexation of the republic's western parts. Serbia fought to keep Bosnia-Herzegovina - or at least its Serbian-populated parts - as part of a Serbian-dominated Yugoslavia. Eventually, neither country won any territory but both ended up giving out passports (Croatia in the 1990s, Serbia in the past decade). 
tion and Hooper 2014; Surak 2020). Those programmes offer immigrant visas to wealthy investors in exchange for investments that would create jobs and taxable income. Such visas can lead to citizenship relatively easily, conditional on the usual naturalisation requirements. In contrast, citizenship-by-investment programmes represent an adaptation of jus pecuniae (the right of money, see Džankić 2019) to the era of non-exclusive and non-territorial citizenship. Investors provide a sum of money and receive a passport, without having to fulfill any meaningful residence requirement or give up other allegiances.

Several small Caribbean island nations, like St Kitts and Nevis, have been offering "citizenship for sale" schemes since the 1980s (Surak 2020). After the 2008 economic crisis, similar schemes were adopted by many other nations, including EU members Malta and Cyprus, where citizenship is available to non-resident foreigners for a hefty sum of over 1 million euros (Arlidge 2019; Surak 2020). The motives are quite straightforward: exchanging passports (or residence visas) for investment appears to be an easy and attractive way to fill the state's coffers and stimulate economic activity. The wealthy individuals who acquire such citizenship very rarely establish any actual ties to the country of citizenship, lending credence to critics' claims that this is, in fact, an exchange of cash for passports (Shachar 2017; Shachar and Bauböck 2014).

\section{Citizenship and global inequality}

The growing toleration of dual citizenship allows governments to fashion flexible citizenship policies - that include non-resident foreigners - from which they expect to derive some value, which may be symbolic, demographic, electoral or economic. This is the supply side. What explains the demand side? Namely, what draws people to become citizens of a country in which they do not live and with which they often do not feel any identification?

Answering this question requires taking a broader, global view of citizenship. Typically, citizenship is analysed within the scope of a specific country. It determines who belongs to the nation and what rights they may claim (Marshall 1950). ${ }^{3}$ At the same time, citizenship operates as a legal boundary that is drawn around a country's population. Because every human is (ideally) a citizen of some state, citizenship is also a global sorting mechanism that allocates individuals to states (Brubaker 1992; Hindess 1998). This is its Westphalian function, in Rainer Bauböck's (2019) term. Given the vast disparities in citizenship value between different countries, the closure function of citizenship is a mechanism of global stratification (Shachar 2009). The hierarchy of citizenships institutionalises access to unequal packages of economic opportunities, security, rights, welfare and travel freedom (Harpaz 2019a, b).

3 The word citizenship carries additional meanings - above all, as identity and practice (Joppke 2007) - but I will set them aside here. 
Income disparities between countries are the most salient and easy-to-measure way to conceive of global inequality. The average GDP per capita in OECD member-countries (about $\$ 40,000)$ is almost four times higher than the world average $(\$ 11,000)$ and over 25 times higher than in poor sub-Saharan and South Asian countries (about $\$ 1,500$ ), even when adjusting for purchasing power parity (PPP). ${ }^{4}$ Branko Milanović (2016) calculated that income inequality between countries (i.e. location or citizenship) plays a bigger role in explaining income gaps between individuals worldwide than income inequality within a country (i.e. class). A person's citizenship is the most important factor that predicts his or her income, more than class, race or gender. Global inequality extends beyond income gaps; in fact, it applies to almost any conceivable domain of human flourishing, including security, political rights, access to health and social services and even clean air and water. For example, a child born in Sierra Leone is 60 times more likely to die before the age of five than a child in Norway (UNDP 2013). Differences in crime rates make a person living in Honduras 56 times more likely to be a victim of homicide than a resident of Canada (UNODC 2014).

Citizenship also stratifies the world's population in terms of access to other national territories beside one's own country. The world's passports are not equal. Whereas citizens of rich Western countries may travel freely throughout most of the world, travellers from less affluent and secure countries must expend substantial amounts of time and money on obtaining visas before they may travel abroad (Harpaz 2019b; see also Hobolth 2014; Mau et al. 2015; Shamir 2005).

Visa policies are a kind of "peer review" that states make of one another. They are based on an assessment of risks on the part of legislators, officials and bureaucrats in the destination country. This assessment concerns the likelihood that a citizen of a certain country (say, Uganda or Finland) will turn out to be an illegal immigrant, a criminal, a terrorist or a smuggler. Passengers from countries with high citizenship value (such as Finland) are perceived as low-risk, and enjoy visa-free access to most countries; citizens of countries with low citizenship value (such as Uganda) are seen as high-risk and their movement is controlled by strict visa requirements. The degree of travel freedom provided by the different nationalities delimits the practical opportunities open to a country's citizens while at the same time determining their place within global hierarchies of status and prestige (Harpaz 2019a).

In recent years, scholars have developed models of global inequality in citizenship value. These models compare nationalities rather than countries and calculate their relative value on the basis of the rights, entitlements and access that they provide, both within a state's territory and outside it. I present here, in brief, the model that I developed

4 Statistics from the World Bank website, "GDP per capita, current \$US". https://data.worldbank. org. When taking into account purchasing power parity (PPP), the gaps are smaller (2.7:1 and 12:1, respectively). 
(Harpaz 2019a, b) as well as a model developed by Chris Kälin and Dimitry Kochenov (Kochenov and Lindeboom 2020).

My model (Harpaz 2019a, b) integrates separate measures for the territorial and extraterritorial values of citizenship. The internal, territorial value - i.e. the worth of citizenship for a person living in the country - is calculated on the basis of three dimensions: economic development, security and democracy. In addition, I calculated the external value of citizenship as manifested by the degree of travel freedom, which I measured using the Henley and Partners Visa Restrictions Index, which ranks nationalities by the number of visa-free territories they may access (see Harpaz 2019a for details).

The analysis showed that the different components of citizenship value - development, security, democracy and travel freedom - are highly correlated. Richer countries tend to be more stable and democratic, with their citizens enjoying extensive travel freedom, while the opposite holds true for poorer countries. The rank correlations between the four different citizenship components were between 0.65 and 0.89 , at $\mathrm{p}<0.001$ (Harpaz 2019b, 903). ${ }^{5}$ The convergence of different components of citizenship value magnifies the gaps between different citizenships. The model suggests that the world's citizenship can be divided into a three-tier hierarchy: first-tier citizenship countries occupy the top 10-15 per cent of countries in both internal and external value; the middle tier of citizenship includes countries that are between the fiftieth and the ninetieth percentile on both internal and external measures; and the third tier of citizenship (by far the most populous) includes countries that are below the median in either of these dimensions.

Figure 5.2, reproduced from my book, Citizenship 2.0; Dual Nationality as a Global Asset (Harpaz 2019a), shows the world's countries, divided into three tiers of citizenship value. This map in Figure 5.2 highlights the correlation between citizenship tiers and world regions. The first-tier citizenship category includes the nations of Western Europe and Anglophone settler countries (often grouped under the title "the West"), in addition to Japan and South Korea; middle-tier countries are mostly concentrated in Latin America and Central and Eastern Europe and also include Israel, Taiwan, Singapore, Turkey, the UAE, Malaysia and South Africa. The third tier includes most countries in Asia and Africa, including China and India.

Another model for describing global inequality in citizenship value, the Quality of Nationality Index, was developed by Kälin and Kochenov and also aimed to capture both internal and external components of citizenship value. The Kälin and Kochenov model also includes a measure of settlement freedom, which indicates the right to reside and work

5 Correlations were calculated using Spearman's rank correlation coefficients, which assess the correlation between two sets of ranked variables, from 0 (no correlation) to 1 (identical ranking) (Harpaz 2019b). 
in different countries (Kochenov and Lindeboom 2017). ${ }^{6}$ Overall, the Kälin and Kochenov model produces results that are similar to those that emerge from the model described previously. Of the five citizenship ranks that it defines, the two highest categories are dominated by Western European countries and European offshoots like the United States and Australia, the middle category includes Latin American and Eastern European nations and the bottom two categories mostly consist of countries in Asia and Africa.

\section{Figure 5.2. World map divided into citizenship tiers}

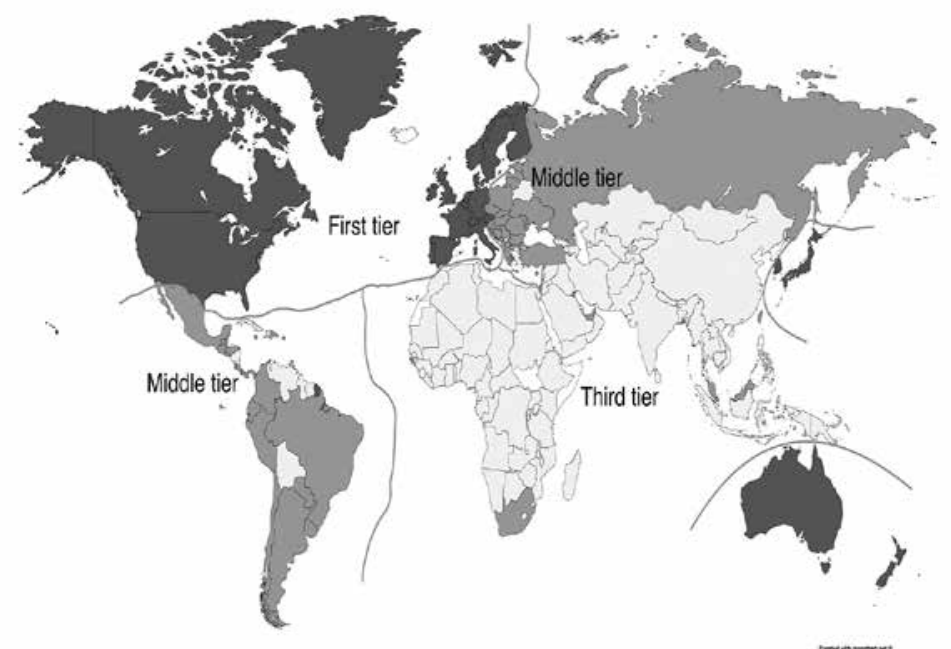

Source: reproduced from Harpaz (2019a).

Note: the map shows the world's countries according to their tier position. These reflect the aggregated territorial and extraterritorial value of citizenships. The dark-coloured countries are first tier and the light-coloured ones are third tier. Middle-tier countries are coloured in medium grey. No data were available for Somalia, South Sudan, Western Sahara, North Korea and Iceland.

To conclude this section, citizenship is a system of global stratification that allocates individuals to ranked positions. The hierarchy of travel freedom is of particular interest because it involves countries assessing one another's citizenship value. Moreover, its effects are felt even when a person ventures outside his or her country of citizenship. In the next section, I bring these insights to bear on the question of demand for dual citizenship.

6 Source: https://www.nationalityindex.com. Settlement freedom measures the extent to which citizenship of one country allows rights of work and residence in other countries, as with citizenship of EU-member countries or of other similar organisations such as Mercosur. My model does not include settlement freedom as an element of citizenship value because it does not reflect the inherent value of a country's citizenship and is subject to fluctuations. Another difference is that the Quality of Nationality Index model does not include a measure of democracy (Kochenov and Lindeboom 2020). 


\section{Understanding demand: comparative statistics on dual citizenship}

Global inequality explains patterns in the acquisition and use of dual citizenship. In this section, I support this argument on the basis of comparative statistics on dual citizenship, with a special emphasis on the long-distance acquisition of ancestry- or ethnicity-based dual citizenship.

To this end, I reproduce a dataset that uses citizenship statistics from 30 countries with a combined population of 948 million (Harpaz 2019a). The statistics refer to the population resident in the country's territory. They include 24 European countries and four Latin American countries, as well as Canada and Israel (statistics for some key countries, such as the US and the UK are unfortunately not available). In terms of citizenship tiers, there are nine first-tier and 21 middle-tier countries. I compiled these data from a variety of sources: national censuses, consular reports and existing academic publications. The figures below should be treated as minimum estimates because, in some countries, they only include part of the dual citizen population. ' I refer to a person's residence-country citizenship as their primary citizenship and their non-resident citizenship as their secondary citizenship.

Table 5.1 shows levels of dual citizenship in 23 countries out of the sample (countries with very small dual citizen populations are not shown). ${ }^{8}$

\section{Table 5.1. Prevalence and characteristics of dual citizenship in selected countries}

\begin{tabular}{lcccccc}
\hline $\mathbf{1}$ & $\mathbf{2}$ & $\mathbf{3}$ & $\mathbf{4}$ & $\mathbf{5}$ & $\mathbf{6}$ & $\mathbf{7}$ \\
Country & $\begin{array}{c}\text { Dual } \\
\text { citizens }\end{array}$ & $\begin{array}{c}\text { \% } \\
\text { dual } \\
\text { citi- } \\
\text { zens }\end{array}$ & $\begin{array}{c}\text { Most } \\
\text { common } \\
\text { secondary } \\
\text { citizenship }\end{array}$ & $\begin{array}{c}\text { Tier of } \\
\text { secondary } \\
\text { citizenship }\end{array}$ & $\begin{array}{c}\text { Main path- } \\
\text { way to } \\
\text { secondary } \\
\text { citizenship }\end{array}$ & $\begin{array}{c}\text { \% } \\
\text { foreign- } \\
\text { born }\end{array}$ \\
\hline First-tier citizenship countries & \multicolumn{7}{c}{} & & & \\
\hline Germany & $4,300,000$ & 5.3 & Russia & Middle & Immigration & 12.0 \\
France & $3,300,000$ & 5.0 & Algeria & Third & Immigration & 12.0 \\
Netherlands & $1,306,274$ & 7.7 & Morocco & Third & Immigration & 11.0 \\
Canada & 944,700 & 2.9 & UK & First/EU & Immigration & 21.0 \\
Spain & 863,000 & 1.8 & Ecuador & Middle & Immigration & 14.0
\end{tabular}

7 For all countries but one, the data pertained to the years between 2010 and 2016 (for France, the data were for 2008). In some countries the data capture only part of the dual-citizen population: in Switzerland, the data only include persons over 15 years of age; the figures for Israel, Brazil, Venezuela, Argentina and Moldova rely on statistics from the major countries of secondary citizenship and are therefore incomplete. See Harpaz (2019a) for more details.

8 The table leaves out seven countries in Central and Eastern Europe, where the number of dual citizens in 2011 was less than 50,000: Czechia, Slovakia, Albania, Bulgaria, Armenia, Montenegro and Lithuania (see Shachter 2015). 


\begin{tabular}{|c|c|c|c|c|c|c|}
\hline 1 & 2 & 3 & 4 & 5 & 6 & \\
\hline Country & $\begin{array}{c}\text { Dual } \\
\text { citizens }\end{array}$ & $\begin{array}{c}\% \\
\text { dual } \\
\text { citi- } \\
\text { zens }\end{array}$ & $\begin{array}{c}\text { Most } \\
\text { common } \\
\text { secondary } \\
\text { citizenship }\end{array}$ & $\begin{array}{c}\text { Tier of } \\
\text { secondary } \\
\text { citizenship }\end{array}$ & $\begin{array}{l}\text { Main path- } \\
\text { way to } \\
\text { secondary } \\
\text { citizenship }\end{array}$ & $\begin{array}{c}\% \\
\text { foreign- } \\
\text { born }\end{array}$ \\
\hline Switzerland & 688,561 & 8.6 & Italy & First/EU & Immigration & 29.0 \\
\hline Portugal & 244,745 & 2.3 & Brazil & Middle & Immigration & 8.0 \\
\hline Finland & 104,997 & 2.0 & Russia & Middle & Immigration & 5.0 \\
\hline Ireland & 104,784 & 2.3 & USA & First/EU & $\begin{array}{l}\text { Return } \\
\text { migration }\end{array}$ & 16.0 \\
\hline Total: first tier & $11,857,061$ & 4.3 & & & & 13.0 \\
\hline \multicolumn{7}{|c|}{ Middle-tier citizenship countries } \\
\hline Brazil & 880,000 & 0.4 & Portugal & First/EU & $\begin{array}{l}\text { Long-distance } \\
\text { acquisition }\end{array}$ & $<1.0$ \\
\hline Israel & 840,000 & 10.0 & USA & First/EU & Immigration & 26.0 \\
\hline $\begin{array}{l}\text { Bosnia-Herzego- } \\
\text { vina }\end{array}$ & 800,000 & 20.0 & Croatia & First/EU & $\begin{array}{l}\text { Long-distance } \\
\text { acquisition }\end{array}$ & $<1.0$ \\
\hline Argentina & 790,473 & 1.9 & Italy & First/EU & $\begin{array}{l}\text { Long-distance } \\
\text { acquisition }\end{array}$ & 5.0 \\
\hline Mexico & 778,000 & 0.6 & USA & First/EU & $\begin{array}{l}\text { Return } \\
\text { migration }\end{array}$ & $<1.0$ \\
\hline Venezuela & 587,555 & 2.0 & Colombia & Third & Immigration & 4.0 \\
\hline Romania & 441,331 & 2.0 & Hungary & First/EU & $\begin{array}{l}\text { Long-distance } \\
\text { acquisition }\end{array}$ & $<1.0$ \\
\hline Serbia & 401,548 & 5.5 & Hungary & First/EU & $\begin{array}{l}\text { Long-distance } \\
\text { acquisition }\end{array}$ & 6.0 \\
\hline Poland & 327,500 & 1.0 & Germany & First/EU & $\begin{array}{l}\text { Long-distance } \\
\text { acquisition }\end{array}$ & 2.0 \\
\hline Moldova & 326,000 & 9.0 & Romania & First/EU & $\begin{array}{l}\text { Long-distance } \\
\text { acquisition }\end{array}$ & 11.0 \\
\hline Greece & 190,000 & 1.7 & Albania & Middle & Immigration & 9.0 \\
\hline Hungary & 88,906 & 0.9 & Romania & First/EU & Immigration & 5.0 \\
\hline Croatia & 86,404 & 2.0 & Bosnia & Middle & Immigration & 18.0 \\
\hline Russia & 78,615 & 0.1 & Ukraine & Middle & Immigration & 8.0 \\
\hline Total: middle tier & $6,723,374$ & 1.0 & & & & 3.5 \\
\hline Total sample & $18,580,435$ & 2.0 & & & & 6.0 \\
\hline
\end{tabular}

Source: Harpaz 2019a.

Note: Columns 2 and 3 present the number of dual citizens in each country in absolute numbers and as a percentage of the total population. Column 4 presents the leading country of secondary citizenship and Column 5 its citizenship tier. Column 6 presents the pathway that characterises the leading country of secondary citizenship. Column 7 presents the percentage of foreign-born immigrants in the country's population. The totals also include low-prevalence countries (fewer than 50,000 dual citizens) that are not shown in the table. 
The table compares levels of dual citizenship in various countries, highlighting differences that have to do with global citizenship stratification. Column 2 presents the number of dual citizens in each country. While absolute numbers of dual citizens in first-tier countries are significantly higher, numerous middle-tier countries host substantial populations of dual citizens. In this sample, average levels of dual citizenship as a percentage of the population (Column 3) are much higher in first-tier countries - 4.3 per cent compared to 1 per cent in middle-tier countries. Nonetheless, the three countries with the highest percentage of dual citizens were middle tier: Bosnia-Herzegovina, Israel and Moldova. Overall, almost a third of dual citizens in the sample were in middle-tier countries.

Columns 4 and 5 list the most common country of secondary citizenship and its tier position for each residence country. In first-tier countries, secondary citizenship tiers were mixed. The countries with the highest numbers of dual citizens - Germany, France and the Netherlands - were dominated by middle-tier or third-tier citizenship countries (for example, Algerian dual citizenship in France). This represents the expected pattern of immigration and citizenship: people move from less-developed to more-developed countries and - when given the option - retain their original citizenship when they naturalise.

Moving on to middle-tier countries, however, we find less-expected patterns of dual citizenship: the leading country of secondary citizenship was typically an EU country or the United States. In all but one of the ten middle-tier countries with the highest numbers of dual citizens, the dominant secondary citizenship was from a Western or EU country. Middle-tier countries where the dominant secondary citizenship was from a middle- or third-tier country (like Greece or Croatia) typically had very low numbers of dual citizens. Thus, secondary citizenship in middle-tier countries was typically from a Western or EU country.

Columns 6 and 7 list the pathways to dual citizenship in countries of different citizenship tiers. Western European and North American countries receive large numbers of immigrants. Dual citizenship there is created in the context of immigration and is mainly found among first- and second-generation immigrants. The leading countries of secondary citizenship in first-tier countries were typically those that have sent the largest numbers of immigrants - for example, Algeria in France and Morocco in the Netherlands. ${ }^{9}$

Most middle-tier countries, in contrast, receive little immigration. Except in Israel and Venezuela, ongoing immigration is not the main process that produces dual citizenship. ${ }^{10}$ Instead, dual citizens in middle-tier countries mainly consist of native-born citizens who have acquired secondary citizenship in a long-distance manner from a

9 Source: United Nations migration statistics.

10 Hundreds of thousands of Colombian immigrants naturalised in Colombia in the 2000s. The long-distance acquisition of EU citizenship was an additional major pathway to dual citizenship in Israel and Venezuela, as well as in Mexico (see Harpaz 2013, 2019a). 
European Union country on the basis of descent or ethnicity. For example, Argentinians and Brazilians acquire descent-based citizenship from Italy, Portugal and Spain. Serbians and Ukrainians, meanwhile, acquire co-ethnic citizenship from Hungary, Romania, Bulgaria and Croatia. Long-distance acquisition was the dominant pathway to dual citizenship in most of the leading middle-tier countries in the table. In Mexico, secondary citizenship from the US is produced in the context of circular migration, which includes return migration and deportation, as well as some parents' strategic decision to give birth in the United States in order to secure dual nationality for their children (Harpaz 2019a).

Statistics on the acquisition of ancestry- or ethnicity-based citizenship from EU countries reinforce this picture. Between 1998 and 2010, over one million persons have acquired Italian dual citizenship on the basis of descent. Over a million people have acquired Hungarian co-ethnic citizenship since 2011 (Harpaz 2019a). Spain and Romania, as well, gave citizenship to hundreds of thousands of non-residents (Harpaz 2015). Almost all the applicants for ancestry-based or co-ethnic citizenship came from middle-tier citizenship countries in Latin America and Eastern Europe. Almost none of the millions of eligible individuals living in Western Europe and North America have applied for this kind of dual citizenship. For example, out of 18 million Americans who have some Italian ancestry, no more than 25,000 acquired ancestry-based Italian citizenship in 1998-2010 (Harpaz 2015, 2019a).

This demonstrates that global inequality in citizenship value shapes patterns of dual citizenship acquisition. In Western countries with first-tier citizenship, dual citizenship is mostly produced as a result of immigration from lower-tier countries. In middle-tier countries outside the West, dual citizenship is typically from Western countries and it is produced deliberately through strategies of long-distance acquisition.

Qualitative work on long-distance dual citizenship corroborates these findings and helps to flesh them out (see, for example, Altan-Olcay and Balta 2020; Cook-Martín 2013; Knott 2019; Mateos 2019; Pogonyi 2017). For the sake of brevity, I will just mention three cases (Harpaz 2019a): Israelis who acquired ancestry-based EU citizenship, Serbians with co-ethnic citizenship from EU-member Hungary and Mexicans who strategically gave birth in the US to provide a second nationality for their children.

In all three cases, applicants were interested in securing a second passport that would improve their travel freedom and specifically make it easier to visit EU countries and the United States. Thanks to the boost in travel freedom, the second passport was often also seen as a status symbol (see Harpaz 2013). Another key motivation was risk management: Israelis feared a catastrophic war with their Arab neighbours, whereas Mexicans were concerned about rampant criminal violence; in both countries, having an EU or US passport was seen as an "insurance policy". Finally, the second passport was seen as a key to economic opportunities: Israelis said that EU passports would make it easier for them to study and work in EU countries if they wished to, while many Mexicans 
wanted to give their children the option to study in the United States. In Serbia, many used their Hungarian passports to seek work - either temporary or long-term - in EU member-countries Germany, Austria and Sweden.

These three uses - travel freedom, security and economic opportunities - are derived from the higher practical value of EU/US citizenship relative to applicants' primary, resident citizenship. I should stress that these instrumental motives were not the only reasons why people in these countries sought dual citizenship. Members of Serbia's Hungarian minority were excited and proud to be officially Hungarian - the feeling seemed to be even stronger among ethnic Hungarians in Romania (Pogonyi 2017), and some Israelis had a sense of historical justice when given "back" their grandparents' German, Polish or Romanian citizenship.

Nonetheless, the main motivation driving applications was instrumental. This is seen from the acquisition statistics and patterns of use that were discussed above. As an illustration of instrumental citizenship, consider this extreme case taken from the Israeli sample. In a 2015 interview, this 31-year-old, Israeli-born man told me about his quest for an EU passport. He began in the Polish embassy in Tel-Aviv, continued with attempts to dig up Czech roots, then went on to check his eligibility for Greek citizenship; he then tried the Turkish embassy before, finally, approaching the Hungarian authorities. In each case, he encountered some legal hurdle that made him ineligible for citizenship. Having exhausted the birth places of all four grandparents, he was ready to give up. At that moment, however, Spain and Portugal passed laws offering citizenship to Sephardic Jews, which include the Jewish communities of Greece and Turkey. In a follow-up interview in 2019 , he proudly announced that he had finally become a Spanish citizen. In spite of his satisfaction at gaining an EU passport, he still stood by his words in the 2015 interview: "The passport I would have really liked to have is American [...] but I'll take whatever I can get" (Harpaz 2019a, 106-107).

\section{Conclusion}

This chapter has outlined some of the political and economic forces that shape the global phenomenon of dual citizenship. I have pointed out the new strategic options that open up for states and individuals once the traditional criteria of exclusive belonging and territorial presence are waived. The emerging picture is consistent with recent arguments about citizenship becoming instrumental (Joppke 2019) or strategic (Harpaz and Mateos 2019). It also highlights the close connection between dual citizenship and the burgeoning study of diaspora politics and cross-border nationalism (Bauböck 2010; Gamlen 2019; Ragazzi and Balalovska 2011).

The dynamics of citizenship described in this chapter evolved over a period of three decades marked by increasingly open borders. Over these years of globalisation, human experience itself was becoming increasingly mobile and flexible. Under these conditions, 
the strategic approach to national membership flourished. It is not clear how this legal and normative reality will be impacted on by the Covid-19 pandemic, which put an abrupt halt to most kinds of international movement. It remains to be seen whether this crisis - and other, related, global crises that are likely to follow it - will devalue dual citizenship by restricting mobility or, on the contrary, will make it doubly important because of heightened political and economic risk.

\section{References}

Allison, R. 2008. Russia resurgent? Moscow's campaign to "coerce Georgia to peace", International Affairs, 84(6): 1145-1171.

Altan-Olcay, Ö. and Balta, E. 2020. The American Passport in Turkey: National Citizenship in the Age of Transnationalism. Philadelphia: University of Pennsylvania Press.

Arlidge, J. 2019. Investigation: citizenship for sale, The Sunday Times, 24 March. Available at: https://www.thetimes.co.uk/article/investigation-is-selling-passports-encouraging-terrorism-money-laundering-and-tax-evasion-pmbxcc6c8 (accessed 21 December 2020).

Bauböck, R. 2010. Studying citizenship constellations, Journal of Ethnic and Migration Studies, 36(5): 847-859.

Bauböck, R. 2019. Genuine links and useful passports: evaluating strategic uses of citizenship, Journal of Ethnic and Migration Studies, 45(6): 1015-1026.

Bernitz, Hedvig 2012. Country Report: Sweden. Florence: European University Institute, GLOBALCIT Country Citizenship Report.

Brubaker, R. 1992. Citizenship and Nationhood in France and Germany. Cambridge, MA: Harvard University Press.

Cook-Martín, D. 2013. The Scramble for Citizens: Dual Nationality and State Competition for Immigrants. Stanford, CA: Stanford University Press.

Dumbrava, C. 2014. Nationality, Citizenship and Ethno-Cultural Belonging. Preferential Membership Policies in Europe. Basingstoke: Palgrave Macmillan.

Dumbrava, C. 2015. Super-foreigners and sub-citizens: mapping ethno-national hierarchies of foreignness and citizenship in Europe, Ethnopolitics: Formerly Global Review of Ethnopolitics, 14(3): 296-310.

Dumbrava, C. 2019. The ethno-demographic impact of co-ethnic citizenship in Central and Eastern Europe, Journal of Ethnic and Migration Studies, 45(6): 958-974.

Džankić, J. 2019. The Global Market for Investor Citizenship. Basingstoke: Palgrave Macmillan.

Ellis, A., Navarro, C., Morales, I., Gratschew, M. and Braun, N. 2007. Voting from Abroad: The International IDEA Handbook. Federal Electoral Institute of Mexico. Retrieved from https://www.idea.int/sites/default/files/publications/voting-from-abroad-the-international-idea-handbook.pdf (accessed 21 December 2020). 
Escobar, C. 2007. Extraterritorial political rights and dual citizenship in Latin America, Latin American Research Review, 42(3): 43-75.

Finotelli, C., La Barbera, M. and Echeverría, G. 2017. Beyond instrumental citizenship: the Spanish and Italian citizenship regimes in times of crisis, Journal of Ethnic and Migration Studies, 44(14): 2320-2339.

FitzGerald, D. 2005. Nationality and migration in modern Mexico, Journal of Ethnic and Migration Studies, 31(1): 171-191.

Gamlen, A. 2019. Human Geopolitics: States, Emigrants, and the Rise of Diaspora Institutions. Oxford: Oxford University Press.

Harpaz, Y. 2013. Rooted cosmopolitans. Israelis with a European passport: history, property, identity, International Migration Review, 47(1): 166-206.

Harpaz, Y. 2015. Ancestry into opportunity: how global inequality drives demand for long-distance European Union Citizenship, Journal of Ethnic and Migration Studies, 31(13): 2081-2104.

Harpaz, Y. 2019a. Citizenship 2.0: Dual Nationality as a Global Asset. Princeton, NJ: Princeton University Press.

Harpaz, Y. 2019b. Compensatory citizenship: dual nationality as a strategy of global upward mobility, Journal of Ethnic and Migration Studies, 45(6): 897-916.

Harpaz, Y. and Herzog, B. 2018. Country Report: Israel. Florence: European University Institute, GLOBALCIT Country Citizenship Report.

Harpaz, Y. and Mateos, P. 2019. Introduction: strategic citizenship: negotiating membership in the age of dual nationality, Journal of Ethnic and Migration Studies, 45(6): 843-857.

Hayden, R. 1992. Constitutional nationalism in the formerly Yugoslav republics, Slavic Review, 51(4): 654-673.

Hindess, B. 1998. Divide and rule: the international character of modern citizenship, European Journal of Social Theory, 1(1): 57-70.

Hobolth, M. 2014. Researching mobility barriers: the European visa database, Journal of Ethnic and Migration Studies, 40(3): 424-435.

Iordachi, C. 2004. Dual citizenship in post-communist Central and Eastern Europe: regional integration and inter-ethnic tensions, in leda, O. and Tomohiko, U. (eds) Reconstruction and Interaction of Slavic Eurasia and its Neighboring World. Sapporo: Hokkaido University, Slavic Research Center, 105-139.

Joppke, C. 2005. Selecting by Origin: Ethnic Migration in the Liberal State. Cambridge, MA and London: Harvard University Press.

Joppke, C. 2007. Transformation of citizenship: status, rights, identity, Citizenship Studies, 11(1): 37-48.

Joppke, C. 2019. The instrumental turn of citizenship, Journal of Ethnic and Migration Studies, 45(6): 858-878.

Knott, E. 2019. Strategy, identity or legitimacy? Analysing engagement with dual citizenship from the bottom-up, Journal of Ethnic and Migration Studies, 45(6): 994-1014. 
Kochenov, D. and Lindeboom, J. 2017. Empirical assessment of the quality of nationalities, European Journal of Comparative Law and Governance, 4(4): 314-336.

Kochenov, D. and Lindeboom, J. (eds) 2020. Kälin and Kochenov's Quality of Nationality Index. An Objective Ranking of the Nationalities of the World. Oxford: Hart Publishing. Lafleur, J.-M. 2011. Why do states enfranchise citizens abroad? Comparative insights from Mexico, Italy and Belgium, Global Networks, 11(4): 481-501.

Liebich, A. 2009. Introduction: Altneuländer or the vicissitudes of citizenship in the new EU states, in Bauböck, R., Perching, B. and Sievers, W. (eds) Citizenship Policies in the New Europe. Amsterdam: Amsterdam University Press, 21-42.

Marshall, T.H. 1950. Citizenship and Social Class. Cambridge: Cambridge University Press. Mateos, P. 2019. The mestizo nation unbound: the dual citizenship of Euro-Mexicans and US- Mexicans, Journal of Ethnic and Migration Studies, 45(6): 917-938.

Mau, S., Gülzau, F., Laube, L. and Zaun, N. 2015. The global mobility divide: how visa policies have evolved over time, Journal of Ethnic and Migration Studies, 41 (8): 1192-1213. Milanović, B. 2016. Global Inequality: A New Approach for the Age of Globalization. Cambridge, MA: Harvard University Press.

Neofotistos, V. 2009. Bulgarian passports, Macedonian identity, Anthropology Today, 25(4): 19-22.

Pogonyi, S. 2017. Extra-Territorial Ethnic Politics, Discourses and Identities in Hungary. London: Palgrave Macmillan.

Ragazzi, F. and Balalovska, K. 2011. Diaspora Politics and Post-Territorial Citizenship in Croatia, Serbia and Macedonia. Edinburgh: School of Law, University of Edinburgh, CITSEE Working Paper.

Rubio-Marin, R., Sobrino, I., Martín Pérez, A. and Moreno Fuentes, F.J. 2015. Country Report on Citizenship Law: Spain. Florence, European University Institute, GLOBALCIT.

Sejersen, T.B. 2008. "I vow to thee my countries": the expansion of dual citizenship in the 21st century, International Migration Review, 42(3): 523-549.

Shachar, A. 2009. The Birthright Lottery: Citizenship and Global Inequality. Cambridge, MA: Harvard University Press.

Shachar, A. 2017. Citizenship for sale?, in Shachar, A., Bauböck, R., Bloemraad, I. and Vink, M. (eds) The Oxford Handbook of Citizenship. Oxford: Oxford University Press, 644-668.

Shachar, A. and Bauböck, R. 2014. Should Citizenship be for Sale? Florence: Robert Schuman Centre for Advanced Studies Research Paper 2014/01.

Shachter, J. 2015. Dual citizenship trends and their implication for the collection of migration statistics, International Journal of Statistics and Geography, 6(2): 40-51.

Shamir, R. 2005. Without borders? Notes on globalization as a mobility regime, Sociological Theory, 23(2): 197-217.

Shuck, P. 2002. Plural citizenships, in Hansen, R. and Weil, P. (eds) Dual Nationality, Social Rights and Federal Citizenship in the US and Europe. New York and Oxford: Berghahn, 61-100. 
Smilov, D. and Jileva, E. 2013. Country Report: Bulgaria. Florence: EUDO Citizenship Observatory, Robert Schuman Centre for Advanced Studies.

Spiro, P.J. 1997. Dual nationality and the meaning of citizenship, Emory Law Journal, 46(4): 491-565.

Spiro, P.J. 2015. Report on Citizenship Law: United States of America. Florence: European University Institute, GLOBALCIT Country Citizenship Report.

Sumption, M. and Hooper, K. 2014. Selling Visas and Citizenship. Washington, DC: Migration Policy Institute.

Surak, K. 2020. Millionaire mobility and the sale of citizenship, Journal of Ethnic and Migration Studies, DOI: 10.1080/1369183X.2020.1758554.

Tintori, G. 2011. The transnational political practices of 'Latin American Italians'. International Migration 49.3: 168-188.

UNDP 2013. Under-Five Mortality Rate (per 1,000 Live Births). New York: United Nations Development Programme. Available at: http://hdr.undp.org/en/content/under-fivemortality-rate-1000-live-births (accessed 21 December 2020).

UNODC 2014. Intentional Homicide Count and Rate per 100,000 Population, by Country/ Territory (2000-2012). Vienna: United Nations Office on Drugs and Crime. Available at: https://www.unodc.org/gsh/en/data.html (accessed 21 December 2020).

Vink, M., Schakel, A.H., Reichel, D., Chun Luk, N. and de Groot, G.-R. 2019. The international diffusion of expatriate dual citizenship, Migration Studies, 7(3): 362-383.

Weil, P. 2011. From conditional to secured and sovereign: the new strategic link between the citizen and the nation-state in a globalized world, International Journal of Constitutional Law, 9(3-4): 615-635.

Zevelev, I. 2008. Russia's policy toward compatriots in the Former Soviet Union, Russia in Global Affairs, 6(1): 49-62. 



\section{Dual Citizenship in Comparative Perspective}





\title{
Chapter 6
}

\section{Dual Citizenship Acceptance and Immigrant Naturalisation Propensity in the Netherlands: The Relevance of Origin- and Destination-Country Rules}

\author{
Floris Peters, Maastricht University \\ Maarten Vink, European University Institute, Florence
}

\begin{abstract}
There is ample evidence that the possibility of holding dual citizenship is a key predictor of immigrant naturalisation. Over past decades, both migrant origin and destination countries have liberalised rules with regards to dual citizenship. Nevertheless, the acceptance of dual citizenship remains contested and a few countries have gone against the global tide by (re-)introducing restrictions. In this chapter we investigate the role of dual citizenship acceptance in origin and destination countries for immigrants' propensity to naturalise in the Netherlands, in the period around the reintroduction of the renunciation requirement there in 1997. While a declining post-reform trend in the number of naturalisations has been widely observed, there is limited research on the heterogenous impact of dual citizenship acceptance. We use individual-level register data and apply a Cox proportional hazards regression to analyse the propensity to naturalise among immigrants who could naturalise with or without dual citizenship. We identify dual citizenship acceptance by combining the changing regulations in the Netherlands with information on origin-country citizenship rules around the world. We find that the propensity to naturalise is higher among those who can hold dual citizenship and remains so almost two decades after migration to the host country. We show that dual citizenship acceptance especially affects naturalisation rates among immigrants from EU and other highly developed countries.
\end{abstract}

\section{Introduction}

In a political agreement at the start of a new government period in 2017, the current governing coalition of the Netherlands stated its intention to "modernise Dutch citizenship law" by liberalising the opportunities for dual citizenship of future foreign-born immigrants and emigrants (Rijksoverheid 2017,6). At present, Dutch citizenship law stipulates that a foreigner who acquires Dutch citizenship through naturalisation but does not automatically lose her or his original citizenship in the process is - barring exceptions - in principle required to renounce her or his other citizenship(s). This requirement is increasingly uncommon in the European Union (EU), where most countries have followed 
the global trend of accepting dual citizenship (Vink et al. 2019, 370). In this context, critics of the renunciation requirement in the Netherlands argue that naturalisation is an important step in the integration process of immigrants and that the possibility to retain the original citizenship upon naturalisation facilitates political integration by removing an important obstacle to citizenship acquisition. ${ }^{2}$

The literature on the propensity of immigrants to naturalise is relatively conclusive about the impact of dual citizenship toleration. Several studies show that citizenship acquisition is more likely if migrants are able to retain their original citizenship upon naturalisation (Jones-Correa 2001; Labussière and Vink 2020; Mazzolari 2009; Peters, Vink and Schmeets 2016; but see Helgertz and Bevelander 2017). This is generally explained through the notion of a cost-benefit calculation, the central paradigm in this field of literature since the 1990s (Yang 1994). From this perspective, renouncing the original citizenship - and the rights attached to it - constitutes a considerable cost to naturalisation. Yet what is less clear is to whom dual citizenship matters the most or how the opportunity to hold dual citizenship affects the speed at which the host-country citizenship is acquired. Drawing on life-course concepts and principles (Peters and Vink 2016), citizenship acquisition can be understood in a biographical sense, whereby the utility of citizenship is conditioned by migrants' individual, social and institutional circumstances. From that perspective, we argue that not being able to hold dual citizenship primarily constitutes an obstacle to naturalisation for those whose original passport is relatively valuable - such as migrants from the EU or from other highly developed countries (Bevelander et al. 2015; Vink et al. 2021). Moreover, we expect the relevance of the opportunity to hold dual citizenship to gradually diminish as migrants settle and build their lives in the host country.

In this chapter we focus on naturalisation propensity around a dual citizenship restriction that was reintroduced in the Netherlands in 1997. In November 1991, the Dutch government decided that it no longer required foreigners to renounce their other citizenships upon naturalisation. This unofficial toleration period came to an end in June 1997, when the requirement was reintroduced. Yet besides the destination-country context we also take into account the origin context and identify dual citizenship acceptance by combining the changing regulation in the Netherlands in 1997 with information on origin-country citizenship rules around the world. We do so because being able to naturalise while retaining the origin-country citizenship depends both on the legislation of the origin country - in terms of whether or not the citizenship is automatically lost

1 The following 11 countries still have a renunciation requirement in the EU: Austria, Bulgaria, Croatia, the Czech Republic, Estonia, Germany, Latvia, Lithuania, the Netherlands, Slovenia and Spain.

2 See, for instance, Kamerstuk 16947 (R1181), no. 27 and Kamerstuk 21 427, no. 3 (reprint), pp. 30-31. 
upon voluntary renunciation and, if it is not, whether an individual is able to renounce this voluntarily - as well as on the changing citizenship policy in the Netherlands, which did not require migrants to renounce their citizenship of origin during the early 1990s - if they could - but did so from 1997 onwards. Hence, we identify dual citizenship acceptance dynamically - based on a combination of destination and origin regulations - and analyse the impact on the naturalisation propensity among immigrants. We use individual-level register data and apply a Cox proportional hazards regression to analyse the propensity to naturalise among immigrants who could do so with or without dual citizenship. Subsequently we explore impact heterogeneity for different groups based on the established cost-benefit framework in the literature and analyse the extent to which the opportunity to hold dual citizenship continues to matter as time in the host country passes.

The chapter starts with a brief outline of the history of the renunciation requirement in the Netherlands surrounding the Dutch toleration period. This is followed by a discussion of the data and research design and the results of the analysis. The paper concludes with a summary of the main findings and a reflection on their implications for the literature, as well as for policy-makers.

\section{Institutional context}

Dual citizenship has been controversial in the Netherlands over the past three decades and continues to be contested today. The traditional approach to dual citizenship in the Netherlands is a restrictive one, as reflected in the signature and ratification of the 1963 Strasbourg Convention on the Reduction of Cases of Multiple Nationality and in the Dutch Nationality Act (DNA) that has been in place since 1 January 1985 - see Van Oers, de Hart and Groenendijk (2013) for an overview of historical developments and current citizenship law in the Netherlands. In the Netherlands, on the one hand, a foreign national who acquires Dutch citizenship by option declaration (DNA, art. $6 \mathrm{a}(1))^{3}$ or naturalisation (DNA, art. 9(1)(b)) in principle is expected to renounce her or his other citizenship(s), unless she or he already automatically loses that citizenship or cannot reasonably be expected to do so; similarly, a Dutch citizen who voluntarily acquires another citizenship automatically loses Dutch citizenship, unless one of the exceptions indicated by the law applies (DNA, art. 15(1)(a)).

This restrictive approach in Dutch citizenship law is in line with an overall sceptical attitude towards dual citizenship among the electorate, although voters in the Netherlands appear more reluctant to accept dual citizenship among naturalising immigrants

3 The option declaration is a faster and less costly procedure, with fewer conditions, through which an individual can acquire Dutch citizenship by making a statement expressing that he or she "opts" for Dutch citizenship. 
than among Dutch citizens naturalising abroad (Vink, Schmeets and Mennes 2019; cf. de Hart 2007, 92). At the same time, since the 1980s, immigrant groups and parties on the (centre-)left of the political spectrum in the Netherlands have pressured subsequent governments to liberalise their legal attitude towards dual citizenship. Two arguments were of crucial importance: equality and representation.

First, the single most important feature of the 1985 amendment of the DNA was the equal treatment of men and women. Whereas previously there were important gender-based restrictions, since 1985 Dutch women can independently transmit Dutch citizenship to their child, even if the husband of the women is a foreigner and the child will also acquire a foreign citizenship through him. As a result, dual citizenship became increasingly prevalent in the Netherlands; if this is allowed for children of mixed-citizenship parentage, then why still restrict this for naturalising immigrants?

Second, immigrant groups and their advocates have argued that dual citizenship restriction presents an obstacle to immigrant integration, given that the renunciation requirement constitutes an important deterrent to immigrant naturalisation (van den Bedem 1993, 31-35). While political rights were, to some extent, decoupled from citizenship in 1986 by granting resident non-citizens local voting rights, at the national level voting rights remained (and remain) tied to citizenship. Low naturalisation rates thus resulted in a significant representation gap in the Netherlands. When, at the end of the 1980s, the centre-right government at the time asked the Scientific Council for Government Policy to advice on immigrant integration policy, the Council advised liberalising dual-citizenship policy and allowing migrants to retain their original citizenship upon naturalisation in order to strengthen the legal standing of immigrants and improve opportunities for participation and integration (WRR 1989, 93-96; cf. Heijs 1995, 198-203).

The new centre-left coalition that took office in 1989 subsequently emphasised in its governing programme that immigrants in the Netherlands should be able to acquire Dutch citizenship "without much ado"4 and, in November 1991, after considerable parliamentary debate, the government decided to no longer require naturalising foreigners to renounce their other citizenship. The new policy, reflected in a ministerial recommendation (circulaire), ${ }_{1}^{5}$ only applied to immigrants; Dutch citizens continued to automatically lose their citizenship upon naturalisation abroad (Van Oers, de Hart and Groenendijk 2013, 16).

A proposal to formally amend the DNA and abolish the renunciation requirement was subsequently introduced in February $1993 .{ }^{6}$ However, the bill encountered increasing political resistance due to the fragile political basis of the original compromise and changing political coalitions. The main opposition, from the right and centre-right,

\footnotetext{
4 Kamerstuk 21 132, nr. 8, vergaderjaar 1989-1990, p. 43.

5 Staatscourant 1992, no. 25.

6 Wetsvoorstel 23029 (R1461).
} 
focused on the idea that the possession of multiple citizenships would result in ambiguous loyalties and undermine the socio-cultural integration of groups already at risk of segregation within society. ${ }^{7}$ The bill's progress through parliament was stalled by these disagreements and, crucially, failed to be approved by the Senate in November 1996, resulting in its withdrawal. Subsequently the renunciation requirement was reinstated in June 1997, again by means of a ministerial recommendation, including a new provision that foreigners who were married to a Dutch citizen were not required to renounce their other citizenship. ${ }^{8}$ As before, persons benefiting from international protection, those who automatically lose their citizenship due to the nationality legislation of the country of the other citizenship, as well as those who are not able or cannot reasonably be expected to renounce their other citizenship were also exempt. These exemptions remained in place when a major revision of the DNA was introduced in 2003 and continue to be applicable today. ${ }^{9}$ Based on statistics covering the period 2007-2011, around two-thirds of persons (66 per cent) who acquire Dutch citizenship via naturalisation or option declaration are estimated to be able to hold dual citizenship (Ministerie van Veiligheid en Justitie 2012). ${ }^{10}$

Figure 6.1 displays the aggregate citizenship acquisition rate in the Netherlands through naturalisation or option over the past three decades. This suggests a substantial impact of the temporary liberalisation and subsequent restriction of dual citizenship, as has been frequently observed by others (de Hart 2007, 15-16; Entzinger 2006, 126-127; van Oers, de Hart and Groenendijk 2013, 17-18). The number of naturalisations increased sharply during the 1990 s to over 80,000 in 1996 , subsequently decreasing again in several waves, only to stabilise at around 30,000 per year by about 2003. However, since the Netherlands in the 1990s also observed a strong increase in the number of asylum-seekers, who are generally associated with high naturalisation rates (van Oers, de Hart and Groenendijk 2013, 18), micro-level analysis is required to estimate the magnitude and heterogeneity of the effect of dual-citizenship policy.

7 Kamerstuk 23029 (R1461), no. 26a, pp. 1-2.

8 Staatscourant 1997, no. 128. This exception reflected the Second Protocol to the 1963 Strasbourg Convention, which was adopted in 1993 and had been signed by the Netherlands and ratified in 1996.

9 See here for a complete outline of applicable rules with regards to the renunciation requirement, including a list of applicable rules by country: https://ind.nl/en/Pages/Renouncing-your-current-nationality.aspx.

10 This estimate is based on the observation that around 34 per cent of persons acquiring Dutch citizenship cannot hold dual citizenship, either because they automatically lose their citizenship due to home-country regulations upon acquiring Dutch citizenship (18 per cent) or because a renunciation procedure was started in the Netherlands (16 per cent). Note that some persons may have been exempt from the renunciation requirement at a later stage if renunciation turned out to be impossible or to have detrimental economic consequences in the origin country). 


\section{Figure 6.1. Number of persons acquiring Dutch citizenship by naturalisation or through option declaration, 1990-2018}

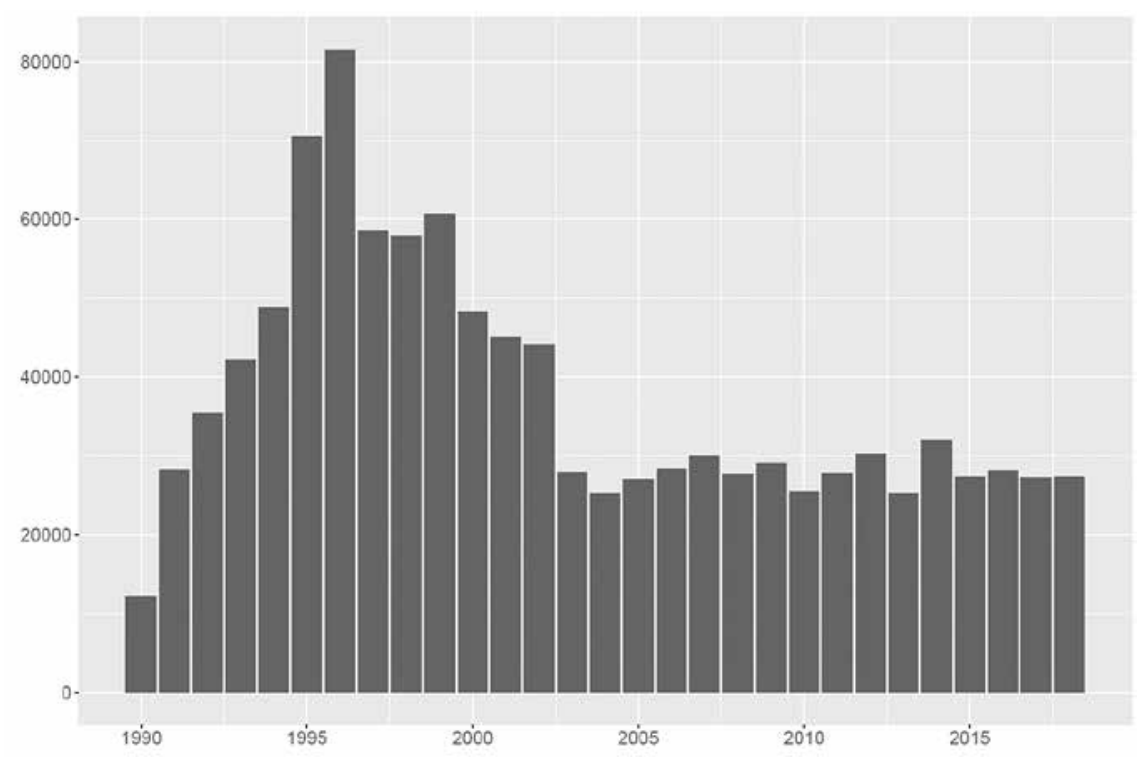

\section{Research design}

\subsection{Data and sample}

To study the impact of dual citizenship on immigrant naturalisation, this paper draws on administrative data from the System of Social Statistical Datasets. Developed by Statistics Netherlands, this database provides linked micro-level information from a variety of sources, including municipalities, the tax authorities and the Immigration and Naturalisation Service. The data include all legally registered individuals in the Netherlands - for more information, see Bakker, van Rooijen and van Toor (2014). These individual-level register data are linked to country-level information on expatriate dual citizenship policy from the MACIMIDE Global Expatriate Dual Citizenship Dataset (Vink, de Groot and Luk 2015). This dataset charts the rules of nearly all countries in the world since 1960 with regards to the loss or renunciation of citizenship after a citizen voluntarily acquires that of another state. Figure 6.2 provides an overview of the various origin-country policies that the migrants in our Dutch sample (see below) are subject to.

The research population consists of all foreign-born individuals who migrated to the Netherlands between 1985 and 1997. We track these individuals from 1995 to 2003, with yearly observations on the first of January of each year (observations $=865,224$; $\mathrm{N}=294,685$ ). Migrants in the sample thus fell under the DNA of 1985 before its revi- 


\section{Figure 6.2. Stepwise overview of the criteria by which the moment of eligibility} for naturalisation is determined

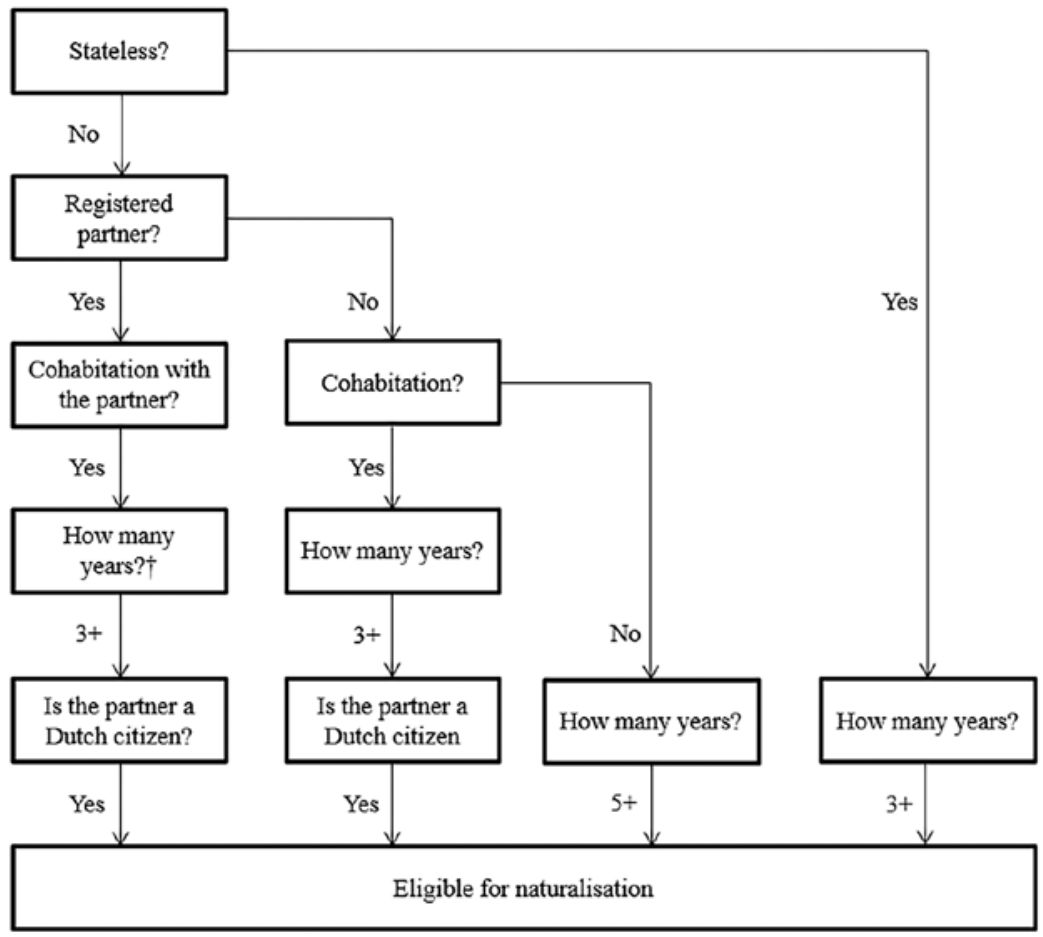

$\dagger$ Include years of cohabitation prior to the registered partnership.

sion in 2003 and the observation period includes the years both before and after the reintroduction of the renunciation requirement. We restrict the sample to foreign-born individuals both of whose parents were born abroad and select only migrants who are 18 years or older at the moment of migration. We only observe migrants once they are eligible for naturalisation. The most important requirements for naturalisation are as follows: an applicant needs to

- be at least 18 years of age;

- be in possession of a non-temporary residence permit;

- have primary residence on the territory of the Netherlands for a period of five years prior to the request for naturalisation (note that there is an exception to the residence requirement - but not primary residence - for applicants who have lived in a stable relationship with a Dutch citizen - see Figure 6.3 for details); 
- pose no danger to public order, good morals or security in the Netherlands; and

- be considered sufficiently integrated into Dutch society based on his or her mastery of the Dutch language or - if residing in the Dutch Antilles or Aruba - the language commonly spoken on the island besides Dutch.

While migrants normally become eligible for naturalisation after five years of residence, they are exempt from this requirement when either:

(a) $s /$ he has been the registered partner of a Dutch citizen and has cohabited with this partner for three years and the partner is a Dutch citizen at the moment of application;

(b) $s /$ he has resided for three years in the Netherlands and has cohabited with a partner for three years and the partner is a Dutch citizen at the moment of application;1" or

(c) $s /$ he is stateless and has resided in the Netherlands for three years.

\section{Figure 6.3. Immigrant cohorts 1985-1997, by dual citizenship regulation of country of origin (in percentages)}

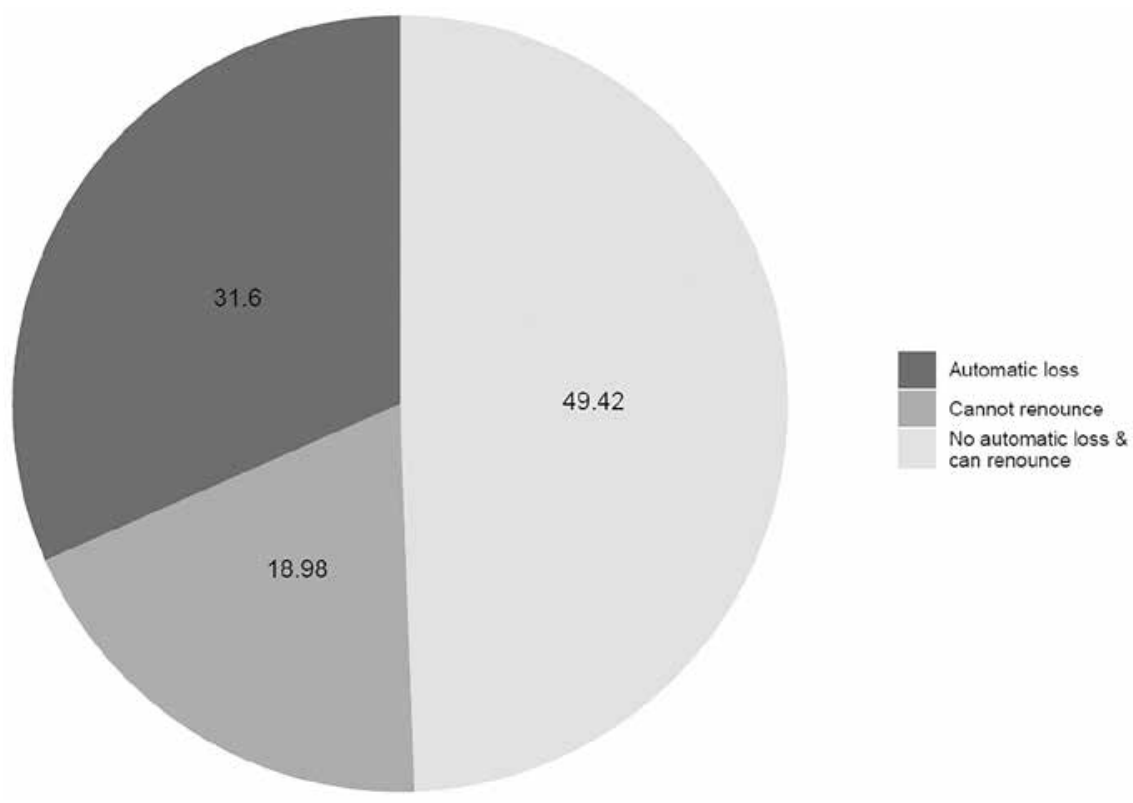

11 While migrants who are in a registered partnership with a Dutch citizen prior to migration to the Netherlands can be eligible in less than three years after migration, Dutch register data do not include information to identify such instances. 
In line with these criteria, the moment of eligibility is dynamically determined as either three, four or five years after migration (based on a residence requirement of five years or three in the case of an exception). The stepwise criteria by which the moment of eligibility is determined are outlined in Figure 6.3. See Table 6.1 in Annex 2 for descriptive statistics on the sample.

\subsection{Empirical strategy}

Our identification strategy is based on a Cox proportional hazards regression model. These models allow the estimation of duration until an event of interest, in this case naturalisation. The main econometric equation is as follows:

$$
h(t)=h_{0}(t) \exp (b x+B z(t))
$$

where $h(t)$ is the hazard function at time $t$, determined by the baseline hazard at time $t$ when all predictors are equal to zero $\left(h_{0}(t)\right)$ and the exponential function of the time-constant $\left(x_{1}, x_{2}, x_{p}\right)$ and time-varying $\left(z_{1}(t), z_{2}(t), z_{p}(t)\right)$ predictors. Note that the latter predictors have an effect that depends on their values at time $t$. Due to our annual observations, the model constitutes a discrete-time survival analysis, where all characteristics are recorded within yearly intervals.

The dependent variable is naturalisation, measured dichotomously as possession of Dutch citizenship. The most important (time-varying) predictor is whether or not an individual loses or has to renounce her/his original citizenship when naturalising in the Netherlands. This is measured with a dummy that is set to unity when, based on citizenship policies in both the origin and host country at time $t$, a migrant does not automatically lose her/his citizenship upon naturalisation and is not required to renounce or cannot voluntarily renounce it (and hence is not required to do so). Conversely, it has value zero if a migrant automatically loses her/his citizenship or is required to renounce it upon naturalisation and can do so. Control variables include gender, age at migration, partner status and the citizenship of the partner, having minor children, the highest level of education, originating from an EU member state, geographic origin regions and migrant cohorts.

\section{Results}

\subsection{Main effect}

The drop in naturalisations in the Netherlands after 1997 has often been associated with the change in dual-citizenship policy (de Hart 2007, 15-16; Entzinger 2006, 126-127; van Oers, de Hart and Groenendijk 2013, 17-18). Yet not all migrants would have to renounce their original citizenship as a result of this policy change, either because they fell under an exception to the requirement or because they could not lose their original 
citizenship due to the origin-country citizenship policy. This is captured in the dynamic dual-citizenship variable, which takes into account policies in both the origin and the host country over time.

Figure 6.4 reveals that migrants who do not lose or cannot renounce their original citizenship upon naturalisation are 12 percentage points more likely to naturalise than their counterparts who lose or have to renounce it, all else being constant. This has been frequently confirmed in the literature and can be explained through the notion of a cost-benefit framework (Labussière and Vink 2020; Mazzolari 2009; Peters, Vink and Schmeets 2016). What is less-well known is the extent to which the opportunity to hold dual citizenship remains important over time, as migrants settle and build their lives in the host country.

Figure 6.5 shows the hazard ratio of migrants who do not lose their original citizenship upon naturalisation compared to those who do by years since migration. While the difference becomes smaller over time, it remains statistically significant even 18 years after migration. This suggests - in line with recent research on second-generation immigrants in the Netherlands (Labussière and Vink 2020) - that restrictions on dual citizenship do not so much delay but, rather, disincentivise migrants from naturalisation altogether, at least during the initial decades after migration.

Figure 6.4. Heterogenous effects of the impact of losing or having to renounce the original citizenship on naturalisation rates among immigrants across different subsamples. Dots denote point estimates, and horizontal lines correspond to $95 \%$ confidence intervals.

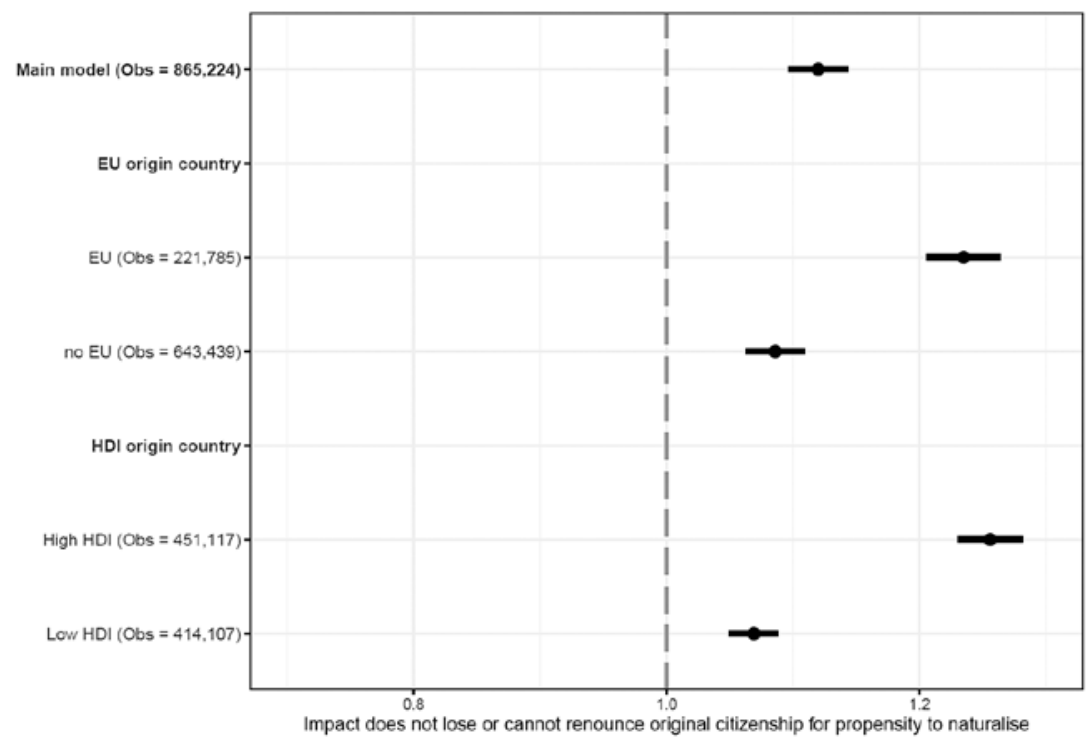




\section{Figure 6.5. Hazard ratio dual citizenship acceptance on immigrant naturalisation} propensity (reference category = immigrant loses or has to renounce origin citizenship) by years since migration

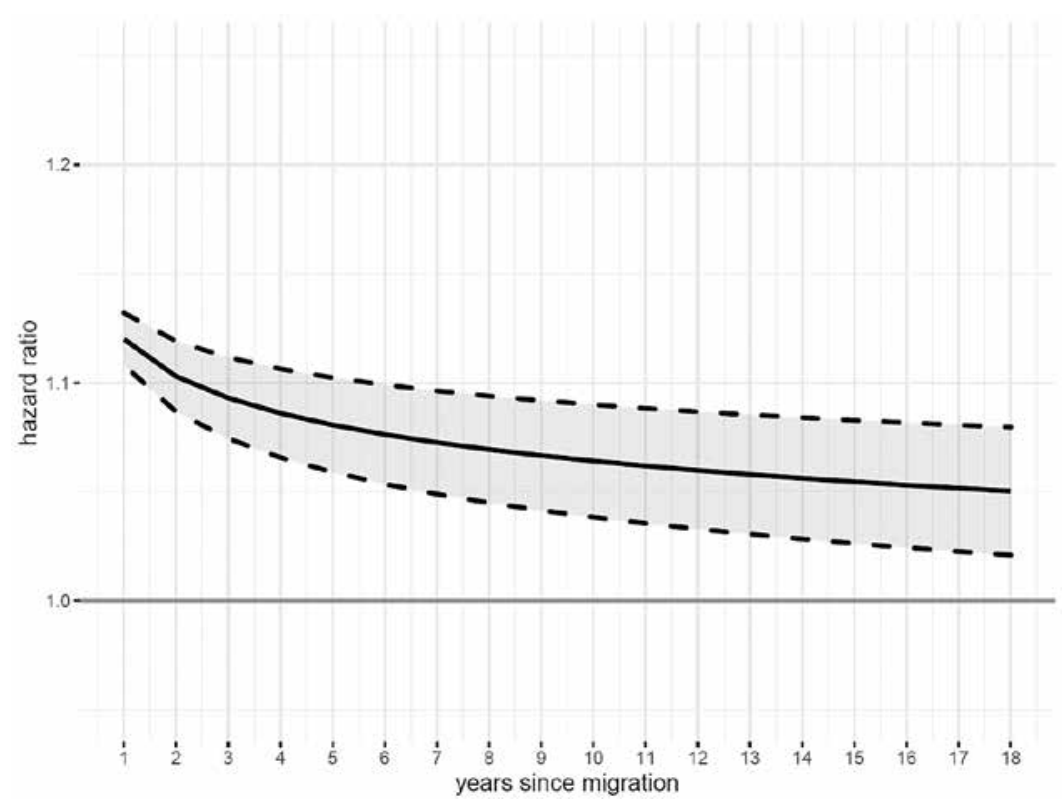

\subsection{Effect heterogeneity}

Previous analyses demonstrate that dual citizenship acceptance has a significant and substantive impact on the propensity to naturalise. To whom, however, does dual citizenship matter the most? Building on the cost-benefit framework informing much of the citizenship acquisition literature (Yang 1994), research shows that a renunciation requirement constitutes an obstacle to naturalisation (Helgertz and Bevelander 2017; Labussière and Vink 2020; Mazzolari 2009; Peters, Vink and Schmeets 2016). Yet from the same theoretical perspective, one could argue that this will be particularly true for migrants whose original citizenship is relatively valuable ${ }^{12}$ such as migrants from the EU or other highly developed countries (Bevelander et al. 2015). We thus perform subgroup analyses for migrants from the EU and associated states with free movement of persons, ${ }^{13}$ as well as for migrants from countries above or below the median Human Development Index (World Bank 2018) score in the sample (Figure 6.4 - see also Table 6.2 in Annex 2).

\footnotetext{
12 See the Quality of Nationality Index (Kochenov and Lindenboom 2020) for an overview.

13 See Annex 1 for details on the operationalisation.
} 


\section{Figure 6.6. Hazard ratio dual citizenship acceptance on immigrant naturalisation propensity (reference category $=$ immigrant loses or has to renounce origin citizenship), by years since migration, for immigrants from EU/non-EU (left graph) and high-/low-HDI (right graph) countries of origin}
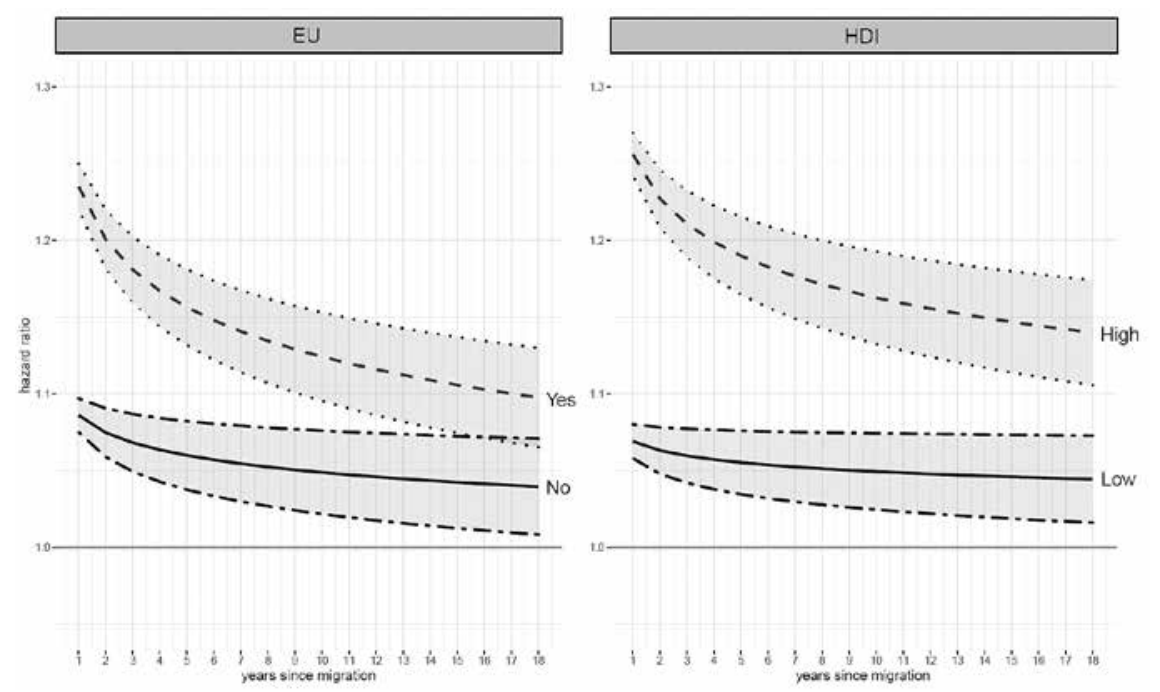

In line with the cost-benefit framework, both migrants from the EU and other countries with a high $\mathrm{HDI}$ score are particularly affected by the policy change. More specifically, the difference in naturalisation propensity between migrants from the $\mathrm{EU}$ who do not lose or cannot renounce their original citizenship compared to those who would lose or are expected to renounce it is 24 percentage points - but only 9 among those from non-EU countries. A similar discrepancy is observed among those from highly and less-developed countries of origin, with a difference of 26 and 7 percentage points respectively. When analysing the extent to which the opportunity to hold dual citizenship continues to matter as migrants reside in the host country, we observe statistically significant differences in the propensity to naturalise during the first 15 years after migration. Subsequently, the confidence intervals of migrants from EU and non-EU countries of origin start to overlap, whereas migrants from highly developed countries continue to have a higher propensity to naturalise than their counterparts. More generally, the importance of retaining the original citizenship upon naturalisation decreases over time, especially among migrants for whom dual citizenship matters the most. Yet the gap in naturalisation propensity only closes slowly. Using a quasi-experimental design, Peters and Vink (2021) show that the heterogenous effect of dual citizenship policy change in the Netherlands and Sweden can be causally interpreted. 


\section{Conclusions}

In this chapter, we build on a well-established literature on dual citizenship acceptance for immigrants' propensity to naturalise. Our findings demonstrate that immigrants in the Netherlands who cannot or are not expected to renounce their original citizenship upon naturalisation are 12 percentage points more likely to naturalise than their counterparts who lose or have to renounce it, all else being constant. Yet there is substantial heterogeneity in the extent to which dual citizenship matters between migrant groups. Drawing on a cost-benefit framework, we expect that dual citizenship acceptance matters particularly for migrants whose original citizenship is valuable and who thus stand to lose the most from its loss or renunciation. Consistent with that notion, we find that the relevance of dual citizenship is much more pronounced among migrants from the EU and associated countries with which the EU shares a freedom of movement regime, as well as among migrants from highly developed countries of origin. Finally, the difference in naturalisation propensity between those who can and those who cannot naturalise while keeping their original citizenship persists even after a substantial period in the host country has passed, suggesting that restrictive dual-citizenship policies disincentivise rather than delay naturalisation. ${ }^{14}$ While the naturalisation gap closes over time, particularly among those for whom dual citizenship matters the most, this process is slow.

These findings have implications for debates about the integration of migrants from both a political and a socio-economic perspective. Dual citizenship was unofficially tolerated in the Netherlands with a view to improving the political participation and legal standing of immigrants. From that viewpoint, the measure was a success, since it led to a dramatic increase in naturalisations, particularly among Turks and refugees (van Oers, de Hart and Groenendijk 2013, 15). The findings in this chapter show that the reintroduction of the renunciation requirement reversed that process, with long-term consequences to the detriment of the political representation of migrants at the national level. The potential ramifications extend beyond the political sphere, however. The extensive field of research on the so-called "citizenship premium" - the positive outcomes associated with naturalisation - suggests that citizenship acquisition has the potential to facilitate the integration of immigrants. Research in the Dutch context shows that naturalisation increases the probability of paid employment (Peters, Vink and Schmeets 2018) and income from labour (Peters, Schmeets and Vink 2019), particularly among migrants from economically less-developed countries of origin, who face structural obstacles in the labour market and for whom the host-country citizenship is a valuable asset to mitigate their disadvantaged position (Hainmueller, Hangartner and Ward 2019). Positive out-

\footnotetext{
14 A recent comparative study shows that this pattern also holds true in the context of liberalising dual-citizenship policy in Sweden (Vink et al. 2021).
} 
comes are not just limited to the labour market; naturalisation increases the probability of homeownership by signalling creditworthiness and attenuating ethnic discrimination in the housing market (Peters 2019). The potential boost that the host-country citizenship might offer to facilitate full participation and integration is lost for those who are disincentivised to naturalise due to the renunciation requirement.

Debates around dual citizenship in the Netherlands remain very much alive today, especially - but by no means exclusively - in the context of Brexit. Pushed by expat communities in the UK and elsewhere around the world, the current government coalition indicated in its governing programme of October 2017 that it planned to introduce a liberalisation of dual citizenship (Rijksoverheid 2017, 6; see also Boffey 2017). However, as of yet, no progress has been made on this proposal and it remains to be seen when, if at all, the Netherlands will finally align itself with the global trend of dual citizenship acceptance. The results of the analysis presented in this chapter suggest that this restrictive policy significantly and substantially affects naturalisation rates and thus political representation among immigrants in the Netherlands.

\section{Acknowledgement}

Work on this chapter was financed by the European Research Council (ERC) through the Horizon 2020 Research and Innovation Program of the European Union (grant agreement number 682626).

\section{References}

Bakker, B., van Rooijen, J. and van Toor, L. 2014. The system of social statistical datasets of Statistics Netherlands: an integral approach to the production of register-based social statistics, Statistical Journal of IAOS, 30(4): 411-424.

Bevelander, P., Helgertz, J., Bratsberg, B. and Tegunimataka, A. 2015. Vem Blir Medborgare och Vad Händer Sen? Naturalisering i Danmark, Norge och Sverige. Stockholm: Delmi Rapport 25:6. http://www.delmi.se/upl/files/119016.pdf.

Boffey, D. 2017. Brexit: Dutch nationals living in Britain will be allowed dual citizenship, The Guardian, 10 October. Available at https://www.theguardian.com/world/2017/ oct/10/dutch-nationals-living-britain-allowed-dual-citizenship-brexit.

De Hart, B. 2007. The end of multiculturalism: the end of dual citizenship? Political and public debates on dual citizenship in the Netherlands (1980-2004), in Faist, T. (ed.) Dual Citizenship in Europe. Aldershot: Ashgate, 77-103.

Entzinger, H. 2006. Changing the rules while the game is on: from multiculturalism to assimilation in the Netherlands, in Bodemann, Y.M. and Yurdakul, G. (eds) Migration, Citizenship, Ethnos: Incorporation Regimes in Germany, Western Europe and North America. New York: Palgrave Macmillan, 121-144. 
Hainmueller, J., Hangartner, D. and Ward, D. 2019. The effect of citizenship on the longterm earnings of marginalized immigrants: quasi-experimental evidence from Switzerland, Science Advances, 5(12): 1-8.

Heijs, E. 1995. Van Vreemdeling tot Nederlander: De Verlening van het Nederlanderschap aan Vreemdelingen 1813-1992. Amsterdam: Het Spinhuis.

Helgertz, J. and Bevelander, P. 2017. The influence of partner choice and country of origin characteristics on the naturalization of immigrants in Sweden: a longitudinal analysis, International Migration Review, 51(3): 667-700.

Jones-Correa, M. 2001. Under two flags: dual nationality in Latin America and its consequences for naturalization in the United States, International Migration Review, 35(4): 997-1029.

Kochenov, D. and Lindenboom, J. 2020. Kälin and Kochenov's Quality of Nationality Index. An Objective Ranking of the Nationalities of the World. Oxford: Hart Publishing.

Labussière, M. and Vink, M. 2020. The intergenerational impact of naturalisation reforms: the citizenship status of children of immigrants in the Netherlands, 1995-2016, Journal of Ethnic and Migration Studies, 46(13): 2742-2763.

Mazzolari, F. 2009. Dual citizenship rights: do they make for more and richer citizens? Demography, 46(1): 169-191.

Ministerie van Veiligheid en Justitie 2012. Trendrapportage Naturalisatie en Optie: Ontwikkelingen in de Periode 2007-2011. Available at https://ind.nl/Documents/Trendrap_natu_2012.pdf.

Peters, F. 2019. Naturalisation and transitions to homeownership: signalling and legal status discrimination in the Dutch housing market, Housing Studies, 35(7): 1239-1268.

Peters, F. and Vink, M.P. 2016. Naturalisation and the socio-economic integration of immigrants, in Freeman, G.P. and Mirilovic, N. (eds) Handbook on Migration and Social Policy. Northampton: Edward Elgar, 362-376.

Peters, F. and Vink, M.P. 2021. Heterogeneous effects of dual citizenship acceptance on immigrant naturalisation: quasi-experimental evidence from two European policy reforms. OSF pre-prints. https://doi.org/10.31219/osf.io/skvfp.

Peters, F., Vink, M.P. and Schmeets, H. 2016. The ecology of immigrant naturalisation: a life course approach in the context of institutional conditions, Journal of Ethnic and Migration Studies, 42(3): 359-381.

Peters, F., Vink, M.P. and Schmeets, H. 2018. Anticipating the citizenship premium: before and after effects of immigrant naturalisation on employment, Journal of Ethnic and Migration Studies, 44(7): 1051-1080.

Peters, F., Schmeets, H. and Vink, M.P. 2019. Naturalisation and immigrant earnings: why and to whom citizenship matters, European Journal of Population, 36: 511-545.

Rijksoverheid 2017. Vertrouwen in de Toekomst: Regeerakkoord 2017-2021. The Hague: Ministerie van Algemene Zaken. 
Van den Bedem, R. 1993. Motieven voor Naturalisatie: Waarom Vreemdelingen uit Diverse Minderheidsgroepen wel of niet Kiezen voor Naturalisatie. The Hague: WODC.

Van Oers, R., de Hart, B. and Groenendijk, K. 2013. Country Report: The Netherlands. Florence: Robert Schuman Centre for Advanced Studies, EUDO Citizenship Observatory.

Vink, M., de Groot, G.-R. and Luk, N.C. 2015. MACIMIDE Global Expatriate Dual Citizenship Dataset. DOI:10.7910/DVN/TTMZ08, Harvard Dataverse, V4 [2019].

Vink, M., Schmeets, H. and Mennes, H. 2019. Double standards? Attitudes towards immigrant and emigrant dual citizenship in the Netherlands, Ethnic and Racial Studies, 42(16): 83-101.

Vink, M., Schakel, A.H., Reichel, D., Luk, N.C. and de Groot, G.-R. 2019. The international diffusion of expatriate dual citizenship, Migration Studies, 7(3): 362-383.

Vink, M., Tegunimataka, A., Peters, F. and Bevelander, P. 2021. Long-term heterogeneity in immigrant naturalisation: the conditional relevance of civic integration and dual citizenship, European Sociological Review. https://doi.org/10.1093/esr/jcaa068.

World Bank 2018. World Development Indicators Database. Washington, DC:World Bank. WRR 1989. Allochtonenbeleid. The Hague: SDU Uitgeverij.

Yang, P.Q. 1994. Explaining immigrant naturalization, International Migration Review, 28(3): 449-477. 


\section{Annex 1. Operationalisation of variables}

Notes on the operationalisation of some of the covariates:

- Years since migration: due to the annual observations on 01 January of each year, the first observation of each individual is, in most cases, labelled as zero, unless a migrant came to the Netherlands on 01 January.

- Partner: we distinguish between migrants with no registered partner on the one hand and those with, respectively, either a native partner, a foreign-born naturalised partner or a foreign-born non-naturalised partner. We distinguish the partner by citizenship status in order to capture household dynamics of naturalisation, as migrants often naturalise together (Helgertz and Bevelander 2017; Peters, Vink and Schmeets 2016).

- Highest achieved level of education: operationalised as follows: individuals with a low education level received only primary or lower-secondary education. Individuals with a medium education level include those with upper-secondary, post-secondary and high vocational education; those with a high educational level finished a postgraduate education or higher. While the level of education technically varies over time within individuals, variation in the host country among foreign-born individuals who migrated after the age of 18 is minimal. We thus focus on the highest achieved education. Information on education is missing for a substantial group of individuals in the Netherlands (51 per cent), for whom we include a separate category labelled "education unknown".

- EU: binary variable capturing whether (1) or not (0) in a particular year, a country is a member state of the European Union or one of the associated states with which the EU shared a free movement regime: Austria, Belgium, Denmark, Finland, France, Germany, Greece, Ireland, Italy, Luxembourg, the Netherlands, Portugal, Spain, Sweden, the United Kingdom (EU) + Iceland, Norway (1994: EFTA/EEA) and Liechtenstein (1995: EFTA/EEA).

- HDI: based on the Human Development Index, HDI is a three-dimensional measurement of the socio-economic conditions in a country, based on indicators for health, knowledge and standard of living. The composite index provides a score from 0 to 1, where a higher score equals greater development (World Bank 2018). This is dichotomised around the median of the sample into low and high HDI.

- Dual citizenship: information is derived from the MACIMIDE Global Expatriate Dual Citizenship Database (Vink, de Groot and Luk 2015), which provides detailed information on nearly all countries in the world over time regarding the loss or renunciation of citizenship after a citizen of a state voluntarily acquires the citizenship of another state. 


\section{Annex 2. Descriptive statistics and regression models}

Table 6.1. Descriptive statistics, cohorts 1985-1997

\begin{tabular}{|c|c|c|}
\hline \multirow[t]{2}{*}{ Naturalised } & Yes & 63.73 \\
\hline & No & 36.27 \\
\hline \multirow[t]{2}{*}{ Gender } & Male & 42.28 \\
\hline & Female & 57.72 \\
\hline \multirow[t]{4}{*}{ Age at migration } & $18-30$ & 64.72 \\
\hline & $31-40$ & 23.95 \\
\hline & $41-50$ & 8.35 \\
\hline & $50+$ & 2.98 \\
\hline \multirow[t]{4}{*}{ Partner } & No partner & 22.57 \\
\hline & Foreign-born foreign partner & 27.60 \\
\hline & Foreign-born Dutch partner & 22.26 \\
\hline & Native partner & 27.57 \\
\hline \multirow[t]{2}{*}{ Minor children } & Yes & 62.39 \\
\hline & No & 37.61 \\
\hline \multirow[t]{4}{*}{ Highest level of education } & Low & 32.77 \\
\hline & Middle & 15.34 \\
\hline & High & 9.91 \\
\hline & Unknown & 41.97 \\
\hline \multirow[t]{3}{*}{ Origin dual citizenship policy } & Automatic loss & 31.60 \\
\hline & Cannot renounce & 18.98 \\
\hline & No automatic loss and can renounce & 49.42 \\
\hline \multirow[t]{2}{*}{ EU country of origin } & Yes & 25.63 \\
\hline & No & 74.37 \\
\hline \multirow[t]{6}{*}{ Origin regions } & Europe & 33.44 \\
\hline & North America and Oceania & 2.74 \\
\hline & South America and Caribbean & 6.48 \\
\hline & Africa & 23.28 \\
\hline & Asia & 8.19 \\
\hline & Middle East & 25.87 \\
\hline \multirow[t]{2}{*}{ Human Development Index } & High & 52.14 \\
\hline & Low & 47.86 \\
\hline \multirow[t]{7}{*}{ Immigration year } & 1985 & 4.83 \\
\hline & 1986 & 6.34 \\
\hline & 1987 & 7.07 \\
\hline & 1988 & 8.07 \\
\hline & 1989 & 9.06 \\
\hline & 1990 & 9.56 \\
\hline & 1991 & 8.56 \\
\hline
\end{tabular}




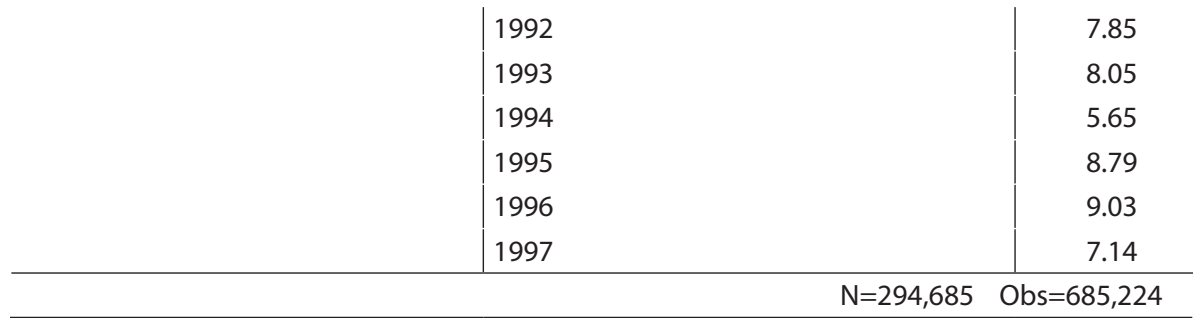

Source: Statistics Netherlands 


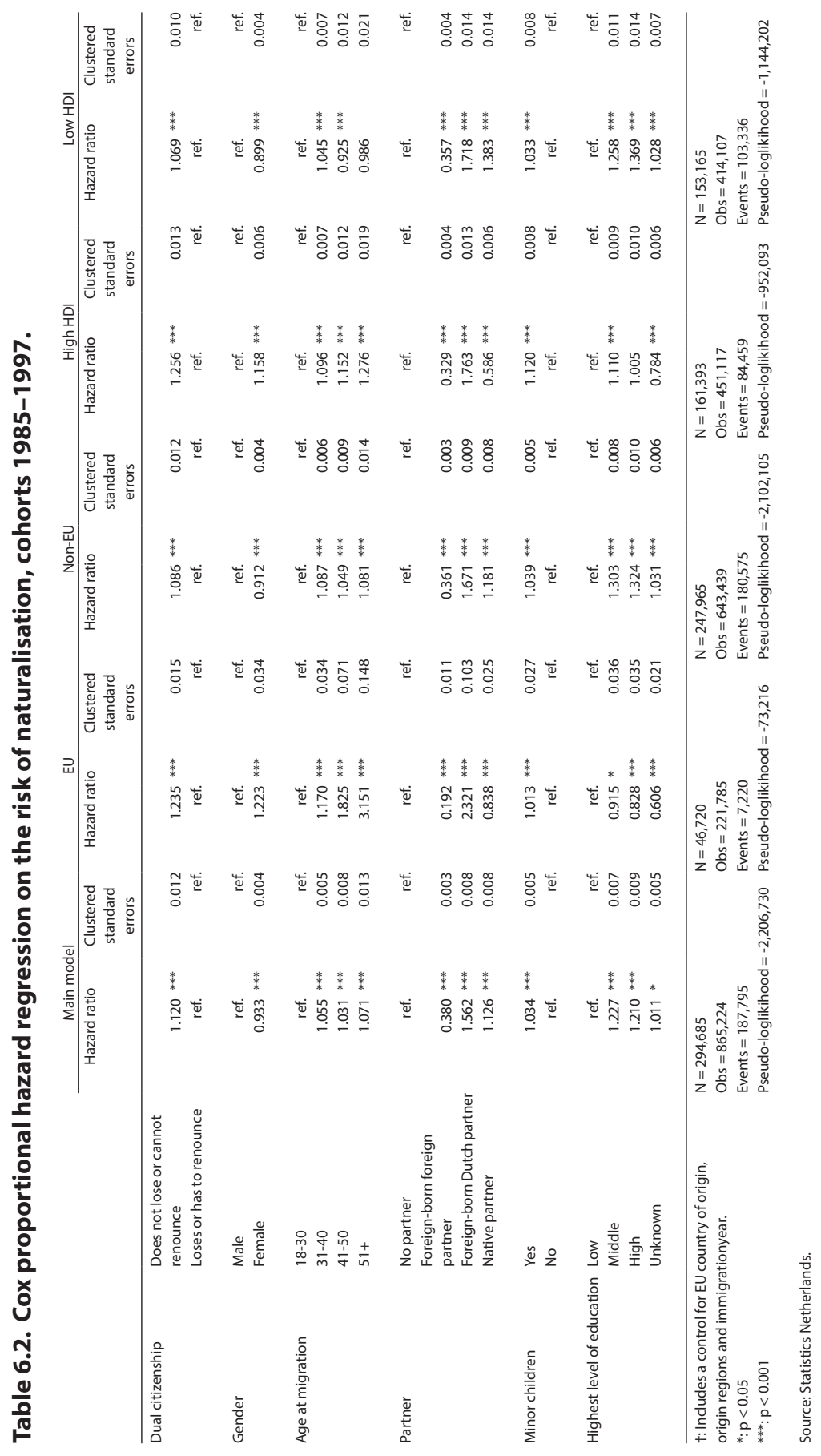




\title{
Chapter 7
}

\section{Kin Citizenship in Eastern Europe ${ }^{1}$}

\author{
Szabolcs Pogonyi, Associate Professor, Central European University, Vienna
}

\begin{abstract}
As opposed to Western and North American immigration countries, where dual citizenship has been discussed in relation to migrant's integration, Eastern European states used external dual citizenship polices as part of post-communist nation-building projects. In Eastern Europe, newly restored states as well as countries whose international borders have not been involved in recent territorial changes offered citizenship for their ethnic kin living beyond the borders in order to strengthen the claims of the titular majorities over the state, thereby creating ethnocracies. This chapter gives a short overview of kin-citizenship policies in Eastern Europe and argues that the inclusion of non-resident populations in the demos as part of fast-track nation-building generates internal democratic deficits and diplomatic skirmishes but rarely results in outright interstate conflict. The chapter also points out that individuals often regard kin citizenship very differently from governments that offer it as part of transborder nationalist projects.
\end{abstract}

\section{Introduction}

In past decades, dual citizenship has received ample political as well as scholarly attention. These debates, however, focused mostly on the question of whether immigrants naturalising in their new home states should have the right to retain their citizenship in their countries of origin. In the immigration context, the main dilemma has been whether and how the retention of citizenship in the country of origin impacts on social and political integration in the countries of immigration. Not surprisingly, right-wing nationalist governments in immigration countries are more likely to oppose dual citizenship, assuming that having formal membership in two states could weaken immigrants' political allegiance and make it more difficult for them to integrate while, at the same time, dual citizenship may also weaken national sovereignty (Pogonyi 2011). Left-wing and liberal parties, on the other hand, often claim that the toleration of dual citizenship will incentivise immigrant naturalisation and facilitate the social integration of newcomers, while also recognising multicultural diversity.

1 The author acknowledges partial funding of research for this chapter by the NFKI 13496 project Legal Approaches to Operationalize Nationality and Ethnicity. 
Despite the diametrically opposing views, both sides take it for granted that formal citizenship status has important implications for the allegiance of individuals as well as "an expression of a state's identity" (Džankić 2015, 183). Indeed, it would be hard to deny that citizenship, the legal bond between a state and an individual, determines the life prospects of the individual (Shachar 2009). On the other hand, citizenship policies that decide who is in and who is out in terms of membership also shape the state. In international relations, sovereign states are marked as territories as well as bounded populations. States are not only territorial units but also a "body politic" constituted by individuals who are, in democracies at least, considered equal members of the political community. While Westphalian sovereignty implies that no external powers may interfere with the internal issues of states, popular sovereignty means that state power should be used democratically - that is, in the name and interests of the people. The creation of a bounded population, therefore, is at least as essential for states as maintaining territorial sovereignty. As we know from Rogers Brubaker's seminal work, formal citizenship attribution rules define the nation that the territorial state is supposed to represent and serve. The way the demos is demarcated at state independence has long-term implications for statehood (Brubaker 1992). Citizenship attribution policies determine who belongs to the people who legitimately exercise power through the state. The struggle for membership is also a struggle for power: those who become citizens will have the right to shape the nation that the state stands for. In contemporary politics, struggles over membership surface the most often in relation to immigration. Even those countries that are relatively open in territorial terms restrict access to citizenship and regulate who can become a full and legally equal member of the national demos, how and when. Thus, citizenship policies are one of the most salient means of nation- as well as state-building in countries of immigration.

Since 1989, citizenship attribution policies in Eastern Europe have become fields of contestation not because of immigration but due to state succession and democratic transition. Despite the divergent paths to democratisation and regardless of whether newly regained freedom involved border changes, national sovereignty became intertwined with democratic transition in the whole post-communist region. Histories of fragile statehood and legacies of foreign occupation resulted not only in "state-reinforcing overcompensation" (Liebich 2009, 22) but also feverish nation-building. For most Eastern European countries, democratic transition and the restoration of sovereignty were parallel and intertwined processes. In the newly independent states, internal self-determination was conditional on regaining external self-determination and thus it is less than surprising that the maintenance of sovereignty has become a central political concern in the newly restored states. Ironically, as the Iron Curtain fell, sovereignty-related anxieties intensified not only in the Yugoslav and Soviet successor states where new international borders were erected but also in those countries whose borders became more permeable. The end of communism was perceived as "a process of national liberation" throughout Eastern 
Europe (Bunce 1995, 120). The formation of the demos was portrayed as the completion of the freedom struggles, framed as ethnocultural and/or ethnoreligious projects (Verdery 1998). Independent statehood was meant to achieve the sovereignty of core national groups. "Stories of peoplehood" (Smith 2003) were told as stories of nationhood. As part of the transition to democracy, all post-communist Eastern European parliaments rewrote or significantly amended their constitutions. The new basic laws in the post-communist region were designed not only to entrench basic democratic rights and the rule of law but also to secure the core national group's claims on the state (Elster 1991). Despite the differences in economic development, paths to democratisation, ethnic composition, the volume of prior ethnic violence and state continuity, most Eastern European countries reached back to pre-communist times in order to underline the continuity of the nation (ibid., 476). The constitutional identities of Eastern European states (with the notable exception of the Czech Republic (Přibáň 2004, 426-427) were defined in ethnocultural and/or ethnoreligious idioms. As Kissane and Sitter - using Gellner's four time periods of nationalism (Gellner 1983) - argue, in Eastern European states, latecomers to liberal democracy, "a marriage between state and nation has emerged" (Kissane and Sitter 2010, 60). Most preambles to Eastern European constitutions claim that national self-determination is an inalienable right of the nation and sovereignty is necessary in order to protect and secure the survival of the majority nation's language and culture.

\section{Citizenship and nation-building in Eastern Europe}

In order to strengthen the domination of the core nation, newly independent states tried to marginalise internal minorities. The redrawing of state borders along putatively national lines transfigured rather than resolved ethnic conflicts in the region. Elections in ethnically divided democratic transition states often entrench ethnic cleavages (Snyder 2000). When independent statehood was achieved, state-seeking nationalisms were transformed into nationalising nationalisms, while new minorities that had opposed secessionist movements embraced pro-independence minority nationalism. The logic of divergent nationalist projects after the dissolution of former Socialist federations resulted in competing and conflicting nationalisms that intensified one another (Brubaker 2011). In Eastern Europe, minority nation-building became a highly securitised issue as ethnic minorities (particularly those with kin states) were widely considered "fifth columns" for foreign powers and a potential threat to national security as well as national culture (Džankić 2015; Kymlicka 2004; Skulte-Ouaiss 2015).

Citizenship attribution policies became a major nation-building tool after the breakup of the Soviet Union and Yugoslavia. In the two Eastern European federations, internal migration was not strictly controlled. In the Soviet Union internal relocation was even facilitated and forced displacement was sometimes also applied, which resulted in the creation of large internal diasporas. As a consequence of the historical mixing of ethnic groups, after the break-up of the socialist federations, large ethnic minorities were created 
in the newly independent states. While, during federal times, republic-level citizenship status (citizenship in one of the constituent entities within the federation) had little practical importance and was, in most cases, very poorly administered (Stiks 2010, 12), at the creation of the new sovereign states the question of citizenship became highly relevant. Republic-level membership status was often the primary determining factor of subsequent citizenship in the successor states. When the former Socialist Republics dissolved, the mostly administrative internal borders became international borders and, consequently, internal diasporas became ethnic minorities in the new states. Quite often, the new nationalising states used selective citizenship policies to exclude ethnic minorities from the demos. Russian populations were denied citizenship after independence in Estonia and Latvia, which downgraded them to the status of newly arrived immigrants (Jarve and Poleshchuk 2013; Kruma 2010; Pettai and Hallik 2002; Smith 2003). Similarly to the Baltic countries, citizenship attribution was used with the purpose of ethnic engineering in South-East Europe after the dissolution of the Yugoslav federation. ${ }^{2}$ National independence in the post-Yugoslav states was proclaimed and glorified in the name of the nation and defined in ethnocultural or ethnoreligious (Radović 2013) terms. In the post-Yugoslav citizenship struggles, democracy was meant to be practiced within the titular national group (Stiks 2010). A good illustration of "ethnic engineering" (Stiks 2010) through citizenship is the Croatian law on citizenship, enacted in 1991, which made it very difficult, if not impossible, for ethnic Serbs without republic-level citizenship to naturalise in Croatia (Koska, Ragazzi and Stiks 2013). To a lesser extent, ethnocentric nation-building through selective citizenship policies was practiced even in ethnically relatively homogenous Slovenia, where 18,305 mostly ethnically non-Slovene individuals lost their citizenship and became stateless after being erased from all public registries (Medved 2013). Restrictive naturalisation measures were in place, even in Montenegro, in order to deprive ethnic Serbs who had fled from Croatia and Bosnia, so that Serbs who were more likely to be pro-union would not have the chance to vote (Džankić 2012). Although large-scale ethnic engineering was not present in the negotiated Czechoslovak break-up, citizenship attribution here, too, was used for the exclusion of the unwanted Roma minority (Summers 2014).

The use of citizenship for nation-building purposes was not confined to new and newly restored states that used internally restrictive citizenship policy to exclude members of ethnic minorities from the demos. In order to strengthen the titular majority's claim over the state and to strengthen their national/nationalist image, governments considered it as a priority to help their ethnic kin in the neighbouring states. The help

2 For detailed comprehensive reports, comparative analyses and case studies of citizenship regimes, see the working papers of the University of Edinburgh's project The Europeanisation of Citizenship in the Successor States of the Former Yugoslavia (CITSEE) at http://www.citsee. ed.ac.uk/. 
of transborder kin minorities was also used to symbolically distance the democratically elected governments from the past communist regimes that had not paid much attention to these groups. Transborder engagement in the form of symbolic engagement, political activism and the preferential treatment of ethnic kin populations not only fit well with the nationalist narratives but were used as a tool to deconstruct the symbolic boundaries that divided Europe during the Cold War.

After 1989, however, most countries of the region - including Hungary, Bulgaria, Romania, Serbia, Slovenia, Slovakia, Croatia, Macedonia, Poland, Ukraine and Russia adopted amendments to their constitutions, assuming special responsibility for the protection of kin minorities living in foreign countries. Albania, Hungary, Slovakia, Romania, Bulgaria, Poland, Serbia and Slovenia introduced additional benefits laws or external quasi citizenship rules (Bauböck 2007) that grant special privileges to co-ethnic minorities in neighbouring countries who do not possess formal citizenship.

In some cases, post-communist governments facilitated the repatriation or the formal inclusion of external kin populations in the demos through external citizenship. As part of the consolidation process, it seemed reasonable that émigrés, who had often helped the independence movements (by sending money and/or lobbying for the recognition of the new states), should be offered full citizenship. Many of the former socialist countries allowed external dual citizenship so that migrants could re-establish former legal ties with their democratising home countries. Others introduced preferential citizenship policies or facilitated the resettlement of expatriates and diasporas (Liebich 2009).

All EU-13 new member states give privileged access to their citizenship to descendants of emigrants or persons with close cultural affinity - or have at least done so for a certain period after 1989. A number of states in the region have introduced preferential access to citizenship for ethnic kin, while others have adopted external citizenship policies which, by removing residence requirements, have significantly expanded the size of the potential or actual citizenry of the homeland state and created an ethnically defined population in transborder areas. One special feature of kin citizenship policies in Eastern European states relates to the relative demographic weight of external kin populations compared to the size of homeland populations. Under Bulgaria's rules on ethnic Bulgarians, around two-thirds of Macedonia's population of 2 million are eligible for Bulgarian citizenship on a preferential basis, though the number of Macedonian citizens who have acquired Bulgarian citizenship remained relatively low until 2010 (Hristova 2010). Between 2002 and 2011, a total of 44,211 Macedonian citizens were granted Bulgarian citizenship on the grounds of Bulgarian origin, while another 20,668 individuals from Moldova were naturalised in the same period (Jileva and Smilov 2013). It is quite telling that 40 per cent of those naturalised in 2012 had no permanent residence in Bulgaria (Jileva and Smilov 2013). Under Romanian rules, 2.5 million Moldovans out of 4 million are eligible for Romanian external citizenship and, under Hungarian rules, over 2.5 million ethnic Hungarians in neighbouring states are eligible for Hungarian kin citizenship. 
While, in the case of Romania, the number of those Moldovans who have already acquired the status of external citizens remains less than one third of all those eligible, the majority of Croats in Bosnia possess external citizenship in Croatia (Koska, Ragazzi and Stiks 2013). Those eligible for Serbian external citizenship amount to over 2 million compared to the 6.2 million population of the Republic of Serbia: almost the entire population of the Bosnian Serb Republic and a third of the population of Montenegro are eligible for external Serb citizenship (Rava 2013). According to Moldovan estimates, applications by Moldovan citizens for Romanian citizenship are between 800,000 and 1.5 million. The number of those Moldovan citizens who had already acquired Romanian citizenship by 2010 is over 300,000, while another 120,000 Moldovans had Russian citizenship (Gasca 2012). At least in some states of the region, for instance in Moldova, the eligible target groups of external citizenship policies may comprise the numerical majority of the population of the state in which the target group resides. In other cases, such as the Bosnian Serb Republic, the numerical majority of an autonomous sub-state unit is eligible for the external citizenship of another state.

Following the dissolution of the Soviet Union, Russia also instituted generous external citizenship policies towards former citizens of the Soviet Union who found themselves minorities in states outside Russia. Russian laws on citizenship allowed residents of former Soviet republics to apply for citizenship if they had not become citizens of their newly independent states, regardless of their ethnic affiliation (Traunmüller and Agarin 2015). However, until 2002, the procedure was very complicated and involved several trips to Russian consular offices or moving to Russia. From 2002, an amendment to the law on citizenship introduced a simplified procedure of citizenship acquisition for former citizens of the Soviet Union if they resided in any of the former Soviet republics and were not able to acquire citizenship from them - and thus remained stateless. After 2002, such individuals were admitted to Russian citizenship upon submission of a written petition to a Russian consular office in the republic of their permanent residency, where they received Russian passports as a proof of their Russian citizenship. At the same time, however, the 2002 reform introduced a restriction according to which those taking up Russian external citizenship had to renounce their former citizenship (Zelev 2008). Until 2002, an estimated 1 million former Soviet citizens received external Russian citizenship, among them around 200,000 in the Ukraine, 200,000 in Abkhazia, 50,000 in South Ossetia, 135,000 in Transnistria and close to 100,000 in Estonia. More recently, like the trend observed in Romania, the Russian Duma adopted legislation in July 2010 that narrows down eligibility for the status of Russian "compatriot living abroad" to ethnic Russians, thus excluding those non-Russians who held citizenship of the Soviet Union in the past.

Transborder nation-building through citizenship was absent in Bosnia Herzegovina, Macedonia and Montenegro. This, however, should not be taken as an indication of ethnically less-biased citizenship regimes. These newly independent and restored post-communist countries feared that the introduction of external kin citizenship would 
propel their own internal minorities to become more vocal in demanding external citizenship from neighbouring kin states (Džankić 2015; King and Melvin 2000). Thus, even in these cases, the absence of expansive kin-citizenship policies is explained by strategic ethnocultural nation-building efforts rather than the recognition of ethnically neutral citizenship norms.

Quite remarkably, kin citizenship has been used as a nation-building tool well beyond the early years of democratic transition, even in countries that were not impacted on by the recent redrawing of international borders. In 2010, less than a week after the inaugural session of the new House, the newly elected right-wing nationalist Fidesz government led by Viktor Orbán introduced kin citizenship for Hungarians living outside the country in the name of "national reunification beyond the borders" (Pogonyi 2017). Subsequently, the new Hungarian Constitution enacted in 2011 defined non-resident Hungarians as full and equal members of the Hungarian nation. The new Act on the Election of Members of the Parliament of Hungary, adopted by parliament in late 2011, offered passive and active voting rights for Hungarians living outside the borders of the country. In the government's rhetoric, the primary aim of this scheme was to redress past injustices suffered by Hungarians who lost their citizenship due to the redrawing of the borders in the 1920 Trianon Peace Treaty after World War I. The formal inclusion of ethnic Hungarians living in the neighbouring countries and overseas territories was also intended to establish a legal bond and institutionalise solidarity among members of the Hungarian "transnation". The Fidesz government claimed that it is a moral duty for Hungary to help Hungarians living outside the country even at the price of exerting pressure on the governments of the neighbouring states. By 2018, more than 1 million Hungarians living outside the country had acquired non-resident citizenship. In the April 2014 parliamentary elections, Fidesz received more than 95 per cent of the non-resident votes, which secured one additional seat for the right-wing party. As Fidesz won exactly the number of seats necessary for an absolute majority, the luminaries of the party, including Orbán, could claim that non-resident Hungarians helped his government to reach a two-thirds majority in parliament, making it possible for the Orbán government to rewrite the constitution.

\section{Kin citizenship: geopolitical implications}

As I have argued elsewhere, kin citizenship creates serious normative dilemmas (Pogonyi 2017). Most importantly, the enfranchisement of external kin minorities has, in a number of homeland states, literally become an instrument of domestic political competition, with political parties recruiting supporters through external electoral engineering. Consequently, the enfranchisement of external kin minorities who have been granted kin citizenship has raised questions with regards to the functioning of electoral institutions within the homeland states. In the past few years, serious concerns have emerged in 
relation to the possible effects of extraterritorial citizenship on electoral processes and results (Bauböck 2007). External dual citizens with voting rights, who do not bear the cost of political decisions, may determine the result of elections and thereby outvote certain parts of the domestic constituencies. In countries with large external kin minorities, such as Hungary, Serbia, Croatia, Romania and Bulgaria, the enfranchisement of external kin minorities has already led to the serious consequence that external voters acquire an unduly large influence on domestic electoral outcomes without actually being exposed to most of the political consequences of their votes.

In addition to compromising democratic self-rule, kin citizenship is often seen as a grave challenge to the international system. As Kymlicka points out, the securitisation of ethnic relations is more likely in the historically contested regions of post-communist Eastern Europe, where fears over the rise of irredentist kin politics are still present (Kymlicka 2007). These threats are often exaggerated by nationalist parties in order to stir up securitised anxieties and incite hatred against minorities with kin states. However, fears that the passportisation of external populations is a precursor to territorial revisionism have gained salience in the aftermath of Russia's intervention in Georgia in 2008. The Kremlin claimed that Russia had a duty to protect ethnic Ossetians with Russian citizenship who were living in Georgia. As the Russian passportisation project shows, the naturalisation of transborder communities (including ethnic kin and other populations) can be used as a "foreign policy weapon" (Mühlfried 2010; Simon 2013).

From 1989, when Romania offered citizenship to ethnic kin groups in Moldova and the Ukraine, it did so in the expectation of a gradual and negotiated process of unification between Moldova and Romania (lordachi 2004). The topic of the future unification of Romania and Moldova has again emerged on the public agenda, promoted, among others, by former Romanian President Traian Băsescu, whose electoral victory in December 2009 was partly secured by external voters from Moldova. More recently, former Romanian President Băsescu urged the reunification of Romania and Moldova, claiming that the "nation [...] lives artificially in two states" as a lasting result of the Ribbentrop-Molotov pact (Băsescu 2016) . In order to further strengthen the symbolic unity of the supposedly divided nation, Băsescu and his wife applied for Moldovan citizenship (Chiriac 2016; Vlas 2016). In an interview, Băsescu said that "Romania is obliged to unite with the Republic of Moldova, to let the latter continue its European path" (Băsescu 2016) which was criticised by Russia as well as pro-Russian opposition politicians in Moldova (Bird 2015). In 2015, 41 Romanian MPs formed the Friends of the Union group to increase cooperation between Romania and Moldova and to pave the way for re-unification (Bird 2015). In the same year, Romania offered EUR 100 million in aid to Moldova (Bird 2015). According to a 2013 poll, 76 per cent of Moldovans support unification with Romania and only 6 per cent oppose it. In another survey from 2015, 68 per cent agreed with the suggestion that the two countries should be united by 2018 , the centenary of the establishment of Greater Romania (Mihalache 2015). Despite the overwhelming support, it cannot be 
taken for granted that the reunification of Romania and Moldova would be as peaceful as the reunification of Germany. Russians in Moldova do not want their country to unite with Romania but, rather, with Russia. In 2014, after the annexation of Crimea by Russia, Transnistrian politicians asked the Russian parliament to extend Russian citizenship to the residents of Transnistria and draft a new law so that the breakaway region could join Russia (BBC News 2014). According to different estimates, around 200,000 individuals in Transnistria have Russian citizenship and another 150,000 possess a Ukrainian passport (Kolsto 2014). Interestingly, Yevgeny Shevchuk, the elected President of the breakaway region, has Russian citizenship rather than Moldovan (Euronews 2014). In 2009, President Băsescu initiated the simplification of naturalisation procedures in order to speed up and broaden the scope of naturalisation of Moldovans so that they could become full members of the "European family" (EurActif.Com 2009).

Regulations on Serbian kin citizenship put Serbian-Montenegrin relations under strain (Džankić 2012). While Serbia extended citizenship to the Serbs of Montenegro, Montenegro insisted that its citizenship will be terminated for those residents in the country who acquire Serbian kin citizenship (Džankić 2010). Given the expansive thrust of Serbian citizenship legislation, one can interpret the text of the law in a way that allows "almost the whole population of the Republic of Srpska and more than a third of the Montenegrin population to become citizens of Serbia" (Rava 2013, 23). Serbian citizenship policy clashes with the restrictive regulations of Montenegro, making it impossible to reach a consensus on (possible) dual citizens of the two states. Serbia does not grant access to the list of Serbian-Montenegrin dual citizens while, at the same time, Montenegro insists that the Montenegrin citizenship of those who have external Serbian citizenship will be terminated (Rava 2013, 23).

With regards to external Serbs in Kosovo, the problem is even more complicated. Although Serbia does not recognise Kosovo's statehood and regards all citizens of Kosovo as citizens of Serbia, it has bowed to European pressure to exclude Serbs in Kosovo from the Schengen visa agreement with Serbia (Rava 2013, 25).

Kin citizenship may also be used in order to contest sovereign statehood. Bulgaria's kin citizenship offered to Macedonians who declare that they have "Bulgarian consciousness" is intended to delegitimise the existence of a separate Macedonian nation which Bulgaria does not recognise (Jileva and Smilov 2013, 16; Koneska 2015; Özgür Baklacıoğlu $2004,336)$. In Russia, non-resident citizenship was introduced partly as a reaction to the growing popularity of the far-right. The legal inclusion of former Soviet citizens, however, also served "neo-imperialist" Russia in projecting geopolitical influence in its near-abroad (King and Melvin 2000, 121).

It should, however, be noted that, in all the above cases, the source of interstate tension is not kin citizenship per se. In the study of nationalism and ethnic relations, violent conflicts dominate the scientific discourse even if they are relatively rare (Brubaker 1998) and only scant attention is given to the banal (Billig 1995) but more regular "weak" 
forms of nationalism that do not lead to ethnic conflict (Todorova 2015). As King and Melvin point out, in post-communist Europe, "diaspora politics may be more a result of conflict than its cause" (King and Melvin 2000, 137). Heated interstate disputes over the status of kin minorities are part of normal politics not only in Eastern Europe but in many other parts of the world as well. Diplomatic friction between the kin state and the country of residence of kin minorities occurs even in the absence of kin citizenship. While kin-state support may radicalise kin-minority demands (Jenne 2007; Wolff 2003), externally supported claim-making does not necessarily lead to any kind of violent conflict as states are rational actors and thus are unlikely to support kin minorities if doing so would be contrary to their own interests (Saideman and Ayres 2012). The only case so far in which non-resident citizenship can be associated with severe interstate tension - that is, armed conflict and territorial adjustments - is the 2008 Russian intervention in the South Ossetian territories in Georgia. However, again, the Ossetian external citizens whom Russia allegedly aimed to protect were not ethnic Russians. Moreover, the 2014 annexation of Crimea as well as the secessionist war in Eastern Ukraine show that Russia does not need the pretext of protecting its external citizens in order to violate the territorial integrity of a neighbouring country. Russia occupied and annexed by military force the Crimea, claiming that it had a duty to protect ethnic Russians regardless of whether they have citizenship in Russia or not - most of them were naturalised by Russia after the annexation of Crimea.

The expansion of citizenship beyond the borders may, indeed, be associated with irredentism or even be a catalyst of transborder nationalism in some cases. In 2020, Russia offered fast-track citizenship for residents of Ukraine and Belarus, with obvious geopolitical aims that may extend from exerting pressure on its neighbours to preparing annexation or an intervention similar to the 2008 attack on Georgia (Ganohariti 2020; Klimkin and Umland 2020). Nevertheless, irredentist politics may well be intense even in the absence of kin citizenship and, conversely, extraterritorial citizenship offered for kin minorities may not necessarily intensify the appeal of irredentist claims. Eventually, non-resident citizenship may also reduce internal political pressure, even if kin citizenship is issued with normatively problematic geopolitical intentions. As I explained above, Macedonian politicians have good reasons to be concerned about the increasing number of Bulgarian dual citizens in the country. However, at the same time, many Macedonians without jobs have the opportunity for employment in the EU through Bulgarian passports (Koneska 2015) issued with the intention of delegitimising the Macedonian state. Despite the inevitably provocative intentions of Bulgaria, the implications of transborder citizenship may well be far less frightening, since the individual targets of kin citizenship can use foreign passports for very different purposes than the kin state hoped.

We should not exaggerate the potential threat of all the saber-rattling and other political stunts in relation to kin citizenship. For example, in 2011, Konstantin Zatulin, Chairman of the Duma's committee overseeing Russia's relations with external Russian 
citizens, suggested that the Kremlin would consider offering fast-track citizenship for Kosovo Serbs in the name of Panslavic solidarity (Zatulin 2011) after more than 21,000 (Krasniqi 2011; RT International 2011a) - according to other sources, 50,000 (Moscow Times 2011) - Serbs petitioned the Russian Embassy in Belgrade. Ljubisa Vucic, president of the Association of Citizens from Kosovo and Metohija, claimed that Russian citizenship would guarantee the security of Kosovo Serbs as "Russia is a friendly country that is constitutionally obligated to protect its citizens wherever they are" (Barlovac 2011a). Zatulin argued for extending citizenship to Kosovo Serbs by noting that Russians and Serbs are connected by their religious traditions and joint battles against the Ottoman Empire. He added that, through granting kin citizenship for Serbs in Kosovo, Russia could prevent the Western integration of Kosovo. Gennady Zyuganov, leader of the Communist Party of the Russian Federation, responded that he would support the proposal of the Kosovo Serbs and Foreign Minister Sergey Lavrov promised that the Kremlin would give thorough consideration to the request of the Kosovo Serbs (Barlovac 2011b). In the end, the Russian government backed off and promised humanitarian aid only, rather than citizenship for ethnic Serbs in Kosovo (RT International 2011b). Taken together, the past 25 years show that Eastern European kin states are rational actors who, despite their often loud fire-brand transborder rhetoric, rarely engage in costly and risky interstate conflicts in defence of the transborder nation (King and Melvin 2000).

\section{Conclusion}

This chapter has offered an overview of non-resident citizenship in post-communist Europe. I have shown that, after the break-up of Yugoslavia and the Soviet Union, new and restored states used citizenship policies for the purpose of ethnic engineering. Through denying membership to resident minorities and the parallel inclusion of non-resident co-ethnics, the governments of the successor states of multinational federations wanted to secure the political dominance of the core ethnic groups which, in many cases, formed only in a slim majority. These preferential citizenship and quasi-citizenship policies were in line with the rhetoric of most post-communist Eastern European states, where mainstream parties framed democratic transition and independence as a nation-building project. In some cases, the kinship-based preferential treatment of non-resident kin minorities served geopolitical purposes. In others, non-resident ethnic kin were offered membership that included voting rights as part of a special gerrymandering project - the inclusion and enfranchisement of non-resident populations changed electoral balances.

I have also shown that kin citizenship is often the source of diplomatic disputes and interstate friction. In extreme cases, claims over non-resident citizens may even lead to armed conflict, as the 2008 Russian invasion of South Ossetian territories in Georgia showed. In other cases, however, non-resident citizenship and the kin state's transborder 
engagement in support of their kin minorities did not result in violent conflict. Disputes over non-resident citizenship rarely goes beyond minor diplomatic friction and violent conflict may occur even in the absence of kin citizenship. Despite their frequently harsh rhetoric, even nationalising Eastern European state actors do not often risk their rational interests for the sake of helping their transborder kin groups. If they do get involved in interstate conflict over them, they may do so without the pretence of fulfilling their duties as protecting powers for their citizens abroad.

\section{References}

Barlovac, B. 2011a. Kosovo Serbs seek safety in Russian citizenship, Balkan Insight, 15 November. Available at: http://www.balkaninsight.com/en/article/kosovo-serbs-request-russian-passports (accessed 23 November 2020).

Barlovac, B. 2011b. Kosovo Serbs urged to emigrate to Russia, Balkan Insight, 17 November. Available at: http://www.balkaninsight.com/en/article/russia-reviews-kosovo-serbs-request-for-citizenship (accessed 23 November 2020).

Băsescu, T. 2016. Romania is obliged to unite with the Republic of Moldova, News Moldova, Video, News, Online News | National Public Broadcaster "Teleradio-Moldova."

Bauböck, R. 2007. Stakeholder citizenship and transnational political participation: a normative evaluation of external voting, Fordham Law Review, 75(5): 2393-2447.

$B B C$ News 2014. Moldova's Trans-Dniester region pleads to join Russia, BBC News, 18 March. Available at: http://www.bbc.com/news/world-europe-26627236 (accessed 24 November 2020).

Billig, Michael. 1995. Banal Nationalism. London: Sage.

Bird, M. 2015. A union between Moldova and Romania: on the cards? EUobserver, 05 March. Available at: https://euobserver.com/beyond-brussels/127824 (accessed 23 November 2020).

Brubaker, R. 1992. Citizenship and Nationhood in France and Germany. Cambridge, MA: Harvard University Press.

Brubaker, R. 1998. Myths and misconceptions in the study of nationalism, in Moore, M. (ed.) National Self-Determination and Secession. Oxford: Oxford University Press, 233-260.

Brubaker, R. 2011. Nationalizing states revisited: projects and processes of nationalization in post-Soviet states, Ethnic and Racial Studies, 34(11): 1785-1814. https://doi.org/ 10.1080/01419870.2011.579137.

Bunce, V. 1995. Should transitologists be grounded? Slavic Review, 54(1):111-127. https:// doi.org/10.2307/2501122

Chiriac, M. 2016. Romanian ex-president seeks Moldovan citizenship, Balkan Insight, 21 March. Available at: http://www.balkaninsight.com/en/article/former-romanian-president-seeks-moldovan-citizenship-03-20-2016 (accessed 24 November 2020). 
Džankić, J. 2010. Montenegro signs the European Convention on Nationality but rejects dual citizenship, EUDO Citizenship News, 26 May. Available at: https://globalcit.eu/ montenegro-signs-the-european-convention-on-nationality-but-rejects-dual-citizenship/ (accessed 24 November 2020).

Džankić, J. 2012. Country Report: Montenegro. Florence: Robert Schuman Centre for Advanced Studies, EUDO Citizenship Observatory .

Džankić, J. 2015. Resistance to extraterritorial citizenship, in Agarin, T. and Paweł Karolewski, I. (eds) Extraterritorial Citizenship in Postcommunist Europe. London: Rowman and Littlefield International, 177-196.

Elster, J. 1991. Constitutionalism in Eastern Europe: an introduction, University of Chicago Law Review, 58(2): 447-482.

EurActiv.Com 2009. Romania offers citizenship to Moldovans, EurActiv.Com, 15 April. Available at: http://www.euractiv.com/section/justice-home-affairs/news/romania-offers-citizenship-to-moldovans/ (accessed 24 November 2020).

Euronews 2014. Transnistrian leader Shevchuk says he wants a "civilised divorce" with Moldova, Euronews, 07 June. Available at: http://www.euronews.com/2014/06/07/ interview-transnistran-president-shevchuk-says-he-wants-a-civilised-divorce-/ (accessed 25 November 2020).

Ganohariti, R. 2020. Between politics and geo-politics: Russia amends its citizenship law. Globalcit, 28 April. Available at: https://globalcit.eu/between-politics-and-geo-politics-russia-amends-its-citizenship-law/ (accessed 24 November 2020).

Gasca, V. 2012. Country Report: Moldova. Florence: Robert Schuman Centre for Advanced Studies, EUDO Citizenship Observatory.

Gellner, E. 1983. Nations and Nationalism. New Perspectives on the Past. Ithaca: Cornell University Press.

Hristova, M. 2010. Bulgarian passports for Macedonians: debunking myths, Novinite Insider, 04 February. Available at: http://www.novinite.com/articles/112811/Bulgarian+Passports+for+Macedonians\%3A+Debunking+Myths (accessed 24 November 2020).

Iordachi, C. 2004. Dual citizenship and policies toward kin minorities in Central Eastern Europe, in Kántor, Z., Majtényi, B., Vízi, B. and Halász, I. (eds) The Hungarian Status Law: Nation Building and/or Minority Protection. Sapporo: Hokkaido University, Slavic Eurasian Studies, 239-269.

Jarve, P. and Poleshchuk, V. 2013. Country Report: Estonia. Florence: Robert Schuman Centre for Advanced Studies, EUDO Citizenship Observatory.

Jenne, E.K. 2007. Ethnic Bargaining: The Paradox of Minority Empowerment. New York: Cornell University Press.

Jileva, E. and Smilov, D. 2013. Country Report: Bulgaria. Florence: Robert Schuman Centre for Advanced Studies, EUDO Citizenship Observatory.

King, C. and Melvin, N.J. 2000. Diaspora politics: ethnic linkages, foreign policy, and security in Eurasia, International Security, 24(3): 108-138. Available at: https://www. 
mitpressjournals.org/doi/10.1162/016228899560257?mobileUi=0\& (accessed 24 November 2020).

Kissane, B. and Sitter, N. 2010. National identity and constitutionalism in Europe: introduction, Nations and Nationalism, 16(1): 1-5. https://doi.org/10.1111/j.14698129.2010.00431.x

Klimkin, P. and Umland, A. 2020. Russlands begehrliche Fürsorge bedroht die Nachbarrepubliken, Neue Zürcher Zeitung, 09 September. Available at: https://www.nzz.ch/meinung/russlands-begehrliche-fuersorge-bedroht-die-nachbarrepubliken-Id.1572148 (accessed 25 November 2020).

Kolsto, P. 2014. Transnistria is a bridge too far for Russia, OpenDemocracy, 11 June. Available at: http://www.opendemocracy.net/od-russia/p\%C3\%A5I-kolst\%C3\%B8/ transnistria-is-bridge-too-far-for-russia (accessed 24 November 2020).

Koneska, C. 2015. Ethnic identity, domestic politics, and EU incentives, in Agarin, T. and Paweł Karolewski, I. (eds) Extraterritorial Citizenship in Postcommunist Europe. London: Rowman and Littlefield International, 155-176.

Koska, V., Ragazzi, F. and Stiks, I. 2013. Country Report: Croatia. Florence: Robert Schuman Centre for Advanced Studies, EUDO Citizenship Observatory.

Krasniqi, G. 2011. Whose citizens? Kosovan Serbs between Kosovo, Serbia and Russia, EUDO Citizenship News, 09 September. https://globalcit.eu/?s=Whose+citizens (accessed 24 November 2020).

Kruma, K. 2010. Latvian integration policy: lost in translation, in van Oers, R., Ersbøll, E. and Kostakopoulou, D. (eds) A Re-Definition of Belonging? Language and Integration Tests in Europe. Leiden: Martinus Nijhoff, 241-270.

Kymlicka, W. 2004. Justice and security in the accommodation of minority nationalism, in May, S., Modood, T. and Squires, J. (eds) Ethnicity, Nationalism, and Minority Rights. Cambridge: Cambridge University Press, 144-175. https://doi.org/10.1017/ CBO9780511489235.008.

Kymlicka, W. 2007. Multicultural Odysseys: Navigating the New International Politics of Diversity. Oxford and New York: Oxford University Press.

Liebich, A. 2009. Altneuländer or the vicissitudes of citizenship in the new EU states, in Bauböck, R., Perchinig, B. and Sievers, W. (eds) Citizenship Policies in the New Europe. Amsterdam: Amsterdam University Press, 21-44.

Medved, F. 2013. Country Report: Slovenia. Florence: Robert Schuman Centre for Advanced Studies, EUDO Citizenship Observatory.

Mihalache, M. 2015. Sondaj INSCOP: Două treimi dintre Români vor marea unire cu Republica Moldova până în 2018, Adevarul.Ro, 31 July. Available at: http://adevarul.ro/news/ politica/doua-treimi-romani-vor-marea-unire-republica-moldova-2018-1_55ba236df5eaafab2c1877c0/index.html (accessed 24 November 2020).

Moscow Times 2011. Kosovo Serbs want Russian citizenship, The Moscow Times, 27 November. Available at: http://www.themoscowtimes.com/article/448714.html (accessed 24 November 2020). 
Mühlfried, F. 2010. Citizenship at war: passports and nationality in the 2008 Russian-Georgian conflict, Anthropology Today, 26(2): 8-13.

Özgür Baklacıoğlu, N. 2004. Dual citizenship, extraterritorial elections and national policies: Turkish dual citizens in the Bulgarian-Turkish political sphere, in Kántor, Z., Majtényi, B., Vízi, B. and Halász, I. (eds) The Hungarian Status Law: Nation Building and/or Minority Protection. Sapporo: Hokkaido University, Slavic Eurasian Studies, 319-358.

Pettai, V. and Hallik, K. 2002. Understanding processes of ethnic control: segmentation, dependency and co-optation in post-communist Estonia, Nations and Nationalism, 8(4): 505-529.

Pogonyi, S. 2011. Dual citizenship and sovereignty, Nationalities Papers, 39(5): 685-704. https://doi.org/10.1080/00905992.2011.599377

Pogonyi, S. 2017. Extra-Territorial Ethnic Politics, Discourses and Identities in Hungary. Cham: Palgrave Macmillan.

Přibáň, J. 2004. Reconstituting paradise lost: temporality, civility, and ethnicity in post-communist constitution-making, Law Society Review, 38(3): 407-432. https:// doi.org/10.1111/j.0023-9216.2004.00052.x.

Radović, M. 2013. Citizenship and Religion in the Post-Yugoslav States. Edinburgh: Social Science Research Network, CITSEE Working Paper No. 2013/35.

Rava, N. 2013. Country Report: Serbia. Florence: Robert Schuman Centre for Advanced Studies, EUDO Citizenship Observatory.

RT International 2011a. Kosovo Serbs turn to Russia for protection, RT International 14 November. Available at: https://www.rt.com/politics/kosovo-serbs-russian-citizenship-253/ (accessed 24 November 2020).

RT International 2011 b. Aid for Kosovan Serb minority but no Russian passports, RT International, 01 December. Available at: https://www.rt.com/politics/russia-pledges-kosovo-citizenship-767/ (accessed 23 November 2020).

Saideman, S.M. and Ayres, R.W. 2012. For Kin or Country: Xenophobia, Nationalism, and War. New York: Columbia University Press.

Simon, T. 2013. Citizenship as a weapon, Citizenship Studies, 17(3-4): 505-524.

Shachar, A. 2009. The Birthright Lottery: Citizenship and Global Inequality. Cambridge, MA: Harvard University Press.

Skulte-Ouaiss, J. 2015. Less is more, or more is less, in Agarin, T. and Paweł Karolewski, I. (eds) Extraterritorial Citizenship in Postcommunist Europe. London: Rowman and Littlefield International, 88-109.

Snyder, J.L. 2000. From Voting to Violence: Democratization and Nationalist Conflict. New York: W.W. Norton.

Smith, D.J. 2003. "The devil and the deep blue sea": European integration, national identity and foreign policy in post-communist Estonia, Journal of Communist Studies and Transition Politics, 19(3): 156-177. 
Stiks, I. 2010. A Laboratory of Citizenship: Shifting Conceptions of Citizenship in Yugoslavia and Its Successor States. Social Science Research Network, CITSEE Working Paper No. 2010/02.

Summers, J. 2014. Peoples and International Law. Leiden: Martinus Nijhoff.

Todorova, M. 2015. Is there weak nationalism and is it a useful category? Nations and Nationalism, 21(4): 681-699.

Traunmüller, K. and Agarin, T. 2015. Regulating access to citizenship after territorial changes, in Agarin, T. and Paweł Karolewski, I. (eds) Extraterritorial Citizenship in Postcommunist Europe. London: Rowman and Littlefield International, 43-63.

Verdery, K. 1998. Transnationalism, nationalism, citizenship, and property: Eastern Europe since 1989, American Ethnologist, 25(2): 291-306.

Vlas, C. 2016. Romania ex-President Traian Băsescu and his wife requested Moldovan citizenship, Moldova.Org, 19 March. Available at: http://www.moldova.org/en/romania-ex-president-traiain-basescu-wife-requested-moldovan-citizenship/ (accessed 25 November 2020).

Wolff, S. 2003. Disputed Territories: The Transnational Dynamics of Ethnic Conflict Settlement. London: Berghahn.

Zatulin, K. 2011. Лучшее, Что Можно Сделать, - Незамедлительно Принять Просьбы 21 Тыс. Сербов о Российском Гражданстве, Известия, 24 November. Available at: http://izvestia.ru/news/507736 (accessed 25 November 2020).

Zelev, I. 2008. Russia's policy toward compatriots in the former Soviet Union, Russia in Global Affairs, 6(1): 49-62. 


\title{
Chapter 8
}

\section{The Danish Turn Towards Dual Citizenship}

Eva Ersbøll, Senior Researcher Emerita, The Danish Institute for Human Rights

\begin{abstract}
This chapter gives an account of the Danish turn towards dual citizenship, which began after the start of the new millennium and ended in December 2014 with the adoption of an act on dual-citizenship acceptance that entered into force on 01 September 2015. The chapter examines the Danish path towards dual citizenship from a legal and political perspective and argues that the idea of dual-citizenship acceptance matured gradually in the context of international and Nordic interdependence. Thus, the Danish approach resembles that of most other countries. I argue that the Danish slowness in terms of dual-citizenship acceptance is not a reflection of a Danish particularity but, rather, reflects an extraordinary political constellation in the Danish parliament during the first decade of the new millennium. Hereby, I dissociate myself from claims in the comparative literature that the opportunity to strip Danish dual citizens of their Danish citizenship was a key argument for Denmark's turn towards dual citizenship.
\end{abstract}

\section{Introduction}

Today, most of the world's countries have accepted dual citizenship defined as the simultaneous possession of two or more citizenships (multiple or plural citizenship) by the same person. ${ }^{1}$ Relatively late, in 2015 , Denmark joined the company of accepting states. This chapter gives an account of the Danish turn towards dual citizenship, arguing that, despite its lateness, the Danish acceptance of it did not come as a surprise, as elsewhere argued (Midtbøen 2019, 299). Instead, the idea of accepting dual citizenship matured gradually in the context of international interdependence, as has been the case in most other countries (Vink et al. 2019).

Insofar as the Danish tardiness has been seen as an expression of a Danish particularity, the swiftness of response of the other Nordic countries has often been the standard of reference. I maintain that there are good reasons to assume that Denmark's acceptance of dual citizenship more than a decade after its acceptance in Sweden, Finland and Iceland is not an expression of Danish particularity. Rather, the policy on dual citizenship may be explained by who has had the political majority at a given time and in a given place

1 See the European Convention on Nationality (1997) article 2(b). 
(Joppke 2003). Arguably, the prolonged Danish turn towards dual citizenship reflects the extraordinary political constellation in the Danish parliament within the crucial period after the turn of the new millennium.

This chapter outlines the process of the Danish turn toward dual citizenship to explore the validity of this hypothesis. It starts with a quick look back at the historical development of Danish citizenship law and the influential external factors. Thereafter, it gives a brief overview of the content of the Danish act on the acceptance of dual citizenship and evaluates the country's dual-citizenship acceptance in the light of the phenomenon of immigrant integration and securitisation. The chapter concludes with some general observations.

\section{Danish citizenship in a historical perspective}

In 1776, the Danish King promulgated the act "Indføds-Retten" (ius indigenatus), which reserved all public positions in His Majesty's Kingdom exclusively to native-born subjects and those who were considered to be their equal. Effectively, the act was not a citizenship law - at least not in the current sense of the term - but it still had many of the characteristics of a citizenship law. During the latter part of the nineteenth century, the 1776 act interacted with the first Danish Constitution of 1849, which used and uses the concept "indfødsret" as one of citizenship. Among other things, the constitution made indfødsret a condition for the acquisition of electoral rights at parliamentary elections.

According to the constitution, foreigners could only acquire indfødsret by statute. This is still the case; cf. the present Danish constitution's section 44, which lays out the responsibility for the unique Danish system according to which naturalisation is granted by the legislature. Around the mid-nineteenth century, Denmark became a country of emigration. Factors such as a growing population, poverty, low incomes, high prices for land, unemployment and better possibilities for transportation made many - especially young - Danes emigrate overseas, first and foremost to America. At that time, the concept of indfødsret had become the legal expression of being "Danish"; however, Denmark had not adopted any provision on the renunciation or loss of indfødsret. In an age of emigration, this legal situation became impractical, since foreign states, among which the United States, often required the renunciation of all legal connections with immigrants' countries of origin as a condition for naturalisation (Spiro 2016, 27-29). Denmark could, in such a situation, release the country's emigrants from their status as Danish subjects; this, however, would not imply a loss of Danish indfødsret.

To solve the problem, in 1871 Denmark adopted an act on the loss of indfødsret ${ }^{2}$ and, in 1872 , concluded a convention with the United States on the avoidance of dual

2 Act No. 54 of 25 March 1871 including an Addition to the Act on Indfødsret of 15 January 1776. 
citizenship (the Bancroft Convention). According to this latter, Danish subjects who naturalised within the US should be held by Denmark to be citizens of the US; reciprocally, citizens of the US who naturalised in Denmark should be held by the US to be Danish subjects. The two countries could readmit their former citizens/subjects and allow them to become their citizens/subjects again. In such cases, the other country should refrain from claiming these persons as its citizens (based on their former naturalisation). ${ }^{3}$ From 1886-1889, the concrete naturalisation acts made it explicit that the renunciation of a foreign citizenship was a condition for the acquisition of Danish citizenship.

In 1898, Denmark adopted its first genuine citizenship act, which introduced ius sanguinis as its principle of fundamental acquisition while maintaining the ius soli principle by establishing that a person born and brought up in Denmark automatically acquired Danish indfødsret, ex lege, at the age of 19.

In general, the rejection of dual citizenship infused the act's provisions on the acquisition and loss of citizenship. A child born in wedlock acquired Danish citizenship if the father was a Danish citizen; a child born out of wedlock acquired Danish citizenship if the mother was a Danish citizen. Due to the husband's principal status, a foreign woman acquired the husband's Danish citizenship by marriage, as did the couple's children (a foreign woman would normally lose her citizenship of origin on marriage). Moreover, when a man acquired Danish citizenship through naturalisation, this would normally also comprise his wife and children. Conversely, a Danish citizen who acquired foreign citizenship would lose his or her Danish citizenship; if a husband's foreign citizenship were extended to his wife and children, then they would normally lose their Danish citizenship.

In principle, the Danish citizenship act of 1925 was - with minor changes - based upon the 1898 act's provisions on the acquisition of citizenship. ${ }^{4}$ However, as a novelty, the 1925 act provided for the loss of Danish citizenship due to birth and residence abroad. As a rule, a Danish man and an unmarried Danish woman who were born abroad and had never resided or stayed in Denmark under circumstances that indicated some association with the country would lose their Danish citizenship upon attaining the age of 22. If a married man lost his citizenship in this way, the loss would include his wife and any children born to the marriage. The same applied to an unmarried woman and her children. Amendments to this provision, in 1968 and 1998, prevent such a loss if the target person and/or his or her children would thereby become stateless.

The existing 1950 act introduced the principle of gender equality and, consequently, a Danish woman would no longer lose her citizenship by marrying a foreigner. Still, due to the disfavour of dual citizenship, the 1950 act did not give a Danish married woman

3 See Patent No. 25 of 18 March 1873 concerning the convention of 20 July 1872 on Danish subjects naturalised in the US and American citizens naturalised in Denmark.

4 Act No. 123 of 18 April 1925 on Acquisition and Loss of Nationality, replacing Act No. 42 of 19 March 1898 on Acquisition and Loss of Nationality. 
the right to pass her citizenship on to her children. ${ }^{5}$ Hitherto, the acquisition of a foreign citizenship had led to the loss of Danish citizenship, regardless of whether the acquisition was voluntary or involuntary. According to the $1950 \mathrm{act}$, which ended this principle, Danish citizenship was automatically lost if

- a person acquired foreign citizenship upon application or with his or her express consent;

- a person acquired foreign citizenship by entering the public service of another country; or

- an unmarried child under 18 years of age became a foreign citizen by the fact that either parent holding or sharing custody of the child acquired foreign citizenship (unless the other parent retained Danish citizenship and shared custody of the child).

Moreover, the 1950 act changed the earlier rule on immigrant descendants' entitlement to Danish citizenship, making the right dependent on a declaration to that effect between the ages of 21 and 23. A person who was stateless or who would lose his or her foreign citizenship by the acquisition of Danish citizenship could make such a declaration after having attained the age of 18 .

An amendment of 1968 changed the declaration rule in such a way that birth on Danish territory was no longer a requirement for the acquisition of Danish citizenship. Instead, the second and the so-called 1.5 generation ${ }^{6}$ could acquire citizenship by declaration between the ages of 21 and 23 years, insofar as they had lived in Denmark for at least five years before the age of 16 and permanently between the ages of 16 and 21. The rule also applied to persons aged 18 who had lived in Denmark permanently for the previous five years and prior to that for a total of at least five years if they were stateless or would automatically lose their foreign citizenship because of the acquisition of Danish citizenship.

In 1972, Denmark ratified the 1963 European Convention on the reduction of cases of multiple nationality and military obligations in cases of multiple nationality. However, shortly after this, the elimination of discrimination against women became a priority, ${ }^{7}$ which led to a greater toleration of dual citizenship. Consequently, the Danish citizenship act was amended in 1978 in such a way that children born in wedlock acquired Danish citizenship at birth if either the mother or the father were a Danish citizen. The change allowed children born in mixed marriages to acquire dual citizenship at birth.

5 As an exception, a married woman could pass her citizenship on to the children in cases where the husband was a stateless person or where the child would not acquire the citizenship of the father at birth.

6 Those born abroad who enter a host country while still minors.

7 See also the Convention on the Elimination of all Forms of Discrimination against Women (1979). 


\section{The increasing tolerance of dual citizenship}

In the 1980s, a broader acceptance of dual citizenship developed due, among other things, to intensified movements across borders. Settled immigrants and their descendants needed to complete their integration through acquisition of the host state's citizenship. Therefore, many European states had come to favour a more liberal approach to dual citizenship. Several states, among others Sweden, requested the Council of Europe's Committee on Legal Cooperation (CDCJ) to consider a less restrictive attitude towards it. ${ }^{8}$ Consequently, the Council of Europe asked a Committee of Experts on Multiple Nationality (CJ-PL) to examine the question of dual-citizenship tolerance. As a result, in 1993, the Council of Europe adopted a second protocol to the 1963 convention that allowed dual or multiple citizenship in more cases. ${ }^{9}$

The member states agreed during the Expert Committee's work on the protocol that the committee should prepare a new convention dealing more generally with matters relating to nationality. ${ }^{10}$ The Expert Committee and a working group took on the task and eventually, in 1997, the Council of Europe adopted the European Convention on Nationality, which recognised that each state was free to decide which consequences it attached in its internal law to a citizen's acquisition and/or possession of another citizenship. ${ }^{11}$ Nevertheless, in several specified cases, the convention demanded that state parties accept dual citizenship.

On 06 November 1997, 15 states, among which the Nordic states, signed the European Convention on Nationality (ECN). Hitherto, the Nordic states had cooperated on citizenship matters and, until the late 1970s, their citizenship laws had been almost identical. However, to comply with the ECN, all the Nordic countries needed to adopt amendments. Finland, Norway and Sweden took the opportunity to thoroughly reform their laws, while Iceland and Denmark limited themselves to amending their existing citizenship acts. Already, at the beginning of the 1990s, Finland had started discussions on a new citizenship act, largely evolving around the issue of multiple citizenship. Formally, however, the reform preparations began in 1997 (Fagerlund and Brander 2013). ${ }^{12}$ Almost at the same time, the Swedish government assigned to a parliamentary committee the task of reviewing the Swedish citizenship act and, by a supplementary directive, the task

8 See Slutbetänkande av 1997 års medborgarskapskommitté (SOU) 1999:34, p. 164. For development in Sweden, see Spång (2007, 103ff).

9 The second protocol amending the 1963 convention opened to signature on 02 February 1993. Available at: https://www.coe.int/en/web/conventions/full-list/-/conventions/rms/ 090000168007 bf4c (accessed 26 November 2020).

10 See, among other things, the interim report of the Committee of Experts on Multiple Nationality (CJ-PL) on Matters relating to Nationality DCCJ (93) 1 and CJ-PL (93) 11.

11 See the preamble of the European Convention on Nationality (1997).

12 See also the Finnish government proposition RP 235/2002. 
of investigating, without any preconditions, the issue of dual citizenship. ${ }^{13}$ In February 1999, Norway followed suit and assigned to a Norwegian Expert Committee the task of preparing a Norwegian citizenship law reform, among other things, by investigating the question of dual citizenship. ${ }^{14}$ In 1998, Denmark, which did not embark on such ambitious reform preparations, became the first Nordic country to amend its citizenship legislation in a way that allowed the ratification of the ECN. ${ }^{15}$

The bill that should pave the way for Denmark's ratification of the ECN did not suggest amendments that deviated from Denmark's obligations according to the 1963 convention. ${ }^{16}$ Already beforehand, the Danish legislation complied with the ECN's minimum requirements for dual-citizenship acceptance ${ }^{17}$ and there were other signs that the Danish approach towards dual citizenship had become more tolerant. Firstly, the 1998 act repealed a provision on the possible loss of Danish citizenship based on interstate agreements that applied to Danes born and raised abroad. Secondly, the act softened the residence requirements for immigrant descendants' entitlement to Danish citizenship although this would imply more dual citizens. ${ }^{18}$ The explanatory notes to the bill referred to the European trend towards greater acceptance of dual citizenship and the fact that this status no longer caused so many concerns.

Still, Denmark did not (yet) fully embrace dual citizenship. In this respect, Sweden became the pioneer among the Nordic states. ${ }^{19}$ In 2001, the Swedish citizenship reform on full dual-citizenship acceptance entered into force. Finland and Iceland followed suit

13 SOU:34 Svenskt medborgarskap, Slutbetänkande av 1997 års medborgarskapskommitté.

14 See NOU Norges offentlige utredninger 2000: 32: Lov om erhverv og tap av norsk statsborgerskap, at: https://www.regjeringen.no/contentassets/7f010dcc7b77416c81368385374ae5c3/ no/pdfa/nou200020000032000dddpdfa.pdf.

15 Act no. 1018 of 23 December 1998 on the amendment to the Danish citizenship act (Ratification of the ECN, etc.).

16 Bill L 69, FT 1998-99, at: https://www.folketingstidende.dk/samling/19981/lovforslag/L69/index. htm.

17 Cf. note of 07 April 1998 on dual citizenship from the Ministry of Justice to the Parliamentary Naturalisation Committee (The Naturalisation Committee annex 22). The note that was prepared for the committee's discussions of the renunciation requirement in naturalisation cases stated that, where an applicant was granted asylum or where renunciation or loss were not possible or could not reasonably be required, Denmark did not make renunciation or loss of another citizenship a condition for naturalisation. The other Nordic states followed a similar practice (except Iceland, which generally did not require renunciation of a former citizenship in naturalisation cases).

18 By the amendment, young persons who were brought up in Denmark were entitled to Danish citizenship by declaration from the age of 18 although they might not lose their foreign citizenship at such a young age (so far, the minimum age limit had been 21 ). The note concluded that, generally, there was a tendency towards citizenship toleration and that only a few countries, like Germany, still maintained the principle of avoiding dual citizenship as far as possible.

19 See SOU:34 Svenskt medborgarskap, Slutbetänkande av 1997 års medborgarskapskommitté. 
in 2003, while a similar change in Norway did not materialise - although, in 2000, a majority among the Norwegian citizenship committee's members had recommended full acceptance of dual citizenship. ${ }^{20}$

Arguably, for Denmark - in terms of dual-citizenship acceptance - 2001 became a decisive year. That year, the country held a general election and a Liberal-Conservative government replaced the former Social Democrat-led government. This Liberal-Conservative government stayed in office for four terms, from 2001-2011, with support from the Danish People's Party, which totally opposed dual citizenship. The Danish Prime Minister, who took office in 2001, had developed a so-called "contract policy", according to which any necessary reforms of the social welfare system, etc. had to be announced before an election and to be carried out afterwards - as contracted by the electorate (Lidegaard 2014). Thus, it became of the utmost importance for the government to fulfil its promises to the voters. This proved possible with the support of the Danish People's Party, which had the number of seats needed to secure a majority vote in parliament and the willingness to cooperate in return for concessions, especially regarding the restrictions of the aliens and citizenship legislation. ${ }^{21}$

Regarding citizenship legislation, another important event was the election of two charismatic pastors - Krarup and Langballe - who had a national-conservative approach and a particular interest in citizenship matters as Members of Parliament and prominent members of the Parliamentary Naturalisation Committee. Both represented the Danish People's Party and both had long been members of the theological movement Tidehverv, which espouses a strict, conservative Lutheranism and rejects humanism and human rights (international conventions). According to them, the meaning of being a national is to be born in a given place within a given people and in a given historical context. To quote one of them, the writer Søren Krarup (1987, cited in and translated by Haugen 2011, 482): "We are created by God, and to creation belongs earthliness, history and hence nationality: to be born in a particular country and people". Thus, to them, dual citizenship was an absurdity.

Arguably, this make-up of the Danish parliament during the first decade of the new millennium may in part explain why Denmark needed more time before decisively turning towards dual citizenship. The next section further explores this hypothesis.

\section{Idling at the crossroads}

As mentioned, Denmark applies a unique naturalisation arrangement according to which the legislature has the naturalisation power and a majority in parliament agrees upon the

20 Norway accepted dual citizenship in 2018; see below in Section 10.

21 For more about the Danish People's Party see https://vbn.aau.dk/ws/portalfiles/portal/ 14109015/widfeldt___FINAL.pdf. 
naturalisation criteria. The political composition in parliament during the first decade of the new millennium made it possible for the Liberal-Conservative government to rule exclusively with the support of the Danish People's Party. In 2002, 2005 and 2008, the two governing parties and the Danish People's Party agreed upon new and continually more restrictive naturalisation criteria.

In addition, in 2005 and 2008, the three parties agreed to initiate a study on the possibilities of adjusting the naturalisation practice with a view to limiting cases of dual citizenship. ${ }^{22}$ They assigned to the Ministry for Integration the task of preparing a draft report on the rules for dual citizenship in Denmark, other countries and international law, which would be presented to the Minister for Integration and the agreement parties. ${ }^{23}$ The Liberal-Conservative government could have no doubt that a turn towards dual-citizenship acceptance might jeopardise its naturalisation agreements with the Danish People's Party and, even worse, might have immeasurable consequences for the government's general ability to find majority support for its policies in parliament. ${ }^{24}$ Even so, during the period from 2001 to 2011, the Danish parliament discussed dual-citizenship toleration several times. Private persons, expat organisations and opposition parties called for such a debate, as did legislative initiatives in other Nordic countries.

In 2002, the government presented a bill in parliament to amend, among other things, the citizenship act's provision on Nordic citizens' acquisition of Danish citizenship by declaration. Thus far, this provision had not included a renunciation demand, since all Nordic states had provided for the automatic loss of citizenship by voluntary acquisition of a foreign citizenship. However, since Sweden had repealed such an automatic loss in 2001, Swedish citizens might become dual Danish-Swedish citizens by declaration if Denmark did not amend its declaration rule. Because this would be against the premise behind the rule, Denmark had to make a change. ${ }^{25}$ The aim of the Danish 2002 bill was to "neutralise" the effects of Sweden's acceptance of dual citizenship by introducing a renunciation requirement. ${ }^{26}$ Therefore, the proposed amendment did not raise much controversy. As explained by the spokesperson for the Social Liberals during the first

22 See circular letter no. 9 of 12 January 2006 and circular letter no. 61 of 22 September 2008.

23 See the statements about the draft report in the Statelessness Commission's report of 2011, p. $1835 \mathrm{f}$ at: https://www.justitsministeriet.dk/sites/default/files/media/Pressemeddelelser/ pdf/2015/statsloesekommission_bind_6.pdf.

24 By its compliance with the tightening of the aliens and citizenship law, the government could normally count on the Danish People's Party in, for instance, negotiations on the state budget.

25 Bill No. 160, presented in parliament on 13 March 2002 and accessible here https://www.folketingstidende.dk/samling/20012/lovforslag/L160/index.htm. On 14 January, the Nordic states had changed the Nordic agreement on citizenship in such a way that, henceforth, it was for each country to decide whether it would apply a renunciation requirement as a condition for acquisition of its citizenship; see the Nordic Agreement of 14 January, article 7.

26 lbid. See explanatory notes to the bill. 
reading of the bill, Denmark had ratified the 1963 convention and the logical corollary was to adjust Danish citizenship legislation because of Sweden's acceptance of dual citizenship. Consequently, in May 2002, the Danish parliament adopted the bill unanimously. ${ }^{27}$ Nonetheless, several political parties wanted to seize this opportunity to discuss whether Denmark should also accept dual citizenship, referring to the development in the neighbouring Nordic countries and in Europe more broadly. ${ }^{28}$

In the years that followed, many individuals and civil society organisations, especially emigrant organisations like Danes Worldwide and www.statsborger.dk, approached the Minister for Integration and/or the Naturalisation Committee, arguing in favour of the acceptance of dual citizenship. Some of the political parties in parliament followed suit by presenting motions for parliamentary resolutions on the acceptance of dual citizenship. In April 2008, a new political party - New Alliance - presented a motion for a parliamentary resolution, $B 87$, on the acceptance of dual citizenship. ${ }^{29}$ In this connection, the Naturalisation Committee decided to convene a closed expert hearing with, among others, representatives from Norway and Sweden. During the first parliamentary reading of the motion, most parties expressed a wish for more knowledge on the advantages and disadvantages of changing the "immemorial principle" of the avoidance of dual citizenship. ${ }^{30}$ Several individuals and organisations approached the Parliamentary Naturalisation Committee, which also received a petition on the acceptance of dual citizenship with 9,400 signatures collected by three Danish expat organisations. ${ }^{31}$ After the first reading of Motion B 87, the Naturalisation Committee held the closed parliamentary expert hearing. ${ }^{32}$ However, due to parliament's summer recess, the motion lapsed.

In November 2008, the Social Liberals and the Liberal Alliance presented two new motions on dual-citizenship acceptance to parliament. ${ }^{33}$ Again, several individuals and

27 Bill No. 160, adopted unanimously by parliament on 30 May 2002.

28 Arnfinn H. Midtbøen $(2019,299)$ argues that, during the debate, the Red-Green Alliance was the only party to "vote for an acceptance of dual citizenship". This is not an adequate description, since the debate was about adaptation of the Danish citizenship act triggered by the Swedish citizenship reform.

29 See Motion B 87, FT 2007-08. At: https://www.ft.dk/samling/20072/beslutningsforslag/ b87/20072_b87_som_fremsat.htm.

30 See the first reading of Motion B 87 FT 2007-08. Available at: https://www.ft.dk/samling/20072/ beslutningsforslag/B87/BEH1-63/forhandling.htm.

31 The different approaches are listed here: https://www.ft.dk/samling/20072/beslutningsforslag/ B87/bilag.htm.

32 The hearing included two presentations on dual citizenship from a historical perspective (among others, from this author), followed by presentations from representatives of the Swedish and Norwegian citizenship authorities, based on these countries' preparatory reports and experiences regarding dual citizenship.

33 Motions B 55 and B 56 are accessible at https://www.ft.dk/samling/20081/beslutningsforslag/ b55/index.htm and https://www.ft.dk/samling/20081/beslutningsforslag/b56/index.htm. 
expat organisations supported the requests. ${ }^{34}$ In early 2009, parliament discussed the two new motions collectively and their deliberations resembled former debates. One of the proposers summed up the debate in this way: "Of course I am disappointed by the forbearing of the minister and the grand parties regarding dual citizenship. However, I notice that what has been said is in fact that, yes, we know very well that this will come sooner or later but we prefer it to be later".35

In April 2009, the Ministry of Integration sent its report on dual citizenship to the Naturalisation Committee. ${ }^{36}$ The report included references to the reports from the Swedish and Norwegian committees on, inter alia, the pros and cons of dual-citizenship tolerance. The report pointed out that, for countries which, in principle, did not accept dual citizenship, one of the reasons was that they saw citizenship as an important symbol of allegiance and loyalty to a country and that therefore, in principle, a person could have only one citizenship. Besides, dual citizenship was opposed for practical reasons such as the avoidance of legal conflicts in matters of international private law, criminal law and diplomatic protection and to prevent people from having several sets of rights - for instance voting rights - in more than one country. The committee concluded that "This, however, must be coupled with the experiences of more countries that the potential conflicts may be avoided by international agreements, multi- or bilateral". ${ }^{37}$

Eventually, in May 2009, a majority in parliament, consisting of the Liberals, the Conservatives, the Social Democrats and the Danish People's Party, turned the motions down. In the Naturalisation Committee's report, the majority referred to two points from the ministry's report - namely that the acceptance of dual citizenship might hamper the diplomatic protection of dual Danish citizens abroad and their extradition for prosecution in Denmark. The Danish People's Party stated in an addendum that it follows from the nature of citizenship (ius indigenatus) that the concept's exclusive meaning is the obligatory allegiance to one single country. ${ }^{38}$

34 The Campaign for Dual Citizenship, www.statsborger.dk, presented a report on "Dual Citizenship for Danes" of 13 May 2008, at: https://www.ft.dk/samling/20072/beslutningsforslag/B87/ bilag/5/558531.pdf; Danes Worldwide appeared before the Naturalisation Committee in May 2008, presenting a note of 20 May 2008 and a statement of 26 May 2009. Available at: https:// www.ft.dk/samling/20081/beslutningsforslag/B55/bilag/14/691874/index.htm.

35 See the parliamentary debate during the first reading of the motions: https://www.ft.dk/samling/20081/beslutningsforslag/B55/BEH1-56/forhandling.htm.

36 Report of 24 April 2009 on the rules of dual citizenship in Denmark, in other countries and in international law: https://www.ft.dk/samling/20081/beslutningsforslag/B55/bilag/11/675611/ index.htm.

37 Ibid., see Section 9 summary.

38 See the Naturalisation Committee's report of 14 May 2009: https://www.ft.dk/samling/20081/ beslutningsforslag/B55/bilag/13/691626/index.htm. 
The minority in parliament (the other political parties) argued that the majority's evaluation of the ministry's report was disproportionate, since the report demonstrated that there were far more advantages than disadvantages linked to the acceptance of dual citizenship.

In March 2011, the Social Liberals presented another motion on the acceptance of dual citizenship to parliament with the aim of equalising Danish citizenship legislation with that of other European countries. ${ }^{39}$

In April 2011, the first reading of the new motion took place in parliament and followed, to some extent, the same lines as the earlier parliamentary debates on the acceptance of dual citizenship - except that the Liberals admitted that the development in other countries made it more and more difficult for Denmark to maintain its traditional resistance. ${ }^{40}$ Parliament did not take a final decision on the motion before the summer recess. Thereafter - and following a general election - Denmark reached a distinct turning point in the move towards dual-citizenship acceptance.

\section{Agreement on dual-citizenship acceptance}

The general election took place on 25 August 2011 and eventually, on 3 October 2011, the Social Democratic Party succeeded in establishing a minority government together with the Social Liberals and the Socialist People's Party and with the support of the Red-Green Alliance. The three parties agreed in their government platform of October 2011 - "A Denmark that stands united"41 - that the government would accept dual citizenship. The reason was as follows: "Denmark is a modern society in a globalised world. Therefore, it must be possible to have dual citizenship". In December 2012, the government appointed a cross-ministerial working group to draft a report on dual citizenship, in which they should propose different models for the acceptance of dual citizenship and outline the consequences of the different models. ${ }^{42}$

In May 2013, the Liberal Party announced its commitment to dual-citizenship acceptance. Apparently, the party had some difficulty in explaining its change of mind. In a bungled TV interview, the ex-Prime Minister claimed that the party had changed

39 Motion B 82 (2010-11), at: https://www.ft.dk/samling/20081/beslutningsforslag/B55/bilag/13/ 691626.pdf.

40 The first reading of motion B 82, 2010-11, is available here: https://www.ft.dk/samling/20101/ beslutningsforslag/B82/BEH1-84/forhandling.htm

41 Government platform of October 2011, Et Danmark der står sammen, is accessible here http://www.stm.dk/publikationer/Et_Danmark_der_staar_sammen_11/Regeringsgrundlag_ okt_2011.pdf

42 See the introduction of the Working Group on Dual Citizenship's report of March 2014, at: https://www.justitsministeriet.dk/sites/default/files/media/Pressemeddelelser/pdf/2014/Arbejdsgrupperapport\%20om\%20dobbe 
its position but not its attitude. In this regard, he referred to "the present parliamentary situation". ${ }^{43}$ On Denmark's Constitution Day, 05 June, the ex-Prime Minister admitted that his explanation had been somewhat opaque.

In March 2014, the working group finalised its report on dual citizenship - outlining the following options:

- full acceptance of dual citizenship;

- dual citizenship for emigrants but not for immigrants;

- dual citizenship for citizens from EU member states, EEA countries and Switzerland;

- dual citizenship for Nordic citizens;

- dual citizenship for citizens from member states of NATO; and

- dual citizenship for citizens from countries that have bilateral agreements with Denmark.

The working group stressed that the last two models might raise questions on unlawful discrimination based on nationality. In any case, denunciation of (part of) the 1963 convention, with a period of notice of one year, was obligatory. In a press release of 14 March 2014, the Minister for Justice presented the report, ${ }^{44}$ stressing that it was important for the government to achieve broad parliamentary support for the new rules on dual-citizenship acceptance. ${ }^{45}$

On 04 June 2014, the government announced that it had reached a broad agreement on full acceptance of dual citizenship. Only the Conservatives and the Danish People's Party did not agree. ${ }^{46}$ On this occasion, the Minister for Justice made the following statement:

Legislation on dual citizenship means a lot for many people since it touches upon national identity and attachment. In a globalised world, this means a lot. Many choose to settle in foreign countries while still maintaining a strong connection

43 See the interview on 24 May 2013 on TV2 News, at: https://www.youtube.com/watch?v= yd6S35Pn0sU. See also https://nyheder.tv2.dk/article.php/id-68706188\%3AlÃf/E'Ã, $\hat{A}_{s} k k e-v i-$ har-skiftet-standpunkt-ikke-holdninger.html\%29 As outlined, semantically there is actually a difference between attitude and position.

44 See the Ministry for Justice's press release at: https://www.justitsministeriet.dk/nyt-og-presse/ pressemeddelelser/2014/justitsminister-bred-adgang-til-dobbelt-statsborgerskab.

45 In a newspaper interview on the same day that the Minister for Justice informed on the government's proposal, she mentioned the derived possibility for citizenship revocation, which the Liberal spokesperson on citizenship matters had also spoken of as a "little twist"; see: https://www.berlingske.dk/politik/dobbelt-statsborgerskab-kan-foere-til-flere-udvisningeraf-kriminelle.

46 See the Minister for Justice's announcement of the agreement at: https://www.justitsministeriet. dk/nyt-og-presse/pressemeddelelser/2014/regeringen-indgaar-bred-aftale-om-dobbelt-statsborgerskab. 
to their country of origin. We must not force people to choose among affiliations. Therefore, a broad political majority supports full acceptance of dual citizenship. Such access to dual citizenship will promote the integration of all people from all over the world. ${ }^{47}$

\section{The law-making process}

In October 2014, the Minister for Justice presented a bill in parliament on the full acceptance of dual citizenship, according to which Danes could retain Danish citizenship after having moved abroad and obtained a foreign citizenship and foreigners residing in Denmark could become Danish citizens without a renunciation requirement. Moreover, the bill proposed two transitionary arrangements - one for former Danish citizens who could re-acquire Danish citizenship by declaration within a transitionary period of five years and one for foreigners who could acquire Danish citizenship by declaration within a two-year period if they had been naturalised conditionally and had not yet fulfilled the requirement of being released from their foreign citizenship. The changes were designed to enter into force on 01 September 2015, when the Danish denunciation of the 1963 convention's Chapter 1 would have taken effect.

On 11 November 2014, at the first reading of the bill, the spokesperson for the Liberals stressed that parliament, that very day, had written a small part of Denmark's history by adopting a paradigm shift to full dual-citizenship acceptance, as several other states had done. He explained by example how dual citizenship would benefit emigrants as well as immigrants. Lastly, he wished to point out that dual citizenship would make it possible for Denmark to expel Danish citizens who had committed crimes against the state - for instance, terrorism. If they had dual citizenship, he explained, they could be deprived of their Danish citizenship and expelled to their country of origin. Of course, he said, this was not the most important argument for acceptance of dual citizenship but was part of it. ${ }^{48}$

The spokesperson for the Social Democrats welcomed the Liberals' positive attitude and the positive bill, confirming that there was this "extra twist" in that the acceptance of dual citizenship might make it easier to expel persons who misused their citizenship, for instance by engaging in terrorism. The spokesperson for the Danish People's Party did not respond to the argument on denationalisation, etc. but, instead, maintained that a person can only have "one nationality, one fatherland, one identity, one mother

47 Ibid.

48 See the debate on 13 November 2014 at the first reading of the $L 44$, bill on the change to the Danish citizenship act, accessible here https://www.ft.dk/samling/20141/lovforslag/L44/ BEH1-18/forhandling.htm. 
tongue and one citizenship". ${ }^{49}$ The Social Liberals welcomed the broad acceptance of dual citizenship that they had fought for over many years. The Red-Green Alliance, the Socialist People's Party and the Liberal Alliance were equally happy. The Conservatives, who opposed the change, worried about the concept of national allegiance and loyalty. Furthermore, they envisaged several practical problems related to voting rights in more than one country, diplomatic protection, family relations and legal proceedings across borders. Lastly, they raised the question of multiple citizenship. The Social Democratic Minister for Justice concluded the debate by pointing out that, among other things, it was important to focus on integration and that, in this regard, citizenship meant a lot for very many people.

Thereafter, the bill was sent to the Naturalisation Committee for further consideration. During the committee's deliberations, the Danish People's representative, the then-chair of the committee, asked the Minister for Justice whether she expected that dual-citizenship toleration would entail an increase in the number of citizenship revocations and expulsions. The Minister explained that much would depend on the regulations in the countries of origin. In some countries, a person might lose his or her citizenship automatically on acquisition of a new citizenship; some might even choose to renounce their foreign citizenship. Besides, according to Danish law, proportionality was a precondition for citizenship revocation. Thus, it was difficult for the Minister to give a more specific answer to the question..$^{50}$

On 11 December 2014, the Naturalisation Committee submitted its report on the bill to parliament ${ }^{51}$ and the final parliamentary debate on the bill took place on 18 December $2014 .{ }^{52}$ Usually, a final debate is very brief and often no one asks for the floor. This time, however, the spokesperson for the Liberals wished to express his regret that parliament had not unanimously adopted the bill and repeated his earlier point that dual citizenship made citizenship revocation possible. ${ }^{53} \mathrm{He}$ was sorry that this argument had not gained a greater degree of acceptance. Following this and another brief intervention, parliament adopted the act on dual-citizenship acceptance with 89 votes for and 19 votes against.

49 The two pastors mentioned in Section 3 (Krarup and Langballe) had left parliament but had been succeeded by one of their children; among these latter, Christian Langballe, who was also a pastor, had become the party's spokesperson on citizenship matters and the chairman of the Naturalisation Committee.

50 See the Minister's answer of 02 December 2014 to Question 3 concerning Bill L 44, accessible here https://www.ft.dk/samling/20141/lovforslag/L44/spm/3/1423188/index.htm.

51 Naturalisation Committee Report on bill L 44 FT 2014-15, at: https://www.ft.dk/samling/20141/ lovforslag//44/bilag/10/index.htm.

52 The third reading, on 18 December 2014, of Bill L 44, can be found here https://www.ft.dk/ samling/20141/lovforslag/L44/BEH3-38/forhandling.htm.

53 The Liberals had also added this point to their reasons for dual-citizenship acceptance, mentioned in the Naturalisation Committee's report on the bill, cf. Footnote 51. 
The following year was an election year. At the general election in June 2015, the Social Democrats and their supporting parties received 49.3 per cent and the former opposition 50.7 per cent of the votes. Subsequently, the Liberals formed a single-party minority government. Under the new Liberal government, on 01 September 2015, the dual-citizenship act entered into force. ${ }^{54}$ The same evening, the expat organisation Danes Worldwide held a celebratory party to express their gratitude to those who had supported the acceptance of dual citizenship, among whom some Liberal politicians. ${ }^{55}$

\section{The Dual-Citizenship Act}

In accordance with the political agreement of 04 June 2014, the dual-citizenship act introduced access to dual citizenship for all Danes and foreigners, thus repealing all the Danish citizenship act's renunciation requirements. ${ }^{56}$

In addition, the act introduced a five-year time-limited transitionary arrangement for former Danish citizens who had lost their Danish citizenship through the acquisition of a foreign one. Former Danish citizens and their minor children (regardless of whether the children had been Danish or not) could (re)acquire Danish citizenship by declaration within five years of the date at which the dual-citizenship act entered into force. This transitionary possibility expired at the end of August 2020. ${ }^{57}$ However, in the Law Programme for the parliamentary year 2020-2021, the current Social Democratic government has announced that, in spring 2021, it will present a bill in parliament to restore the transitionary arrangement for former Danes for another five-year period (thus running until 1 April 2026). ${ }^{58}$ Notably, according to the transitionary arrangement, any former Danish citizen who is sentenced to imprisonment in the intermediate period, cannot re-acquire Danish citizenship by declaration. ${ }^{59}$ However, in certain cases, such

54 Act No. 1496 of 23 December 2014, amending the Danish citizenship act (acceptance of dual citizenship, etc.), accessible here https://www.retsinformation.dk/forms/r0710.aspx?id=167199.

55 See information about the celebration, accessible here https://hasseferrold.blogspot.com/ 2015/09/double-citizenship-from-19-2015.html\#!/2015/09/double-citizenship-from-19-2015. html. See also the magazine Danes No. 5, 2015, in which the Secretary General of Danes Worldwide expresses her gratitude to those who had worked for dual-citizenship acceptance. Among others, she thanked several Liberals in favour of dual citizenship who had convinced other more-reluctant Liberals. One of them was the former Minister for Integration, Bertel Haarder; another was Jan E. Jørgensen, the spokesperson of the Liberals, who had tried to convince the Danish People's Party by using the citizenship revocation argument.

56 Act on Dual Citizenship Section 1, repealing the Citizenship Act's Sections 4 A (1), 5 (2) and 7.

57 The Dual-Citizenship Act, Section 3(1). The transitional period expired on 01 September 2020.

58 Arguably, the need for a prolongation of the transitionary rule was foreseeable, see Ersbøll (2015). The Danish government's law programme for 2020-2021 is accessible here https:// www.stm.dk/statsministeriet/publikationer/lovprogram-for-folketingsaaret-2020-2021/.

59 The Dual-Citizenship Act, Section 3(2). 
a person may re-acquire it through naturalisation if acceptable to the Naturalisation Committee.$^{60}$ Reacquisition is only possible for persons who have lost their Danish citizenship through the acquisition of a foreign citizenship. The Citizenship Act's provision on the loss of Danish citizenship due to birth and residence abroad until the age of 22 still applies. ${ }^{61}$

Moreover, the dual-citizenship act introduced another transitionary rule, which expired at the end of August 2017. This rule applied to foreigners who had been naturalised conditionally since December 2012, dependent on their release from their foreign citizenship within a two-year period and who had not yet been granted such release. These persons could acquire Danish citizenship by declaration within two years of the date at which the dual-citizenship act entered into force. ${ }^{62}$

\section{Effects of dual-citizenship acceptance}

Before parliament's adoption of the dual-citizenship act, the government had estimated that dual-citizenship toleration would entail an increase in the number of naturalisations and cases of retention of Danish citizenship..$^{63}$ To some extent this proved correct although the full effects were not ultimately felt, probably due to the subsequent restrictions of the general requirements for naturalisation, agreed upon by the new political majority and the Social Democrats in 2015 and 2018. ${ }^{64}$

Figure 8.1 shows the huge variation in the annual grants of citizenship since 1993. The distinct increase in 2016 cannot be ascribed to the acceptance of dual citizenship as of September 2015 alone. To some extent, the increase reflects the effects of the general election, due to which the biannual bill on naturalisation was discontinued in 2015 and the accumulated number of applicants who naturalised by the end of the year were registered as Danish citizens in January 2016. Moreover, in spring 2016, two bills on naturalisation were adopted (instead of the usual biannual one), also due to the general election in 2015. Grants of Danish citizenship declined thereafter. Similarly, the 2018 - 2019 decrease and subsequent increase in 2020 may be attributed to effects of the 2019 general election.

60 This may be possible when the committed offence is not punishable by imprisonment in Denmark and when the waiting period provided for in the naturalisation circular for the committed offence has expired.

61 The Dual-Citizenship Act, Section 3(3).

62 The Dual-Citizenship Act, Section 4. The rule expired on 01 September 2017.

63 See the Ministry of Justice's estimation of 03 December 2014 concerning the additional costs in connection with the handling of cases on Danish citizenship, accessible here: https://www.ft.dk/samling/20141/lovforslag/L44/bilag/7/1431079/index.htm.

64 See Naturalisation Circulars Nos 10873 of 13 October 2015 and 9535 of 02 July 2018. 


\section{Figure 8.1. Acquisition of Danish citizenship, numbers per year}

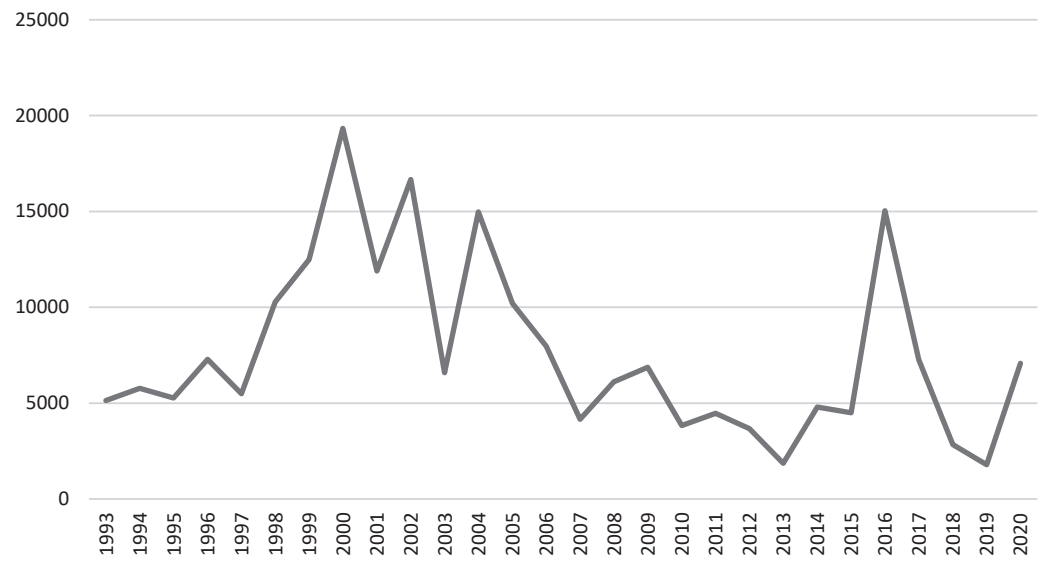

Danish emigrants have benefitted from the dual-citizenship reform, since they may now acquire the citizenship of their country of immigration without losing their Danish one. Moreover, many former Danes have used - and will probably within the coming years use - the (reinstalled) transitional option to re-acquire their lost Danish citizenship. About 600 immigrants and others have benefited from the other transitional arrangement that applied to persons who, between December 2012 and 01 September 2015, had been conditionally naturalised.

\section{Figure 8.2. Acquisition of Danish citizenship, share per year by region of origin}

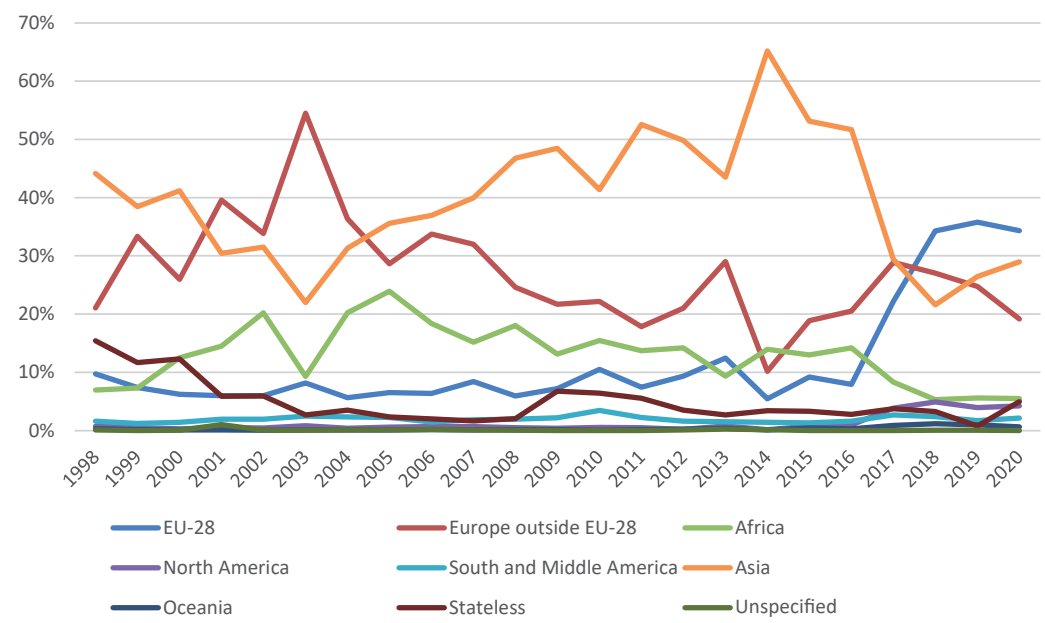


A clear result of the acceptance of dual citizenship is that the composition of the group of applicants for naturalisation has changed, as shown in Figure 8.2.

Figure 8.2 shows that, since 2014, the share of applicants from Europe and, in particular, EU member states has increased. This is no surprise, since Europeans - especially EU citizens with union citizenship rights - are generally not inclined to naturalise unless they can do so without losing their original citizenship. Nevertheless, there may be more specific explanations for the changes in acquisition rates.

Obviously, the number of applicants from the UK has risen due to Brexit. Up to October 2016, the biannual number of British citizens who naturalised did not exceed 20. However, within the last three years, citizens from the UK account for the highest share among the different nationalities who naturalise; for instance, the biannual naturalisation bill of October 2019 revealed that almost one seventh of the applicants were British (489 out of 3,566). Likewise, German citizens have naturalised increasingly since 2016. To some extent, this may be explained by the fact that, since 2018, Danish-minded Germans belonging to the Danish minority residing in Southern Schleswig (the German Land of Schleswig-Holstein) may, under certain circumstances, naturalise in Denmark (regardless of their residence abroad). ${ }^{65}$

Apart from Britons and Germans, Poles and Romanians in particular have increasingly applied for Danish citizenship, as have citizens from the US, Russia, Ukraine, Bosnia and Pakistan. Turkish citizens and stateless persons, including Danish-born stateless persons entitled to Danish citizenship by naturalisation, quite constantly naturalise. Against this, there has been a clear decrease in the number of naturalisations of citizens from Iraq, Afghanistan and Somalia - nationalities which, in the years 2014-2016, accounted for the highest shares of applicants for naturalisation. ${ }^{66}$ This decrease has, of course, to do with the shifting influx of refugees from Asia, the Middle East and Africa. ${ }^{67}$ However, the recent restrictions of the naturalisation requirements, agreed upon in 2015 and 2018, may also have played a role. ${ }^{68}$ After 2015 , there has not been much public debate about the significance of dual-citizenship acceptance. ${ }^{69}$

65 See Naturalisation Circular No. 9779 of 14 September 2018, as amended by Circular No. 9043 of 28 January 2020, annex 1, p. 5.

66 These nationalities were generally not affected by the dual citizenship reform since they were mostly refugees who had not been required to renounce their previous nationality.

67 Nationality lists are published together with the biannual naturalisation bills; see, for instance, the list of October 2019 (with 489 British applicants): https://www.ft.dk/samling/20191/lovforslag/L41/bilag/1/2094455.pdf.

68 Again, Denmark now has the toughest language requirement in Europe. For traumatised refugees and applicants with limited school attendance, this requirement may be difficult to fulfil. Furthermore, the conduct requirements have been strengthened unprecedentedly.

69 A small reservation may be that some dual citizens in Denmark have felt offended by an offer of financial support for repatriation from Denmark to their other country of citizenship. After an amendment in 2018, the repatriation act extended the group of beneficiaries of repatriation 


\section{Reflections on the Danish turn towards dual citizenship}

In the previous sections, I have outlined the Danish turn towards dual-citizenship acceptance. In my review of the political arguments for and against the policy shift, I have focused on arguments concerning integration and the possibilities for citizenship revocation and the deportation of terrorists.

I have brought the citizenship revocation aspect into focus because, in the recent literature on dual-citizenship acceptance, Denmark has been singled out as a country that has attached crucial importance to this angle. The Norwegian scholar, Arnfinn Midtbøen, has made this argument with reference to the recent Danish parliamentary debates on dual-citizenship acceptance. According to him (Midtbøen 2019, 300), the Danish debate "reveals that two distinct arguments for dual citizenship were used". First, that Denmark "should allow dual citizenship to allow Danish emigrants to keep or regain their Danish citizenship; in other words, a re-ethnicisation of citizenship, in Joppke's (2003) terms"; second, that "accepting dual citizenship would allow for citizenship revocation of dual citizens who engage in or support acts of terror".70

To boil down the Danish debate on and arguments for dual-citizenship acceptance in this way, in my opinion, gives a distorted picture of the background to and the reasons for Denmark's acceptance of dual citizenship. From the parliamentary debates on dual-citizenship acceptance over the last decade, it appears that - apart from the Danish People's Party - none of the political parties has taken a firm dismissive position on future dual-citizenship toleration. Some parties have been sceptical and many have wanted more information on the matter but most have welcomed the discussions of the issue. Notably, the Danish People's Party has constantly argued for its wholesale rejection.

Obviously, some political parties have had a more positive attitude towards dual-citizenship acceptance than others and, within each individual party, there have been different opinions - especially within the Liberal Party, which accounts for both conservative and more liberally oriented members. ${ }^{71}$ The Liberal spokesperson on the Naturalisation Committee, Jan E. Jørgensen, who put forward the citizenship revocation argument, is a "genuine liberal", ${ }^{72}$ while Inger Støjberg who, in 2015, became Minister for Immigration and Integration, has a national-conservative approach and several viewpoints similar to

aid to dual citizens who are released from their Danish citizenship within a two-year period in particular, dual citizens who were born and raised in Denmark have felt offended by being offered financial support for "repatriation".

70 The argument is repeated in Brochmann and Midtbøen (2020).

71 For more information about the Danish political parties and especially the Liberals see https:// www.yourdanishlife.dk/the-rules-of-the-game-the-danish-political-system-for-beginners/and https://www.thelocal.dk/20190510/the-locals-guide-to-denmarks-election-parties-part-onethe-right

72 Author of the book, A Genuine Liberal (in Danish: En Agte Liberal), accessible here https://www. arnoldbusck.dk/boeger/politik-debat/en-aegte-liberal. 
those of the Danish People's Party. In addition, the different parties' "bloc-alignment" has played a role - be it to the red or the blue bloc.

I have argued that it would not have been possible for members of the Liberal Party or the Conservative Party to fully commit themselves to dual-citizenship acceptance in the first decade of the twenty-first century, when the two parties governed the country with the support of the Danish People's Party. This viewpoint seems substantiated by statements from the Liberals, among which that from the former Prime Minister on the significance of the "present parliamentary situation", as quoted in Section 4. A commitment to dual-citizenship acceptance could have jeopardised the peaceful coexistence between the government and the Danish People's Party. Nevertheless, there seems to have been a general awareness that it was not a question of whether dual citizenship would be accepted but only of when. The window of opportunity opened after the general election in 2011, when the parliamentary party composition changed. Immediately, the new government took the position that it would accept dual citizenship. The commitment was inscribed in the government platform.

The new three-party government committed itself unconditionally to dual-citizenship acceptance and, in 2013, the Liberals endorsed the commitment. In the 2014 report, the ministerial working group on dual citizenship stressed the positive aspects of its acceptance for both emigrants and immigrants, as did the Minister for Justice in her subsequent announcement of the broad political agreement on the acceptance of dual citizenship. Consequently, the bill highlighted the positive aspects for emigrants as well as immigrants, as did the Liberal spokesperson in his presentation of the bill to parliament. ${ }^{73}$ Thus, I find it difficult to identify re-ethnicisation as a key argument for dual-citizenship acceptance. Rather, the debate was, in my opinion, characterised by a remarkable absence of attempts to "ethnicise" Danish citizenship - taking into consideration that ethno-cultural viewpoints have influenced the Danish citizenship debate both before (Ersbøll 2010) and after the debate on dual-citizenship acceptance, reflected inter alia in the law on the obligatory handshake in naturalisation cases. ${ }^{74}$

Certainly, in arguing for dual citizenship, the spokesperson for the Liberals outlined problems for Danes abroad (higher inheritance tax, job barriers and a lack of democratic rights); however, subsequently he mentioned problems for foreigners in Denmark - prob-

73 See the first reading of Bill L 44 at: https://www.ft.dk/samling/20141/lovforslag/L44/BEH1-18/ forhandling.htm

74 See the reasoning in the explanatory notes to the so-called "Handshake Act", Act No. 1735 of 27 December 2018 on the amendment of the citizenship act. According to the notes it is, in the opinion of the government, not in accordance with fundamental Danish values and respect for Danish society and culture norms if an applicant, during a naturalisation ceremony, refuses to shake hands with a representative of the Danish authorities; see notes to Bill L 80, 2018-19: https://www.ft.dk/samling/20181/lovforslag/l80/index.htm. 
lems that the Liberals would be ready to solve. ${ }^{75}$ It is true that the Liberal spokesperson rounded off by adding the controversial argument on better possibilities for citizenship revocation. However, he played down the importance of the argument by formulating it thus: "At last, I would also like to mention ... dual citizenship makes it possible to extradite Danish citizens who commit crimes against Denmark, for example terrorism. [...] this is of course not the most important argument for dual citizenship, but it is part of it". ${ }^{76}$ Arguably, this was first and foremost directed to the Danish People's Party. The Liberals were quite confident that they would re-occupy the post of Prime Minister after the forthcoming general election and, presumably, it would be convenient not to have too divergent opinions on this essential issue in the blue bloc. ${ }^{77}$

The former Liberal Prime Minister had experienced difficulties when asked to explain why the Liberals had changed their "position" or "attitude" and it came as no surprise that, in parliament, the Danish People's Party would also demand an explanation for the Liberals' policy shift. This might be forestalled by the citizenship revocation argument. Finally, the Liberals' spokesperson expressed his hope that the Danish People's Party might also change their minds. Although, realistically, this might be a lost cause, the representative of the Liberals yet again asked the party's representative whether the citizenship revocation argument did not make an impression; however, he did not even receive an answer concerning this viewpoint - which only the representative of the Social Democrats acknowledged as "an extra twist". ${ }^{78}$ More generally, however, she stressed that the bill would benefit very many people - both immigrants and emigrants.

Against this background, I cannot support the viewpoint that "the legal opportunity to strip terrorists from their Danish citizenship" was a key argument "that enabled Denmark's U-turn on the question of dual citizenship" nor the claim that this "argument created a new alliance between the left, the centre and the centre-right in Danish politics" (Midtbøen 2019, 301-302).

Of course, it is not possible to reject altogether the notion that the citizenship revocation argument has played any role. When questioning its significance, however, it is natural to rely on the Liberal spokesperson himself when, during the last reading of the

75 See the first reading of Bill L 44 at: https://www.ft.dk/samling/20141/lovforslag/L44/BEH1-18/ forhandling.htm.

76 lbid.

77 For the result of the 2015 election and the many seats of the Danish People's Party, see: https:// www.robert-schuman.eu/en/doc/oee/oee-1600-en.pdf

78 Notably, the Social Democrats knew that several general elections had been decided by the parties' viewpoints on immigration policies and that the Danish People's Party had won over many former Social Democratic voters with its restrictive immigration policy. In order to win these voters back, the Social Democratic Party was prepared to change its aliens policy accordingly (see Nedergaard 2017). 
bill on dual citizenship, he deplored the fact that the citizenship revocation argument had not gained a higher degree of acceptance.

Therefore, it seems fair to conclude that Denmark accepted dual citizenship in the context of international interdependence and largely for the same reasons that have influenced other states to accept it. Denmark was, as other countries have been (Vink et al. 2019), increasingly under pressure from expatriate organisations and expatriates who wanted to be able to naturalise abroad without losing their original citizenship. Danish expatriates' viewpoints on the importance of having access to dual citizenship seem to have had a spill-over effect for Denmark's immigrants.

\section{Future prospects}

Despite the above account of the Danish debate, I round off this chapter by examining whether the citizenship revocation argument might more generally be of significance for dual citizenship in the future. This is, among other things, motivated by the fact that Norway recently accepted dual citizenship with reference to the citizenship revocation possibility.

In this connection, I examine Midtbøen's argument $(2019,303)$ "that the urge to introduce citizenship revocation on the ground of terrorism in single-citizenship countries needs to be linked to acceptance of dual citizenship" and that this development "fundamentally challenges established theories of dual citizenship".

Midtbøen refers to an interview of 20 December 2017 with the Norwegian Minister for Immigration, who represented the Norwegian Progress Party - a sister party to the Danish People's Party. She linked dual-citizenship acceptance with the possibility of citizenship revocation in this way: "Dual citizenship is a prerequisite for depriving people of their Norwegian citizenship if they have committed terrorist acts or the like. This is one of the reasons why the Ministry for Justice now proposes allowing dual citizenship". ${ }^{79}$

On the same day, the Norwegian Ministry for Education and Research (responsible for integration) had sent out for consultation its proposal on the amendment of the Norwegian citizenship act..$^{80}$ The proposal argued that "loss of citizenship presupposes dual citizenship". ${ }^{81}$ Some of the organisations consulted opposed this angle, stating that they could not support the ministry's proposal to put such emphasis on the possibility of citizenship revocation. Still, the ministry maintained that such a loss would not have "full effect" without an amendment of the rule on single citizenship. According to the

79 See the interview of 20 December 2017: https://www.vg.no/nyheter/innenriks/i/BJI83E/aapner-for-dobbelt-statsborgerskap-for-aa-avskrekke-terror.

80 See Prop. 146 L (2016-2017) on the amendment of the citizenship act (acceptance of dual citizenship: https://www.regjeringen.no/no/dokumenter/horing-om-forslag-til-endringer-i-statsborgerloven--avvikling-av-prinsippet-om-ett-statsborgerskap/id2582695/?expand=horingsbrev.

81 lbid. 
department, dual-citizenship acceptance could contribute to the "prevention of terrorist activities in Norway" and that "the rules could prevent a Norwegian passport from being used, for instance, in terrorist activities". 82

With the proviso that I am not an expert on Norwegian citizenship legislation nor Norwegian politics in general, I assume that these statements reflect a given political context. Based on the experiences of the Danish Liberal Party, which had difficulty explaining its turn towards dual citizenship, I would guess that the Norwegian Progress Party - known for its restrictive immigration policy - might have faced similar explanatory problems when turning to dual-citizenship acceptance. ${ }^{83}$

In Norway, the Conservatives and the Progress Party had governed together since 2013. In 2017, the Liberals entered the government and the three parties decided on their government platform to accept dual citizenship. If the Progress Party had thought that their acceptance of dual citizenship might be a problem in the eyes of their constituents, they might have assumed that the possibility of citizenship revocation could alleviate potential criticism. This, of course, is only a hypothesis, based on the Danish case.

Anyhow, I remain unconvinced that the urge to introduce citizenship revocation on the grounds of terrorism in single-citizenship countries needs to be linked to the acceptance of dual citizenship. Neither am I convinced that the "securitisation of dual citizenship needs to be added to the mix of key drivers in the post 9/11 era" nor that we, for that reason, may be entering a third phase in the history of dual citizenship (Midtbøen 2019, 303).

Arguably, the citizenship revocation argument does not carry enough weight to be a key argument for dual-citizenship acceptance nor, vice versa, does dual-citizenship acceptance seem to be suited to securing the "full effect" of any citizenship revocation rule.

Taking some Danish politicians' statements as a point of departure, the shift to dual-citizenship acceptance is tantamount to a change to an "immemorial principle" and new "history writing". Arguably, the implied possibility of what may be a few more cases of citizenship revocation may not count for much in such a situation.

For the same reason, it is questionable whether dual-citizenship acceptance may secure the full effect of a citizenship revocation rule. Luckily, most countries have relatively few citizenship revocation cases caused by terrorism, so that dual-citizenship acceptance may not provide for many more revocation possibilities. Notably, the 1961 convention on the reduction of cases of statelessness and the ECN together prevent citizenship

82 See the Ministry for Education and Research's (Det Kongelige Kunnskapsdepartement) Prop. $111 \mathrm{~L}$ (2017-2018) Proposision til stortinget (forslag til lovvedtak), Endringer i statsborgerloven (avvikling av princippet om ett statsborgerskap): https://www.regjeringen.no/no/dokumenter/ prop.-111-I-20172018/id2608945/.

83 The Progress Party left the Norwegian government in January 2020 in protest after the Norwegian authorities, with the acceptance of the government, had let a so-called "ISIS wife" and her two children return to Norway from a Syrian detention camp. 
revocation in several cases, since they prohibit the rendering of people stateless and demand proportionality assessments. ${ }^{84}$ Dual citizenship is a by-product of migration (Spiro 2016). Therefore, in many countries that have only recently become countries of immigration, the clear majority of people are and will remain mono citizens. Notably, dual citizenship is always co-produced by two independent states (see Chapter 3 by Bauböck in this volume).

Regardless of whether or not a state fully accepts dual citizenship, the state may have a considerable share of dual citizens. As mentioned in Section 2, in several cases, international law demands that they accept dual citizenship. A person may become a dual citizen by birth or by extension when a parent naturalises or by his or her own naturalisation because renunciation of a foreign citizenship is not possible or is an unreasonable requirement. For these reasons, before Denmark and Norway accepted dual citizenship, 40 to 50 per cent of all their naturalised citizens had not been asked to renounce their citizenship of origin. Finally, dual citizenship is not an obligation but a right; dual citizens may apply for and be granted release from one of their citizenships. Thus, with or without dual-citizenship acceptance, some citizens may be deprived of their citizenship while others may be protected from it.

Against this background, the Danish Prime Minister has argued that to take care of Denmark, "we must start using means which we previously did not need nor want". ${ }^{85}$ Among such new means is a newly adopted exemption rule in the Danish foreign affairs act. This rule allows the Minister for Foreign Affairs to cut or limit Danish citizens' access to consular protection abroad if there is reason to believe that they have entered or stayed in a conflict area abroad without permission or have participated in activities that may imply a security threat. ${ }^{86}$ Thus, states may interfere in citizens' rights; not only Denmark but also other states have shown an unwillingness to take back their own citizens from conflict areas. Lastly, the Danish Minister for Immigration and Integration has announced that he will enter into a dialogue with the relevant organisations and like-minded countries with a view to strengthening the possibilities for citizenship revocation in relation to, for instance, foreign fighters. The starting point will be that the convention's protection

84 Therefore, two political parties in the Danish parliament have argued for non-compliance with the conventions and the Danish Social Democratic Prime Minister has expressed the viewpoint that "the conventions protect the wrong persons" - namely foreign fighters who have no place in Denmark (see the Prime Minister's statement during parliamentary question time: https:// www.dr.dk/nyheder/politik/se-hoejdepunkterne-mette-frederiksen-blev-grillet-af-de-andrepartiledere).

85 See the Prime Minister's statement in a newspaper interview: https://politiken.dk/debat/ledere/ art7477909/Igen-itales\%C3\%A6tter-Mette-F.-et-Danmark-i-eksistentiel-krise-truet-af-unavngivne-farer-som-nu-m\%C3\%A5-beskyttes-med-alle-midler.

86 See Section 2 of Act No. 23 of 28 January 2020 amending, inter alia, Section 1(4) in the act on foreign affairs: https://www.retsinformation.dk/Forms/R0710.aspx?id=212654. 
against statelessness in certain cases is too far-reaching. The minister has made clear that the over-extensive protection against statelessness is seen in cases where foreign fighters have only Danish citizenship. ${ }^{87}$

Summing up, for many countries, the turn towards dual-citizenship acceptance constitutes a momentous turnaround. Therefore, in my opinion, marginally better possibilities for citizenship revocation and expulsion can hardly qualify as a fundamental new rationale for dual-citizenship acceptance; likewise, the fact that several countries have introduced citizenship revocation as part of their counter-terrorism strategies hardly qualifies as a proper indicator of an emerging third phase in the history of dual citizenship.

\section{References}

Brochmann, G. and Midtbøen, A.H. 2020. Philosophies of integration? Elite views on citizenship policies in Scandinavia, Ethnicities. Available at: https://journals.sagepub. com/doi/pdf/10.1177/1468796820950453 (accessed 26 November 2020).

Ersbøll, E. 2010. On trial in Denmark, in van Oers, R., Ersbøll, E. and Kostakopoulou, D. (eds) A Re-Definition of Belonging? Language and Integration Tests in Europe. Amsterdam: Martinus Nijhoff, 107-151.

Ersbøll, E. 2015. Loss of nationality in the Nordic countries, in Carrera Nuñez, S. and de Groot, G.-R. (eds) European Citizenship at the Crossroads. Nijmegen: Wolf Legal Publishers, 212-213.

Fagerlund, J. and Brander, S. 2013. Country Report: Finland. Florence: EUDO Citizenship Observatory, Robert Schuman Centre for Advanced Studies.

Haugen, H.M. 2011. The Evangelical Lutheran Church in Denmark and the multicultural challenges, Politics and Religion, 4(03): 476-502.

Joppke, C. 2003. Citizenship Between De-and Re-Ethnicization. New York: The Russell Sage Foundation, Working Paper No. 204.

Jørgensen, J.E. 2018. A Genuine Liberal (in Danish: En ægte Liberal). Copenhagen: Forlaget Momenta. Available at: https://www.arnoldbusck.dk/boeger/politik-debat/ en-aegte-liberal.

Krarup, S. 1987. Kristendommen sætter nationaliteten (Christianity gives nationality), Tidehverv, 61: 25-26.

Lidegaard, B. 2014. A Short History of Denmark in the $20^{\text {th }}$ Century. Copenhagen: Gyldendal. Midtbøen, A.H. 2019. Dual citizenship in an era of securitisation: the case of Denmark, Nordic Journal of Migration Research, 9(3): 293-309.

87 See the Minister for Integration's answers of 09 June 2020 to Question 206 from the Immigration and Integration Committee (UUI Alm. Del) and of 26 June 2020 to Question 115 from the Naturalisation Committee: https://www.ft.dk/samling/20191/almdel/uui/spm/206/ svar/1668701/2206007.pdf and https://www.ft.dk/samling/20191/almdel/ifu/spm/115/svar/ 1675614/2217464.pdf. 
Nedergaard, P. 2017. The Immigration Policy Turn: The Danish Social Democratic Case. Available at: https://samf.ku.dk/presse/kronikker-og-debat/the-danish-social-democratic-case/.

Spång, M. 2007. Pragmatism all the way down? The politics of dual citizenship in Sweden, in Faist, T. (ed.) Dual Citizenship in Europe: From Nationhood to Societal Integration. London: Routledge, 103-125.

Spiro, P.J. 2016. At Home in Two Countries. The Past and Future of Dual Citizenship. New York: New York University Press.

Vink, M., Schakel, A.H., Reichel, D., Ngo, C.L. and de Groot, G.-R. 2019. The international diffusion of expatriate citizenship, Migration Studies, 7(3): 362-383. 


\title{
Chapter 9
}

\section{Dual Citizenship in Italy: An Ambivalent and Contradictory Issue}

\author{
Günther Pallaver, University of Innsbruck \\ Guido Denicolò, Avvocato dello Stato in Trento
}

\begin{abstract}
The discussion about dual citizenship in Italy was and is determined by a dominant theme. Primarily, this topic is related to questions of migration, in the sense of both emigration and immigration. After the Second World War, the problem of Italians in areas "lost in war" was added to this. Under these conditions, this chapter examines the case of Italy with a focus on the evolution of its citizenship law. Already in the first basic citizenship law of 1912 and although originally against dual citizenship, the young state wanted to maintain links with the large diaspora of Italian emigrants. Including Italians abroad as citizens across several generations was fully compatible with an ethno-cultural conception of national identity. Italy also permits the so-called italiani oriundi - i.e. persons of Italian ancestry living permanently abroad - to regain Italian citizenship if they can prove that none of their direct ancestors has explicitly renounced Italian citizenship. The second group of residents abroad for whom Italy promotes the restoration of citizenship are ethnic Italians in the neighbouring territories of Slovenia and Croatia, lost after World War II. Unlike for the italiani oriundi, these latter groups must establish a certain familiarity with the Italian culture and language. The final category discussed in the chapter are non-Italian immigrants whose numbers have been growing substantially since the 1990s. Although dual citizenship is tolerated in residence-based naturalisations, these are comparatively rare. Initiatives by the centre-left to introduce moderate forms of ius soli or ius culturae (naturalisation based on years of schooling) for the second generation have not thus far been successful.
\end{abstract}

\section{Introduction}

The discussion about dual citizenship in Italy was and is determined by a dominant theme. Primarily, this topic is related to questions of migration, both in the sense of emigration and immigration. After the Second World War, the problem of Italians in areas "lost in war" was added to this. The expulsion and flight of Italians from Istria (today Slovenia and Croatia), in particular, as a result of the Second World War still plays an important role in Italian domestic politics today (Pupo and Spazzali 2003). 
Additionally, the social narrative that prevails in Italy counts the state among those ("belated") nations that have developed a cultural conception of their identity with a partly ethnic colouring. In contrast to the civic nation, whose membership is fundamentally based on the criterion of citizenship, common political values and respect for institutions (cf. Haller, Raup and Ressler 2009), the ethno-cultural nation as an "ancestral community" is oriented towards (constructed) common descent, language, customs and traditions (cf. Lüsebrink 2009).

This social narrative of the nation, with a strongly cultural-linguistic and partly ethnic dimension, which developed during the unification of Italy (Risorgimento), was constantly renewed by the demand for the liberation and annexation of the terre irredente - the still unredeemed Italian territories outside the state borders - and was elevated to a state ideology by fascism. This view has a longue durée quality and is still dominant in wide political circles today (cf. Bollati 2011; Patriarca 2010; Tullio-Altan 1999). The shared link of the cultural nation is the ius sanguinis, which we discuss below, through which Italians remain connected with their nation even from outside Italy (cf. Haller, Raup and Ressler 2009).

In the debate on dual citizenship in Italy we are thus dealing with three categories of person, two of which have to do with migration: (1) Italians who have emigrated, (2) non-Italians who have immigrated to Italy and (3) co-ethnic minorities in a foreign state towards whom Italy acts as a protector kin state. The waves of emigration and immigration with which Italy has been confronted since its unification in 1861, as well as its kinstate policy in favour of its national minority in ex-Yugoslavia, have had a lasting influence on attitudes towards dual citizenship. This policy is characterised by openness towards Italians and closure towards foreigners. Such inward openness and outward closure are strongly linked to the ethno-cultural narrative of the nation, which runs like a thread through Italian citizenship policies.

\section{A rapprochement: Italy's emigration and immigration}

Thus far, Italy has had two major waves of emigration and is currently experiencing a third one. The first wave occurred between the unification of Italy (1861) and the end of the First World War. Between 1876 and 1915, Italy was one of the most important emigration countries in the world, with about 14 million Italians leaving their country - about one third of the population at that time (Associazione Internet degli Emigrati Italiani 2019). The second wave of emigration, involving about 4 million, took place after the Second World War and up until the 1970s (Albani and Pittau 2017; Marro 2019; Rosoli 1978). With the economic crisis starting in 2007, emigration has increased again but, this time, Italy is primarily experiencing a brain drain, with young and better-qualified citizens leaving the economically stagnating country (Colucci 2018). Between 1861 and 1985 - i.e. during the first and second waves of migration - almost 19 million Italians emigrated; today 
about 5 million Italians live abroad ${ }^{1}$ while, at the beginning of the 2000s, this figure was around 2.4 million (F.Q. 2019; Mancino 2019).

Between 2006 and 2019, Italian outmigration increased in absolute terms by 70.2 per cent from just over 3.1 million Italian citizens residing abroad registered in the AIRE (Anagrafe italiani residenti all'estero/Register of Italian citizens residing abroad) ${ }^{2}$ to almost 5.3 million (the number of Italian citizens living in foreign countries). This represents 8.8 per cent of Italy's population of around 60 million. Almost half of the Italians registered in AIRE come from Southern Italy (48.9 per cent, of whom 32.0 per cent are from the south and 16.9 from the islands); 35.5 per cent come from the north (18.0 per cent from the northwest and 17.5 from the northeast) and 15.6 per cent from the centre. Over 2.8 million (54.3 per cent) live in Europe and over 2.1 million (40.2 per cent) in America. The largest communities are located in Argentina, Germany, Switzerland, Brazil and France (see Table 9.1). They are followed (in per cent) by Great Britain (6.2), the USA (5.1), Belgium (5.1), Spain (3.4), Australia (2.8), Canada (2.6), Venezuela (2.1), Uruguay (1.9), Chile (1.1) and the Netherlands (0.9) (cf. Fondazione Migrantes 2019).

Table 9.1. Countries with the highest percentage of Italian citizens in 2019 (in \%)

\begin{tabular}{lcc}
\hline & Number & $\%$ \\
\hline Argentina & 842,615 & 15.9 \\
Germany & 764,183 & 14.5 \\
Switzerland & 623,003 & 11.8 \\
Brazil & 447,067 & 8.5 \\
France & 422,087 & 8.0 \\
\hline
\end{tabular}

Source: Fondazione Migrantes $(2019,25)$.

In 2019, mobility continues to mainly affect young people (18-34 years, 40.6 per cent) and young adults (35-49 years, 24.3 per cent). Of these recent emigrants, 71.2 per cent remained in Europe and 21.5 per cent emigrated to America (14.2 per cent to Latin

1 On 01 January 2019, 5,288,281 Italian citizens were registered at AIRE. More than half of them (51.5 per cent) are registered as emigrants but the numbers of those registered by birth abroad continues to grow (39.7 per cent). New acquisitions of Italian citizenship are 3.4 per cent (e.g. iure conubii), re-registrations due to unavailability are 4.0 per cent. The regulations are quite complex, since it is not necessarily true, for example, that all who are registered are Italian citizens by birth. In fact, a growing number are Italian-naturalised foreigners who, after a period in Italy, re-emigrate to a third country (cf. Fondazione Migrantes 2019).

2 AIRE also registers those who had moved their residence abroad before the law came into force. Registration in the AIRE is a legal obligation: (1) for Italian citizens who wish to transfer their residence abroad for more than 12 months; (2) for Italian citizens who were born abroad and have always lived outside the Italian territory; (3) for those who acquire Italian citizenship abroad (see Ministero degli Affari Esteri e della Cooperazione Internazionale 2020a). 
America). In 2018, the United Kingdom was the first destination with over 16 per cent of migrants $(20,596)$ (an increase of 11.1 per cent compared with the previous year). Germany comes second with 14.3 per cent $(18,385)$, followed by France with 10.9 per cent $(14,016)$, Brazil with $9.1(11,663)$, Switzerland with $8.0(10,265)$ and Spain with 5.9 per cent (7,529) (Fondazione Migrantes 2019).

The General Directorate for Italians Abroad and Migration Policies (in the Ministry of Foreign Affairs (cf. Ministero degli Affari Esteri e della Cooperazione Internazionale 2020b) and the globally active COMITES - Comitati degli Italiani all'Estero - take care of Italians abroad. The committees, founded in 1985, are representative bodies of Italians abroad and are elected in each consular district. In addition, there are many private associations which also organise Italians who no longer have Italian citizenship - e.g. Trentini nel mondo, Calabresi nel mondo, Veneti nel mondo, etc. (see Ministero degli Affari Esteri e della Cooperazione Internazionale 2020c). All these organisations form a capillary network that maintains the ethno-cultural link with the Italian nation.

Table 9.2. Countries of origin of foreign citizens in Italy 2019 (in \%)

\begin{tabular}{lrc}
\hline & Number & $\%$ \\
\hline Romania & $1,206,938$ & 23.0 \\
Albania & 441,027 & 8.4 \\
Morocco & 422,980 & 8.0 \\
China & 299,823 & 5.7 \\
Ukraine & 239,424 & 4.6 \\
\hline
\end{tabular}

Source: Tuttitalia (2019).

In addition to emigration, there has also been immigration. After 1945, Italy had to take in Italians who had fled or had been expelled from Istria. Then, in the 1960s, there was another flow of immigration from the former Italian colonies. Immigration started to diversify in terms of origins with the fall of the Iron Curtain and new arrivals from Central and Eastern European states (e.g. from Albania, Romania, Ukraine) until immigration became truly globalised around the turn of the millennium. In 2001, immigration reached 1 million; by 2019, 5.2 million foreigners lived in Italy according to official statistics, of whom 50 per cent ( 2.6 million) came from a European country, 21.7 per cent from Africa (1.1 million), 20.8 per cent from Asia (1.09 million) and 7.2 per cent from the Americas $(380,000)$. The strongest contingent of foreign nationals in Italy are Romanians, followed by Albanians, Moroccans, Chinese and Ukrainians (see Table 9.2). They are followed (in per cent) by migrants from the Philippines (3.2), India (3.0), Bangladesh (2.7), Moldova (2.5) and Egypt (2.4) (see Tuttitalia 2019).

The official figure of just over 5 million foreigners includes a further 400,000 persons who hold a regular residence certificate but are not registered in any municipality in 
Italy. In 2019 approximately 100,000 asylum-seekers and an estimated 560,000 undocumented migrants have to be added to this figure. All in all, this increases the number of foreigners in Italy to about 6.2 million or 10.3 per cent of the total Italian population (cf. Colombo 2019).

Foreigners in Italy (according to data for 2018), as well as the undocumented migrants mentioned above, are employed primarily in so-called "other services" (36.6 per cent in, for example, care work, deliveries, cleaning, logistics and so on), followed by service in hotels and restaurants (17.9 per cent), work in agriculture (17.0) and construction (17.2). About 90 per cent are in dependent employment and about 80 per cent are manual workers (Diodato 2020; Ministero del Lavoro e delle Politiche Sociali 2019a).

Italy as a classic emigration country has become one of immigration since the 1970 s. This is essentially due to drastic, international economic transformation processes. The collapse of the Bretton Woods System in 1973 and the oil crisis of the same year were major causes of this change. One of the consequences was that the countries of Central and Northern Europe stopped taking on new workers. Italy and other Mediterranean countries thus became a second-best solution for all those who were looking for new prospects in life.

Italy had several advantages for those, mainly from non-European and Eastern European countries, who wanted to immigrate. The approximately $8,000 \mathrm{~km}$ of coastline cannot be closely controlled and the legal basis for immigration, which was virtually non-existent until the early 1980s, encouraged uncontrolled immigration from abroad. Many of these migrants still find jobs in the informal labour market (cf. Ginsborg 1998).

Italy is a "young" immigration country. Three out of four immigrants came to Italy as adults. In contrast to the other OCSE countries, Italy has a relatively small number of second-generation foreigners. These amount to 0.4 per cent of the population of Italy, compared to the EU average of 3.4 per cent (Ministero del Lavoro e delle Politiche Sociali 2019a).

\section{Status civitatis}

Citizenship (status civitatis) is generally understood to be a special relationship between the state and the individual. The modern concept of citizenship in Italy begins with the political unification of the country in 1861. The unitary state had always attributed a central and exclusive importance to citizenship and therefore excluded dual citizenship. The first steps to regulate this complex matter were taken shortly after unification in 1865 with regulations in the Civil Code (Articles 1-15). This strong ethno-cultural bond between the state and its citizens (initially only male citizens) is the foundation on which citizenship regulations are built. We find this logic in the age of nationalism not only in Italy but, in Italy, the experience of migration that we have documented above has had a more prominent impact than in most other nation states. 
The regulation of citizenship in Italy is based on two fundamental laws. The first, which is no longer in force, dates back to 1912 and does not, in principle, exclude dual citizenship. This new orientation, in contrast to the regulations introduced in 1865, is based on the experience of Italian emigration and the goal of maintaining links with the Italian "diaspora" and the possibility of returning to the "national community". Despite several amendments, the law remained in force until the new citizenship law of 1992. Thus, a person born abroad could acquire a foreign citizenship iure soli without losing his or her Italian one but could renounce the latter after coming of age.

It is worth mentioning that the law gave men an absolute priority over women with regards to citizenship status. This meant that the citizenship of the entire family was linked to that of the man, the husband and father. Thus the status civitatis of the wife and children changed automatically when that of the husband changed. The wife could never have any other citizenship than that of her husband. An Italian female citizen who married a foreigner lost her citizenship. If the marriage was dissolved, the wife would get her Italian citizenship back if she resided in Italy and declared that she wanted to regain her former citizenship. A two-year residence in Italy since the dissolution of the marriage counted as the equivalent of the declaration.

The law on Italian citizenship of 1912 (Legge 1912, No. 555) was replaced only by the law of 1992 (Legge 1992, No. 91). The 1992 Act, which has also been amended several times, still retains elements of the 1912 Act and demonstrates more than 100 years of continuity in the toleration of dual citizenship, as the rules in this area are based on norms and values that were already in force before 1912. In contrast to the law of 80 years ago, the new law, which is still in force today, emphasises the centrality of the individual's decision to acquire or lose citizenship, introduces equality between men and women (already established by the Constitutional Court in its judgments No. 87/1975 and 30/1983) and recognises the right to dual citizenship. In total there are four basic principles on which the 1992 law is based:

1. the transfer of citizenship by descent (principle of ius sanguinis);

2. the acquisition of Italian citizenship by birth on Italian territory (ius soli) but only in very specific cases;

3. the general toleration of dual citizenship; and

4. the right of individuals to apply for the acquisition or renunciation of Italian citizenship (see Ministero degli Affari Esteri e della Cooperazione Internazionale 2019).

\section{How to become an Italian citizen}

Today, the acquisition of Italian citizenship is regulated by State Law No. 91 of 05 February 1992 and by subsequent regulations (Legge 2000 and Legge 2006). The decrees of the President of the Republic DPR No. 572 (12 October 1993) (DPR 1993) and DPR No. 362 
(18 April 1994) (DPR 1994) regulate the implementation of the law. The conditions for acquiring citizenship are:

1. ius sanguinis: in principle, Italian citizenship is acquired by descent from at least one Italian parent (ius sanguinis). Minors acquire Italian citizenship if their descent from an Italian citizen is recognised or established by a court of law or if they are adopted or their parents acquire Italian citizenship;

2. ius soli: in exceptional cases, acquisition iure soli (i.e. by birth on Italian territory) is granted if the child's parents are stateless or unknown. This is also the case for children of foreign parents whose citizenship is not transmitted to their children iure sanguinis;

3. ius conubii: citizenship is acquired by marriage or by cohabitation based on the law of 2016 (Unione di fatto/de facto union);

4. ius domicilii: citizenship is also acquired through a long period of residence (ius domicilii). EU citizens can apply for citizenship after four years if they have resided in Italy without interruption; all others after ten years. This rule also applies to children of foreigners born in Italy who have lived in Italy without interruption until the age of majority (18 years). Political refugees and stateless persons must be resident for five years without interruption; and

5. merits: acquisition is also possible due to merits on the basis of special laws by a decree of the President of the Republic (Legge n. 91/1992 modificata dalla legge $n$. 94/2009) (Legge 2009).

After 1992, marriage still remained the privileged access to citizenship, which could be applied for only six months after marrying an Italian. In 2009, however, this part of the law was amended by the Berlusconi government, increasing the period from six months to two years (Camilli 2017). Additionally, the 1992 law shows the political weight of Italians living abroad and their lobby - they have been granted the "right to vote abroad" by the 2001 law (Legge 2001) and can elect six senators and 12 MPs via four foreign constituencies. ${ }^{3}$ This has further increased the distance between the rights of Italian citizens living abroad and those of foreigners residing in Italy (Zincone 2010).

It is no coincidence that the proposal for the "foreign electoral law" - with its unique division of the whole world into electoral districts - originated from the former neo-fascist party MSI (Movimento Sociale Italiano). In 1968, prominent members of the party founded the "Comitati Tricolori per gli Italiani nel Mondo" (Tricolour Committees for Italians in the World) for the purpose of maintaining the italianità (italianness) of Italians living abroad. In 1989, on the initiative of MSI party representatives, a law was passed to create a consultative body of the government and parliament for Italians abroad

3 The constitutional referendum of 20 and 21 September 2020 reduced the number of deputies from 12 to 8 and the number of senators from 6 to 4 . 
(Consiglio Generale degli Italiani all'Estero or CGIE). In 2001, under the Berlusconi III government (2001-2006) and with MSI member Mirko Tremaglia as Minister for Italians in the World, the law on voting rights abroad was passed. The Berlusconi government, under the leadership of this minister, passed the law on dual citizenship for Italians in the former Yugoslavia in 2006 (see Camera dei Deputati 2020).

\section{Dual citizenship}

The experience of strong migration flows has influenced the toleration of dual citizenship. As we will see, this fact affects Italians abroad, either because they have emigrated or because they had lost their Italian citizenship as a result of the war. Contrary to the 1983 law (whose exclusion of dual citizenship was already mitigated by the 1986 law (cf. Legge 1983 and Legge 1986), ${ }^{4}$ in 1992 and by subsequent amendments or additions (laws of 2000 and 2006), the right to hold several citizenships simultaneously was fully recognised.

Italy has thereby performed a u-turn. In 1963, Italy had acceded to the European Convention on the Reduction of Cases of Multiple Nationality and on Military Obligations in Cases of Multiple Nationality. In principle, this treaty rejects multiple citizenships, insists that the previous citizenship is lost if the nationality of another member state of the convention is acquired and prohibits the signatory states from authorising citizenship retention (cf. Council of Europe 1963). However, like other signatory states, Italy has never really implemented the 1963 Convention and formally denounced the first part of it in 2009. Since then, it has been bound only by the provisions relating to military service. At the same time, Italy enacted a series of regulations that allow foreigners to acquire Italian citizenship with a more-or-less explicit emphasis on their italianità. Without the possibility of dual citizenship, it would have been difficult for Italy to encourage "foreign Italians" to take this step if they had to renounce their current citizenship.

The possibility of dual citizenship was already included in the 1992 law, but the laws of 2000 and 2006 significantly expanded the numbers of eligible persons. This applies to the regulations concerning the descendants of former Austro-Hungarian citizens and to the descendants of Italian Yugoslavs, which did not require the renunciation of their current foreign citizenship as a condition for the granting of Italian citizenship.

On the whole, it can be said that there has been - and partly still exists - a bipartisan consensus across the Italian political camps that is motivated in different ways but cultivates the myth of "L'Altra Italia" (the other Italy outside the state borders). The "right" can thereby boast of a larger Italy and the "left" can pay tribute to the emigrated working class (Zincone 2010, 17).

4 The two laws of 1983 and 1986 were only a short and insignificant intermezzo on the way to the 1992 law. 


\subsection{Oriundi italiani ${ }^{5}$}

The first law on citizenship after the unification of Italy in 1861 was based on the principle that membership of a society was linked to membership of a nation, a community of people with the same ancestors. Like other countries with a high number of migrants, Italy has therefore established the transfer of citizenship via ius sanguinis in order to maintain a link with the many emigrants (Zincone 2010). However, ius sanguinis initially had no direct connection to migration and only gradually became a topical issue again through it.

Italy has taken this logic into account with its 1912 law, which allowed dual citizenship under certain conditions (Legge 555/1912) in order not to break off contact with "foreign Italians". This objective remained apparent even after the 1912 Act was repealed by the 1992 Act. The latter explicitly confirmed in Article 20 "the status of nationality acquired before that Act, except in respect of events occurring after the date of entry into force of that Act".

The legislator de facto assumes that descendants of Italian citizens always retain their citizenship on the basis of ius sanguinis (if one parent is a foreign citizen) even if they have acquired another citizenship, unless they have explicitly renounced their Italian one. This implies that descendants of Italian citizens who, for generations, never cared about Italian citizenship can apply for its recognition since the law assumes that they actually never lost it.

In a circular of 27 May 1991, the Ministry of the Interior explained that the law refers to the recognition of citizenship for those foreigners who have emigrated to countries where the (foreign) citizenship is automatically acquired on the basis of ius soli there. Article 7 of the 1912 law explicitly provided that "except for specific provisions to be laid down in international treaties, Italian citizens born and resident in a foreign State and recognised as its citizens by birth shall retain Italian nationality but may renounce it upon attainment of majority or maturity".

The Law of 1912 thus provided for the recognition of Italian nationality on the basis of paternal ancestry (or later also maternal, see below), regardless of place of birth. This claim could be waived once the person reached the age of majority. The prerequisite for re-establishing Italian citizenship is therefore proof of descent from the person originally endowed with citizen status as well as proof of the absence of interruptions in the transfer of citizenship, which could only happen by explicit renunciation.

Thus, if a child of an Italian citizen obtained the citizenship of the state of residence on the basis of ius soli, the child retained his or her Italian citizenship, even if the father lost his citizenship after the birth of the child and while the latter was a minor. Italy refers to these cases as oriundi (natives). Such persons with dual citizenship who were subject to the rules of the 1912 law did not have to choose one or the other citizenship,

5 "Latent Italians", people of Italian origin (see Zincone 2010, 5). 
as later provided for by Law No. 123 of 1983. This latter law was replaced by the already mentioned 1992 law and the obligation to choose was cancelled. Citizenship was thus transferred from generation to generation, even if the individual person had never taken care of it or was never aware of it.

This rule was also applied retroactively to children born abroad to Italian mothers who were Italian citizens at the time of their birth - especially to children born out of wedlock - since wives generally lost their citizenship of origin by marrying a non-Italian husband. ${ }^{6}$ A person only had to prove to be the descendant of an emigrated Italian and that there was no interruption in the chain of transferring citizenship.

Applying for Italian citizenship according to these provisions involves the following procedural requirements:

1. Descent from an Italian citizen must be proved without any intergenerational interruption.

2. It must be proven that the Italian ancestor has retained his/her Italian nationality until the birth of the descendant.

3. The lack of naturalisation - i.e. the acquisition of foreign citizenship or the date of an eventual naturalisation of the ancestor - must be established by a certificate from the relevant foreign authority. ${ }^{7}$

4. The origin of the Italian ancestor must be proven by birth and marriage certificates. In this context, it should be noted that the transfer of Italian nationality on the mother's side could initially only be carried out for children born after 01 January 1948, the date on which the Italian Constitution came into force. However, this restrictive view was successively corrected by the Court of Cassation so that citizenship by descent from the mother is, in principle, also applicable to children born before the entry into force of the Italian constitution, unless the mother had previously spontaneously and voluntarily renounced her Italian citizenship.

5. It must be confirmed that neither the applicant nor his or her ancestors have ever renounced Italian citizenship and have thus not interrupted the chain of transfer of citizenship by submitting appropriate certificates from the relevant Italian diplomatic authorities (Peterlini 2019).

${ }^{6}$ Constitutional Court rulings in Italy are always retroactive and, in this case - as repeatedly stated by the Court of Cassation - even back to the time before the Constitution came into force (1948). Gender equality was first established in the 1948 Constitution.

7 However, if the naturalisation was voluntary, this led to the loss of Italian citizenship. Most Italian first-generation emigrants did not acquire foreign citizenship or acquired it relatively late, sometimes automatically through marriage, while their children born abroad very often acquired citizenship on the basis of ius soli - i.e. automatically and independently of their own will. 
As already mentioned, 1861 - the year of Italy's unification - is considered a time constraint. At that time, Italy had about 28 million inhabitants. According to estimates by the Ministry of Foreign Affairs, about 80 million "Italians" could apply for citizenship today - i.e. more than the 60 million Italian citizens that there are today. In terms of geographic distribution of the oriundi, around 25 million live in Brazil, followed by Argentina (20), USA (18), France (4), Canada (1.5), Uruguay (1.3), Venezuela (0.9) and Australia (0.8). So far, however, the number of those interested in taking up the citizenship offer has been limited to around 300,000 applications (Ciocca 2019).

In summary, the following can be said about the 1912 law and its timid toleration of dual citizenship. The law reaffirms the principle of ius sanguinis as the main reason for access to citizenship. Dual citizenship was allowed for minors born abroad in a ius soli country but they could opt for one of the two citizenships and were not obliged to decide until they reached the age of majority. In view of the high level of emigration, the Italian parliament opted for an ambivalent position, for a compromise between tolerating dual citizenship and maintaining close ties with its descendants abroad. Dual citizenship was thus tolerated, although not accepted explicitly. This applied when the acquisition of the second nationality was automatic and inevitable, as in immigration countries with ius soli provisions. In this way, for many emigrants, Italian citizenship became a kind of "substitute nationality" that could be used when needed. This attitude of the liberal governments in Italy was radically interrupted when fascism seized power in 1922 (Zincone 2010).

\subsection{Citizenship for Italians in "lost territories"}

The current Italian citizenship regulations (Legge 1992, 2000, 2006) ${ }^{9}$ do not exclude multiple citizenships and even consciously accept them - as the regulations state - in recognition of the changed world situation and the resulting "anachronistic" character of an "exclusive concept of citizenship" that runs counter to the "widespread tendencies in the relevant European legislations, starting with Italian legislation". ${ }^{10}$

In fact, as already mentioned, Italy not only denounced Chapter I of the 1963 Convention with effect from 4 June 2010 (Circolare 2009) - which had de facto never been implemented at national level - but already before that enacted a series of regulations enabling foreigners, with more or less clear emphasis on their italianità, to acquire Italian citizenship without having to renounce the previous one. This applies in particular (see

8 There are different data and estimates on this issue. Zincone speaks of around 60 million "oriundi". Between 1998 and 2007, according to the ministry's calculations, around 800,000 people outside Italy applied for Italian citizenship (Zincone 2010,5).

9 A useful overview, also with a small comparative law section, can be found in Dossier No. 239/2015 of the "Servizio studi del Senato" (2015). See Senato della Repubblica (2020).

10 Written answer of 15.12.2008 to Parliamentary Question No 4-01176 (Chamber of Deputies) by Alfredo Mantica, then Under-Secretary of State at the Ministry for Foreign Affairs: www.camera. it/_dati/lavori/stenografici/sindisp/framesed.asp?sed=057\&min=02 (28.03.2018). 
Legge 2000) to the former citizens of the Habsburg Empire and their descendants who were "born and resident" in the territories currently belonging to Italy or in former Italian territories later ceded to Yugoslavia (Peace Treaty 1947 and Osimo Treaty 1975) and who emigrated before 16 July 1920. Excluded from this possibility, however, are those who emigrated to the territory of the present-day Republic of Austria before the mentioned deadline; under this provision, they are not entitled to acquire Italian citizenship.

A definitive opening towards dual citizenship for Yugoslav citizens of Italian nationality took place with the 1992 law. From that moment onwards, applications for an Italian passport could be made by persons born in territories formerly belonging to Italy which had been ceded to Yugoslavia on the basis of the 1947 Peace Treaty and the Osimo Treaty of 1975 which concerns the former Zone B of Trieste. Later, the Italians in Yugoslavia demanded that this right to dual citizenship be extended not only to those who had been born during this period but also to their descendants. As can be seen, there was no explicit ethnic link for the group of persons covered by this legislation. It refers exclusively to birth and residence in a particular territory and to the fact of emigration before a historical reference date.

In 2006, the possibility of acquiring Italian citizenship without renouncing one's present foreign citizenship was opened up to former Italian citizens living in territories which were ceded to Yugoslavia and which today belong to Slovenia and Croatia, as well as to their direct descendants of "Italian language and culture" (see Legge 2006). In their case, an explicit link is made to a linguistic-cultural condition that comes considerably close to an ethnic characterisation of the beneficiary group. The law uses different references to italianità for the "ancestors of origin" and their descendants. For the former, in addition to previous Italian citizenship and residence in the ceded territories, it is required that they meet the conditions for opting between the old and new citizenship that was already provided for in the respective treaties. This concerned the descendants of those persons who had not at that time opted for Italian citizenship within the time limits laid down in the respective treaties. These could "re-opt" if their ancestors could have opted but failed to do so. However, now it is not enough for them to have ancestry, they must also show current characteristics of their italianità.

The 1947 Peace Treaty (Article 19 (2)) only refers to persons whose "ordinary language is Italian" ("la cui lingua usuale è l'italiano") (Trattato di pace 1947), whereas the 1975 Osimo Treaty (Article 3) (see Trattato 1977, Art. 3) already speaks of persons who are "part of the Italian ethnic group" ("parte del gruppo etnico italiano") and distinguishes them from persons of the "Yugoslav ethnic group". It remains unclear who precisely belongs to the latter group given the linguistic, national and religious diversity of multiethnic Yugoslavia at that time.

Direct descendants of the aforementioned "ancestors" - who were also taken into account in the law of 2006 - must, however, prove that they are of "Italian language and culture", without the legislator itself directly specifying this condition. This was finally 
clarified by the Italian Ministry of the Interior's own circulars, both for the relatives in former Austrian territories and for the inhabitants of the territories "lost" to ex-Yugoslavia. Nationals of the Dual Monarchy who emigrated between 1867 and 1920 and who were resident before 16 July 1920 in the territories currently belonging to Italy and annexed to Yugoslavia by the Peace Treaty of 1947 and the Osimo Treaty of 1975 must, among other documents, provide "certificates" issued by Italian "circles, associations, communities" present at the foreign place of residence of the applicant, which show "suitable elements" of their italianità.

The following assessment guidelines are listed as examples: "level of common knowledge" ("livello di notorietá") - that the applicants and their ancestors belong to the "Italian ethnic-linguistic group", declaration of "national belonging", date of beginning of "membership" in the certifying institution and any other useful documentation on their affiliation with the "Italian ethnic-linguistic group", such as school attendance certificates, school reports, family correspondence (Circolare 2001, 2006). In a certain sense it was a kind of "reconquest" of persons on the basis of ethnonational standards.

This "ethnicisation" of citizenship took place during the governments of Berlusconi, especially between 2001 and 2006 with Alleanza Nazionale (AN) as a coalition partner. This successor party to the neo-fascist Movimento Sociale Italiano (MSI) had always distinguished itself by a nationalist policy not only in favour of the Italians in Slovenia and Croatia but also by its claim for the recapture of the territories lost to Yugoslavia after the Second World War. The party secretary of AN, Gianfranco Fini, was Foreign Minister in Berlusconi-led governments from 2004 to 2006. The same Fini, then Party Secretary of the MSI, together with the leader of the party in Trieste, had thrown a bottle painted with the colours of the Italian flag into the sea on the coast of Istria on 08 November 1992 with the message: "It is also our oath: 'Istria, Fiume, Dalmatia: we will return!'" (Martocchia 2009). From 2001 to 2006, Mirko Tremaglia, an exponent of AN and formerly of MSI, was the Ministro per gli Italiani nel Mondo (Minister for Italians in the World). Tremaglia was considered the representative par excellence of the "italianità" (Ministero degli Affari Esteri e della Cooperazione Internazionale 2012).

These were the political conditions and the political climate that accompanied the creation of the 2006 law. The recourse to ethnicity and italianità was repeatedly expressed in the debate surrounding this law. It already began with a draft law of 2002, in which Article 1 immediately referred to the Italians concerned as an "ethnic group" (Camera dei Deputati 2002) or later on to the "right of blood" to citizenship (Camera dei Deputati (2004). Even after the law was passed, this wording remained the same (Camera dei Deputati 2008), to quote just a few examples.

The possibility to apply for Italian citizenship for Italians in Slovenia and Croatia was offered unilaterally by Italy without consulting with the two governments. The result was diplomatic disgruntlement with Italy but the Croatian church also expressed reservations. Ljubljana and Zagreb spoke of a new "imperialism of Italy" that wanted to reconquer its 
lost territories. The primary fears were that the restoration of Italian citizenship would provide a pretext for the extreme right to demand a revision of the state treaties.

At this point it is important to look at the international practice whereby states often take measures in favour of their own ethnic minorities in a foreign state, which go as far as granting citizenship. The granting of citizenship falls within the exclusive competence of the state (cf. Kochenov 2019) but the question is where the line is drawn between interference in favour of minorities outside a state's own territory and a commitment to good neighbourly relations and non-interference in the internal affairs of other states.

A number of international documents stipulate that minority protection is also an international and not just a purely domestic matter. An important foundation for this is provided by the "Bolzano/Bozen Recommendations on National Minorities in Inter-State Relations" (cf. OSCE 2008), the guidelines for which are soft law and not binding but which are used for the interpretation of harder legal norms. Thus, not all measures in favour of minorities in another state have the same relevance. The awarding of citizenship to a numerically significant minority in a state with which the kin state is in conflict has different implications than, for example, financial support to a minority for cultural purposes (Palermo 2020).

Such contradictions and conflicts in the balance between good neighbourly relations, restraint in interfering with other states' domestic affairs and granting rights to the "foreign minority" emerged in the relationship between Italy on the one hand and Slovenia and Croatia on the other. The Italian state grants the Italians in Slovenia and Croatia the right to apply for Italian citizenship. However, Italy has protested against Austria's proposal to grant Austrian citizenship to German- and Ladin-speaking South Tyroleans (see Atz and Haller's Chapter 14 in this volume; aslo Denicolò and Pallaver 2018). The two cases are very different - especially in their numerical dimension - but Italy's position seemed somewhat incoherent.

We find the same contradiction in Croatia, which protested against the granting of dual citizenship to its Italian minority but applied a similar policy to the Croats in Bosnia, who make up 18 per cent of the population there. However, Croatia was unable to put up too much resistance to Italy's plan as, during those years, Croatia was conducting negotiations for EU accession and wanted to avoid an Italian veto (Palermo 2020).

We can see, particularly in the relationship between Italy and Croatia, that the granting of dual citizenship by kin states to their foreign minorities is often less based on international rules and good neighbourly relations than on power relations. In view of the strong ethnonational tendencies of the Italian legislator in that period, when the centre-right governments under Silvio Berlusconi with the post-fascists of Alleanza Nazionale were in power. This may also help to explain why Italy initially signed the European Convention on Nationality of 1997 but has not ratified it until now, since Article 5 of the Treaty provides that the provisions of a Contracting State relating to nationality "shall not contain distinctions or include any practice which amounts to discrimination 
on the grounds of sex, religion, race, colour or national or ethnic origin" (Council of Europe 1997, Art. 5).

In strictly numerical terms, these rules concern relatively few persons. Following the exodus of the Italian population between 1945 and 1960 (Wörsdorfer 2009), there are now around 2,500 Italians living in Slovenia and around 20,000 in Croatia. About 20,000 of them have Italian citizenship in addition to Slovenian and Croatian citizenship - thus, dual citizenship (Liberto 2018).

\section{A new approach: ius culturae}

After various failed attempts to facilitate access to citizenship for foreigners in Italy, a novel principle of ius culturae was given greater prominence alongside ius soli and ius sanguinis. The ius culturae links citizenship to school attendance, which is regarded as a central factor of socialisation leading to the acquisition of "Italian culture" (Forlati 2019). According to a draft law of 2015, a minor foreign citizen who was born in Italy or who arrived in Italy before the age of 12 and attended school for five years on a regular basis or attended vocational training courses for three to four years in order to obtain a vocational qualification should receive Italian citizenship. This also applies to children who have successfully completed five years of primary school or at least one school cycle (primary or secondary school) (UNICEF 2019). In addition to the ius culturae, the draft law also provided for a conditional ius soli. Anyone born in Italy to foreign parents, at least one of whom has a permanent residence permit or an EU long-term residence permit, should be able to apply for Italian citizenship (Carmagnani and Pastore 2018; Ministero del Lavoro e delle Politiche Sociali 2019b). Under the conditions indicated, these persons would have a direct entitlement to citizenship (see Senato della Repubblica 2015).

The final breakthrough should then have taken place in the previous legislative period. A bill was passed by the Italian Chamber of Deputies but it was not dealt with in time by the Senate in 2017. It included a strengthening of the ius soli and ius culturae principles in the Italian legislation and did not provide for any restriction on dual citizenship in the case of the acquisition of Italian citizenship via ius culturae or the conditional ius soli.

Under the current law of 1992, dual citizenship is not excluded either but, given the low number of naturalisations, remains a relatively marginal side-effect of the possibility of granting citizenship to foreigners in certain cases. However, the issue of multiple citizenship may well gain greater salience when the debate on a reform of Italian citizenship law under the new aspect of immigration is resumed.

\section{Conclusions}

The normative reference point for Italian citizenship today is Law No. 91/1992, which regulates the acquisition of Italian citizenship through ius sanguinis and, in only a few exceptional cases, also through ius soli. This law was already an anachronism when it 
was passed, especially since the international trend has long since moved in a different direction (Baraggia 2017). Moreover, after the Second World War, especially in the 1960s, Italy had undergone a process of radical social transformation and, from the 1970s onwards, had been transformed from a country of emigration into a country of immigration.

It was the massive emigration since the second half of the nineteenth century that led to Italy's first organic citizenship law of 1912, which strengthened the ties with its emigrants through ius sanguinis. However, at the same time, Italy could not avoid allowing dual citizenship as an option through the ethno-cultural back door for these "Italians abroad". The 1992 law adopted the logic of the 1912 law, even though the social framework had changed completely.

The historical-political and legal analysis of dual citizenship in Italy confirms, lastly, the statement formulated at the beginning of this chapter - that questions of emigration and immigration have essentially shaped and continue to shape the attitude of Italy towards dual citizenship. A special case is that of citizens of Italian nationality who, as a result of war, live in states whose territories were formerly part of Italy - specifically, Italians in Slovenia and Croatia. Over the past 30 years there has been an increasing tendency towards the "ethnicisation" of the concept of the nation state, which is not unique in Europe and which has also had a strong influence on the debate on granting citizenship to foreigners, as well as on the debate on dual citizenship. At the same time, the granting of citizenship to ethnic minorities by kin states has shown that the decisive factor here is not so much international norms as international power relations.

In all these issues, the Italian legislator has always been ambivalent and contradictory. Based on the ethno-cultural narrative of its own nation, Italy has always pursued an inclusive policy towards Italian emigrants but an exclusionary tendency towards immigrants. Depending on the political orientation of the government, the "ethnic model" of the centre-right governments with its ethnic colouring of ius sanguinis contrasts with an integration model promoted by the centre-left governments who, today, support ius culturae and ius soli. If the latter proposals were adopted, they would open up access to dual citizenship to large groups of first and second generations of immigrant origin that are currently confined to a status as foreigners.

\section{References}

Albani, M. and Pittau, F. 2017. L'emigrazione degli italiani: dai picchi del dopoguerra ai nuovi flussi, Dialoghi Mediterranei, 1 July. Available at: http://www.istitutoeuroarabo.it/ DM/lemigrazione-degli-italiani-dai-picchi-del-dopoguerra-ai-nuovi-flussi/ (accessed 30 November 2020).

Associazione Internet degli Emigrati Italiani (ed.) 2019. II più grande esodo della storia moderna. Available at: http://www.emigrati.it/Emigrazione/Esodo.asp (accessed 30 November 2020). 
Baraggia, A. 2017. La cittadinanza "composita" in alcune esperienze europee. Spunti di riflessione per il caso italiano, federalismi.it, 18. Available at: https://www.federalismi.it/nv14/articolo-documento.cfm?Artid=34823\&content=La\%2Bcittadinanza\%2B\%27composita\%27\%2Bin\%2Balcune\%2Besperienze\%2Beuropee\&content_. author=\%3Cb\%3EAntonia\%2BBaraggia\%3C\%2Fb\%3E (accessed 30 November 2020).

Bollati, G. 2011. L'Italiano. I/ Carattere Nazionale come Storia e come Invenzione. Turin: Einaudi.

Camera dei Deputati 2002. Proposta di legge N. 3208. Available at: http://leg14.camera.it/_ dati/leg14/lavori/stampati/sk3500/frontesp/3208.htm (accessed 30 November 2020).

Camera dei Deputati 2004. Proposta di legge N. 5199. Available at: http://leg14.camera. it/_dati/leg14/lavori/schedela/apriTelecomando.asp?codice=14PDL0063610 (accessed 30 November 2020).

Camera dei Deputati 2008. Allegato B. Seduta n. 104 del 15/12/2008, Risposta del Sottosegretario di Stato per gli affari esteri: Alfredo Mantica, 14-16. Available at: http://documenti.camera.it/Leg16/resoconti/assemblea/html/sed0104/btris.htm (accessed 30 November 2020).

Camera dei Deputati 2020. Mirko Tremaglia. Available at: https://storia.camera.it/deputato/pierantonio-mirko-tremaglia-19261117/atti?anno=2001\#nav (accessed 30 November 2020).

Camilli, A. 2017. Ius soli, ius sanguinis, ius culturae: tutto sulla riforma della cittadinanza, Internazionale, 20 October. Available at: https://www.internazionale.it/notizie/annalisa-camilli/2017/10/20/riforma-cittadinanza-da-sapere (accessed 30 November 2020).

Carmagnani, M. and Pastore, F. (eds) 2018. Migrazioni e Integrazione in Italia tra Continuità e Cambiamento. Turin: Fondazione Luigi Einaudi.

Ciocca, F. 2019. Diventare italiani per sangue: la cittadinanza per discendenza, Lenius, 19 June. Available at: https://www.lenius.it/cittadinanza-per-discendenza/ (accessed 30 November 2020).

Circolare 2001. Circolare del Ministero dell'Interno n. K. 78 del 24 dicembre 2001. Disposizioni per il riconoscimento della cittadinanza italiana alle persone nate e già residenti in territori appartenuti all'Impero austro - ungarico ed ai loro discendenti. Available at: http://www.immigrazione.biz/circolare.php?id=206 (accessed 30 November 2020).

Circolare 2006. Circolare del Ministero dell'Interno n. K.60.1 del 22.5.2006. Modifiche alla legge 5 febbraio 1992 n. 91, concernenti il riconoscimento della cittadinanza italiana ai connazionali dell'Istria, di Fiume e della Dalmazia e ai loro discendenti. Available at: http://www.immigrazione.biz/circolare.php?id=108 (accessed 30 November 2020).

Circolare 2009. Circolare del Ministero dell'Interno n. 14232 del 28 ottobre 2009. Convenzione sulla riduzione dei casi di cittadinanza plurima e sugli obblighi militari in caso di cittadinanza plurima firmata a Strasburgo il 6 maggio 1963. Denuncia parziale dell'Italia. Available at: http://www.meltingpot.org/Circolare-del-Ministero-dell-Interno-n14232-del-28-ottobre.html (accessed 30 November 2020). 
Colombo, F. 2019. Quanti sono, in tutto, gli stranieri in Italia? Lenius, 04 December. Available at: https://www.lenius.it/stranieri-in-italia/ (accessed 30 November 2020).

Colucci, M. 2018. Storia dell'Immigrazione Straniera in Italia. Dal 1945 ai Giorni Nostri. Rome: Carocci.

Council of Europe 1963. Convention on the Reduction of Cases of Multiple Nationality and on Military Obligations in Cases of Multiple Nationality, Strasbourg, 6.V.1963. Strasbourg: Council of Europe. Available at: https://www.coe.int/de/web/conventions/full-list/-/ conventions/rms/090000168006b659 (accessed 30 November 2020).

Council of Europe 1997. European Convention on Nationality (European Treaty Series No. 166). Strasbourg: Council of Europe. Available at: https://www.coe.int/en/web/ conventions/full-list/-/conventions/rms/090000168007f2c8 (accessed 30 November 2020).

Denicolò, G. and Pallaver, G. 2018. Doppelstaatsbürgerschaft für Südtiroler/-innen: Verzicht auf Alleingänge, in Alber, E., Engl, A. and Pallaver, G. (eds) Politika 2018. Südtiroler Jahrbuch für Politik/Annuario di politica dell'Alto Adige/Anuar de politica dl Südtirol. Bozen: Edition Raetia, 255-280.

Diodato, E. 2020. Chi sono e quanti sono gli immigrati irregolari?, PiuCulture. I/ giornale dell'intercultura a Roma, 13 May. Available at: https://www.piuculture.it/2020/05/ chi-sono-e-quanti-sono-gli-immigrati-irregolari-dati/ (accessed 30 November 2020).

DPR 1993. Decreto del Presidente della Repubblica 12 ottobre 1993, n. 572. Regolamento di esecuzione della legge 5 febbraio 1992, n. 91, recante nuove norme sulla cittadinanza. Available at: https://www.normattiva.it/uri-res/N2Ls?urn:nir:stato:decreto.del.presidente.della. repubblica:1993-10-12;572!vig (accessed 30 November 2020).

DPR 1994. Decreto del Presidente della Repubblica 18 aprile 1994, n. 362. Regolamento recante disciplina dei procedimenti di acquisto della cittadinanza italiana. Available at: https://www.gazzettaufficiale.it/eli/id/1994/06/13/094G0368/sg (accessed 30 November 2020).

Fondazione Migrantes (ed.) 2019. Rapporto Italiani nel Mondo 2019. Todi: Tau Editrice.

Forlati, S. 2019. "Ius soli", "ius culturae" e diritto internazionale, Diritti umani e diritto internazionale, 1(January-April): 69-84.

F.Q. 2019. Italiani all'estero: oggi sono più di 5 milioni. E se ne vanno anche famiglie e anziani, II Fatto Quotidiano, 07 February. Available at: https://www.ilfattoquotidiano. it/2019/02/07/italiani-allestero-dati-aire-oggi-sono-piu-di-5-milioni-e-se-ne-vannoanche-famiglie-e-anziani/4954545/ (accessed 30 November 2020).

Ginsborg, P. 1998. L'Italia del Tempo Presente. Famiglia, Società Civile, Stato 1980-1996. Turin: Einaudi.

Haller, M., Raup, G. and Ressler, R. 2009. National identity in comparative perspective, in Haller, M., Jowell, R. and Smith, T.W. (eds) The International Social Survey Programme, 1984-2009. Charting the Globe. London and New York: Routledge, 223-241.

Kochenov, D. 2019. Citizenship. Boston: MIT Press. 
Legge 1912. Legge 13 giugno 1912, n. 555 sulla cittadinanza italiana. Available at: http:// amblima.esteri.it/resource/2007/03/12736_f_amb61Legge13giugno1912n_555sullacittadinanzaitaliana.htm (accessed 30 November 2020).

Legge 1986. Legge 21.4.1986 n. 180. Modificazioni dell'art. 5 della legge 21.4.1983 n. 123 recante disposizioni in materia di cittadinanza. Available at: https://www.gazzettaufficiale.it/eli/id/1986/05/17/086U0180/sg (accessed 30 November 2020).

Legge 1992. Legge 5 febbraio 1992, n. 91. Nuove norme sulla cittadinanza (GU Serie Generale n.38 del 15-02-1992), entrata in vigore: 16-8-1992. Available at: https://www.gazzettaufficiale.it/eli/id/1992/02/15/092G0162/sg (accessed 30 November 2020).

Legge 2000. Disposizioni per il riconoscimento della cittadinanza italiana alle persone nate e già residenti nei territori appartenuti all'Impero austro-ungarico e ai loro discendenti. Available at: http://www.parlamento.it/parlam/leggi/00379l.htm (accessed 30 November 2020).

Legge 2001. Norme per l'esercizio del diritto di voto dei cittadini italiani residenti all'estero (GU n.4 del 5-1-2002), legge 27 dicembre 2001, n. 459, Testo in vigore dal:6-1-2002. Available at: https://www.normattiva.it/uri-res/N2Ls?urn:nir:stato:legge:2001-12-27;459!vig (accessed 30 November 2020).

Legge 2006. Modifiche alla legge 5 febbraio n. 92 del 1991, concernenti le disposizioni per il riconoscimento della cittadinanza italiana ai connazionali dell'Istria, di Fiume e della Dalmazia ed ai loro discendenti. Available at: https://www.camera.it/parlam/leggi/06124l. htm (accessed 30 November 2020).

Legge 2009. Disposizioni in materia di sicurezza pubblica, Legge 15 luglio 2009, n. 94. Available at: http://www.parlamento.it/parlam/leggi/09094l.htm (accessed 30 November 2020).

Liberto, V. 2018. "Il passaporto sotto al cuscino." Come hanno ottenuto la "doppia cittadinanza" gli italiani di Slovenia e Croazia - e perché? Intervista a Maurizio Tremul, esponente della minoranza italiana in Istria, salto.bz., 25 January. Available at: https://www.salto.bz/de/article/24012018/il-passaporto-sotto-al-cuscino (accessed 30 November 2020).

Lüsebrink, H.-J. 2009. L'Etat-Nation/Staatsnation. Zur frühmodernen Genese und postmodernen Infragestellung des Nationalen, in Hudemann, R. and Schmeling, M. (eds) Die "Nation" auf dem Prüfstand/La "Nation" en Question/Questioning the "Nation". Berlin: Akademie Verlag, 3-16.

Mancino, D. 2019. Gli italiani all'estero: quanti sono, dove sono andati e quando sono partiti, II sole24 ore, 15 November. Available at: https://www.infodata.ilsole24ore. com/2019/11/15/gli-italiani-allestero/?refresh_ce=1 (accessed 30 November 2020).

Marro, E. 2019. Sorpresa: I'emigrazione italiana all'estero sta svuotando il Centro-Nord, non il Sud, I/ sole24ore, 11 May. Available at: https://www.ilsole24ore.com/art/sorpresa-I-emigrazione-italiana-all-estero-sta-svuotando-centro-nord-non-sud-ACVgAC (accessed 30 November 2020). 
Martocchia, A. 2009. Terre irredente in Coordinamento Nazionale per la Jugoslavia/Italijanska Koordinacija za Jugoslaviu. Available at: CNJ / Terre irredente (accessed 06 December 2020).

Ministero degli Affari Esteri e della Cooperazione Internazionale 2012. Intervento del Ministro Terzi alla Cerimonia di commemorazione di Mirko Tremaglia. Rome: Ministero degli Affari Esteri. Available at: https://www.esteri.it/mae/it/sala_stampa/interventi/20120131_comtrem.html (accessed 30 November 2020).

Ministero degli Affari Esteri e della Cooperazione Internazionale 2019. Cittadinanza. Rome: Ministero degli Affari Esteri. Available at: https://www.esteri.it/mae/it/servizi/ italiani-all-estero/cittadinanza.html (accessed 30 November 2020).

Ministero degli Affari Esteri e della Cooperazione Internazionale 2020a. Anagrafe Italiani residenti all'estero (A.I.R.E.). Rome: Ministero degli Affari Esteri. Available at: https:// www.esteri.it/mae/it/servizi/italiani-all-estero/aire_0.html (accessed 30 November 2020).

Ministero degli Affari Esteri e della Cooperazione Internazionale 2020b. Direzione Generale per gli italiani all'estero e le politiche migratorie. Rome: Ministero degli Affari Esteri. Available at: https://www.esteri.it/mae/it/ministero/struttura/dgitalianiestero/(accessed 30 November 2020).

Ministero degli Affari Esteri e della Cooperazione Internazionale 2020c. Comites. Rome: Ministero degli Affari Esteri. Available at: https://www.esteri.it/mae/it/servizi/italiani-all-estero/organismirappresentativi/comites.html (accessed 30 November 2020). Ministero del Lavoro e delle Politiche Sociali 2019a. IX Rapporto Annuale. Gli Stranieri nel Mercato del Lavoro in Italia. Rome: Anpal Servizi.

Ministero del Lavoro e delle Politiche Sociali 2019b: Permesso di soggiorno Ue per lungo soggiornanti. Available at: http://www.integrazionemigranti.gov.it/normativa/procedureitalia/Pagine/PERMESSO-DI-SOGGIORNO-CE-PER-LUNGO-SOGGIORNANTI.aspx (accessed 30 November 2020).

OSCE 2008. The Bolzano/Bozen Recommendations on National Minorities in Inter-State Relations. Vienna: Organization for Security and Co-operation in Europe. Available at: https://www.osce.org/hcnm/bolzano-bozen-recommendations (accessed 30 November 2020).

Osimo Treaty 1975. No. 24848. ITALY and YUGOSLAVIA. Treaty on the Delimitation of the Frontier for the Part not Indicated as such in the Peace Treaty of 10 February 1947 (with Annexes, Exchanges of Letters and Final Act). Signed at Osimo, Ancona, on 10 November 1975. Available at: https://www.fomoso.org/wp-content/uploads/2018/07/Osimo-Treaty-1975.pdf (accessed 30 November 2020).

Palermo, F. 2020. "Doppio passaporto": uno sguardo comparato e qualche riflessione sulle misure di promozione di minoranze residenti all'estero, in Pallaver, G., Alber, E. and Engl, A. (eds) Politika 2020. Südtiroler Jahrbuch für Politik/Annuario di Politica dell'Alto Adige/Anuar de Politica dl Südtirol. Bozen: Edition Raetia, 205-226. 
Patriarca, S. 2010. Italianità. La Costruzione del Carattere Nazionale. Rome and Bari: Laterza. Peace Treaty 1947. Treaty of Peace with Italy. Available at: https://reparations.qub.ac.uk/ assets/uploads/m-ust000004-0311.pdf (accessed 30 November 2020).

Peterlini, O. 2019. Ein Pass für Nachfahren österreichischer Staatsbürger. Statt ethnischer Trennung eine historische Lösung nach dem Muster der Italiener im Ausland, Europa Ethnica, 1(2): 23-31.

Pupo, R. and Spazzali, R. 2003. Foibe. Milan: Bruno Mondadori Editori.

Rosoli, G. 1978. Un Secolo di Emigrazione Italiana 1876-1976. Rome: Cser.

Senato della Repubblica 2015. Disegno di legge: Modifiche alla legge 5 febbraio 1992, $n$. 91, e altre disposizioni in materia di cittadinanza. Available at: https://www.senato.it/ leg/17/BGT/Schede/Ddliter/46079.htm (accessed 30 November 2020).

Senato della Repubblica 2020. I dossier di documentazione: Servizio Studi. Available at: https://www.senato.it/documentazione_studi (accessed 30 November 2020).

Trattato di Pace 1947. Trattato di Pace 1947 fra l'Italia e le Potenze Alleate ed Associate. Available at: https://it.wikisource.org/wiki/Trattato_di_pace_fra_l\%27ltalia_e_le_Potenze_Alleate_ed_Associate_-_Parigi,_10_febbraio_1947 (accessed 30 November 2020).

Trattato 1977. Trattato tra la Repubblica Italiana e la Repubblica Socialista Federativa di Jugoslavia, Supplemento ordinario alla Gazzetta Ufficiale n. 77 del 21 marzo 1977. Trieste and Gorizia: Unione Culturale Economica Slovena. Available at: http://www.skgz.org/ it/trattato-tra-la-repubblica-italiana-e-la-repubblica-socialista-federativa-di-jugoslavia (Accessed 30 November 2020).

Tullio-Altan, C. 1999. Gli Italiani in Europa. Bologna: II Mulino.

Tuttitalia 2019. Cittadini stranieri in Italia: 2019. Available at: https://www.tuttitalia.it/ statistiche/cittadini-stranieri-2019/ (accessed 30 November 2020).

UNICEF 2019. Minorenni di Origine Straniera. Available at: https://www.unicef.it/doc/7701/ la-proposta-di-riforma-della-legge-sulla-cittadinanza-ddl-s-2092-un-decalogo-sullo-ius-soli-temperato.htm (accessed 30 November 2020).

Wörsdorfer, R. 2009. II Confine Orientale. Bologna: Il Mulino.

Zincone, G. 2010. Citizenship Policy Making in Mediterranean EU States. Florence: European University Institute, Robert Schuman Centre for Advanced Studies. 



\section{Austrian Citizenship at Home and Abroad}





\title{
Chapter 10
}

\section{Non-Toleration of Dual Citizenship in Austria}

\author{
Rainer Bauböck, European University Institute, Florence \\ Gerd Valchars, University of Vienna
}

\begin{abstract}
This chapter addresses the puzzle of why Austria has resisted the global trend towards the toleration of dual citizenship, even though none of the common explanations for such resistance apply to the Austrian case. We start by examining the history of Austrian citizenship law and the international conventions that Austria has joined. We then present a detailed analysis of those provisions in Austrian law that are relevant for dual citizenship. We find that Austria has accepted dual citizenship in the case of acquisition by birth but still clings to a general prohibition of dual citizenship in both the naturalisation of immigrants and when Austrians voluntarily acquire another citizenship. We suggest that politicised hostility towards dual citizenship for one particular group of immigrants those from Turkey - seems to have blocked debates about reform. The chapter ends with the sketching of pathways to policy change and a menu of legislative reforms building on principles - already recognised in Austrian citizenship legislation - that could lead to the toleration of dual citizenship.
\end{abstract}

\section{Introduction}

Other chapters in this book have shown that the increasing toleration of dual citizenship is a strong global trend (see Spiro's Chapter 4 and Harpaz' Chapter 5). Chapter 3 (by Bauböck) examined its limits. One of the hypotheses explored there is that certain developing states like China and India resist this trend if they remain obsessed about national sovereignty and security. A second factor triggering resistance to dual citizenship are threats by neighbouring states that claim powers to protect ethnic kin minorities outside their borders. In a third category of cases, the non-toleration of dual citizenship may be a result of policy inertia. If a country has not been exposed to recent large emigration or immigration flows or if it has entrenched a prohibition of dual citizenship in its constitution, then it is more likely that its citizenship laws will remain shaped by a now-defunct principle of international law that dual citizenship is to be avoided.

Austria belongs to the just 18 per cent of countries worldwide that do not tolerate dual citizenship either in outgoing naturalisations (i.e. for Austrians voluntarily acquiring another citizenship) or incoming naturalisations (i.e. for naturalisation applicants in Austria who have to renounce all previous citizenships - see Chapter 3 in this volume). 
Although there are exceptions, Austria seems to be stricter in this regard than comparable European countries that also cling to symmetric non-toleration. For example, in Germany and the Netherlands, dual citizenship is currently accepted in more than 60 per cent of all incoming naturalisations (Mediendienst Integration 2019; Chapter 6 by Peters and Vink, in this volume).

The case of Austria is a curious one. Austria pooled much of its national sovereignty with other states when joining the European Union in 1995. It has experienced large-scale emigration throughout its modern history and has become one of Europe's foremost immigration states in terms of numbers of foreign-born populations and residents without national citizenship. Austria's citizenship law has become highly politicised since the late 1990s and has since undergone many amendments. The federal constitution also does not spell out any principles for the acquisition and loss of citizenship that would constrain the toleration of dual citizenship. Finally, kin states of Austria's officially recognised ethnolinguistic minorities (Czechia, Slovakia, Hungary, Slovenia and Croatia) have not offered dual citizenship to these populations, whereas the Austrian government of 2017-2019 considered such an option for German-speakers in the Italian province of South Tyrol/Alto Adige. Austrian resistance against dual citizenship therefore does not fit any of the general explanations listed above and remains deeply puzzling. We suggest a few contextual explanations as well as scenarios for change in the concluding section of this chapter. Before doing so, however, we explore the history of Austria's attitudes toward plural nationality and examine in detail the provisions of Austrian citizenship law that aim to prevent dual citizenship as well as the exceptions where the law fails to do so.

In this chapter, we distinguish between three basic ways that dual citizenship can be generated:

- by birth (through the combination of ius soli and ius sanguinis or through the attribution of citizenship iure sanguinis from two parents with different nationalities);

- through incoming naturalisations (when the state whose citizenship is acquired does not require or enforce renunciation of a previous citizenship); and

- in outgoing naturalisations (if a currently held citizenship is not lost when a new citizenship is acquired).

\section{Dual citizenship in Austrian history: domestic and international law}

The first legal provisions concerning the acquisition and loss of Austrian citizenship date back to 1812 and 1832 respectively. ${ }^{1}$ These laws were legally valid only in the Austrian part of the Austrian Empire - in Hungary, only some parts of these laws had legal force between 1851 and 1861 (Baumruck 2013; Thienel 1989/1990). According to these provisions,

1 Articles 28-32 Allgemeines Bürgerliches Gesetzbuch (ABGB), JGS 1811/946 (Civil Code); Auswanderungspatent, JGS 1832/2557 (Edict of Emigration). 
non-nationals automatically acquired Austrian citizenship through naturalisation after ten years of residence, by joining the public service or starting a trade. In addition, when fulfilling some naturalisation criteria, citizenship could also be bestowed on applicants as an "act of grace" (Buschmann 1833; Thienel 1989/1990). Automatic naturalisation after ten years of residence, enforced also against the will of the person concerned, caused diplomatic conflicts. It was therefore changed in 1833 from automatic acquisition to naturalisation after application, with ten years as the minimum residence requirement (Buschmann 1833; Thienel 1989/1990). In all these cases, dual citizenship was fully accepted and a renunciation of previously held citizenships was not necessary (Buschmann 1833; Thienel 1989/1990). Only later were several bilateral agreements signed (inter alia in 1864 with Prussia) in which the states mutually agreed to accept naturalisations by nationals of the respective other state only after renunciation of the previous citizenship (Thienel 1989/1990).

The same applied to Hungarian nationals after the so-called Austro-Hungarian Compromise of 1867, which established the dual monarchy of Austria-Hungary and divided the two former parts of the Austrian Empire into semi-sovereign entities within one union. As a general rule, citizens of the former Austrian Empire acquired either Austrian or Hungarian citizenship depending on the part of the Empire from which their local citizenship (Heimatrecht) originated. Naturalisations of Hungarians in Austria were possible but, in this case, renunciation of the previously held citizenship was necessary (Thienel 1989/1990).

Austrian citizenship, furthermore, was automatically acquired by the marriage of a non-national woman to an Austrian man (but not in the converse case of a non-national man married to an Austrian woman; in this case the marriage led to the loss of Austrian citizenship) and iure sanguinis by birth. Children born in wedlock acquired Austrian citizenship if the father was an Austrian national; children born out of wedlock became Austrian nationals only if the mother held Austrian citizenship (Buschmann 1833; Thienel 1989/1990).

At the same time, Austrian citizenship was lost as a consequence of emigration. Acquiring foreign citizenship per se did not cause such a loss. Only naturalisation together with emigration led to expatriation (Thienel 1989/1990). In 1870, Austria-Hungary and the United States signed a bilateral treaty ${ }^{2}$ to reciprocally recognise naturalisations of their own citizens upon five years of residence in the other state. ${ }^{3}$ As the acquisition of a

2 These nineteenth-century citizenship agreements between the USA and European states are usually referred to as the Bancroft Treaties (see Chapter 2 by Spiro).

3 Staatsvertrag vom 20. September 1870 mit den vereinigten Staaten von Amerika wegen Regelung der Staatsbürgerschaft der aus der österreichischen Monarchie nach den vereinigten Staaten von Amerika und aus diesen nach Österreich-Ungarn auswandernden gegenseitigen Staatsangehörigen, RGBI 1871/74 (State Treaty of 20 September 1870 with the United States of America regulating the citizenship of mutual nationals who emigrated from the Austrian monarchy to the United States of America and from these to Austria-Hungary). 
foreign nationality after emigration in any case led to expatriation according to Austrian law at the time the agreement was signed and ratified, its practical impact is not evident.

Taking these first legal provisions on Austrian citizenship together, one can conclude that dual citizenship as a consequence of incoming naturalisation was, initially, completely accepted and later limited through bilateral agreements. The loss of citizenship due to emigration prevented dual citizenship in cases of outgoing naturalisation and the regulations concerning acquisition by marriage and by birth completely eliminated dual citizenship by birth.

During the last decades of the Habsburg monarchy, some details of the legal provisions concerning the acquisition and loss of Austrian nationality were modified several times but the law remained constant with regard to the occurrence of dual citizenship. After the end of the First World War and the collapse of the Austro-Hungarian monarchy in 1918 , the first law governing citizenship of the new republic, passed in $1925,{ }^{4}$ maintained broad continuity. The acquisition of citizenship by birth and by marriage remained the same. However, with regards to incoming naturalisations, the renunciation of previously held citizenships became the general rule for the first time and dual citizenship was exceptionally tolerated only if it was accepted by the country of origin too. The same regulation can still be found years later in the law passed in 1949 but was interpreted by the Administrative Court in 1965 in a very restrictive way and contrary to the letter of the law. The Court argued for the toleration of dual citizenship only if renunciation of a previous citizenship was legally impossible or possible only under difficult conditions for the individual concerned (Thienel 1989/1990). In the same year, this interpretation eventually became law with the new Citizenship Law of $1965 .{ }^{5}$

As far as outgoing naturalisations were concerned, the law of 1925 also built on previous provisions. Acquiring foreign citizenship led to expatriation; however, the right to retain Austrian nationality could be granted by the provincial government and with the federal chancellor's consent (Thienel 1989/1990). Again, the same regulation pops up in the law of 1949 but here it is the Minister of the Interior, together with the Federal Chancellor, who are able to grant the right to retain citizenship for "solid reasons" (Thienel 1989/1990).

In 1965, several changes were finally introduced in order to eliminate the discrimination of women in citizenship matters (triggered by the intention to adopt the 1957 UN Convention on the Status of Married Women, ${ }^{6}$ ratified by Austria in 1968). The automatic

4 Bundesgesetz vom 30. Juli 1925 über den Erwerb und den Verlust der Landes- und Bundesbürgerschaft, BGBI. 285/1925 (Federal Law of 30 July 1925 on the acquisition and loss of federal and provincial citizenship).

5 Staatsbürgerschaftsgesetz 1965, BGBI. 250/1965 (Citizenship Law of 1965).

6 Convention on the Nationality of Married Women, United Nations, Treaty Series, vol. 309, p. 65, BGBI. 238/1968. 
loss of Austrian citizenship by marriage to a foreign male national was abolished and the automatic acquisition of citizenship by marriage to a male Austrian national was transformed into a right to naturalisation by declaration (Neuwirth 2015). ${ }^{7}$ Multinational marriage was thus legally accepted for the first time, while individual multiple nationalities of the spouses remained taboo.

The adoption of the UN Convention against the discrimination of women ${ }^{8}$ (signed by Austria in 1980 and ratified in 1982) made it necessary to reform the acquisition of citizenship by birth. With the amendment of 1983, the gender-discriminating rule for its acquisition by children born in wedlock was eliminated. Since then, children born in wedlock acquire Austrian citizenship by birth if one of the parents is an Austrian national (Neuwirth 2015); the occurrence of dual citizenship was explicitly accepted (Thienel 1989/1990). However, the acquisition by birth for children born out of wedlock still remained limited to ius sanguinis a matre. It was not until 2013 that the law was accordingly amended after a ruling by the Constitutional Court (Stern and Valchars 2013).

Since World War II, international legal norms against the discrimination of women have thus been a major force pushing for the acceptance of dual citizenship in Austria but, at the same time, Austria joined efforts in international law which aimed at constraining this change. Besides the above-mentioned bilateral agreements on naturalisation and the renunciation of the previous citizenship - such as that with Prussia from 1864, followed by agreements with the German Empire and, several years later, with Czechoslovakia (1920/21) and Italy (Thienel 1989/1990) and the Bancroft Treaty of 1870/71 with the USA - Austria was one of the signatory states of the Hague Convention ${ }^{9}$ in 1930, although the country never ratified it. In the convention's preamble, the contracting states famously agreed that "every person should have a nationality and should have one nationality only" and hence aimed for "the abolition of all cases both of statelessness and of double nationality".

Austria was also one of the signatory states of the Strasbourg Convention on multiple nationality ${ }^{10}$ in 1963 (only ratified by parliament in 1975) and by now is (together with the Netherlands) one of the two remaining countries that have not denounced its Chapter I on the reduction of multiple nationality requiring the loss of citizenship upon naturali-

7 In 1983, naturalisation by simple declaration was replaced by a right to naturalisation conditional on fulfilling the general naturalisation requirements (except for a shorter residence criterion) and was, at the same time, extended to include both women and men married to Austrian nationals (Stern and Valchars 2013).

8 Convention on the Elimination of all Forms of Discrimination Against Women, United Nations, Treaty Series, vol. 1249, p. 13, BGBI. 443/1982.

9 Convention on Certain Questions relating to the Conflict of Nationality Laws, League of Nations, Treaty Series, vol. 179, p. 89, No. 4137.

10 Convention on the Reduction of Cases of Multiple Nationality and on Military Obligations in Cases of Multiple Nationality, ETS No. 043, BGBI. 471/1975. 
sation in another signatory state. ${ }^{11}$ The Strasbourg Convention is sometimes mentioned by the Austrian government and some legal scholars ${ }^{12}$ as a reason why Austria is obliged under international law to maintain its strict policy of non-toleration of dual citizenship. However, as an international agreement, the convention's provisions of preventing dual nationality apply only between those states adhering to them. Since 01 January 2020, when Norway's denunciation of Chapter I became effective, the convention only obliges Austria to withdraw its citizenship from Austrians voluntarily acquiring Dutch citizenship and, conversely, obliges the Netherlands to do the same for its nationals who become Austrians by naturalisation. The convention therefore leaves Austria free to tolerate or not tolerate dual citizenship in relation to all other states.

Finally, Austria also joined the European Convention on Nationality or ECN ${ }^{13}$ (signed in 1997, ratified in 2000). Unlike the Hague and the Strasbourg Conventions, the ECN does not aim to abolish or even just to reduce multiple nationality but instead provides solutions to its consequences and further acknowledges the states' varied approaches to this question, leaving it up to them whether or not to accept multiple nationality as a consequence of naturalisations. More importantly, Article 14 of the ECN explicitly requires its member states to allow children who have acquired different nationalities automatically at birth and spouses who have automatically been naturalised through marriage to retain these nationalities. Austria did not have to change its law in these respects, since the automatic acquisition through marriage had been abolished in 1965 and gender-neutral ius sanguinis (for children born in wedlock) was introduced in 1983. However, in these cases the explicit recognition of dual citizenship in a major international treaty made it clear that the general principle of avoidance had been abandoned.

\section{Austrian citizenship law and its effects on dual citizenship ${ }^{14}$}

\subsection{Dual citizenship by birth}

There is a long tradition of citizenship iure sanguinis by birth in Austria, going back to the earliest citizenship laws. However, as mentioned above, for a long time ius sanguinis provisions were limited to children born in wedlock to Austrian fathers and to children of Austrian mothers born out of wedlock. Unconditional ius sanguinis a matre and a patre were not completed in Austria until 2013. Even today, there is a notable restriction: if born out of wedlock, a child will be an Austrian by birth only if the Austrian father recognises

11 https://www.coe.int/en/web/conventions/full-list/-/conventions/treaty/043/signatures (accessed 20 June 2020)

12 See e.g. Obwexer (2018), who argues that Austria would have to denounce the Strasbourg Convention before offering dual citizenship to German-speaking Italians living in South Tyrol/ Alto Adige.

13 European Convention on Nationality, ETS No. 166, BGBI. III 39/2000.

14 Staatsbürgerschaftsgesetz 1985, BGBI. 311/1985 idF BGBI. I 146/2020 (Citizenship Law of 1985). 
the child within eight weeks of his or her birth. Otherwise and for children born before 2013, a special form of facilitated naturalisation is available: if they live in Austria and are younger than 14 years, they can apply for Austrian citizenship by naturalisation. Unlike for regular naturalisation, in this case the renunciation of other citizenships is not required.

Children under the age of six months found on the territory of the republic are considered to be Austrian nationals by descent, although only until proof to the contrary. Persons who are born in Austria and have been stateless since birth may apply for Austrian citizenship between the ages of 18 and 20. The naturalisation requirements in this case are ten years of residence (five years of them uninterrupted immediately before the application); applicants must not have been convicted for criminal acts that threaten national security but must demonstrate sufficient knowledge of the German language and pass the naturalisation test (Ecker 2017).

lure sanguinis acquisition by children born abroad is not subject to any restrictions. Austrian citizenship may be indefinitely attributed to the descendants of Austrian emigrants. This intergenerational transmission will only be prevented if parents of Austrian origin have renounced their Austrian citizenship before the birth of the child in order to acquire the citizenship of another country. Unlike other states, which interrupt the transmission of extraterritorial citizenship at birth after the first generation born abroad, Austria does so indirectly through its prohibition of dual citizenship for expats.

The native-born children of foreign nationals may apply for facilitated naturalisation after six years of legal residence in Austria. In this case, the general requirements for ordinary naturalisation - including the renunciation of previous citizenships - apply, although proof of German-language knowledge and the naturalisation test can be waived. More than one third of all yearly naturalisations in Austria (2019: 35.1 per cent; 2002-2019: 33.9 per cent $)^{15}$ are those of applicants born in Austria.

Hence dual citizenship by birth is fully accepted in Austria and may occur as a consequence of bi- or multinational parentage or of the iure sanguinis acquisition of Austrian citizenship abroad in a country with ius soli provisions. In both cases, multiple citizenships may be held permanently; there are no obligations to opt for only one of the citizenships acquired at birth. In the case of early naturalisation for children born in Austria on the other hand, the usual renunciation requirement for ordinary naturalisation applies. Dual citizenship is accepted only in the case of the naturalisation of children born out of wedlock to Austrian fathers.

\subsection{Incoming naturalisations}

For incoming naturalisation, the renunciation of previously held citizenships is generally required. The law allows exceptions only in very limited cases. If an applicant is unable

15 STATcube - Statistische Datenbank von Statistik Austria, Berichtsjahr nach Anzahl der Einbürgerungen und Geburtsland (accessed 24 June 2020). 
or cannot reasonably be expected to relinquish the nationality of his or her previous home country, the law allows its retention. Applicants from countries that do not permit renunciation (such as most Arab states and Iran as well as six Latin American states and a few Asian and African ones) can therefore become dual citizens by naturalisation. In addition, extraordinarily high fees for release are mentioned as a concrete reason for exemption since 1998. Recognised refugees were explicitly exempt by law from the renunciation requirement from 1965 until 1998. Since then, they have regularly fallen under the wider exception provision (Stern and Valchars 2013).

If no exemption applies, previously held citizenships must be renounced by applicants either before naturalisation in Austria or within two years thereafter. The normal procedure is that the Austrian authorities issue a guarantee of the grant of Austrian nationality to applicants once the latter fulfil all naturalisation requirements. This guarantee is issued at the end of the naturalisation procedure but before actually granting citizenship. After providing proof that the previous nationality has been relinquished, Austrian citizenship may be acquired. The guarantee is meant to enable applicants to renounce their previous nationalities and is valid for two years (Thienel 1989/1990).

This procedure is highly problematic: between the day on which an individual actually relinquishes his or her previous citizenship and that when Austrian citizenship is finally granted, applicants become, in most cases, temporarily stateless. Moreover, the Austrian guarantee for the acquisition of citizenship is not an unconditional one: it has to be retracted if any of the naturalisation requirements - except for the income requirement ${ }^{16}$ - are no longer met at the time of final acquisition. In other words, after the applicant's renunciation of his or her previous citizenship and before the final granting of the Austrian one, a reassessment of eligibility is needed and naturalisation can be denied. In this case, temporary statelessness becomes permanent. Hence this regulation is considered to violate not only the UN Convention on the Reduction on Statelessness of $1961^{17}$ (signed by Austria in 1972, ratified in 1974) and the ECN but also EU law (de Groot 2020). Currently a preliminary ruling is pending before the Court of Justice of the

16 This exception was introduced in 2013 after the Constitutional Court had annulled the previous provision as unconstitutional (VfGH G 154/10-8, VfSIg. 19.516/2011). The case before the court concerned a woman who had received a guarantee of the grant of Austrian nationality and subsequently renounced her former citizenship. Thereafter she lost her job and no longer fulfilled the sustainable income requirement. She thus became stateless. The Constitutional Court found that statelessness was an unacceptable result - considering that she was not to blame for having lost her job - and therefore annulled the whole paragraph on the revocation of the guarantee; shortly afterwards, however, the legislator reintroduced the provision in its current version (Stern and Valchars 2013).

17 Convention on the Reduction of Statelessness, United Nations, Treaty Series, vol. 989, p. 175, BGBI. 538/1974. Article 7(2) of the convention exceptionally allows for denationalisation based on the assurance of acquiring the nationality of another state. However, in the 2013 Tunis Declaration of the UNHCR on the interpretation of the Declaration, the states agreed that such an 
European Union (CJEU) concerning the revocation of a guarantee which left a former Estonian national permanently stateless. ${ }^{18}$

\section{JY, an Estonian citizen who became stateless while naturalising in Austria}

In 2008, JY - an Estonian citizen living in Austria - applied for Austrian citizenship. In 2014, more than five years later, the Austrian authorities confirmed that she fulfilled all the naturalisation requirements and issued a guarantee of the grant of Austrian nationality on condition of proof that her previous citizenship had been relinquished. In 2015, she subsequently renounced her Estonian citizenship and presented the necessary documents to the authorities. From that moment on, she was stateless.

Twenty months later, in July 2017, the Austrian authorities revoked the guarantee of the grant of Austrian citizenship and rejected her application to naturalise. JY had committed two administrative offences since the acquisition of Austrian citizenship was guaranteed to her: the failure to provide an up-to-date vehicle inspection disk and driving under the influence of alcohol. The administrative fines together amounted to EUR 412. The authorities argued that these offences - in combination with eight prior offences (all concerning speeding, committed between 2007 and 2013, before the guarantee was issued) - made her ineligible for naturalisation. JY no longer met the condition for a clean criminal record. Her temporary statelessness became permanent.

The applicant appealed to the Vienna Administrative Court but the case was dismissed. It is now pending before the Austrian Supreme Administrative Court which, in February 2020, requested a preliminary ruling from the Court of Justice of the European Union (C-118/20 JY v. Wiener Landesregierung). The Austrian court wants to know whether the situation thus described falls within the scope of EU law and, if this is the case, whether the principle of proportionality has to be applied.

In order to prevent statelessness, many countries of origin do not allow for the renunciation of their citizenship before another citizenship has been acquired. Some, therefore, do not release their citizens based on a mere (conditional) guarantee such as that issued by the Austrian authorities. In fact, as a country of origin, Austria itself would not accept a guarantee like the one it issues. Austrian law therefore provides for conditional naturalisation as a second option. In this case Austrian citizenship is being granted upon

assurance must be "unconditional" and may not be "retracted on grounds that conditions for naturalization are not met" (quoted in de Groot 2020).

18 CJEU C-118/20, JY v. Wiener Landesregierung. 
fulfilment of the naturalisation criteria although previously held citizenships have to be renounced within two years. If a newly naturalised Austrian fails to do so and exemptions do not apply, Austrian citizenship has to be revoked again - a revocation which must, however, happen within six years of naturalisation. If the authorities fail to check in time, dual citizenship can be retained.

Besides the exemptions for the renunciation requirement in ordinary naturalisations, further exceptions exist for special naturalisations. Austrian citizenship may be granted if the government confirms that this is in the particular interest of the republic due to the applicant's past and expected outstanding achievements. In this case, regular naturalisation requirements (except for a clean criminal record) and the renunciation of any previous citizenship are waived. As a last remnant of historic practices of automatic naturalisation, until 2008 foreign nationals (and their spouses and children) automatically acquired Austrian citizenship when becoming full professors at an Austrian university; renunciation of a previous citizenship was not required. In 1998 (after Austria joined the European Union in 1995) the provision was changed and henceforth applied to third-country nationals only before being generally abolished in 2008 . Finally, survivors of the Holocaust who had left the country before 1945 due to political persecution (from September 2020 onwards, also their descendants) can now re-acquire Austrian citizenship by notification, again without renouncing their previous citizenship.

Hence, with regards to incoming naturalisation, Austria follows a very strict single nationality policy. In general, the renunciation of a previous citizenship is a precondition for naturalisation and dual citizenship is avoided, even as a temporary status, during the process of change from one nationality to another. The procedural rules even regularly create temporary statelessness (which might become permanent) in order to avoid temporary dual citizenship. Exceptions allowing dual citizenship only exist in very limited cases, in particular when required by international legal norms and when naturalisation is a special interest of the state.

\subsection{Outgoing naturalisations}

In the case of both outgoing and incoming naturalisation, in general Austria does not tolerate dual citizenship. Austrian nationality is lost automatically ex lege by the acquisition of another citizenship if this citizenship had been acquired upon explicit consent. By contrast, automatic naturalisation (e.g. by marriage) does not lead to the loss of Austrian citizenship. This loss is extended to minor children - unless the other parent retains Austrian citizenship - and becomes effective at the very moment when another citizenship is acquired voluntarily. Authorities may only ascertain later by declaratory ruling that Austrian citizenship had already been lost by operation of law (Peyrl 2017a; Thienel 1989/1990). Nevertheless, since the CJEU rulings in the Rottmann case ${ }^{19}$ in 2010

19 CJEU C-135/08, Janko Rottman v Freistaat Bayern, 02 March 2010. 
and, more particularly, in 2019 in the case of Tjebbes and others, ${ }^{20}$ the principle of proportionality has to be applied in cases where the loss of Austrian nationality also leads to the loss of European citizenship (de Groot 2019). ${ }^{21}$

As the loss of Austrian citizenship is automatically triggered by the acquisition of another citizenship, the bilateral exchange of information on naturalisation is crucial in order to administer the Austrian law. The Austrian authorities need to know and interpret the relevant foreign legal provisions on naturalisation - in particular whether, under what circumstances and when exactly citizenship of the respective countries is acquired. Moreover, the Austrian authorities need to be informed about individual naturalisations by Austrian nationals. Article 24 of the ECN provides a legal basis upon which (but no obligation) to share such information. In the 1964 Convention on the exchange of information relating to the acquisition of nationality of the International Commission on Civil Status, ${ }^{22}$ the contracting states agreed to inform each other about any naturalisations of their respective nationals. Bilateral agreements exist between Austria and Germany and Denmark respectively. ${ }^{23}$ However, as dual citizenship is increasingly tolerated, fewer countries actually have an interest in reciprocally sharing such information. ${ }^{24}$ The lack of valid information regarding naturalisation may cause huge problems, as recent developments show (see Section 4).

The retention of Austrian citizenship can exceptionally be permitted if it is in the interest of the republic due to the individual's past and expected achievements or due to grounds deserving particular consideration. If this is considered to be the case, the applicant has to fulfil certain clean criminal-record conditions and the country for whose

20 CJEU C-221/17, M.G. Tjebbes and Others v Minister van Buitenlandse Zaken, 12 March 2019.

21 Following the decision by the CJEU only months later, the Austrian Administrative Court annulled a declaratory ruling by the Austrian authorities ascertaining the loss of Austrian citizenship because of the missing proportionality test (Administrative Court, Ra 2018/01/0477, 30 September 2019).

22 Convention (No. 8) on the exchange of information relating to the acquisition of nationality, International Commission on Civil Status, Paris, 1964.

23 Vereinbarung zwischen der Bundesregierung der Republik Österreich und der Regierung der Bundesrepublik Deutschland über den Austausch von Mitteilungen in Staatsangehörigkeitssachen, BGBI. Nr. 45/1959 idF BGBI. III Nr. 170/2008 (Agreement between the Federal Government of the Republic of Austria and the Government of the Federal Republic of Germany on the exchange of communications in matters of nationality); Vereinbarung zwischen der Österreichischen Bundesregierung und der Königlich Dänischen Regierung über den Austausch von Einbürgerungsmitteilungen, BGBI. Nr. 40/1964 (Agreement between the Austrian Federal Government and the Royal Danish Government on the exchange of naturalisation notifications).

24 Even in 1964, when the convention was originally signed, only ten countries participated. In 2017 (the most recent available information online) only seven countries are still listed as signatory states. Turkey, for example, one of the most important home countries of migrants in Austria, withdrew from the convention in 2010 (http://www.ciec1.org/ [accessed 28 June 2020]). 
citizenship the Austrian national is applying has to consent to the retention (if there are reciprocal arrangements with regards to this question). ${ }^{25}$ Since 1999, the retention of Austrian citizenship also has to be permitted for Austrian nationals by descent on the grounds that the applicant's private and family life deserves particular consideration. Thirdly, since 2007, retention has to be granted if it is in the child's best interests (Peyrl 2017b; Thienel 1989/1990).

These rather vaguely described reasons for retention provided by the law leave the provincial authorities in charge of this matter with wide discretion. This is why some legal scholars consider the provisions on the retention of Austrian citizenship in the interest of the republic to be constitutionally questionable and potentially violating the legality principle (Rieder 2016; Thienel 1989/1990). Interestingly, there are no statistics which show how many retention permits are issued by the Austrian authorities each year and for which reasons. While there are detailed yearly statistics on the acquisition of Austrian citizenship, there is no legal instruction to collect corresponding data on the loss of Austrian citizenship or its retention.

Thus, with regards to incoming and outgoing naturalisations alike, Austria does not, in general, tolerate dual citizenship. However, when comparing the exceptions to the general rule it becomes clear that the regulations on both incoming and outgoing naturalisation are not symmetrical. While, in both instances, the toleration of dual citizenship remains limited to exceptional cases, Austrians by descent naturalising in another state are privileged over any other group. The consequences of a loss of citizenship to their private and family life are recognised by law as reasons to retain it while, in the case of naturalised Austrians acquiring a foreign nationality or of foreign nationals applying for Austrian citizenship, such personal disadvantages do not provide for exceptional retention. This discrimination between Austrians by birth and by naturalisation conflicts with a principle promoted by the European Convention on Nationality: "Each State Party shall be guided by the principle of non-discrimination between its nationals, whether they are nationals by birth or have acquired its nationality subsequently". ${ }^{26}$

\section{Recent debates and scenarios for future changes}

The striking inconsistencies between Austria's policies on dual citizenship have not led to major public controversies or legal challenges. There was, however, an important debate focusing on enforcing the prohibition of dual citizenship for naturalised Austrians in 2018. This concerned one single origin group that has long been stigmatised. Immigrants from Turkey and their children born in Austria are widely considered to be

25 Such a requirement of reciprocal consent can be found only in the 1963 Strasbourg Convention (Annex, pt. 3).

26 European Convention on Nationality, Art. 5 (2). When ratifying the convention, Austria made numerous reservations - but none to Art. 5 
less integrated in socio-economic as well as cultural-linguistic terms and, as a mostly Muslim population, they have been targeted by xenophobic propaganda, especially by the right-wing populist Freedom Party.

The naturalisation rates of immigrants from Turkey were very low until the late 1990s, although guestworkers had arrived already in the late 1960s and large cohorts met the ten-year residence condition from the 1980s. Their numbers increased in the late 1990s and reached a peak in 2003 with 13,680 newly acquiring Austrian citizenship in that year. They declined rapidly thereafter and have remained below 1,000 per year since $2014 .{ }^{27}$ For migrants from Turkey, the requirement to renounce their previous citizenship has been a major obstacle to their naturalisation. Turkey itself had started to abandon restrictions on dual citizenship for its emigrants in 1981. In the 1990s, the Turkish government worried about attacks on Muslims in Germany and provided two options to Turkish citizens who were concerned about having to renounce their citizenship of origin in order to adopt the German one. One was a new status of external quasi-citizenship introduced in 1995, which guaranteed former Turkish nationals readmission to the territory and the right to operate businesses and to inheritance and real-estate property (Kadirbeyoğlu 2012). This so-called "pink card" (later changed to "blue card") was not widely picked up by the Turkish diaspora, apparently because of lingering uncertainty about the consequences of abandoning their formal citizenship status (Çağlar 2004). The other option was a way of circumventing Germany's renunciation requirement, which was perfectly legal until 2000. After renouncing their original citizenship and becoming Germans, former Turkish nationals could easily re-acquire Turkish citizenship through a simple application at a consulate. In response to the mass denationalisation of Jews during the Nazi regime, German law did then not allow a German national residing in Germany to be deprived of his or her citizenship. This so-called Inlandsklausel (domestic territory exemption) was dropped in the general reform of Germany's citizenship law in 1999. Since then, the voluntary re-acquisition of Turkish citizenship has had the consequence of them losing their German one. After the German government stepped up efforts to identify those who had re-acquired Turkish citizenship since 01 January 2000, about 20,000 persons had their German citizenship - and voting rights - nullified prior to the 2005 federal elections (Bauböck 2006).

Under Austrian law, as explained in the previous section, it was never legally possible to re-acquire Turkish citizenship while retaining the Austrian one. It is, however, likely that Turkish consulates also offered the re-acquisition option to newly naturalised Austrians without properly informing those interested about the risks. The case illustrates the fact that the effective prevention of dual citizenship requires cooperation between governments. The Turkish government was, however, neither obliged nor willing to in-

27 STATcube - Statistische Datenbank von Statistik Austria, Berichtsjahr nach Anzahl der Einbürgerungen und bisheriger Staatsbürgerschaft (accessed 24 June 2020). 
form the German or Austrian authorities about who had re-acquired Turkish citizenship. ${ }^{28}$ Circumventing the ban on dual citizenship thus seemed like a loophole that could be safely exploited. However, when the issue became politicised, host-country authorities took action and tried to find documentary evidence.

The issue became salient in 2016 in the wake of demonstrations by Turkish immigrants against the attempted coup in Turkey and resurfaced during the campaigns for the Turkish constitutional referendum in April 2017 and the general elections in June 2018, in each of which the ruling AK Party mobilised the diaspora vote in Austria, Germany and other countries with strong contingents of immigrants from Turkey. Initial interventions by then-Foreign Minister Sebastian Kurz calling for a prohibition of dual citizenship and by the Minister of the Interior Wolfgang Sobotka (both Austrian People's Party, ÖVP) for financial penalties displayed a lack of knowledge of Austrian citizenship law. As explained in Section 3, dual citizenship is not permitted in the relevant cases but nor is voluntarily acquiring a foreign nationality without permission by the authorities a criminal offence either since, in this case, Austrian citizenship is automatically lost by operation of law. In April 2017, Peter Pilz - then a Member of Parliament for the Green Party - and Heinz-Christian Strache, then the leader of the right-wing Freedom Party, revealed that they had come into possession of lists of Turkish citizens who had been registered for voting in elections in Turkey from Austria. They called on the Austrian authorities to identify those on the lists who had obtained Austrian citizenship. On 25 September 2018, Austria's highest administrative court confirmed the loss of Austrian citizenship of a Turkish immigrant naturalised in 1996, based on evidence that his name showed up in the Turkish electoral registry. ${ }^{29}$ On 17 December 2018, however, the Austrian Constitutional Court overruled this judgment, arguing that the alleged electoral registry was insufficient evidence that the person had re-acquired Turkish citizenship since the list had never been confirmed as authentic by the Turkish authorities. The court also objected to the way that the authorities had put the burden of proof for a negative fact - that he was not a Turkish citizen - on the shoulders of the accused..$^{30} \mathrm{~A}$ significant number of cases in which Austrians of Turkish origin have been deprived of their citizenship will now have to be revisited. The episode illustrates how excessive political zeal in fighting against dual citizenship can come into conflict with elementary principles of the rule of law. It also shows the impotency of unilateral action in preventing a status that is created by two states acting independently from each other.

As already demonstrated in the previous section, Austria's attitude is also marked by inconsistencies, since dual citizenship is tolerated in many cases. In principle, one could

28 In 2010, Turkey also left the 1964 Convention on the Exchange of Information Relating to Acquisition of Nationality (see Footnote 24).

29 VwGH Ra 2018/01/0364-5 25. September 2018.

30 VfGH E 3717/2018-42 11. Dezember 2018 
draw a line between dual citizenship acquired voluntarily and cases where it comes about automatically or cannot be avoided. As explained above, Austria tolerates dual citizenship generally by birth and exceptionally by naturalisation when renouncing a previous nationality would be impossible or very difficult. Yet Austrian law also accepts dual citizenship if naturalisation in Austria or the retention of Austrian citizenship is in the special interest of the republic. Moreover, Austrians by descent who voluntarily acquire another nationality can apply for special permission to retain their Austrian citizenship on grounds that are denied to immigrants who want to obtain it.

The political programme of the government coalition of 2017 to 2019 formed by the Conservative and the Freedom Parties contained proposals for three further exceptions, two of which have not been carried through to the stage of legislative proposals: dual Austrian-Italian citizenship for the German- and Ladin-language groups in South Tyrol and dual citizenship as an option for Austrian expatriates affected by Brexit. The former proposal was promoted mainly by the Freedom Party and seems to have been silently dropped from the government agenda after protests by Italy although, according to media coverage, by September 2018 a draft bill already existed (Perchinig and Valchars 2019). As discussed in the concluding chapter of this book (Chapter 14 by Atz and Haller), the proposal was not even endorsed in a survey by a representative sample of the German-speaking population.

The case for dual citizenship in the context of Brexit was a stronger one, since Austrians residing in the UK would lose their rights as EU citizens if they decided to opt for British citizenship, while risking a worsened status as foreign nationals if they retained their Austrian one. The argument for tolerating dual citizenship for British citizens with long-term residence in Austria would have been even stronger since they have now involuntarily lost their EU citizenship and its right to free movement, although British expats overwhelmingly voted against Brexit. The Austrian government decided, however, to deal with this latter issue through a special "Law Accompanying Brexit" that was passed in February 2019 and which maintains residence and employment rights for British residents in Austria - although not, of course, throughout the European Union. ${ }^{31}$ The plan for special toleration of dual citizenship for Austrians in Britain was dropped after Theresa May's government provided a verbal guarantee that the rights of EU citizens already legally present in the UK would be maintained, although these are still not finally secure at the time of writing, with negotiations over future relations between Britain and the EU stalled and running out of time. ${ }^{32}$

The third proposal of a dual citizenship option for the descendants of Holocaust victims was eventually passed by parliament unanimously in September 2019, during

31 Brexit Begleitgesetz, BGBI. I 25/2019 (Law Accompanying Brexit).

32 See Chapter 6 by Peters and Vink for a similar legislative commitment in the Netherlands in case of a hard Brexit. 
the brief period of an unelected caretaker government after the collapse of the Conservative-Freedom coalition in June that year. It aimed to rectify the historic injustice whereby the Austrian citizenship transition law of 1945 excluded Holocaust survivors from restoration of their Austrian citizenship on the grounds that they had adopted another citizenship. The non-toleration of dual citizenship served as an excuse for keeping away the victims, whereas those who had lost their Austrian citizenship as illegal Nazis under the Austrofascist regime between 1934 and 1938 saw their citizenship restored. The argument for also including descendants in direct line of those persecuted by the Nazi regime was that they would have inherited their parents' Austrian citizenship had these latter not been driven into exile (Stiller forthcoming).

\section{Prospects and proposals for reform}

We opened this chapter by arguing that none of the general explanations for the resistance against dual citizenship by other states applies to Austria. Through examining the history of Austrian citizenship law and the impact of international legal norms, we have also demonstrated that Austria's rejection of dual citizenship has already been perforated by general toleration in the case of acquisition by birth and several exceptions in the case of a later change of nationality.

These findings suggest that resistance may be best explained by the evolution of the Austrian party system and government coalitions or by ideologies of national identity. The rise of the right-wing populist Freedom Party since 1986 has produced a politicisation of immigrant integration issues that has triggered frequent amendments of immigration and citizenship laws, nearly all of which were designed to address nativist sentiments through restrictive changes. Lurking behind these trends may also be a shifting discourse on national identity. In the period after World War II, Austrian nationhood had been constructed as grounded in a civic identity in order to defeat the still-strong ideology of pan-German ethnic nationalism, which regarded Austria as part of a larger German cultural nation. Popular self-identification with the Austrian nation grew after the success of economic reconstruction in the 1950s and 1960s and the strengthening of the welfare state in the 1970s. The rise of populist nationalism since the 1980s produced, however, new culturally exclusive notions of Austrian patriotism that have been mainly mobilised against immigrants. Unlike in the Nordic countries, where lobbying by expats has provided much momentum for the policy shift towards the toleration of dual citizenship, the voices of Austrians abroad have carried little weight in public debates, in spite of their strong support for the proposal (see Chapter 13 by Gundl).

If this diagnosis is correct, then changing political constellations and ideologies may unblock the stalled progress towards the general toleration of dual citizenship. We conclude this chapter with a menu of reform options that range from modest corrections of the current law to arguments for a full toleration of dual citizenship. This method of 
presentation leaves open two possible pathways towards full toleration: either through a gradual accumulation of more and more exceptions - that make retaining any remaining restrictions increasingly harder to justify - or through a direct leap towards full toleration that abolishes all current restrictions in one go. We cannot predict which of these pathways the Austrian legislator is more likely to travel but we remain optimistic that the reforms we suggest are legally compelling because they build on existing principles and are politically feasible if promoted by a sufficiently strong policy coalition.

\section{Acquisition by birth}

1. The most important overall change in Austrian citizenship law would be to modify the exclusive reliance on ius sanguinis by introducing conditional ius soli if a parent has permanent residence status. Germany, the paradigmatic case of descent-based citizenship (Brubaker 1992), took this step in 1999. Alternatively, the Austrian legislator could consider a right to citizenship for children socialised in the country according to the Swedish or Greek model. In the Swedish case, this citizenship option is not premised on birth on the territory but merely on three years of residence as a minor, after which a parent can obtain citizenship for a child by mere declaration. In any case, the requirement of renunciation of a citizenship acquired iure sanguinis at birth is a strong obstacle for parents considering whether to obtain citizenship for their children. Apart from the obvious benefit for the integration of the so-called second generation, the fact that Austria already accepts a life-long status of dual citizenship when Austrian ius sanguinis is combined with foreign ius soli provides a good reason for symmetrical toleration if a future Austrian ius soli combines with a foreign ius sanguinis. This would rule out the so-called option duty. Germany initially forced ius soli children to choose one of their two birthright citizenships on becoming adults. In 2014, this policy was abandoned for children with a sufficiently long presence in Germany (see also Chapter 3).

2. If Austria accepts our reform proposal 10 below and joins the global trend of dual citizenship toleration for emigrants who want to obtain their host country's citizenship, its unlimited ius sanguinis rules would become over-inclusive by giving persons with no social ties to the country access to its citizenship - and that of the European Union - based on distant ancestry. ${ }^{33}$ In order to avoid this indirect effect of dual-citizenship toleration, Austria should consider limiting its extraterritorial ius sanguinis to the first generation born abroad. The children of emigrants could then only pass on their Austrian citizenship to their own offspring if they have had several years of residence in Austria or have otherwise demonstrated sufficiently strong ties to the country.

${ }^{33}$ See Chapter 5 by Harpaz in this volume. 
Incoming naturalisation

3. The current default procedure for the renunciation requirement in incoming naturalisations creates temporary statelessness and - because of the re-examination of the criminal record check after renunciation - a risk of permanent statelessness. This is unacceptable under existing international law on the prevention of statelessness and possibly also in conflict with European Union norms regarding the loss of EU citizenship. Moreover, since Austria itself requires that its own nationals must already be in possession of another citizenship before they can renounce their Austrian one, it should not use a different standard for those acquiring its own citizenship.

4. Austrian citizenship law also applies different standards with regards to individual dual-citizenship permissions for Austrian citizens by descent who voluntarily acquire a foreign nationality and for applicants for Austrian citizenship. The former have to apply for permission to retain Austrian citizenship if reasons related to their private and family life deserve special consideration, while the latter are granted exemption from a renunciation requirement only if the country of origin refuses to release them or makes relinquishing exceptionally difficult. As long as Austria insists on the renunciation of a foreign citizenship as a condition for naturalisation, it should also have to consider how doing so would affect the private and family life of immigrants.

5. Following the German example, the Austrian legislator could provide for a general toleration of dual citizenship for EU citizens who acquire Austrian nationality. Germany had introduced an EU exemption from the renunciation requirement in 1999. Initially, this was limited to cases of reciprocity where the other EU state would also accept that Germans retain their citizenship when naturalising. In 2007, Germany abandoned this difficult-to-handle condition of reciprocity and exempted all EU citizens from the renunciation requirement. Such an EU exemption can be supported by arguing that the prohibition of dual citizenship is premised on distrust towards other states or assumed conflicts between rights and duties, neither of which can apply inside the European Union and its dense legal order. Second, a practical reason is that EU citizens gain very few additional rights through naturalisation in another member state and tend to attribute high value to their citizenship of origin. A renunciation requirement therefore depresses their propensity to naturalise very strongly and thus impedes their full political integration in their host country.

6. Going beyond limited exemptions, the general toleration of dual citizenship in incoming naturalisations could be supported by extending the current principle of exceptional toleration if granting Austrian citizenship is in the special interest of the republic. As a democratic state, Austria must have a general interest in the political integration of its exceptionally large population of non-citizen residents. Such an interest can be argued on two grounds: first, social scientists have demonstrated that naturalisation (if it is not offered too late) works as a catalyst for the further so- 
cial integration of immigrants (Hainmueller and Hangartner 2017; Peters, Vink and Schmeets 2018; Chapter 12 by Haindorfer and Haller in this volume). Second, the disenfranchisement of non-citizens who are comprehensively subjected to the law but not represented in legislation diminishes democratic input legitimacy (Scharpf 1999) and the quality of legislative output that fails to be responsive to the interests of a large part of the population. Since high naturalisation rates of the immigrant population are therefore in the general public interest of Austria as a democratic state, the requirement of renunciation should be abolished as a major obstacle to achieving this goal. ${ }^{34}$ Adopting such a goal would signal that Austria finally accepts that it has become an immigration country.

\section{Outgoing naturalisation}

7. Permission to retain Austrian citizenship in the case of the voluntary acquisition of a foreign nationality is currently handled by provincial authorities. The criteria for granting such permission on the grounds of an applicant's private and family life are interpreted very differently by these authorities. A minimum reform demanded by the World Association of Austrians Abroad (AÖWB) is that the federal authorities should adopt binding guidelines that prevent the arbitrary denial of the permission to retain Austrian citizenship (Em 2020). Equally important is the abolition of current discrimination between citizens by descent and by naturalisation (see Proposal 4 above).

8. The current law provides for the automatic loss of Austrian citizenship in cases of the voluntary acquisition of a foreign nationality. Like the default procedure for renunciation (see Proposal 3 above), this rule carries a significant risk of producing statelessness. Moreover, because of Austria's non-toleration of dual citizenship even for EU citizens, the deprivation of Austrian nationality also leads, in most cases, to a loss of EU citizenship. The Court of Justice of the European Union has argued in its Rottmann and Tjebbes judgments that a decision to deprive an EU citizen of his or her nationality must be proportionate and take EU law into account. These conditions require an individual examination of each case, which is impossible if the loss occurs ex lege. The deprivation of citizenship should therefore always have to be assessed individually and imply a possibility for appeal in court.

9. The reasons for permitting EU citizens to retain their member-state citizenship when becoming Austrians (see Proposal 5) apply conversely to Austrians acquiring the citizenship of another EU country. Whichever of these two reforms is adopted first should naturally trigger the corresponding other one. Privileging Austrian citizens

34 See Chapter 6 by Peters and Vink in this volume for empirical evidence that dual-citizenship toleration boosts the propensity of immigrants to naturalise. 
by allowing them to retain their nationality while denying the same opportunity to EU citizens who naturalise in Austria would breach European principles of trust and solidarity. When Germany reformed its citizenship law in 1999 it therefore introduced first a principle of reciprocity and then in 2007 the general toleration of dual citizenship in both incoming and outgoing naturalisations involving EU citizens.

10. If Austria generally abolished the rule that its citizenship is lost when a foreign nationality is acquired voluntarily it would follow a strong global trend (Vink et al. 2019). The reasons for doing so are that, like other sending countries, Austria has economic, cultural and social interests in retaining legal ties with Austrian emigrants. Moreover, Austria fails to respect the legitimate interests of its citizens abroad in enjoying a secure status, political participation rights and free movement between their country of origin and of residence if they are asked to choose between one of the two citizenships and penalises their loyalty to Austria by reducing their prospects for full opportunities and membership in their host society.

\section{References}

Bauböck, R. 2006. Interaktive Staatsbürgerschaft, in Baringhorst, S., Hunger, U. and Hollifield, J. (eds) Herausforderung Migration: Perspektiven der vergleichenden Politikwissenschaft. Festschrift für Dietrich Thränhardt. Berlin: Lit Verlag, 129-166.

Baumruck, R. 2013. Staatsbürgerinnenschaft. Die Entwicklung des österreichischen Staatsbürgerschaftsrechts für Ehefrauen und Kinder. Vienna: University of Vienna, dissertation.

Brubaker, R.W. 1992. Citizenship and Nationhood in France and Germany. Cambridge, MA: Harvard University Press.

Buschmann, G.F. von. 1833. Ueber die Österreichische Staatsbürgerschaft. Vienna: Mechitaristen.

Çağlar, A. 2004. "Citizenship light": transnational ties, multiple rules of membership, and the "pink card", in Friedmann, J. and Randeria, S. (eds) Worlds on the Move: Globalisation, Migration and Cultural Security. London: I.B. Tauris, 273-291.

De Groot, G.-R. 2019. Beschouwingen over het HvJ EU-arrest Tjebbes, Asiel-en Migrantenrecht, 444-451.

De Groot, D. 2020. CJEU asked to rule on acquisition of nationality in light of EU citizenship: the fundamental status on the horizon? GLOBALCIT Blog, https://globalcit.eu/ cjeu-asked-to-rule-on-acquisition-of-nationality-in-light-of-eu-citizenship-the-fundamental-status-on-the-horizon-c-118-20-jy-v-wiener-landesregierung/ (accessed 01 December 2020).

Ecker, J. 2017. § 14, in Ecker, J., Kind, M., Kvasina, I. and Peyrl, J. (eds) StbG 1985. Staatsbürgerschaftsgesetz 1985. Kommentar. Vienna: Verlag Österreich, 361-371.

Em, J. 2020. Kommentar, Rotweißrot 1/2020, 9. Available at: https://www.weltbund.at/ rot-weiss-rot/rotweissrot-ausgabe-1-2020/ (accessed 02 December 2020). 
Hainmueller, J. and Hangartner, D. 2017. Catalyst or crown: does naturalization promote the long-term social integration of immigrants? American Political Science Review, 111(2): 256-276.

Kadirbeyoğlu, Z. 2012. Country Report: Turkey. Florence: European University Institute, Robert Schuman Centre for Advanced Studies, EUDO Citizenship Observatory, RSCAS/EUDO-CIT-CR 2012/10. Available at: https://cadmus.eui.eu/bitstream/handle/1814/19640/RSCAS_EUDO_CIT_2012_10.pdf (accessed 02 December 2020).

Mediendienst Integration 2019. Staatsangehörigkeit und Einbürgerung. Available at: https://mediendienst-integration.de/migration/staatsbuergerschaft.html (accessed 02 December 2020).

Neuwirth, K. 2015. Umsetzung von Art. 9 in Österreich, in Schläppi, E., Ulrich, S. and Wyttenbach, J. (eds) CEDAW. Kommentar zum UNO-Übereinkommen über die Beseitigung jeder Form der Diskriminierung der Frau. Vienna: Manz, 681-696.

Obwexer, W. 2018. Rechtliche Rahmenbedingungen für den Erwerb der österreichischen Staatsbürgerschaft durch "Südtiroler", Journal für Rechtspolitik, 26(1): 25-48.

Peters, F., Vink, M. and Schmeets, H. 2018. Anticipating the citizenship premium: before and after effects of immigrant naturalisation on employment, Journal of Ethnic and Migration Studies, 44(7): 1051-1080. DOI: 10.1080/1369183X.2017.1367650.

Perchinig, B. and Valchars, G. 2019. Einwanderungs- und Integrationspolitik, in Tálos, E. (ed.) Die Schwarz-Blaue Wende in Österreich. Eine Bilanz. Vienna: Lit Verlag, 413-439.

Peyrl, J. 2017a. § 27, in Ecker, J., Kind, M., Kvasina, I. and Peyrl, J. (eds) StbG 1985. Staatsbürgerschaftsgesetz 1985. Kommentar. Vienna: Verlag Österreich, 504-510.

Peyrl, J. 2017b. § 28, in Ecker, J., Kind, M., Kvasina, I. and Peyrl, J. (eds) StbG 1985. Staatsbürgerschaftsgesetz 1985. Kommentar. Vienna: Verlag Österreich, 510-520.

Rieder, C. 2016. Zur Bewilligung von Doppelstaatsbürgerschaften im österreichischen Staatsbürgerschaftsgesetz 1985 - eine kritische Analyse, juridikum, 3/2016: 339-349.

Scharpf, F. 1999. Governing in Europe: Effective and Democratic? New York: Oxford University Press.

Stern, J. and Valchars, G. 2013. Country Report: Austria. Florence: European University Institute, Robert Schuman Centre for Advanced Studies. EUDO Citizenship Observatory, RSCAS/EUDO-CIT-CR 2013/28. Available at: https://cadmus.eui.eu/bitstream/ handle/1814/60232/RSCAS_EUDO_CIT_2013_28.pdf (accessed 02 December 2020).

Stiller, M. Forthcoming. Verfolgung, Flucht, Verlust der österreichischen Staatsbürgerschaft. Überlegungen zu Österreichs Maßnahmen im Zusammenhang mit austrofaschistischem und nationalsozialistischem Staatsbürgerschaftsentzug.

Thienel, R. 1989/1990. Österreichische Staatsbürgerschaft. Band I und II. Vienna: Österreichische Staatsdruckerei.

Vink, M., Schakel, A.H., Reichel, D., Chun Luk, N. and de Groot, G.-R. 2019. The international diffusion of expatriate dual citizenship, Migration Studies, 7(3): 362-383. 



\title{
Chapter 11
}

\section{The Potential for Naturalisation in Austria: A Statistical Approximation}

\author{
Stephan Marik-Lebeck, Statistics Austria
}

\begin{abstract}
Naturalisation in Austria, as in most countries, is bound by certain conditions. Among others these entail an uninterrupted stay in the country for at least ten years (in special circumstances, only six years are required). Information from the Central Residence Register processed in the population statistics of Statistics Austria allows for an estimation of how many people currently living in Austria would fulfil this specific condition and therefore potentially qualify for naturalisation. The chapter presents the results of these estimations, disaggregated by citizenship, age and region of residence. EU/EFTA citizens in Austria have little propensity for naturalisation. Among non-EU/EFTA citizens, the propensity for naturalisation was higher and increasing over time. The naturalisation of all non-EU/EFTA citizens with ten years or more of residence in Austria would reduce the share of foreign citizens there from 16.7 to 13 per cent. This would roughly offset the increase in the foreign population in Austria in the last five years. The naturalisation of eligible EU/EFTA citizens would further reduce the foreigners' share in the population to 10 per cent. If persons with a residence period of between six and ten years were also all naturalised, the percentage of foreigners would drop even further to 7.5 per cent, less than half the actual share recorded on 01 January 2020. At a regional level, Vienna has the highest potential for naturalisation, followed by Vorarlberg and Salzburg, if only non-EU/EFTA citizens residing there for ten years or more are counted.
\end{abstract}

\section{Introduction}

In this section, I first provide an overview of the conditions for naturalisation in Austria and compare them with other countries; I then describe the actual length of stay of the non-citizen population in Austria. As in most countries, naturalisation in Austria depends on certain conditions, with the Austrian Citizenship Act stipulating several dimensions of pre-requisites:

- a minimum length of continuous registration with a main residence in Austria;

- a clean criminal record of the person applying for naturalisation;

- a minimum proficiency in German (currently at level B2);

- a pass in a civic knowledge test; 
- an affirmation of Austrian civic values;

- a sufficient income and no claiming of social benefits; and

- the renunciation of any other citizenship.

Of these, only the minimum length of stay in Austria is statistically quantifiable and thus may be used for an estimation of how many people currently living in Austria would potentially qualify for naturalisation. The minimum length of uninterrupted stay in Austria required for naturalisation is basically set at ten years but may be shortened to six for those spouses of Austrian nationals with a duration of marriage of more than five years. It may equally be reduced to six years for particularly well-integrated immigrants (who have committed to at least three years of volunteering in non-profit organisations or showing other relevant commitment) or where there are other considerable reasons. The citizenship law regulates the extent to which residence in Austria must be uninterrupted and that, of the ten years required for ordinary naturalisation, the applicant must have held a permanent residence (settlement) permit for at least five. These further conditions are not captured in the population statistics but they do imply that many immigrants with ten years' residence are still not eligible for naturalisation.

Thus, when looking at the length of stay in Austria, it is particularly interesting to know about the number of people with foreign citizenship who have been residing in Austria without interruption for ten years or more. In addition, it seems feasible to differentiate between EU or EFTA and third-country nationality, as EU/EFTA citizens largely have the same rights as Austrian nationals and thus may be less inclined to aspire to Austrian citizenship. ${ }^{1}$ A further categorisation of people residing for less than ten years into a group staying less than six years and those staying between six and ten years also seems feasible in order to detect the number of those who potentially qualify for early access to Austrian citizenship after six years of residence. Data for this analysis have been produced by looking at the latest start date of a record of uninterrupted registration of a main residence in Austria. ${ }^{2}$ Consequently, a time span up to different reference dates

1 Legally the right for non-discrimination applies to European Union (EU) and European Economic Area (EEA, comprised of Iceland, Norway and Liechtenstein) citizens. Swiss citizens have de facto been accorded the same rights in mutual agreements between Switzerland and the EU. As the European Free Trade Association (EFTA) is comprised of all EEA members plus Switzerland, "EU/ EFTA" is used as a collective term in this analysis for foreigners enjoying largely the same rights as Austrian nationals.

2 Gaps in registration are allowed for up to 90 days, as this is the length of validity of tourist visas and, at the same time, the minimum period of absence required before re-entering the country with a tourist visa after expiry of a previous visa. We can assume that people with an expired residence permit during their stay in Austria will also be de-registered by the competent authorities - unpublished research by the author for the period 2002 to 2007 has shown that about one third of all de-registrations in Austria are made by the authorities. For third-country nationals these usually reflect expired residence permits but are only performed if the person 
has been calculated and classified into three categories, as specified under Austrian naturalisation law: continuous residence of less than six years, of six to ten years and of ten years or more. As register-based data from the Austrian Population Statistics database (POPREG) go back to the beginning of 2002, a study on the length of residence is feasible for 01 January 2012 at the earliest.

\section{Comparison with other countries}

Conditions for naturalisation differ widely among EU member states (Bauböck, Honohan, Huddleston, Hutcheson, Shaw and Vink 2013). There are significant differences in the use of ius soli and ius sanguinis for migrant-origin populations. In addition, all member states specify a certain minimum length of residence which is required for naturalisation. This ranges from four to ten years. Austria, with a general threshold of ten years (and six years for accelerated access to citizenship) is at the upper limit of this range. Moreover, there are different levels of additional requirements such as language skills, civic-knowledge tests and cultural assimilation requirements. Although this is less-common practice among EU member states, Austria has also set quite demanding requirements for naturalisation as far as employment or economic resources are concerned. These may also further reduce the propensity for naturalisation of foreign citizens otherwise fulfilling the prerequisites.

Rössl and Valchars (2019) indicate that, in 2019, the minimum requirement for naturalisation in Austria for a single person was $€ 933$ of monthly net income after payment of rent, allowances and loan rates (and no use of social benefits). ${ }^{3}$ In addition, there were several administrative fees. Naturalisation in 2019 cost $€ 1,115.30$ for a single person, plus the respective state tax and the considerable costs for the translation and certification of documents (Wagner 2019). Overall, these requirements constitute a high social barrier to naturalisation. A considerable share of the Austrian population - both citizens and non-citizens - would be unable to overcome this barrier, despite their income from employment. Income statistics for 2018 (Statistics Austria 2019) show that, in Austria, irrespective of citizenship, more than 25 per cent of employees ( $>30$ per cent of females and $>20$ of males) earn less than this requirement, as many of them are in unstable employment. For blue-collar workers, among whom foreign nationals are over-represented, more than 50 per cent of females and over 25 per cent of males have less income than is required for the granting of Austrian citizenship.

concerned is not present at the last known address. Data may be less accurate for EU/EFTA citizens, as information on persons leaving the country is usually not immediately available to the authorities. However, annual population counts for tax-sharing needs link several administrative registers and identify nominal members (having left the country) in this way.

3 Proof of the necessary income must be provided for an average of 36 months out of the last six years prior to the application for naturalisation - and, in any case, for the last six months immediately preceding the application (Rössl and Valchars 2019, 305). Furthermore, income requirements are adjusted for inflation every year. 
Before turning to the potential for naturalisation, we should first examine the actual number of naturalisations occurring in Austria compared to other European countries. The European Statistical Office, Eurostat, collects raw naturalisation rates for each member state - that is, the number of naturalisations in relation to the foreign population registered in that member state. For the comparison, it seemed feasible to look at naturalisation rates during those years for which Austrian population data on length of stay are also available. As the Austrian population register started in 2002, the number of people with a length of stay of more than ten years in Austria could first be established for the reference year 2012. Taking the period from 2012 to 2020 as a reference, it ought to be feasible to separate a pre- and post- 2015 period, as the composition of immigration into the EU in 2015 and 2016 differed markedly from that in other years.

Compared to similar European countries of immigration, Austria has low naturalisation rates - the raw naturalisation rate in EU/EFTA countries during the 2012-2014 period was 2.64 naturalisations per 100 resident foreigners. Austria had 0.73 and was thus comparable to countries like Czechia (0.70) and Denmark (0.89). Most European countries with larger immigrant populations had higher rates - e.g. Germany (1.69), France (2.44), Italy (2.18) and the Netherlands (4.17). Switzerland had 1.79 and Norway 3.12 naturalisations per 100 resident foreigners. However, the highest rates were observed in Sweden (7.24).

Yet raw naturalisation rates do not clearly reflect the differences in eligibility of the resident foreign population in different countries. ${ }^{4}$ For a first approximation of potential differences, it may be useful to disaggregate data by EU and non-EU citizens. The rates in this case vary more markedly, being somewhat low in general for EU citizens and significantly higher for non-EU citizens. This reflects a general pattern whereby naturalisation is less relevant for EU citizens, as they enjoy largely the same rights as nationals. Under EU law, long-term residents in Austria with EU/EFTA citizenship face few legal restrictions in their daily lives in Austria - they enjoy, for example, greater security of residence, free access to employment and the right to non-discrimination on the grounds of nationality - and thus have less incentive to naturalise than other foreign citizens.

The average naturalisation rate for EU citizens in the period 2012-2014 was 1.14 for all EU/EFTA countries. There was a significant exception in Hungary (11.89), resulting from the granting of dual citizenship to ethnic Hungarians residing in Romania, Slovakia and Serbia (Vojvodina). Austria (0.21) was among the lowest-ranking groups, together with Spain (0.14) and Slovakia (0.12) - although apparently for different reasons. Spain had a massive economic crisis during this period, while Slovakia has very few residents from other EU member states. For Austria the cause seems to be different: while most EU member states tolerate dual citizenship generally or specifically for EU/EFTA citizens,

4 For a discussion of the use of raw naturalisation rates in Austria, see Reichel (2012). Wanner and Galleano (2020), in their study of Switzerland, plead for the use of standardised rates in order to avoid the influence of different compositions of the resident foreign population. 
Austria requires them to renounce their previous nationality, which helps to explain the particularly low naturalisation rates among EU/EFTA citizens in Austria. ${ }^{5}$

On average, 4.05 out of 100 resident non-EU citizens were naturalised in 2012-2014 in EU/EFTA countries. High rates could be observed in Sweden (9.96), the Netherlands (7.91) and Norway (7.23). To a lesser extent, Spain (5.95), Poland (5.25) and Belgium (5.57) also had high naturalisation rates. Germany (2.28), Italy (2.83) and Switzerland (2.68) were all below average, although still higher than Austria (1.14). Czechia (0.90), Slovakia (1.09) and Slovenia (1.45) had similar rates to Austria.

Table 11.1. Residents who acquired citizenship as a share of resident non-citizens by former citizenship 2012-2018 in selected EU/EFTA countries (in \%)

\begin{tabular}{lccccccc}
\hline & \multicolumn{3}{c}{$\mathbf{2 0 1 2 - 2 0 1 4}$} & \multicolumn{3}{c}{$\mathbf{2 0 1 5 - 2 0 1 8}$} \\
\cline { 2 - 7 } & $\begin{array}{c}\text { All foreign } \\
\text { citizens }\end{array}$ & $\begin{array}{c}\text { EU } \\
\text { citizens }\end{array}$ & $\begin{array}{c}\text { Non-EU } \\
\text { citizens }\end{array}$ & $\begin{array}{c}\text { All foreign } \\
\text { citizens }\end{array}$ & $\begin{array}{c}\text { EU } \\
\text { citizens }\end{array}$ & $\begin{array}{c}\text { Non-EU } \\
\text { citizens }\end{array}$ \\
\hline EU, EFTA & $\mathbf{2 . 6 4}$ & $\mathbf{1 . 1 4}$ & $\mathbf{4 . 0 5}$ & $\mathbf{2 . 4 0}$ & $\mathbf{0 . 9 5}$ & $\mathbf{3 . 8 4}$ \\
Belgium & 2.53 & 0.91 & 5.57 & 2.49 & 1.03 & 5.24 \\
Czechia & 0.70 & 0.38 & 0.90 & 0.67 & 0.33 & 0.89 \\
Denmark & 0.89 & 0.18 & 1.34 & 2.02 & 0.60 & 3.02 \\
Germany & 1.69 & 0.83 & 2.28 & 1.31 & 0.86 & 1.66 \\
Spain & 3.55 & 0.14 & 5.95 & 2.37 & 0.14 & 4.08 \\
France & 2.44 & 0.64 & 3.30 & 2.53 & 0.64 & 3.42 \\
Italy & 2.18 & 0.55 & 2.83 & 3.16 & 0.92 & 4.13 \\
Hungary & 8.52 & 11.89 & 4.07 & 2.39 & 3.32 & 1.36 \\
Netherlands & 4.17 & 0.40 & 7.91 & 3.21 & 0.59 & 6.29 \\
Austria & $\mathbf{0 . 7 3}$ & $\mathbf{0 . 2 1}$ & $\mathbf{1 . 1 4}$ & $\mathbf{0 . 6 9}$ & $\mathbf{0 . 2 3}$ & $\mathbf{1 . 1 3}$ \\
Poland & 4.22 & 1.59 & 5.25 & 2.57 & 0.77 & 3.03 \\
Slovenia & 1.48 & 2.29 & 1.45 & 1.36 & 0.39 & 1.55 \\
Slovakia & 0.35 & 0.12 & 1.09 & 0.79 & 0.39 & 2.08 \\
Sweden & 7.24 & 3.24 & 9.96 & 7.51 & 3.89 & 9.49 \\
Norway & 3.12 & 0.53 & 7.23 & 2.67 & 0.40 & 6.55 \\
Switzerland & 1.79 & 1.28 & 2.68 & 2.07 & 1.72 & 2.75 \\
\hline
\end{tabular}

Source: Eurostat [migr_acqs].

Overall, this picture did not change substantially during the $2015-2018$ period, ${ }^{6}$ although naturalisation rates tended to be a little bit lower. This was mainly the result of an increase in the overall foreign population in most EU member states in 2015 and 2016, while the

\footnotetext{
5 See the contribution of Peters and Vink - in Chapter 6 of this book - on the impact of renunciation requirements in the Netherlands.

6 The latest year with data available at a European level was 2018 at the time of writing (May 2020).
} 
absolute number of naturalisations did not change much. As in the previous period, naturalisations among EU citizens were fairly low in most countries. The EU/EFTA average was 0.95 per $100 \mathrm{EU}$ residents, with Sweden (3.89) and Hungary (3.32) again being notable exceptions, although the latter did not come anywhere near the exceptional figures of 2012-2014. At 0.23, Austria's naturalisation rate was the second-lowest.

Naturalisation rates varied more among EU/EFTA countries for non-EU citizens, ranging from 9.49 in Sweden to just 0.89 in Czechia. Austria was also on the lower edge for this group, registering 1.13 naturalisations per 100 resident non-EU citizens in 2015-2018.

Overall, we can see that Austria has very low naturalisation rates given the size and duration of settlement of its foreign population (see Chapter 2 by Haller in this volume). Countries with a similar population structure to Germany and, to a lesser extent, Switzerland, have higher naturalisation rates, although these are still low in a comparative perspective for Western Europe. Austria seems to be more in line with Central European countries like Czechia, Slovakia and Slovenia - which, however, have much smaller populations of foreign citizens stemming from more-recent immigration. As shown by Bauböck et al. (2013) and Stadlmair (2017), the options for retaining dual citizenship are less generous in Austria than in other Western European EU member states. While these tolerate dual citizenship, whether generally or specifically for EU/EFTA citizens, Austria also requires EU/EFTA citizens to renounce their previous nationality, which helps to explain the particularly low naturalisation rates among this group in Austria. Labussière and Vink (2020) show, for the Netherlands, that more-restrictive institutional circumstances, such as mandatory civic integration and restrictions on dual citizenship, lead to later and less-frequent naturalisations among migrants, despite their similar eligibility.

In addition, the timing of naturalisation may play a decisive role. Several studies (Labussière and Vink 2020; Peters, Vink and Schmeets 2015; Reichel 2011) show that some migrants may wish to access citizenship as quickly as possible. Others may not be interested initially but may develop an interest later. Timing is mostly related to a migrant's origins, age at immigration, reason for migration or mode of entering the host country. Younger immigrants and those with a native partner naturalise more often. Apart from naturalisation policy, the differences in naturalisation rates observed may also stem, to some extent, from differences in the eligible population. Let us now turn, in a first step, to the establishment of the total number of the foreign population in Austria eligible for naturalisation on the basis of length of residence.

\section{The actual length of stay of the resident population in Austria}

Of the $8,902,600$ people registered with a main residence in Austria for more than 90 days on 01 January 2020, more than four-fifths (81.1 per cent or 7.2 million people) had been living there for more than ten years. A little over half a million ( 6 per cent) had a registered length of residence of between six and ten years, while around 1.15 million 
(12.9 per cent) had been in the country for less than six years. Of course, for Austrian nationals, these figures mostly reflect births occurring during the previous ten years ${ }^{7}$ and, to a certain (but fairly small) extent, naturalisations ${ }^{8}$ or Austrian citizens returning to Austria from abroad and taking up residence there. ${ }^{9}$

In contrast, for foreign citizens residing in Austria, the share of births is much less important. During the period 2014 to 2019 , some 102,876 births of foreign citizens occurred in Austria. In comparison, the overall number of foreigners having registered in Austria for the first time during this period is nearly five times greater at 917,680 . Nonetheless, there were only 667,618 foreign citizens on 01 January 2020 with a period of stay of less than six years. The difference with the number of immigrants and births is due to the emigration and death of members of this group.

\section{Table 11.2. Population in Austria on $1 / 1 / 2020$ by citizenship and length of registered stay}

\begin{tabular}{lcccccccc}
\hline \multirow{2}{*}{$\begin{array}{l}\text { Population on } \\
\mathbf{1 / 1 / 2 0 2 0}\end{array}$} & & \multicolumn{6}{c}{ Registered length of stay on reference date } \\
\cline { 3 - 8 } & Total & No. & \%ears & 6-10 years & \multicolumn{3}{c}{$\mathbf{1 0 + \text { years }}$} \\
\cline { 3 - 8 } & $8,902,600$ & $1,152,391$ & 12.9 & 533,812 & 6.0 & $7,216,397$ & 81.1 \\
\hline All citizens & $1,487,020$ & 667,618 & 44.9 & 224,197 & 15.1 & 595,205 & 40.0 \\
Foreign citizens & 16.7 & 7.5 & & 2.5 & & 6.7 & \\
\% of total & $\mathbf{7 7 8 , 8 4 4}$ & $\mathbf{3 8 0 , 1 6 1}$ & $\mathbf{4 8 . 8}$ & $\mathbf{1 3 3 , 9 3 3}$ & $\mathbf{1 7 . 2}$ & $\mathbf{2 6 4 , 7 5 0}$ & $\mathbf{3 4 . 0}$ \\
EU/EFTA & 8.7 & 4.3 & & 1.5 & & 3.0 & \\
\% of total & $\mathbf{7 0 8 , 1 7 6}$ & $\mathbf{2 8 7 , 4 5 7}$ & $\mathbf{4 0 . 6}$ & $\mathbf{9 0 , 2 6 4}$ & $\mathbf{1 2 . 7}$ & $\mathbf{3 3 0 , 4 5 5}$ & $\mathbf{4 6 . 7}$ \\
Non-EU/EFTA & 8.0 & 3.2 & & 1.0 & & 3.7 & \\
\% of total & & & & & & &
\end{tabular}

Source: Statistics Austria, Population Statistics - Preliminary results for 1/1/2020.

Foreigners having lived for ten years or more in Austria on 01 January 2020 - and thus potentially eligible for naturalisation - made up 40 per cent of the overall foreign population. In absolute numbers, this group covered almost 600,000 people and represented 6.7 per cent of the total population. Thus, if all these people were to be naturalised, the share of foreign citizens in the total population would drop from 16.7 to just 10 per cent. In a

7 There were 408,569 births of Austrian citizens in Austria in the period 2014-2019 (six years prior to 01 January 2020). A further 264,227 births occurred during 2010-2013 (between more than six and ten years prior to 01 January 2020).

8 There were 53,911 naturalisations of people residing in Austria during the period 2014-2019 and a further 27,469 during 2010-2013.

9 Between 2012 and 2019, some 123,980 Austrian citizens immigrated to Austria. However, not all of these may have remained permanently in the country, as there were also 167,520 emigrations of Austrian citizens during the same period. 
first step, we may thus conclude that the potential for naturalisation in Austria amounts at least to some 600,000 people. However, we have to take into account several factors in order to approximate the number more closely.

Around a further 225,000 foreign citizens had been in Austria for between six and ten years by 01 January 2020, comprising a share of 15 per cent of the foreign and 2.5 per cent of the overall population. Members of this group would potentially qualify for early access to Austrian citizenship. If all members of this group made use of this opportunity, the share of remaining foreigners in the total population would come down further to 7.5 per cent.

These 7.5 per cent of the population represent the 670,000 foreign citizens who had lived in Austria for less than six years by 01 January 2020. They account for 45 per cent of the foreign population. Their share clearly reflects the large migration inflows to Austria during recent years. EU and EFTA citizens boasted a higher share of people with less than six years of residence in Austria (48.8 per cent) than third-country nationals (40.6). In other words, almost half of the EU/EFTA citizens living in Austria on 01 January 2020 moved there within the previous six years while, among third-country nationals, the share was only two-fifths. This can be traced back, on the one hand, to greater mobility among EU/EFTA citizens - who also face fewer restrictions for residence in Austria. On the other hand, EU/EFTA citizens in Austria are mostly German citizens whose immigration is driven, to a great extent, by migrants returning once their education is finished and thus staying for shorter periods in Austria.

Under current law, these people would not be eligible for naturalisation except in cases of its extension to the underage family members of naturalised persons. In order to determine the potential for naturalisation within this group, we would need to take a closer look at the age structure of the population, as set out below.

After having roughly determined a starting point for the potential for naturalisation in Austria, we need to fine-tune this number. As a first additional argument, we need to take into account that EU/EFTA citizens have little incentive to naturalise, as explained in Section 2 above. Of the almost 600,000 foreigners (6.7 per cent of the total population) with a residence of ten years or more in Austria, about 330,000 (55 per cent or 3.7 per cent of the total population) were third-country nationals and only 265,000 (45 per cent or 3 per cent of the total population) held the citizenship of an EU or EFTA member state. This mainly reflects the large number of immigrants from the Western Balkans and Turkey who arrived in Austria between the mid-1960s and the early 1990s and who have still not acquired Austrian citizenship, for whatever reason.

We may thus assume that naturalisation is more likely for the 330,000 people with third-country nationalities residing in Austria for more than ten years. This group represents 22.2 per cent of all foreigners living in Austria and 3.7 per cent of the total population. If all members of this group were naturalised, the share of foreigners in the Austrian population on 01 January 2020 would fall from 16.7 to 13 per cent. If all eligible EU/EFTA 
citizens were also naturalised, the share of the foreign population in Austria would drop further to just 10 per cent.

\section{The potential for naturalisation among different groups of non-citizens living in Austria}

Let us now investigate the main issue of this chapter - the potential for naturalisation of non-citizens living in Austria. We first take a closer look at particular nationalities whose potential for naturalisation differs to some extent. Three groups are considered here: EU/EFTA nationals, European third-country nationals and non-European third-country nationals. Subsequently, we also describe their age structure and any differences between the Austrian provinces regarding the share of non-citizens.

\subsection{Naturalisation potential among the EU and EFTA nationalities living in Austria}

For the sake of completeness, we start with EU/EFTA citizens and determine the share of persons in this group residing in Austria for ten years or more. At roughly 265,000 members, they represent 17.8 per cent of all foreigners and 3 per cent of the total population. Within this group there are about 124,000 nationals of EU member states prior to 2004 and other EFTA countries (8.4 per cent of all foreigners and 1.4 per cent of the total population). The largest cohort within this subgroup is formed by Germans, with almost 88,000 persons living for ten years or more in Austria. Also notable are Italians, with nearly 10,000 persons potentially eligible for naturalisation.

A larger subgroup is formed by citizens of the $13 \mathrm{EU}$ member states that joined after 2004. Overall, there are about 140,000 people with these nationalities who have lived in Austria for more than ten years, representing 9.4 per cent of all foreigners and 1.6 per cent of the total population. The largest nationalities among this sub-group are Croatians, with almost 50,000 people, followed by Poles with 27,000 and Romanians with 24,000 respectively. Compared to the overall number of people with the same citizenship residing in Austria, Hungary (14 per cent), Bulgaria (17.2 per cent) and Romania (19.3 per cent), in particular, have low shares of long-term residents. This clearly reflects the transitory restrictions for access to employment which applied to citizens of these EU member states. Austria was among those countries that used the maximum seven-year period for these restrictions, which were only lifted in 2012 for Hungary and in 2014 for Romania and Bulgaria and which held back larger migration inflows to Austria before these dates. In contrast, the very high share of Croatian nationals residing for more than ten years in Austria (almost 60 per cent) stems from immigration during the guestworker period or the Balkan crisis in the 1990s. As shown later, this share is similar or even higher for Serbian (65 per cent) and Bosnian (68.1 per cent) citizens, clearly indicating a common migration pattern for these three countries that has only been altered by Croatia's accession to the EU in 2013 and the resulting facilitation of migration to Austria. 
Table 11.3. Population in Austria on $1 / 1 / 2020$ by EU/EFTA citizenship and length of registered stay

\begin{tabular}{|c|c|c|c|c|c|c|c|}
\hline \multirow{3}{*}{$\begin{array}{l}\text { Population on } \\
1 / 1 / 2020\end{array}$} & & \multicolumn{6}{|c|}{ Registered length of stay on reference date } \\
\hline & & \multicolumn{2}{|c|}{$6-10$ years } & \multicolumn{4}{|c|}{$10+$ years } \\
\hline & Total & No. & $\begin{array}{c}\% \\
\text { same } \\
\text { ctz }\end{array}$ & No. & $\begin{array}{c}\% \\
\text { same } \\
\text { ctz }\end{array}$ & $\begin{array}{c}\% \text { all } \\
\text { for- } \\
\text { eigners }\end{array}$ & $\begin{array}{c}\% \text { total } \\
\text { pop. }\end{array}$ \\
\hline EU/EFTA & 778,844 & 133,933 & 17.2 & 264,750 & 34.0 & 17.8 & 3.0 \\
\hline \multicolumn{8}{|c|}{$\begin{array}{l}\text { EU member states } \\
\text { prior to } 2004 \text { (14), }\end{array}$} \\
\hline EFTA & 303,461 & 51,568 & 17.0 & 124,422 & 41.0 & 8.4 & 1.4 \\
\hline Germany & 200,059 & 35,329 & 17.7 & 87,974 & 44.0 & 5.9 & 1.0 \\
\hline Italy & 32,506 & 5,195 & 16.0 & 9,654 & 29.7 & 0.6 & 0.1 \\
\hline \multicolumn{8}{|c|}{ EU member states } \\
\hline after 2004 (13) & 475,383 & 82,365 & 17.3 & 140,328 & 29.5 & 9.4 & 1.6 \\
\hline Romania & 123,461 & 21,311 & 17.3 & 23,810 & 19.3 & 1.6 & 0.3 \\
\hline Hungary & 87,604 & 18,982 & 21.7 & 12,261 & 14.0 & 0.8 & 0.1 \\
\hline Croatia & 83,605 & 6,670 & 8.0 & 49,634 & 59.4 & 3.3 & 0.6 \\
\hline Poland & 64,454 & 13,042 & 20.2 & 27,063 & 42.0 & 1.8 & 0.3 \\
\hline Slovakia & 43,643 & 9,612 & 22.0 & 10,703 & 24.5 & 0.7 & 0.1 \\
\hline Bulgaria & 32,566 & 5,522 & 17.0 & 5,604 & 17.2 & 0.4 & 0.1 \\
\hline Slovenia & 21,461 & 3,727 & 17.4 & 4,992 & 23.3 & 0.3 & 0.1 \\
\hline
\end{tabular}

Source: Statistics Austria, Population Statistics - Preliminary results for 1/1/2020.

\subsection{Naturalisation potential among European third-country nationals living in Austria}

We now turn our attention to people with third-country nationality who have resided for more than ten years in Austria. Of the 330,000 members of this group, 193,000 (58.3 per cent) are from European non-EU/EFTA countries. The largest groups are formed by nearly 80,000 Serbian citizens and 66,000 Bosnians. Other notable nationalities among this group include those from the Russian Federation, with 15,000 citizens residing for more than ten years in Austria, as well as 14,000 North Macedonian and 13,000 Kosovan citizens.

The single largest nationality among third-country nationals residing for ten years or more in Austria is Turkish. About 83,000 persons belong to this group, representing 5.6 per cent of all foreigners and 0.9 per cent of the total population. Turkish citizens make up an especially high share of residents living for over ten years in Austria (70.8 per cent), reflecting that immigration from Turkey to Austria has been quite low (at about 3,000 people per year) over the last 15 years. Taking together European third countries and Turkey, about 275,000 people have been resident in Austria for ten years or more and would potentially be eligible for naturalisation. This represents 83.5 per cent of all 
third-country nationals in this group as well as 18.6 per cent of all foreigners - irrespective of the length of stay - and 3.1 per cent of the overall population.

\section{Table 11.4. Population in Austria on $1 / 1 / 2020$ by non-EU/EFTA citizenship and length of registered stay}

\begin{tabular}{|c|c|c|c|c|c|c|c|}
\hline \multirow{3}{*}{$\begin{array}{l}\text { Population on } \\
1 / 1 / 2020\end{array}$} & \multirow[b]{3}{*}{ Total } & \multicolumn{6}{|c|}{ Registered length of stay on reference date } \\
\hline & & \multicolumn{2}{|c|}{$6-10$ years } & \multicolumn{4}{|c|}{$10+$ years } \\
\hline & & No. & $\begin{array}{c}\% \\
\text { same } \\
\text { ctz }\end{array}$ & No. & $\begin{array}{c}\% \\
\text { same } \\
\text { ctz }\end{array}$ & $\begin{array}{c}\% \text { all } \\
\text { for- } \\
\text { eigners }\end{array}$ & $\begin{array}{c}\% \text { total } \\
\text { popn }\end{array}$ \\
\hline Non-EU/EFTA & 708,176 & 90,264 & 12.7 & 330,455 & 46.7 & 22.2 & 3.7 \\
\hline \multicolumn{8}{|l|}{$\begin{array}{l}\text { European } \\
\text { non-EU/EFTA }\end{array}$} \\
\hline (incl. Rusian Fed.) & 321,182 & 39,224 & 12.2 & 192,610 & 60.0 & 13.0 & 2.2 \\
\hline$\%$ non-EU/EFTA & 45.4 & 43.5 & & 58.3 & & & \\
\hline Serbia & 122,364 & 12,805 & 10.5 & 79,506 & 65.0 & 5.3 & 0.9 \\
\hline Bosnia & 96,635 & 9,059 & 9.4 & 65,824 & 68.1 & 4.4 & 0.7 \\
\hline Russian Fed. & 32,868 & 6,479 & 19.7 & 15,150 & 46.1 & 1.0 & 0.2 \\
\hline Kosovo & 26,047 & 4,611 & 17.7 & 12,994 & 49.9 & 0.9 & 0.1 \\
\hline North Macedonia & 24,100 & 3,102 & 12.9 & 13,576 & 56.3 & 0.9 & 0.2 \\
\hline Turkey & 117,640 & 13,095 & 11.1 & 83,283 & 70.8 & 5.6 & 0.9 \\
\hline$\%$ non-EU/EFTA & 16.6 & 14.5 & & 25.2 & & & \\
\hline \multicolumn{8}{|l|}{ European non-EU/ } \\
\hline EFTA + Turkey & 438,822 & 52,319 & 11.9 & 275,893 & 62.9 & 18.6 & 3.1 \\
\hline$\%$ non-EU/EFTA & 62.0 & 58.0 & & 83.5 & & & \\
\hline
\end{tabular}

Source: Statistics Austria, Population Statistics - Preliminary results for 1/1/2020.

\subsection{Naturalisation potential among non-European citizens living in Austria}

On 01 January 2020, about 270,000 citizens of non-European countries were living in Austria, about 38 per cent of all non-EU/EFTA citizens. Of these, only 20.3 per cent $(55,000$ people) had been resident in Austria for ten years or more. A further 14.1 per cent $(38,000$ people) had lived there for between six and ten years. Correspondingly, the vast majority of almost two-thirds (177,000 people or 65.7 per cent) of non-European citizens living in Austria had entered the country during the previous five years.

This distribution can be mainly attributed to citizens of just two countries: with about 51,000 from Syria and 44,000 from Afghanistan, these two countries each had more nationals living in Austria on 01 January 2020 than those originating from the African continent as a whole (about 36,000 citizens of African states) or North, Central and South America together (23,000 citizens). Yet, only very few of them had been living in Austria for ten years or more: among Syrians the share was 1.3 per cent (682 people); among Afghans, it was a little higher at 7.9 per cent (3,500 people), indicating 
that immigration from Afghanistan to Austria had started to increase slightly earlier. The share of people staying between six and ten years was quite a bit higher for both nationalities as well: some 2,400 Syrian citizens (4.6 per cent) and almost 8,000 Afghan citizens (18.3 per cent) fulfilled this condition. Overall, of 192,000 Asian citizens living in Austria on 01 January 2020, only one sixth (32,000 people or 16.8 per cent) had been there for ten years or more.

\section{Table 11.5. Population in Austria on $1 / 1 / 2020$ by non-European citizenship and length of registered stay}

\begin{tabular}{|c|c|c|c|c|c|c|c|}
\hline \multirow{3}{*}{$\begin{array}{l}\text { Population on } \\
1 / 1 / 2020\end{array}$} & & \multicolumn{6}{|c|}{ Registered length of stay on reference date } \\
\hline & & \multicolumn{2}{|c|}{$6-10$ years } & \multicolumn{4}{|c|}{$10+$ years } \\
\hline & Total & No. & $\%$ & No. & $\%$ & $\begin{array}{c}\% \text { all } \\
\text { for- } \\
\text { eigners }\end{array}$ & $\begin{array}{l}\text { \% total } \\
\text { popu- } \\
\text { lation }\end{array}$ \\
\hline Non-European citizens & 269,354 & 37,945 & 14.1 & 54,562 & 20.3 & 3.70 & 0.60 \\
\hline$\%$ of non-EU/EFTA & 38.0 & 42.0 & & 16.5 & & & \\
\hline Africa & 35,629 & 6,282 & 17.6 & 10,068 & 28.3 & 0.70 & 0.10 \\
\hline North America & 10,218 & 1,312 & 12.8 & 3,752 & 36.7 & 0.30 & 0.04 \\
\hline $\begin{array}{l}\text { Central + } \\
\text { South America }\end{array}$ & 12,955 & 2,055 & 15.9 & 4,388 & 33.9 & 0.30 & 0.05 \\
\hline Asia (w/o Turkey, & & & & & & & \\
\hline Cyprus) & 191,930 & 25,345 & 13.2 & 32,249 & 16.8 & 2.20 & 0.40 \\
\hline Syria & 51,441 & 2,361 & 4.6 & 682 & 1.3 & 0.05 & 0.01 \\
\hline Afghanistan & 43,585 & 7,964 & 18.3 & 3,457 & 7.9 & 0.20 & 0.04 \\
\hline Iran & 14,896 & 2,456 & 16.5 & 2,291 & 15.4 & 0.20 & 0.03 \\
\hline Iraq & 13,479 & 1,121 & 8.3 & 1,142 & 8.5 & 0.10 & 0.01 \\
\hline Australia + Oceania & 1,580 & 229 & 14.5 & 554 & 35.1 & 0.04 & 0.01 \\
\hline $\begin{array}{l}\text { Unknown, stateless, } \\
\text { unclear }\end{array}$ & 17,042 & 2,722 & 16.0 & 3,551 & 20.8 & 0.20 & 0.04 \\
\hline
\end{tabular}

Source: Statistics Austria, Population Statistics - Preliminary results for 1/1/2020.

In contrast, the share of people staying for more than ten years in Austria was significantly higher for citizens of other continents: at 10,000 out of 36,000 African citizens, it was 28.3 per cent. A further 6,300 members of this group ( 17.6 per cent) had lived there for between six and ten years. For the Americas as well as Australia and Oceania, about a third of these nationals fulfilled this criterion (all in all about 19,000 persons) and a further 15 per cent (10,000 people) had been resident for between six and ten years. Finally, among people with an unknown or unclear nationality, as well as for stateless persons, the share of those residing for ten years or more in Austria was about 20.8 per cent (concerning 3,600 people), while a further 16 per cent (some 2,700 people) had been in the country for six to ten years. 
After having explained in detail the composition of the foreign population resident in Austria for ten years or more, we now turn to the age structure of the foreign population in order to determine the demographic potential for the extension of naturalisations to underage family members.

\section{Age structure of the foreign population in Austria by length of residence}

The share of people under 18 on 01 January 2020 was a little higher among foreign citizens (20.3 per cent) than in the total population (18.3 per cent). In absolute numbers, some 300,000 foreign citizens were less than 18 years old, of whom 160,000 came from third countries and 140,000 from other EU and EFTA countries. The vast majority of underage foreigners ( 185,000 people or 61.2 per cent) had been in Austria for less than six years. Only about 18.9 per cent $(57,000)$ had been registered in Austria for between six and ten years and 19.8 per cent $(59,800)$ for ten years or more. If we consider the last two groups to be already included in the potential for ordinary or early naturalisation, the additional potential stemming from the extension of naturalisation can be set, at most, at 185,000 people or 2.1 per cent of the total population. Of these, 86,700 held EU/EFTA citizenship (1 per cent of the total population), while 97,800 were underage third-country nationals, who represented 1.1 per cent of the total population.

\section{Table 11.6. Underage population in Austria on 1/1/2020 by citizenship and length of registered stay}

\begin{tabular}{|c|c|c|c|c|c|}
\hline \multirow[t]{2}{*}{01.01 .2020} & \multicolumn{2}{|c|}{$\begin{array}{c}\text { Population aged under } \\
18 \text { years }\end{array}$} & \multicolumn{3}{|c|}{ Registered length of stay } \\
\hline & Total & $\%$ all ages & $<6$ years & $6-10$ years & $10+$ years \\
\hline All citizens & $1,628,649$ & 18.3 & 607,529 & 331,084 & 690,036 \\
\hline Foreign citizens & 301,288 & 20.3 & 184,509 & 57,002 & 59,777 \\
\hline$\%$ total population & 3.4 & & 2.1 & 0.6 & 0.7 \\
\hline EU/EFTA & 140,922 & 18.1 & 86,737 & 29,710 & 24,475 \\
\hline$\%$ total population & 1.6 & & 1.0 & 0.3 & 0.3 \\
\hline Non-EU/EFTA & 160,366 & 22.6 & 97,772 & 27,292 & 35,302 \\
\hline$\%$ total population & 1.8 & & 1.1 & 0.3 & 0.4 \\
\hline
\end{tabular}

Source: Statistics Austria, Population Statistics - Preliminary results for 1/1/2020.

If we now add this potential additional 98,000 underage third-country nationals residing less than six years in Austria (1.1 per cent of the total population) to the 330,000 people with third-country nationalities residing in Austria for more than ten years (3.7 per cent of the total population), we can conclude that the potential for naturalisation would be about 428,000 people. This represents 4.8 per cent of the total population, so that the naturalisation of all members with this potential would reduce the share of foreign 
citizens in Austria from 16.7 to 11.9 per cent. If we then add the underage EU/EFTA population residing in Austria for less than six years - about 87,000 (1 per cent of the total population) - to the roughly 265,000 EU/EFTA citizens eligible for naturalisation ( 3 per cent of the total population), we arrive at 352,000 people. This corresponds to 4 per cent of the total population. Naturalisation of all members of this second group would further reduce the share of foreigners in Austria to 7.9 per cent.

\section{Regional differences in the potential for naturalisation in Austria}

Because of the uneven distribution of the population with foreign citizenship within Austria, there are large regional differences in the potential for naturalisation in Austria. As can be seen in Figure 11.1, the share of foreign citizens residing in Austria for ten years or more varied greatly between the federal provinces. For Austria as a whole, the share of foreign citizens was 16.7 per cent on 01 January 2020, among whom the share of non-EU/EFTA citizens was 8 per cent. Around 6.7 per cent of the population were foreign citizens who had been living for ten years or more in Austria, while 3.7 per cent were non-EU/EFTA citizens who had lived for a similar time there.

\section{Figure 11.1. Share of foreign citizens (among them, non-EU/EFTA citizens) in Austria on $1 / 1 / 2020$ by federal province and length of registered stay (\%)}

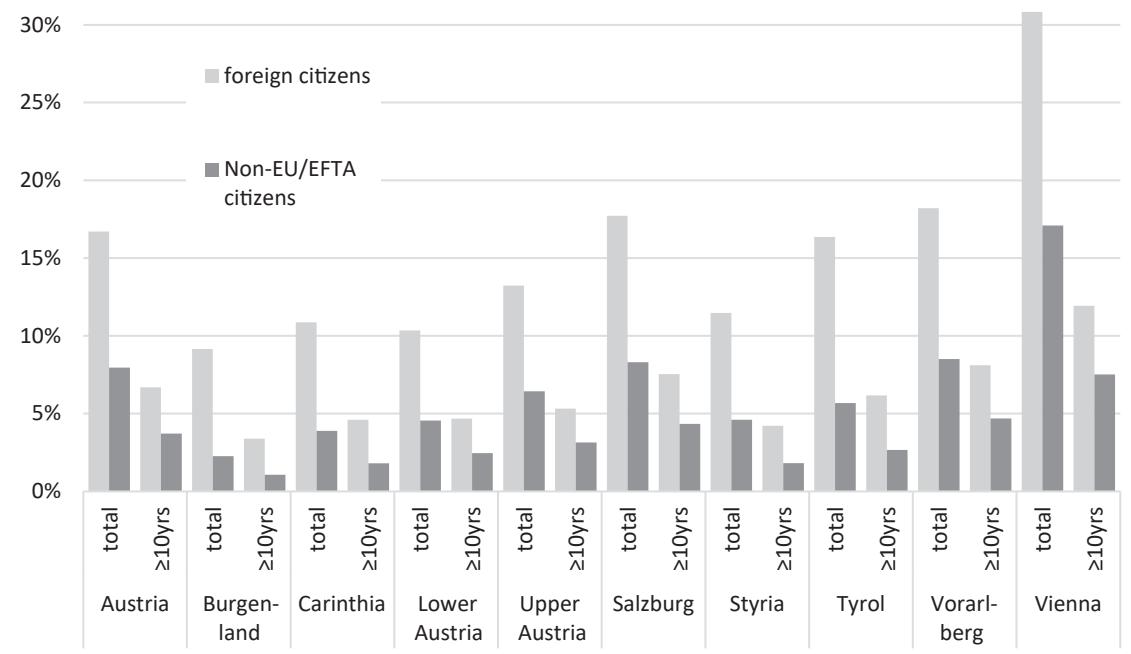

Source: STATISTICS AUSTRIA, Population Statistics - People residing ten years and more in AT are eligible for naturalisation. 
Four of the nine federal provinces had significantly lower shares of foreigners than the national average. The lowest shares were recorded (in ascending order) in Burgenland at 9.2 per cent, Lower Austria at 10.3, Carinthia at 10.9 and Styria at 11.5 per cent. Consequently, these federal provinces also had low shares of foreigners who had been living there for ten years or more - the lowest in Burgenland at 3.4 per cent, followed by Styria with 4.2 per cent, Carinthia at 4.6 per cent and Lower Austria at 4.7 per cent.

The corresponding share of non-EU/EFTA citizens was also quite low in these federal provinces: it was lowest again in Burgenland at 2.3 per cent of the total population, followed by Carinthia at 3.9, Lower Austria at 4.5 and Styria at 4.6 per cent. The share of non-EU/EFTA citizens resident for ten years or more was thus very low, starting at just 1.1 per cent of the population in Burgenland, followed by 1.8 per cent each in Carinthia and Styria and 2.5 per cent in Lower Austria.

Three federal provinces had roughly the same shares of foreign citizens as the national average. These were Tyrol at 16.4 per cent, Salzburg at 17.7 and Vorarlberg at 18.2. The share of foreigners residing for ten years or more in Austria was 6.2 per cent in Tyrol while, at 7.5 per cent in Salzburg and 8.1 per cent in Vorarlberg, it was higher than the national average of 6.7 per cent.

At 5.7 per cent, the share of non-EU/EFTA citizens in Tyrol was significantly lower than the national average (8 per cent), while Salzburg (8.3) and Vorarlberg (8.5) had shares largely corresponding to it. The share of non-EU/EFTA residents of ten years or more was 3.7 per cent for Austria as a whole but lower in Tyrol at 2.7 per cent and higher in Salzburg (4.3 per cent) and Vorarlberg (4.7).

Vienna is clearly distinct compared to all other federal provinces. At 30.8 per cent of the total population, it had by far the highest share of foreigners on 01 January 2020. Non-EU/EFTA citizens made up 17.1 per cent of the population. Yet, the share of foreign citizens residing there for ten years or more was only 11.9 per cent and that of non-EU/ EFTA citizens was 7.5 per cent. Thus, despite a very large population base of foreign citizens, even in Vienna the majority of foreigners were not (yet) potentially eligible for naturalisation. If all people with a sufficient length of stay were naturalised in Vienna, this would bring down the share of foreigners to around 18.9 per cent still. If all potentially eligible non-EU/EFTA citizens were to opt for naturalisation, the share of foreigners in Vienna would be reduced only to 23.3 per cent. Due to the concentration of recent migration inflows to Vienna, the share of foreigners would thus remain quite high, if even all potentially eligible migrants opted for naturalisation.

\section{Evolution of the potential for naturalisation in Austria since 2012}

Data on the length of registration of a residence in Austria have been available since the beginning of 2002. This means that the first date for which the number of people residing in Austria for ten years or more can be determined is 01 January 2012. Starting 
from this date it is interesting to analyse how the number of people who are potentially eligible for naturalisation in Austria has evolved over time.

Taking into account the changes in migration inflows to Austria which occurred in 2015 and 2016 (a much higher share of immigrants from non-EU/EFTA countries than both before and afterwards was noted during these two years), it is also useful to include 01 January 2015 in the analysis. The number of people present at different dates for between six and ten years - and thus potentially eligible for early naturalisation in Austria - has been omitted in this analysis, as such retrospective figures are not very relevant if the members had been living for ten years or more in Austria at the moment that it was carried out.

We start by looking at the evolution of the overall number of foreigners in Austria during the period 2012-2020. On 01 January 2012, there were about 950,000 foreign citizens registered in Austria, then representing 11.3 per cent of the total population. By 01 January 2015, their number had increased by about 200,000 (+20.5 per cent) to nearly 1.15 million. This increase was mainly driven by a rise in the number of EU/EFTA citizens. ${ }^{10}$ While there were roughly 450,000 EU/EFTA citizens living in Austria at the beginning of 2012 , three years later their number had risen to nearly 580,000 (+29.3 per cent). In contrast, the number of non-EU/EFTA citizens rose by only 60,000 (+12.6 per cent). In absolute figures, the number of EU/EFTA citizens outstripped that of non-EU/EFTA citizens during that period. The share of non-EU/EFTA citizens among foreigners in Austria consequently fell from 52.9 per cent on 01 January to 49.5 per cent on 01 January 2015.

Over the five years from 2015 to 2020, the number of foreign citizens in Austria rose by 341,000 people (+29.7 per cent), increasing from 1.15 million to 1.49 million. The number of EU/EFTA citizens increased by a third (200,000 people or +34.5 per cent) from 580,000 to 780,000 during this same period, while that of non-EU/EFTA citizens went up by a quarter ( 141,000 people or +24.9 per cent) from 570,000 to 710,000 . Thus, even though there were large increases in immigration flows from non-EU/EFTA countries in 2015 and 2016, these were offset by even larger immigration flows of EU/EFTA citizens occurring constantly from 2015 to 2020.

The development of the number of foreign citizens who had remained in Austria for more than ten years overall followed the same pattern as that of the foreign population as a whole, albeit less pronounced. On 01 January 2012 there were about 375,000 foreign citizens who had been living ten years or more in Austria. By 01 January 2015 , their number had increased by a quarter $(94,000$ or +25.2 per cent) to nearly 470,000. Among this group there were more non-EU/EFTA than EU/EFTA citizens. On 01 January 2012, the number of non-EU/EFTA citizens residing in Austria for ten years

10 The numbers have been corrected for the accession of Croatia to the EU on 01 July 2014. For the purposes of comparison, Croatia is also included under EU/EFTA countries on 01 January 2012. 
or more was about 220,000, compared to just over 150,000 EU/EFTA citizens. Over the following three years their number increased by nearly 60,000 ( +26.9 per cent) to 280,000 for non-EU/EFTA citizens but only by 35,000 (+22.8 per cent) to nearly 190,000 for EU/EFTA citizens.

\section{Figure 11.2. Evolution of foreign population in AT 2012-2020 by selected citizen- ship and length of stay}

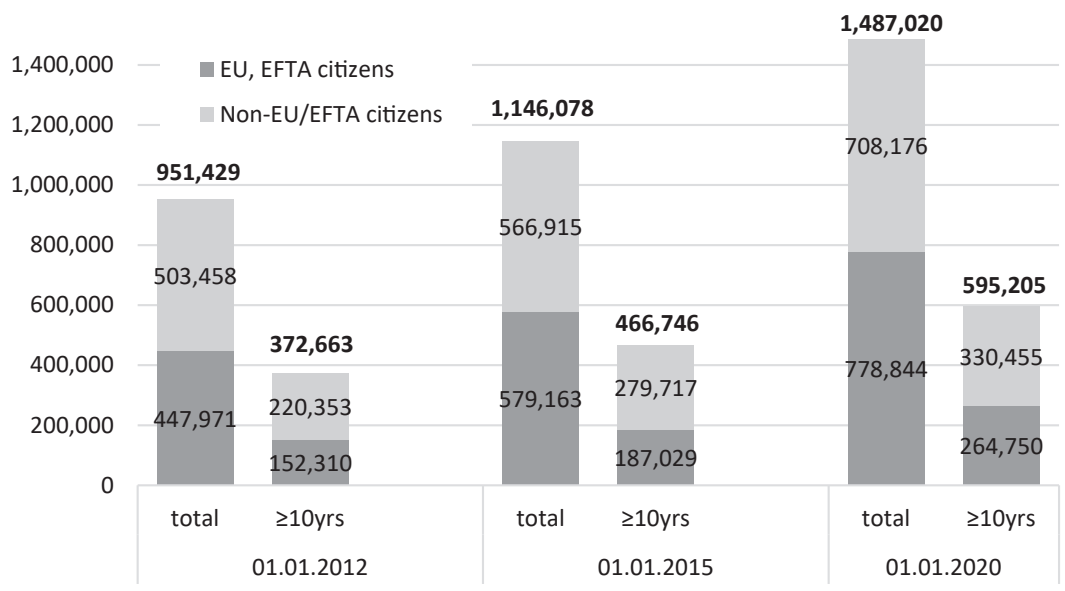

Source: STATISTICS AUSTRIA, Population Statistics - Preliminary figures for 1/1/2020.

The further evolution from 2015 to 2020 was as follows: the number of EU/EFTA citizens grew by about 78,000 (+41.6 per cent) to 265,000 during this period. This large increase reflects the strong inflows of immigrants from Central European EU member states after the lifting of labour-market restrictions in Austria in 2012. The number of non-EU/EFTA citizens staying for ten years or more rose only by 50,000 (+18.1 per cent) to 330,000 over the same five years. This is clearly linked to quite low numbers of immigrants from non-EU/EFTA countries in the years after the amendment of the Austrian Foreigners Residence Act in 2006, which set out several restrictions to the immigration of non-EU/EFTA citizens to Austria.

We now turn to the evolution of the share of foreigners and their different sub-groups in the total population in the period 2012-2020. The share of the overall foreign population in Austria progressed from 11.3 per cent in 2012 to 13.3 per cent in 2015 and to 16.7 per cent in 2020. This translates into 0.67 per cent annually for the period 2012-2015 and 0.68 per cent for 2015-2020. Despite the massive inflows of 2015 and 2016, there is not much overall visible difference between the two periods.

For EU/EFTA citizens, the share evolved from 5.3 per cent in 2012 to 6.7 in 2015 and 8.7 in 2020. This corresponds to 0.47 per cent annually for the period 2012-2015 and 0.4 
per cent for 2015-2020. Non-EU/EFTA citizens made up 6 per cent of the population in 2015 , followed by 6.6 per cent in 2015 and 8 per cent in 2020 . For the annual increases, this translates into 0.2 per cent during 2012-2015 and 0.3 for 2015-2020.

\section{Figure 11.3. Evolution of share of foreign population in AT 2012-2020 by length of stay (\%)}

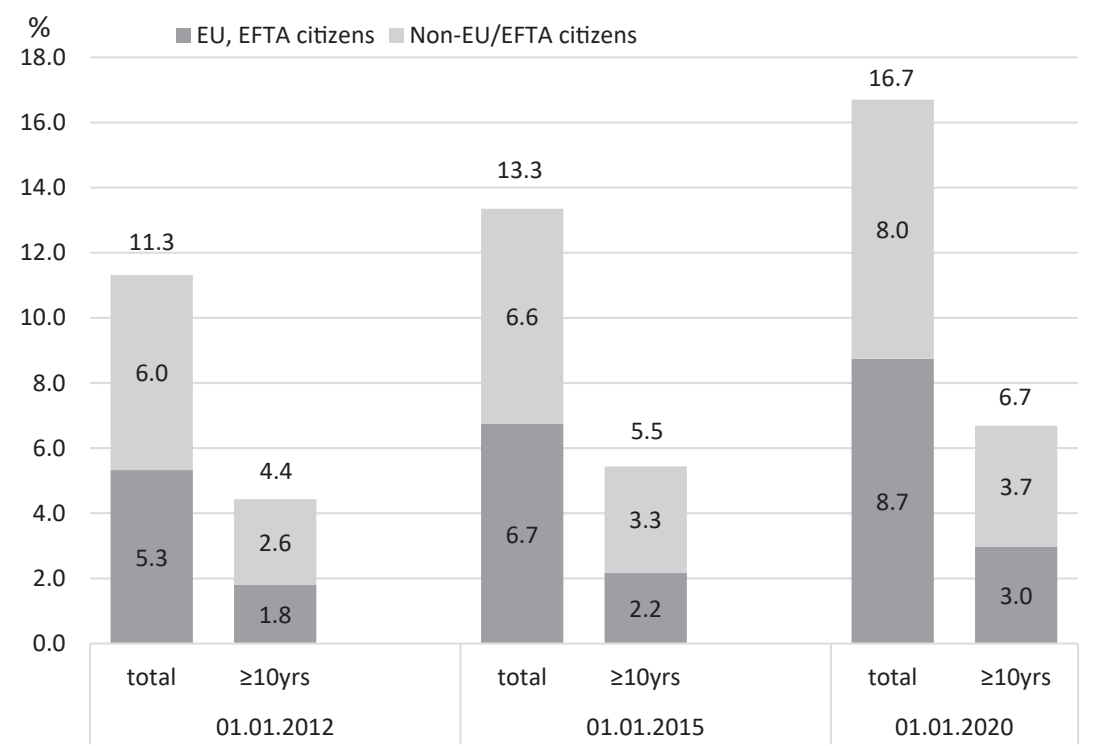

Source: STATISTICS AUSTRIA, Population Statistics - Preliminary figures for 1/1/2020.

Turning now to the share, in the total population, of foreign citizens resident for ten years or more in Austria, this was 4.4 per cent on 01 January 2012, followed by 5.5 per cent at the beginning of 2015 and 6.7 per cent at the start of 2020. The annual increase was thus 0.4 per cent in 2012-2015 and 0.2 in 2015-2020. These figures clearly reflect the overall low immigration figures to Austria from 2005 to 2010.

The picture gets a little more diverse if we again split the share of foreigners for EU/ EFTA and non-EU/EFTA citizens. In 2012, just 1.8 per cent of the population were EU/EFTA citizens who had been residing in Austria for ten years or more. In 2015, their share had progressed to 2.2 per cent and by 2020 to 3 per cent. In terms of annual growth, this means 0.1 per cent for 2012-2015 and 0.2 per cent for 2015-2020.

For non-EU/EFTA citizens living in Austria for ten years or more the share in the total population was 2.6 per cent in 2012, 3.3 in 2015 and 3.7 in 2020. This translates into a growth of 0.2 per cent annually for 2012-2015 but less than 0.1 per cent annually for 2015-2020. 


\section{Interim conclusion: the evolution of the foreigners' share, if the potential for naturalisation had been fully exploited}

Summing up the data thus far, we can say that, in 2012, there were about 375,000 people who were potentially eligible for naturalisation, of whom some 220,000 non-EU/EFTA citizens were more likely to acquire Austrian citizenship. This corresponds to 4.4 and 2.6 per cent of the then-total population respectively. If all such potential had been realised, the share of the foreign population would have dropped from 11.7 to 7.3 per cent of the population or to 9.1 per cent if only non-EU/EFTA citizens were counted as likely candidates for naturalisation.

In 2015, the number of potential candidates for accession to Austrian citizenship had increased to around 470,000 people, of whom 280,000 were non-EU/EFTA citizens. This translates into 5.5 and 3.3 per cent of the then-total population respectively. Realising this full potential for naturalisation would have reduced the share of foreigners in the total population from 13.3 per cent to 7.8 or 10 per cent. Compared to 2012 , the increase in the foreign population would therefore have been reduced from 1.6 to 0.5 per cent or 0.9 per cent if only non-EU/EFTA citizens were counted.

In 2020, the number of foreign citizens resident in Austria for ten years or more had risen to nearly 600,000 people, of whom some 330,000 were non-EU/EFTA citizens. In terms of the overall population, this accounted for 6.7 and 3.7 per cent respectively. If all those potentially eligible for naturalisation had used this option, the share of foreigners would have dropped from 16.7 to just 10 or 13 per cent of the total population. In relation to 2015 , the share of the foreign population in these cases would have been reduced from 3.4 to 2.2 per cent or 3 per cent for the non-EU/EFTA population only.

Comparing the two periods - 2012-2015 and 2015-2020 - reveals that current legal conditions for naturalisation entail similar quantities for the potentially possible reduction of the foreign population through naturalisation. The reduction may have been a maximum of 1.2 percentage points for the overall foreign population and a maximum of 0.7 for the non-EU/EFTA population only. This situation may change at some point in the mid-2020s, once many of the immigrants from 2015 and 2016 reach a length of residence in Austria of ten years or more. Otherwise, the dominance of intra-EU/EFTA immigration to Austria means that naturalisation rates are not very likely to go up for the foreseeable future, except in unexpected circumstances. ${ }^{11}$

\section{Naturalisation propensity in Austria 2012-2019}

This brings us to the final point of the analysis. After defining the potential numbers of people being naturalised, we can compare the evolution of these figures with the

11 E.g. if a process of disintegration of the EU/EFTA occurs. 
actual naturalisations recorded in Austria during the period 2012-2019. From this, we can approximate the share of people actually being naturalised among the population recently eligible for naturalisation in Austria (i.e. the propensity for naturalisation among the different sub-groups of the foreign population in Austria).

As we have seen in the previous section, the number of foreigners staying for ten years or more in Austria and thus being potentially eligible for naturalisation increased by 94,083 during the three years between 01 January 2012 and 01 January 2015. During this period there were 21,967 naturalisations recorded in Austria. ${ }^{12}$ We can add together these two figures to determine the potential number of naturalisations during this period. If naturalisations actually occurring are set in relation to this overall figure, we arrive at a naturalisation rate of 18.9 per cent. This means that about one fifth of the people who are potentially newly eligible for naturalisation in Austria during 2012-2015 have actually been granted Austrian citizenship during this period.

\section{Table 11.7. Evolution of foreign population in Austria staying ten years or more in Austria 2012-2020 and naturalisations in Austria, 2012-2020}

\begin{tabular}{|c|c|c|c|}
\hline & $\begin{array}{l}\text { Foreign } \\
\text { citizens }\end{array}$ & $\begin{array}{r}\text { EU, EFTA } \\
\text { citizens }\end{array}$ & $\begin{array}{l}\text { Non-EFTA } \\
\text { citizens }\end{array}$ \\
\hline 01.01 .2012 & 372,663 & 152,310 & 220,353 \\
\hline 01.01 .2015 & 466,746 & 187,029 & 279,717 \\
\hline in difference & 94,083 & 34,719 & 59,364 \\
\hline 그 naturalisations & 21,967 & 3,436 & 18,531 \\
\hline difference incl. naturalisations & 116,050 & 38,155 & 77,895 \\
\hline$\stackrel{\sim}{\text { naturalisation rate } \%}$ & 18.9 & 9.0 & 23.8 \\
\hline 01.01 .2020 & 595,205 & 264,750 & 330,455 \\
\hline 워 difference & 128,459 & 77,721 & 50,738 \\
\hline naturalisations & 45,654 & 7,892 & 37,762 \\
\hline difference incl. naturalisations & 174,113 & 85,613 & 88,500 \\
\hline naturalisation rate $\%$ & 26.2 & 9.2 & 42.7 \\
\hline
\end{tabular}

Source: Statistics Austria, Naturalisation Statistics 2012-2019; Population Statistics for 1/1/2012, $1 / 1 / 2015$ and $1 / 1 / 2020$ - Preliminary results for $1 / 1 / 2020$.

As can be expected from the legal conditions mentioned above, there are marked differences in naturalisation rates for EU/EFTA-citizens on the one hand and non-EU/EFTA citizens on the other. While less than one tenth (9 per cent) of the newly eligible EU/EFTA citizens actually gained Austrian citizenship during 2012-2015, nearly a quarter (23.8 per cent) of the newly eligible non-EU/EFTA citizens did so.

12 Only cases of people residing in Austria were included in this count. There were a further 251 naturalisations of persons residing abroad - 99 of these covered former EU/EFTA citizens and 152 covered former non-EU/EFTA citizens. 
During the period 2015-2019, the number of annual naturalisations in Austria increased slightly to reach a total of $45,654^{13}$ being recorded over these five years. The overall naturalisation rate was higher than in the previous period, increasing to more than a quarter (26.2 per cent) of newly eligible foreigners. As the naturalisation rate for EU/EFTA citizens remained quite stable, at less than one tenth (9.2 per cent), the increase was exclusively due to a significantly higher share of non-EU/EFTA citizens (42.7 per cent) becoming newly eligible. Yet, even these higher rates only represent a minority of the newly eligible population.

This underlines that there ought to be significant other factors contributing to the low naturalisation rates in Austria. ${ }^{14}$ Reichel (2011) and Bauböck et al. (2013) note that actual naturalisation numbers are determined by several factors. Firstly, the income situation of migrants plays an important role, both in the need for them to earn over a certain threshold as a prerequisite for naturalisation and in relation to being able to afford the cost of high naturalisation fees in Austria. Secondly, individual life plans related to the family extension of naturalisation or return-migration plans (often at retirement) certainly influence the decision to naturalise and at which point in time. Thirdly, migrants may maintain an emotional attachment to their citizenship of origin or have an instrumental interest in keeping it - e.g. to retain the possibility of real-estate ownership or inheritance in the country of origin, which is often prohibited for non-citizens. Finally, naturalisation figures are determined not only by eligibility and propensity but also by administrative decisions to grant or deny citizenship. This means that withdrawn applications and rejection rates should also be taken into account when interpreting actual naturalisation numbers, although official data on these are missing in Austria.

We may thus conclude that gaining Austrian citizenship is primarily attractive for nonEU/EFTA citizens and much less so for EU/EFTA citizens. Yet, even though the numbers of non-EU/EFTA immigrants to Austria rose briefly during 2015 and 2016, we may expect only a limited demand for naturalisation in the coming years. Many of the arrivals of 2015 and 2016 either do not fulfil the other prerequisites for naturalisation or lack the financial means to cover the considerable fees and other costs of this procedure.

\section{Summary and conclusions}

In this study, we have examined only one of the pre-requisites for naturalisation under Austrian law - the length of continuous residence in the country. As an approximation, calculations have been based on the criterion of length of stay of ten years or more in

13 Between 2015 and 2019 there were a further 564 naturalisations pertaining to people living abroad; of these 176 covered former EU/EFTA-citizens and 388 former non-EU/EFTA citizens.

14 For a general discussion of immigrants' propensity to naturalise, see also Chapter 2 by Max Haller in this volume. 
Austria. Early access to naturalisation under certain conditions after six years of residence would, for most sub-groups of foreign citizens, add a further half the number of potential members.

We have argued that there is little incentive for EU/EFTA citizens to apply for citizenship, as they largely have the same rights as nationals (except for voting in regional and national elections) and are generally disinclined to renounce their current citizenship. Low naturalisation rates of about 1 per cent of residents or about 9 per cent of people being newly eligible to acquire Austrian citizenship confirm that this not a relevant interest for most EU/EFTA citizens residing there. The size of the eligible EU/EFTA citizen population on 01 January 2020 was 265,000 (3 per cent of the total population) based on a residence of ten years or more, adding 134,000 (1.5 per cent) if also including people with six to ten years of residence in Austria.

Among non-EU/EFTA citizens, the propensity for naturalisation was much higher and increased over time from about a quarter (24 per cent) in 2012-2015 to more than two-fifths (43 per cent) in 2015-2019. Overall, about 330,000 non-EU/EFTA citizens were resident in Austria for ten years or more on 01 January 2020 - 3.7 per cent of the total population. A further 90,000 non-EU/EFTA citizens potentially qualify for early naturalisation, as they have been living in Austria between six and ten years. This corresponds to a further 1 per cent of the population. The naturalisation of all non-EU/EFTA citizens with a residence of ten years or more in Austria on 01 January 2020 would reduce the share of foreign citizens in Austria from 16.7 to 13 per cent. This would roughly offset the increase in the foreign population in Austria during the last five years. The naturalisation of eligible EU/EFTA citizens would further reduce the foreigners' share in the population to 10 per cent. If persons with a residence of six to ten years were also all naturalised, the percentage of foreigners would drop further to 7.5 per cent, less than half the actual share recorded on 01 January 2020.

The underage population of non-EU/EFTA citizens living less than six years in Austria accounts for 98,000 people or 1.1 per cent of the population. Minors with non-EU/EFTA citizenship resident for six to ten years amount to 27,000 people or 0.3 per cent of the total population.

At the regional level, Vienna has the highest potential for naturalisation, followed by Vorarlberg and Salzburg, if only non-EU/EFTA citizens resident for ten years or more are counted. This differs a little from the ranking of federal provinces with regards to the overall share of foreigners, where Tyrol and Upper Austria also rank highly.

Compared to the potential figures, the real naturalisation figures are very low, especially when compared at the European level. Austria is, in this respect, similar to neighbouring Czechia, Slovakia and Slovenia - which, however, all have much smaller foreign population stocks. Germany and Switzerland, which have similar shares of foreign citizens to Austria, have somewhat higher naturalisations rates, even though these are still low when compared to Sweden, the Netherlands or France. 
Low naturalisation rates in Austria may thus well be the result of the many other prerequisites to be fulfilled apart from six or ten years of residence. Not the least among these is the strong restriction of dual citizenship under Austrian law. However, naturalisation rates seem to be strongly influenced by economic requirements, as Stadlmair (2017) found out in his comparative study of naturalisation practises among EU member states. Thus, the decisive factor here may well be Austria's very demanding economic preconditions for naturalisation. As discussed at the beginning, a very substantial part (about a quarter) of all Austrian employees do not earn enough from their gainful employment to fulfil these conditions. Further research is needed to determine to what extent certain nationalities are affected by these income requirements. In a second step this could then be linked to the different propensities for naturalisation observed among the various groups of foreigners living in Austria.

\section{References}

Bauböck, R., Honohan, I., Huddleston, T., Hutcheson, D., Shaw, J. and Vink, M.P. 2013. Access to Citizenship and its Impact on Immigrant Integration: European Summary and Standards. Florence: European University Institute. Available at: https://cadmus.eui. eu/bitstream/handle/1814/29828/AccesstoCitizenshipanditsImpactonlmmigrantIntegration.pdf?sequence=1 (accessed 12 December 2020).

Labussière, M. and Vink, M. 2020. The intergenerational impact of naturalisation reforms: the citizenship status of children of immigrants in the Netherlands, 1995-2016, Journal of Ethnic and Migration Studies, 46(13): 2742-2763.

Peters, F., Vink, M. and Schmeets, H. 2016. The ecology of immigrant naturalisation: a life course approach in the context of institutional conditions, Journal of Ethnic and Migration Studies, 42(3): 359-381.

Reichel, D. 2011. Do Legal Regulations Hinder Naturalisation? Citizenship Policies and Naturalisation Rates in Europe. Florence: European University Institute, EUI Working Paper RSCAS.

Reichel, D. 2012. Regulating Political Incorporation of Immigrants: Naturalisation Rates in Europe. Vienna: International Centre for Migration Policy Development, ICMPD Working Paper No. 4. Available at: http://research.icmpd.org/fileadmin/Research-Website/ Publications/working_papers/Reichel_Naturalisation_Rates_Europe_2012.pdf (accessed 13 December 2020).

Rössl, I. and Valchars, G. 2019. Einbürgerung, Einkommen und Geschlecht. Hürden beim Zugang zum Wahlrecht, in Herausgeberinnenkollektiv Blaustrumpf Ahoi! (eds) "Sie Meinen es Politisch!" 100 Jahre Frauenwahlrecht in Österreich. Vienna: Löcker, 301-312. Stadlmair, J. 2017. Which policies matter? Explaining naturalisation rates using disaggregated policy data, OZP, Austrian Journal of Political Science, 46(1): 59-72. 
Statistics Austria 2019. Annual Personal Income Statistics. Available at: http://www.statistik.at/wcm/idc/idcplg?ldcService=GET_NATIVE_FILE\&RevisionSelectionMethod=LatestReleased\&dDocName=019349 (accessed 13 December 2020).

Wagner, A. 2019. Ist Gleichheit käuflich? Staatsbürgerinnen und -bürger aus Sicht der Rechtsordnung, Stimme: Zeitschrift für Minderheiten, 111: 8-10. Available at: https:// stimme.minderheiten.at/wordpress/wp-content/uploads/sites/3/2019/06/st111_ web_s08-10.pdf (accessed 13 December 2020).

Wanner, P. and Galeano, J. 2020. Crude and Standardised Rates of Ordinary Naturalisation in Swiss Municipalities: New Interactive Maps. Neuchâtel: University of Neuchâtel.

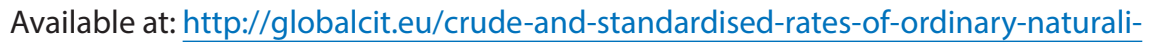
sation-in-swiss-municipalities-new-interactive-maps/ (accessed 13 December 2020). 


\title{
Chapter 12
}

\section{Does Citizenship Promote Integration? An Austrian Case Study of Immigrants from Former Yugoslavia and Turkey}

\author{
Raimund Haindorfer, Department of Sociology, University of Salzburg \\ Max Haller, Professor Emeritus, Department of Sociology, University of Graz/ \\ Austrian Academy of Sciences, Vienna
}

\begin{abstract}
This paper addresses the question of whether or not naturalisation promotes the integration of immigrants. The empirical basis for the study is a standardised survey comprising 600 immigrants from Turkey and the former Yugoslavia living in Austria. We investigate the differences in four aspects of (social) integration: structural integration (access to the labour market), social integration (the building-up of social relations with members of the host society), cultural integration (acquiring German-language skills and support for modern gender-role attitudes) and identificative integration (strengthening the feeling of belonging to Austria). Our hypothesis is that the attainment of citizenship supports all of these. Immigrants who became Austrian citizens are compared with those who did not - across indicators of all four aspects of integration. In multivariate regression analyses, we also include migration experience (migration background and generation as well as the length of stay in Austria) as explanatory and socio-demographic characteristics (gender, age, educational level) as control variables. The findings show the expected effects in most regards. In addition, a significant interaction effect emerges between migration background and gender, whereby Turkish women have fewer chances of finding employment than ex-Yugoslavian women in comparison with men of the same nationalities as the women. In the conclusion, we point out the methodological limitations of the study and indicate avenues for further research, both in theoretical terms and concerning empirical research designs.
\end{abstract}

\section{Introduction}

Citizenship is a basic resource of a person in modern societies. It provides the unlimited right to residence in a country, full access to political participation and access to all welfare-state benefits, including for persons who are not active economically. Therefore, the naturalisation of immigrants is connected with several important advantages (see Blatter, Sochin D'Elia and Buess 2018). The state grants the unconditional right to residence and provides diplomatic support in foreign countries, guaranteeing that the person will be 
able to return to the country of origin whenever he or she wishes. In addition, citizenship helps decisively in many socio-economic aspects. This also applies, albeit to a lesser degree, to citizens of other EU states who already have a right to settle down and work anywhere in the European Union. What is also very important is that, through naturalisation, the immigrants acquire full political rights to participate, so they can feed their attitudes and interests into the political process. This also applies to immigrants from other EU member countries who, as "denizens", ' have the most social and economic rights but not full political rights and - as non-citizens - also experience several forms of open and hidden discrimination. In the EU, however, such discrimination applies particularly to third-country nationals (citizens of non-EU member states) from non-Western countries (see OECD 2015; for discrimination against immigrants in general, see Shadow Report 2017). If large numbers of immigrants are not enfranchised, this affects the legitimacy of elections and the political system in general because the electorate does not reflect the whole social structure and areas which are exempt from democratic politics emerge (Stadlmair 2018a; Valchars 2018).

The situation of immigrants without citizenship is particularly relevant in the case of Austria for two reasons. First, because Austria has become an "immigration country" since the mid-1960s (Fassmann and Münz 1995). In 1961, just 1.4 per cent of the resident population were foreigners (non-Austrian citizens); by 2017, the proportion had risen to 15.3 per cent or 1.3 million people. This is one of the highest proportions in the European Union; in Vienna alone, 30 per cent of the resident population are foreigners. The total number of residents with a migration background in Austria was around 1.9 million in 2017 - again, nearly 30 per cent of the population (Haller 2019; Statistik Austria 2018). The second reason why the situation of immigrants without national citizenship is particularly important in the case of Austria is that naturalisation has been made more difficult in recent times. In a comparison between eight European countries in the mid1990s, Austria had the highest threshold concerning residence permits, access to the labour market, family reunification and the legal rights of second-generation immigrants (Çınar, Hofinger and Waldrauch 1995; MIPEX 2015; Valchars 2018). The legal hurdles for naturalisation have been strengthened (as in many other countries) - in addition to the restrictions (quotas) on immigration from the 1990s on; today, Austrian citizenship law is one of the most restrictive in Europe (Karasz and Perchinig 2013; Stadlmair 2018b; Valchars 2018). Two scholars wrote on this topic in 2013: "... it appears that [Austrian] citizenship law has been and is still being instrumentalized to uphold the idea of a citizenship that ought to be a 'precious' good and 'needs to be earned'" (Stern and Valchars 2013,

1 In biology, the term "denizen" refers to an animal or plant living in a specific place; historically, the concept referred to a privileged status of foreigners granted by the English monarchy; in the social sciences, it means a foreigner with a right to permanent settlement and, maybe, some other socio-economic rights. 
46). From the perspective of the Austrian government, an integration policy requiring many preconditions (such as long-term residence, good knowledge of German and a steady and considerable income) has the advantage that those who attain citizenship are already better integrated (Koopmans 2015).

\section{Literature review and hypotheses}

Naturalisation - the acquisition of citizenship after birth based on an individual application - can have several positive effects on integration. As mentioned above, it provides full access to welfare-state benefits and state services, it supports access to the labour and housing markets by reducing open and hidden discrimination and it bestows the right of access to all jobs in public administration. For employers, it indicates that a person is already well integrated and committed to remaining in the country and it reduces their administrative costs. The main reason why the effect of naturalisation could be weak or even absent is a selection effect: naturalisation might only be a final step of integration for those immigrants who already made previous successful efforts to integrate. For Sweden, Scott (2008) and Engdahl (2011) came to this conclusion.

Several studies have been carried out about the relevance of naturalisation for the process of integration (see Peters and Vink 2016 for an overview). For several North American and European countries, Bratsberg, Ragan and Nasir (2002) and Helgertz, Bevelander and Tegunimataka (2014) found a positive association between citizenship acquisition and labour-market integration. For the Netherlands, a country with a very high number of naturalisations, Bevelander and Veenman (2006a) found a positive effect on labour-market integration and income, except for Mediterranean immigrants. For immigrants from Morocco and Turkey, no positive effect of naturalisation on employment and cultural integration was found (Bevelander and Veenman 2006b). For Germany, Steinhardt (2012) re-analysed a large, representative employment survey (including 60,000 persons, a 2 per cent sample of the employed population) in both a cross-sectional and a panel (longitudinal) design. Steinhardt (2012) also found a significant positive effect of naturalisation on wages, which occurred in two ways: as an immediate effect of naturalisation and as an accelerated wage growth in the years after naturalisation. The OECD held a comprehensive seminar on this topic with participants from many countries; in 2008, in the whole OECD area, the number of naturalisations exceeded 2 million people (OECD 2011). The result of the presentations of data from many European and North American countries at this seminar was that naturalisation enhances labour-market integration, particularly access to higher-skilled occupations and the public sector. Hainmüller, Hangartner and Pietrantuono (2017) detected that naturalisation fosters political participation in Switzerland; Just and Anderson (2012) found the same for many European countries. However, Bartram (2019), in a panel study, concluded that, in Britain, the effect of naturalisation was absent or even negative - 
people who became British citizens later reported less interest in politics and were less likely to participate in organisations. He explains this divergent finding by the fact that both the strict requirements for naturalisation and the mandatory citizenship ceremony alienate those new citizens who do not already feel genuinely British before naturalisation. In our study, we compare two groups of immigrants to Austria from the former Yugoslavia and Turkey - one group who had attained Austrian citizenship and another who had not. The study is methodically limited regarding the identification of a true causal relationship between citizenship and integration because we did not conduct a panel study investigating immigrants both before and after naturalisation. However, in comparison with prior research, this study has two strengths. First, we not only investigate the effects of naturalisation on economic outcomes such as labour-market access and income but, instead, include three additional aspects of integration (social, cultural and identificative integration). Second, we can compare two well-defined, different groups of immigrants - those from the former Yugoslavia and those from Turkey. Here, we can rely on a special survey in Austria which has been carried out and analysed intensively regarding other aspects by a group of sociologists (Aschauer, Beham-Rabanser, Bodi-Fernandez, Haller and Muckenhuber 2019). Based on general considerations about the relevance of citizenship for integration outcomes and the relevant research evidence presented, we propose the following two sets of hypotheses on the effect of naturalisation and the migration experience on integration (1 and 2) and include socio-demographic characteristics (3) as controls.

\subsection{The naturalisation effect}

The first and basic hypothesis is that naturalisation will have a positive effect on integration outcomes in the host society in all its four aspects - i.e. structural, social, cultural and identificative integration. These four dimensions can be conceived as crucial dimensions of integration (Esser 2009; Heckmann 2015). More precisely, immigrants with Austrian citizenship in comparison to those without it will have a greater likelihood of being employed (structural integration); they will have more contacts with Austrians and will agree more frequently to interethnic marriages (social integration); they will have better German-language skills and will more frequently reject traditional gender roles (cultural integration); they will have a more pronounced sense of national belonging to Austria and will be more interested in events in the host society (identificative integration).

\subsection{The migration experience}

The integration achievements of immigrants may also depend on their specific migration background, generation and length of stay in the host society.

a. Migration background: prior analysis of the SSÖ Migration Survey 2016 showed that immigrants from the former Yugoslavia are generally better integrated and identify 
more frequently with Austria than immigrants from Turkey; however, in both samples there was a trend towards an increase in integration in line with the duration of residence in Austria (Aschauer et al. 2019). One main reason for these findings is certainly that people from ex-Yugoslavia are more similar to autochthonous Austrians in religious (most of them are Christians) and linguistic terms, while nearly all immigrants from Turkey are Muslims and the Turkish language is also quite different from Indo-European languages. Yugoslavia has also had a higher GDP per capita and was under the influence of communism for several decades so that traditional social attitudes will be less prevalent there than in Turkey. Additional reasons for diverging integration outcomes among the two groups of immigrants in Austria are related to the recent socio-economic and political situation in the two countries of origin. First, the economic and political situation after the downfall of Yugoslavia was (and in some ways still is) somewhat worse than in Turkey; around 100,000 people fled from the wars in Croatia, Bosnia-Herzegovina and Kosovo to Austria in the 1990s. They might have been comparatively happy to find shelter in Austria and therefore quite ready to integrate. Second, immigrants from Turkey are politically and emotionally more connected to their country of origin (Müller-Kmet and Bodi-Fernandez 2019). They are also highly exposed to political influence and pressure from the Turkish government and the media as well as from compatriots living in Austria (Aschauer et al. 2019; Riegler 2000). Based on these considerations and empirical findings, we expect a significant difference in integration outcomes between immigrants from the former Yugoslavia and those from Turkey; the first will be better integrated than the latter.

b. Migration generation and length of stay in Austria: as mentioned above, a prior study found a trend towards an increase of integration according to the duration of residence in Austria (Aschauer et al. 2019). This empirical finding is also reflected in many other studies on the integration of immigrants (Heckmann 2015; Koopmans 2015) and in the theoretical literature that argues that integration can take time (Castles, Korac, Vasta and Vertovec 2002; Esser 2009). Against this background, we suggest that the second generation of immigrants (in comparison with the first generation) as well as immigrants with a longer length of stay in Austria do show better integration outcomes. It is important to point out that, by including the variables of migration generation and length of stay in Austria in our analyses, we also control for the temporal differences between the immigrants in the survey that probably influence both their integration achievements and their probability of gaining Austrian citizenship.

\subsection{Socio-demographic characteristics}

We expect that several of these characteristics are relevant for the degree of integration and possibly also for the effect of naturalisation on integration. As these are probably con- 
founder variables (Frank 2000) in the relationship between citizenship and integration, it is important to adjust for them in the multivariate analyses; we include respondents' gender, age and educational level.

\section{Data and methods of analysis}

\subsection{The SSÖ Migration Survey 2016}

The empirical basis for our analysis is the SSÖ Migration Survey $2016^{2}$ - an additional survey on migrants in the course of the data collection for the fourth Social Survey Austria (SSÖ) in 2016. The focus was on the two biggest non-German-speaking immigration groups - i.e. those from the former Yugoslavia (ex-Yugoslavia) and Turkey. The SSÖ Migration Survey 2016 was carried out by the Institute for Empirical Social Research (IFES) in Vienna. The IFES used an onomastic (name-based) sampling procedure based on the official telephone directories as there are no complete directories for persons with a migration background in Austria and those of the second and third generations who belong to the defined target group. Sampling based on country-specific names from the official telephone directory (the onomastic method) is deemed to be a feasible way of attaining a good sample of ethnic minorities. The survey was conducted by Computer Assisted Telephone Interviews (CATI) in German or in the language of the immigrants. ${ }^{3}$ In total, 600 interviews with persons with a migration background from Turkey $(n=300)$ and ex-Yugoslavia $(n=300)$ resident in Austria was able to be realised (cf. Bodi-Fernandez, Hadler and Meyer 2019, 313-318). However, the SSÖ Migration Survey 2016 cannot be considered as representative, as several biases can be seen in comparison to the Austrian micro census - for instance, its interviewees are clearly better qualified and more often employed. As there exist no official weighting data for the target groups of the SSÖ survey, no weighting could be carried out (therefore, all analyses in the present article are based on unweighted data). However, representativity is no precondition for the testing of hypotheses on relationships between variables within the survey. Therefore, although we cannot draw inferences on the statistical distribution of our variables in the total migrant population, the sample can be considered as a valid basis for investigating group differences and relationships between variables regarding the attitudes and characteristics of immigrants (cf. Bodi-Fernandez et al. 2019, 325-326).

2 For data access we would like to thank Lorenz Makula and Otto Bodi-Fernandez from AUSSDA - The Austrian Social Science Data Archive (https://aussda.at/en/).

3 The respondents could choose between the German, Turkish or Croatian/Serbian/Bosnian languages. 


\subsection{Dependent variables: structural, social, cultural and identificative integration}

In Table 12.1 the descriptive statistics for the variables of the regression analyses are presented, both for the total sample and separately for the groups with a migration background from ex-Yugoslavia (YUG) and Turkey (TUR) who hold (CIT) and do not hold (N-CIT) Austrian citizenship. The following variables were used for the operationalisation of the main indicators:

- Structural integration: a dichotomous variable measuring whether or not the respondents are currently employed; ${ }^{4}$

- Social integration is measured through two variables - first, by a variable on the share of Austrians in social contact ( $1=$ nobody, $2=$ a few, $3=$ about half, $4=$ most, $5=$ all) ${ }^{5}$ secondly, by a question on the agreement on potential interethnic marriages ( $1=$ no way, 4 = yes, definitely). The latter variable is a mean score of two items that were, on the one hand, asking if it would be okay if the person's son (or if he or she had a son) married an Austrian woman and, on the other, asking if it would be okay if the person's daughter (or if he or she had a daughter) married an Austrian man ( $1=$ in no way, 2 = rather not, 3 = perhaps, 4 =yes, definitely). The reliability of the scale was sufficiently high (Cronbachs Alpha $=0.9$ ).

- Cultural integration: immigrants' German-language skills (1 = very bad/not at all, $5=$ very good) which also is a mean score of two items comprising language skills in terms of the ability to (a) understand Austrians when they are talking German and (b) to read and fill out forms in German ( $1=$ very bad/not at all, 2 = quite bad, $3=$ moderate, $4=$ good, 5 = very good) (Cronbachs Alpha was again sufficiently high: 0.9 ). ${ }^{6}$

- Agreement on traditional gender roles: we used the item "It is the duty of the man to earn money, it is the duty of the woman to look after the household and the children" ( 1 = agree, 2 = partly, 3 = disagree).

- Identificative integration, understood as emotional orientation towards a group (cf. Esser 2009), is operationalised by two variables. First, by the variable sense of national belonging ( 1 = as Turk, Kurd, Croat..., 2 = rather as Turk, Kurd, Croat..., 3 = both as Austrian and as Turk, Kurd, Croat..., $4=$ rather as Austrian, $5=$ as Austrian) and, second, by the question interest in events in Austria ( $1=$ never, $2=$ rarer, $3=$ a couple of times a year, $4=$ a couple of times a month, 5 = several times a week, $6=$ daily), measuring the frequency of informing oneself.

4 It should be said that this variable only includes such persons who have previously been employed in Austria.

5 The respondents' social contacts include relatives, friends or acquaintances outside of the respondents' households in the previous two weeks.

${ }^{6}$ It should be mentioned that this variable includes only those persons whose first language is not German. 
Table 12.1. Descriptive statistics for the variables of the regression analyses

\begin{tabular}{ccccccc}
\hline & & Total & YUG- & YUG- & TUR- & TURN- \\
& & $(n=578)$ & $\begin{array}{c}\text { CIT } \\
(n=174)\end{array}$ & $\begin{array}{c}\text { N-CIT } \\
(n=110)\end{array}$ & $\begin{array}{c}\text { CIT } \\
(n=168)\end{array}$ & $\begin{array}{c}\text { CIT } \\
(n=126)\end{array}$ \\
\cline { 2 - 3 } & & \multicolumn{3}{c}{ \%/Mean (SD) } \\
\hline
\end{tabular}

\section{Independent variables}

\section{Citizenship}

Austrian $(\mathrm{n}=578)$

\begin{tabular}{lrrrrrrr} 
No & 0 & 1 & 40.8 & 0 & 100 & 0 & 100 \\
Yes & 0 & 1 & 59.2 & 100 & 0 & 100 & 0 \\
\hline $\begin{array}{l}\text { Migration experience } \\
\begin{array}{l}\text { Background (country of birth } \\
\text { of both parents) ( } \mathrm{n}=578)\end{array}\end{array}$ & & & & & & & \\
$\quad \begin{array}{l}\text { Turkey } \\
\text { Ex-Yugoslavia }\end{array}$ & 0 & 1 & 50.9 & 0 & 0 & 100 & 100 \\
\hline
\end{tabular}

\section{Migration generation}

(i.e. respondent is not born

$\left[1^{\text {st }} \mathrm{G}\right.$.] vs born in Austria

[2 $\left.\left.2^{\text {nd }} G.\right]\right)(n=578)$

\begin{tabular}{lrrrrrrr} 
1st generation & 0 & 1 & 76.5 & 74.7 & 87.3 & 66.1 & 83.3 \\
\multicolumn{1}{l}{ 2nd generation } & 0 & 1 & 23.5 & 25.3 & 12.7 & 33.9 & 16.7 \\
\hline $\begin{array}{l}\text { Length of stay in Austria } \\
\text { (i.e. age minus age at arrival in }\end{array}$ & & & & & & & \\
$\begin{array}{l}\text { Austria or age if born in Austria; } \\
\text { in years) ( } \mathrm{n}=577 \text { ) }\end{array}$ & 2 & 72 & 27.84 & 32.47 & 24.30 & 29.40 & 22.48 \\
\hline
\end{tabular}

\section{Socio-demographic charac-}

teristics

Gender $(\mathrm{n}=578)$

\begin{tabular}{lrrrrrrr} 
Female & 0 & 1 & 50.0 & 63.2 & 45.5 & 45.2 & 42.1 \\
Male & 0 & 1 & 50.0 & 36.8 & 54.5 & 54.8 & 57.9 \\
\hline Age (in years) ( $\mathrm{n}=578)$ & 16 & 91 & 42.58 & 46.59 & 44.89 & 39.55 & 39.04 \\
& & & $(14.60)$ & $(16.39)$ & $(14.93)$ & $(12.89)$ & $(12.03)$ \\
\hline
\end{tabular}

Educational level (i.e. highest

school-leaving qualification)

$(\mathrm{n}=578)$

\begin{tabular}{|c|c|c|c|c|c|c|c|}
\hline Compulsory school & 0 & 1 & 24.4 & 16.1 & 20.0 & 22.0 & 42.9 \\
\hline $\begin{array}{l}\text { Apprenticeship/ } \\
\text { vocational mid-level school }\end{array}$ & 0 & 1 & 40.7 & 46.6 & 47.3 & 35.7 & 33.3 \\
\hline $\begin{array}{l}\text { High-School certificate } \\
\text { (i.e. Matura, Abitur) }\end{array}$ & 0 & 1 & 23.0 & 23.0 & 19.1 & 29.2 & 18.3 \\
\hline University, FH & 0 & 1 & 11.9 & 14.4 & 13.6 & 13.1 & 5.6 \\
\hline
\end{tabular}




\begin{tabular}{ccccccc}
\hline & & Total & YUG- & YUG- & TUR- & TURN- \\
& & $(n=578)$ & $\begin{array}{c}\text { CIT } \\
(n=174)\end{array}$ & $\begin{array}{c}\text { N-CIT } \\
(n=110)\end{array}$ & $\begin{array}{c}\text { CIT } \\
(n=168)\end{array}$ & $\begin{array}{c}\text { CIT } \\
(n=126)\end{array}$ \\
\cline { 2 - 9 } & & & \multicolumn{3}{c}{$\% /$ Mean (SD) } \\
\hline
\end{tabular}

\section{Dependent variables}

Structural integration

Currently employed $(n=536)$

No

$\begin{array}{lllllll}0 & 1 & 31.0 & 31.0 & 33.3 & 27.2 & 34.3\end{array}$

Yes (dependently or

independently)

$\begin{array}{lllllll}0 & 1 & 69.0 & 69.0 & 66.7 & 72.8 & 65.7\end{array}$

Social integration

Share of Austrians in social

$\begin{array}{lllrrrrr}\text { contacts }(1=\text { none, } 5=\text { all }) & 1 & 5 & 2.48 & 3.01 & 2.50 & 2.34 & 1.91 \\ (\mathrm{n}=550) & & & (1.13) & (1.20) & (0.99) & (1.01) & (0.95)\end{array}$

Agreement on potential

interethnic marriages

(i.e. mean score of two

items) (1=in no way, 4=yes, $\begin{array}{lllllll}1 & 4 & 3.48 & 3.89 & 3.90 & 3.24 & 2.85\end{array}$

definitely) $(n=547)$

$\begin{array}{llll}(0.91) & (0.36) & (0.39) & (0.98)\end{array}$

Cultural integration

German language skills

(i.e. mean score of two

items; includes only

those persons whose first

language is not German)

( $1=$ very $\mathrm{bad} /$ not at all,

$\begin{array}{llll}4.29 & 4.77 & 4.30 & 4.33\end{array}$

3.62

$5=$ very good $)(n=529)$

$\begin{array}{llll}(0.92) & (0.46) & (0.87) & (0.84)\end{array}$

(1.05)

Agreement on traditional

gender roles $(1=$ agree,

13

$\begin{array}{lll}2.44 & 2.64 & 2.41\end{array}$

2.32

2.37

$3=$ disagree $)(n=574)$

$(0.75)$

(0.61) (0.78)

(0.79)

(0.78)

\section{Identificative integration}

Sense of national

belonging ( $1=$ as Turk, Kurd,

$\begin{array}{lllrrrrr}\text { Croat..., } 5=\text { as Austrian }) & 1 & 5 & 3.06 & 3.66 & 2.92 & 3.01 & 2.46 \\ (\mathrm{n}=557) & & & (1.13) & (1.05) & (1.10) & (1.06) & (0.95)\end{array}$

Interest in events in Austria

(i.e. frequency of informing

oneself $)$
$(1=$ never, $6=$ daily $)(n=573)$

$\begin{array}{lll}1 & 6 & 5.29\end{array}$

$5.57 \quad 5.53$

5.30

4.66

$(1.28)$

(0.91) (1.00) (1.16)

Source: SSÖ Migration Survey 2016; own calculations. 


\subsection{Independent variables: the role of citizenship and migration experience (explanatory variables) and socio-demographic characteristics (control variables)}

To prove the hypotheses, we use a number of independent variables that can be summarised under the headings of citizenship, migration experience and socio-demographic characteristics. Regarding citizenship, we differentiate between those immigrants who do not have and those who have Austrian citizenship ( $0=$ no, $1=$ yes). To comprehensively capture the effects of the migration experience on the integration outcomes, three variables are used: (a) the migration background - measured as the country of birth of both parents ( $0=$ Turkey, $1=$ ex-Yugoslavia) ${ }_{,}^{7}(\mathrm{~b})$ the migration generation (i.e. respondent was not born in Austria [first generation] vs was born in Austria [second generation]) $(0=$ first generation, 1 = second generation) and (c) length of stay in Austria (i.e. age in years minus age at arrival in Austria or age if born in Austria). In terms of socio-demographic characteristics, we include in our analysis respondents' gender ( $0=$ female, $1=$ male), age (in years) and educational level (i.e. highest school-leaving qualification) $(0=$ apprenticeship/vocational mid-level school, 1 = for various categories; see Table 12.1). In the regression analysis on explaining employment, we additionally include the interaction term migration background* ${ }^{*}$ ender.

\subsection{Methods of data analysis}

In our data analysis we use descriptive tables as well as multivariate analyses. For this latter we chose methods of multiple regression analysis. According to the scale level of the various dependent variables, we apply linear regression if it is quasi-metric, ordinal logistic regression in the case of one ordinal variable (agreement on traditional gender roles) and binary logistic regression in the case of one dichotomous variable (currently employed). Multiple regression analysis allows us to explicitly control for several other factors that simultaneously have effects on the dependent variable alongside the central "causal" factor. Therefore, it is more amenable to ceteris paribus analysis than bivariate regression (cf. Wooldridge 2013,68). We are aware, however, that we cannot establish a true causal relationship and conclude definitely from our findings whether naturalisation per se has an effect or not; a more successful integration of naturalised persons could also be the consequence of a selection effect, since well-integrated people may apply more frequently for citizenship.

7 This definition of a migration background excludes persons with mixed-origin parents (admittedly, those were non-existent in the survey) as well as persons with at least one parent born in Austria (21 persons in the survey) (Bodi-Fernandez et al. 2019, 319ff). We use this narrow definition of a migration background, since we want to have a clear comparison of groups with a Turkish and those with an ex-Yugoslavian migration background. 


\section{Empirical findings}

Firstly, we take a close look at the results of the multivariate regression analyses and discuss the contribution of the various independent variables in explaining the integration outcomes of the immigrants under study. Secondly, we provide additional descriptive findings on the integration differences that exist with regards to the migration background, citizenship status and length of stay in Austria among the studied groups.

\subsection{Findings of the multivariate regression analyses: the effects of citizenship, migration experience and socio-demographic characteristics on integration outcomes}

a. Naturalisation effect: in nearly all the integration outcomes under investigation (see Tables 12.2 and 12.3), naturalisation shows a significant positive effect. More precisely, immigrants holding Austrian citizenship show a higher probability of being currently employed (structural integration), of having a higher share of Austrians among their social contacts, more agreement on potential interethnic marriages (social integration), better German-language skills (cultural integration) and a more pronounced feeling of belonging to Austria (identificative integration) than those who do not have Austrian citizenship. These correlations are significant after controlling for many other variables that account for differences in migration experience and socio-demographic characteristics. However, in terms of gender-role attitudes and interest in events in the host society (further indicators of cultural as well as identificative integration) there is no significant correlation with citizenship status. In other words, better or worse integration outcomes in these matters seem to be independent of whether the immigrant is naturalised or not. Concerning gender-role attitudes, which are primarily framed by migration background, gender and educational level, this finding is plausible to some extent. However, with respect to a person's interest in events in Austria, it is surely surprising that his or her citizenship status should not be relevant. It might be expected that someone's interest in events in the host society would grow significantly when being a citizen of that country. Still, our findings regarding the naturalisation effect support, by and large, our first and most important hypothesis that naturalisation has a positive effect on integration outcomes in the host society in its four aspects of structural, social, cultural and identificative integration. Let us now discuss the role of the other variables used for explaining integration outcomes in the presence of the citizenship-status variable. Firstly, we take a look at the independent variables that are used to measure the respondents' migration experience.

b. Migration experience: we can see that those with an ex-Yugoslavian background are significantly better integrated in every respect than immigrants with a Turkish background. This is in line with our theoretical considerations and hence corroborates our hypothesis. The results regarding the differences in the integration outcomes be- 
tween the different migration generations can be summarised as follows: in contrast to being an immigrant from the first generation, belonging to the second generation significantly lowers the chances of being currently employed (structural integration) and lowers the share of Austrians among a person's social contacts (social integration) as well as his or her interest in events in Austria (identificative integration). In all the other integration indicators, no significant difference between the first and the second generation emerges.

The length of stay in Austria, a further variable used for operationalising the migration experience, is significantly positively related to the share of Austrians among a person's social contacts (social integration), German-language skills (cultural integration), sense of national belonging and interest in events in Austria (identificative integration). There are no significant relationships with the other three integration aspects (employment, attitudes towards gender roles and interethnic marriages). However, our hypothesis that integration increases with the duration of residence in the host society is mostly supported. Nevertheless, in terms of the generational differences in the integration outcomes, a somewhat opposite trend was observed, insofar as the second generation is less-well integrated than the first generation in some ways. It is important to add that, in the full regression models presented in this article, average integration differences between the first and the second generations are calculated after adjusting for their potential differences in the other characteristics included. Thus far, the average integration differences between immigrants of the first and the second generation are estimated ceteris paribus (i.e. all else being equal or, in other words, when they are of the same age and gender and when they exhibit the same length of stay in Austria etc.). Moreover, after controlling for the length of stay in Austria and age, it is questionable what effect remains of the migration-generation variable. Nevertheless, we decided to use all of these time-related variables (length of stay in Austria, migration generation and age) in our models in order to estimate their isolated effects on the integration outcomes. However, as they are isolated effects, they should also not be over-interpreted.

c. Socio-demographic characteristics: the various regression analyses show that respondents' socio-demographic characteristics are important as well in explaining integration outcomes. Male immigrants show significantly better integration results than female immigrants in most of the aspects of integration investigated here. For instance, male immigrants are more often in agreement with potential interethnic marriages (social integration) and are more interested in events in the Austrian host society (identificative integration) than their female counterparts. Only one exception to this pattern of significant gender differences in integration exists in the agreement on traditional gender roles (cultural integration); males do agree more strongly with these than females, who are the ones suffering from these traditional gender roles. On the contrary, no significant gender differences exist in German-language skills 
Table 12.2. Logistic regressions: effects of citizenship on being employed and on gender role attitudes

\begin{tabular}{|c|c|c|c|}
\hline & \multicolumn{2}{|c|}{ Binary logistic regression } & \multirow{2}{*}{$\begin{array}{c}\text { Ordinal logistic } \\
\text { regression } \\
\text { Agreement } \\
\text { on traditional } \\
\text { gender roles } \\
\text { (1=agree, } \\
3=\text { disagree }) \\
\end{array}$} \\
\hline & \multicolumn{2}{|c|}{$\begin{array}{l}\text { Currently employed } \\
\quad(0=\mathrm{No}, 1=\mathrm{Yes})\end{array}$} & \\
\hline & M I & $\begin{array}{c}\text { M II (incl. } \\
\text { interaction) }\end{array}$ & \\
\hline & $\operatorname{Exp}(B)$ & $\operatorname{Exp}(B)$ & Estimate \\
\hline \multicolumn{4}{|l|}{$\begin{array}{l}\text { Citizenship } \\
\text { Austrian citizenship (Ref. No) }\end{array}$} \\
\hline \multicolumn{4}{|l|}{$\begin{array}{l}\text { Migration experience } \\
\text { Migration background (Ref. Turkey) }\end{array}$} \\
\hline $\begin{array}{l}\text { Ex-Yugoslavia } \\
\text { Migration generation (Ref. } 1^{\text {st }} \text { gen) }\end{array}$ & $1.562^{+}$ & $2.272^{* *}$ & $0.644^{* * *}$ \\
\hline $2^{\text {nd }}$ generation & $0.287^{* *}$ & $0.309^{* *}$ & 0.018 \\
\hline Length of stay in Austria (in years) & 1.018 & 1.015 & 0.001 \\
\hline $\begin{array}{l}\text { Socio-demographic characteristics } \\
\text { Gender (Ref. female) }\end{array}$ & \multicolumn{2}{|c|}{ Socio-demographic characteristics } & \\
\hline Male & $1.860^{* *}$ & $2.701^{* *}$ & $-0.591^{* *}$ \\
\hline Age (in years) & $0.916^{* * *}$ & $0.916^{* * *}$ & $-0.025^{*}$ \\
\hline $\begin{array}{l}\text { Educational level (Ref. apprenticeship/ } \\
\text { vocational mid-level school) }\end{array}$ & & & \\
\hline Compulsory school & 0.738 & 0.723 & -0.199 \\
\hline High-school certificate (Matura, Abitur) & 0.784 & 0.755 & $0.405^{+}$ \\
\hline University, FH & 1.584 & 1.484 & $0.796^{*}$ \\
\hline Migration background*Sex & - & $0.460^{+}$ & - \\
\hline Constant & $45.424^{* * *}$ & $39.652^{* * *}$ & \\
\hline $\mathbf{N}$ & 535 & 535 & 573 \\
\hline $\begin{array}{l}\text { Nagelkerkes } \mathbf{R}^{\mathbf{2}} \text { (binary regression) } \\
\text { Pseudo } \mathbf{R}^{\mathbf{2}} \text { (Nagelkerke) (ordinal regression) }\end{array}$ & 0.223 & 0.231 & 0.111 \\
\hline
\end{tabular}

Source: SSÖ Migration Survey 2016; own calculations.

Notes: Significance levels: ${ }^{+} p<0.1,{ }^{*} p<0.05,{ }^{* *} p<0.01,{ }^{* * *} p<0.001$.

(cultural integration) and the sense of national belonging (identificative integration). With regards to differences between the gender groups in the likelihood of being currently employed (structural integration), we additionally calculated an interaction term between migration background and gender. The significant interaction 
Table 12.3. Linear regressions: the effects of citizenship on social contacts with Austrians, attitudes toward interethnic marriages, German-language skills, the sense of national belonging and interest in events in Austria

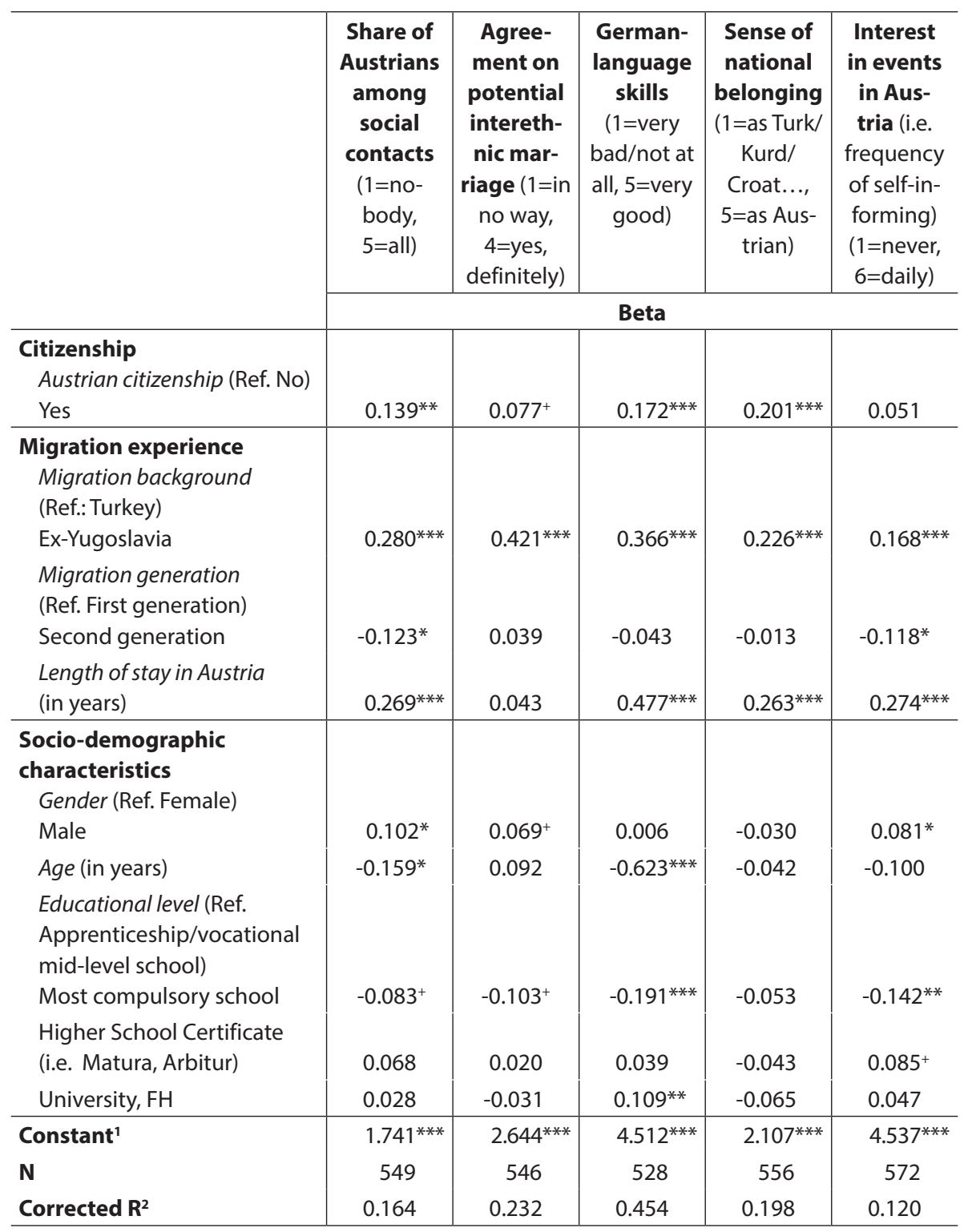

Source: SSÖ Migration Survey 2016; own calculations.

Notes: Significance levels: ${ }^{+} p<0.1,{ }^{*} p<0.05,{ }^{* *} p<0.01,{ }^{* * *} p<0.001 .{ }^{1}$ For the constant the unstandardised regression coefficients $B$ are shown. 
Table 12.4. Average integration differences according to immigrants' migration background, citizenship status and length of stay in Austria (means)

\begin{tabular}{|c|c|c|c|c|c|c|c|}
\hline & 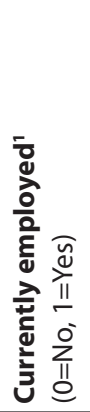 & 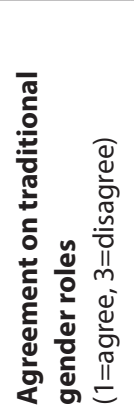 & 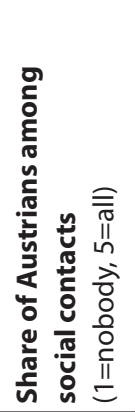 & 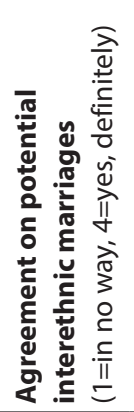 & 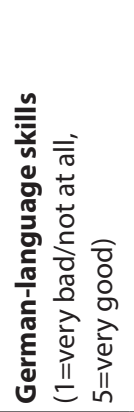 & 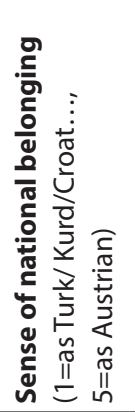 & 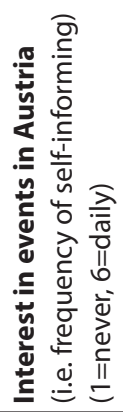 \\
\hline $\begin{array}{l}\text { YUG-CIT } \\
(<=25 \text { years) } \\
(n=81)\end{array}$ & $0.82^{*}$ & 2.70 & 2.81 & 3.86 & 4.79 & $3.34^{* *}$ & $5.41^{* *}$ \\
\hline $\begin{array}{l}\text { YUG-CIT } \\
\text { (> } 25 \text { years) } \\
\text { ( } n=92) \\
\text { (ref.) }\end{array}$ & 0.58 & 2.58 & 3.18 & 3.92 & 4.76 & 3.95 & 5.71 \\
\hline $\begin{array}{l}\text { YUG-N-CIT } \\
(<=\mathbf{2 5} \text { years) } \\
(n=65)\end{array}$ & 0.74 & 2.47 & $2.48^{* *}$ & 3.93 & $4.31^{*}$ & $2.80 * * * *$ & $5.45^{* * *}$ \\
\hline $\begin{array}{l}\text { YUG-N-CIT } \\
\text { (> } 25 \text { years) } \\
(n=45)\end{array}$ & 0.57 & 2.33 & $2.52^{*}$ & 3.85 & $4.27^{* *}$ & $3.07^{* * * *}$ & $5.65^{* *}$ \\
\hline $\begin{array}{l}\text { TUR-CIT } \\
(<=\mathbf{2 5} \text { years }) \\
(n=69)\end{array}$ & 0.63 & 2.45 & $2.43^{* *}$ & $3.16^{* * * *}$ & 4.49 & $2.86^{* * *}$ & $4.96^{* * * *}$ \\
\hline $\begin{array}{l}\text { TUR-CIT } \\
(>\mathbf{2 5} \text { years) } \\
(n=99)\end{array}$ & $0.79 *$ & $2.22^{*}$ & $2.27^{* * *}$ & $3.30^{* * * *}$ & $4.22^{* * * *}$ & $3.11^{* * *}$ & $5.55^{* * *}$ \\
\hline $\begin{array}{l}\text { TUR-N-CIT } \\
(<=25 \text { years) } \\
(n=87)\end{array}$ & 0.73 & 2.45 & $1.83^{* * * *}$ & $2.73^{* * * *}$ & $3.59 * * * *$ & $2.32^{* * * *}$ & $4.55^{* * *}$ \\
\hline $\begin{array}{l}\text { TUR-N-CIT } \\
(>25 \text { years }) \\
(n=39)\end{array}$ & 0.51 & 2.18 & $2.08^{* * *}$ & $3.10^{* *}$ & $3.68^{* * * *}$ & $2.74^{* * *}$ & $4.92^{* * * *}$ \\
\hline $\begin{array}{l}\text { Total }(\mathbf{n}) \\
(n=577)\end{array}$ & 535 & 573 & 549 & 546 & 528 & 556 & 572 \\
\hline
\end{tabular}

Source: SSÖ Migration Survey 2016; own calculations.

Notes: Significance levels: ${ }^{+} p<0.1,{ }^{*} p<0.05,{ }^{* *} p<0.01,{ }^{* * *} p<0.001$. Statistical differences of means to the reference group "YUG-CIT ( $>25$ years)" were tested by using Tukey-HSD (for the dependent variable "Sense of national belonging") and Games-Howell (for the other dependent variables). ${ }^{1}$ For the sake of consistency, means are also calculated for the dichotomous variable of being employed, which could also be presented in the form of percentages. 
term (see Table 12.2 MII) means that the difference between ex-Yugoslavian men's and women's probability of being currently employed is significantly lower than the difference between those of Turkish men and women; in other words, the difference between the gender groups varies according to the migration background, whereby Turkish women have fewer chances of employment than ex-Yugoslavian women in comparison to their male counterparts.

Our analysis also reveals some significant age differences in integration achievements, all of which were negative; this means that younger immigrants are - after controlling for a number of variables - on average better integrated than older ones. For instance, we see, not unexpectedly, that the agreement on traditional gender roles (cultural integration) is more pronounced among our elderly respondents. It is remarkable, however, that no significant age effect exists in any of the indicators for identificative integration as well as in the agreement on potential interethnic marriages (social integration). Finally, there are no significant differences, according to educational level, in the probability of being currently employed (supposedly because the question is whether one is employed or not, regardless of the quality of the job) and in regard to a person's sense of national belonging (which is more unexpected). However, the integration of immigrants is, in general, more advanced when they possess a higher educational level. For instance, higher-educated immigrants do have better German-language skills (cultural integration) and agree more on potential interethnic marriages (social integration) than immigrants with a lower educational level. Our results therefore support prior findings that immigrants' integration outcomes do correlate positively with educational level.

\subsection{Additional descriptive findings: average integration differences according to immigrants' migration background, citizenship status and length of stay in Austria}

Here we present some additional descriptive findings on the integration differences that exist concerning the migration background, citizenship status and length of stay in Austria of the immigrants in our study. In order to compare the average differences in integration between immigrants having and not having Austrian citizenship, we also include their length of stay in Austria (up to 25 years vs more than 25 years) to account for their duration of residence in Austria. ${ }^{8}$ This leads us to a typology of eight different groups that are compared in terms of their average integration outcomes (means) (see Table 12.4). For the comparison of the average integration outcomes between the different groups, those with a migration background from ex-Yugoslavia who have lived in Austria for more than 25 years were chosen as the reference group. According to the

8 The categories for the length of stay in Austria were chosen widely (up to 25 years vs more than 25 years) in order to have a sufficient number of cases in each of the comparison groups. 
regression analyses above, this group of immigrants is supposed to be the most integrated. Except for the average integration outcomes of being employed, this immigrant group indeed shows the best integration results in all respects, thereby confirming the multivariate findings.

\section{Concluding remarks}

Austria is a country with an exceptionally large number of immigrants in recent years. Official statistics as well as several studies have shown that the overall integration of immigrants is relatively good (Aschauer et al. 2019; Haller 2019; Statistik Austria 2018). At the same time, however, the legal situation makes it quite difficult for immigrants to attain Austrian citizenship (see Chapter 10 by Bauböck and Valchars in this volume). Our question was whether or not having host-country citizenship supports the integration of immigrants in Austria. Several but not all studies in different European countries have found such an effect. We used a survey of persons with a migration background who had immigrated to Austria from the former Yugoslavia and Turkey. By comparing those who are Austrian citizens with those who are not, we were able to test our central question. We looked at four different aspects of integration: structural integration (employment), social integration (social contacts with Austrians and agreement on interethnic marriages), cultural integration (knowledge of German and disagreement on traditional gender roles) and identificative integration (sense of national belonging and interest in events in Austria). Using multivariate analysis in order to control for other variables (such as age and migration generation), we found that naturalisation had a positive effect on integration in five out of seven indicators. No effect of naturalisation was found for gender-role attitudes (cultural integration) or interest in Austrian affairs (identificative integration). Thus, our central hypothesis has been affirmed by the empirical findings. This is in accordance with several other studies carried out in different European countries. Bratsberg et al. (2002) and Helgertz et al. (2014) found a positive effect of naturalisation on later income; Bevelander and Veenman (2006a) and Blatter et al. (2018) found positive effects on labour-market integration; a summary of additional studies is given in Prokic-Breuer, Dronkers and Vink (2013).

However, we should also point out some methodological limitations of our study that we have already mentioned above. A first concerns the problem of the representativity of the sample. It is obvious that, in the sample used, better-educated people were over-represented (Bodi-Fernandez et al. 2019). It is hard to say, however, what the findings might have been had we had a fully representative sample; there exists no obvious reason why they should be different. The second limitation is that the absolute numbers in the sample are quite low, which is often the case in surveys on or embracing immigrants. The third limitation is that our study is only a cross-sectional, one-time snapshot. Thus, we cannot establish a true causal relationship and conclude definitely, from our findings, whether 
naturalisation per se has a positive effect on integration. A more successful integration of naturalised persons could also be the consequence of a selection effect, since well-integrated people may apply more frequently for citizenship. Moreover, the relationship between citizenship and integration is probably reciprocal: naturalisation may enhance integration and integration may enhance a person's readiness to apply for naturalisation. The fourth limitation is closely linked to the fifth. Unfortunately, the survey did not ask whether a respondent had obtained Austrian citizenship by birth or by naturalisation. Since we also include immigrants of the second generation in our analysis, there may be a significant number in our sample who are Austrian citizens by birth (if either one of their parents obtained Austrian citizenship by naturalisation or is an Austrian citizen by birth) or who were naturalised upon application by their parents while they were minors. For these categories, the expected effects of citizenship should be different from those who naturalised as adults, as their life and integration process already started once they were awarded Austrian citizenship. Consequently, the self-selection of better-integrated immigrants into naturalisation should be a minor issue among these categories as this would be the only way for them to do so. Future research could address any differences between the various categories of immigrants.

Finally, we would like to highlight questions and possibilities for future research on this topic. First, additional theoretical considerations are necessary concerning the relationship between naturalisation and integration. Some authors have argued - also with supporting empirical evidence - that high hurdles to naturalisation support integration because they induce immigrants to make personal efforts - for instance, to improve their knowledge of the national language. Besides, a very fast and easy process of naturalisation could also dispose some immigrants to rely on welfare-state support (Heckmann 2015; Koopmans 2015; Prokic-Breuer et al. 2013). A study by Peters, Vink and Schmeets (2018) indicates that naturalisation has a positive impact on the economic integration of immigrants in the Netherlands even before naturalisation occurs, as

the employment probability of naturalising migrants already develops faster during the years leading up to citizenship acquisition, even when controlling for the endogeneity of naturalisation. We conclude that it is not just the positive signal of citizenship that improves employment opportunities, but also migrants' human capital investment in anticipation of naturalisation (Peters et al. 2018, 1051).

In a nutshell, whether high hurdles for naturalisation support integration or whether naturalisation fosters integration instead - or even both of these processes - can be beneficial in terms of the integration outcomes of immigrants and probably also depends to a great extent on their regional, social and cultural origin and their personal resources.

In terms of empirical research, two challenges should be addressed in future studies. One is to invent research designs which enable us to capture the real effect of naturalisation. Panel studies, looking at the same people over a number of years, would be one 
possibility. Another fruitful research design would be a comparative approach. Here we should look at countries with different rules for naturalisation but comparable groups of immigrants and investigate, in each of them, how the process of integration actually works.

\section{References}

Aschauer, W., Beham-Rabanser, M., Bodi-Fernandez, O., Haller, M. and Muckenhuber, J. (eds) 2019. Die Lebenssituation von Migrantinnen und Migranten in Österreich. Ergebnisse einer Umfrage unter Zugewanderten. Wiesbaden: Springer.

Bartram, D. 2019. The UK citizenship process: political integration or marginalization? Sociology, 53(4): 671-688.

Bevelander, P. and Veenman, J. 2006a. Naturalization and Socioeconomic Integration. The Case of the Netherlands. Bonn: Institute of Labor Economics, IZA Discussion Paper No. 2153. Available at: https://papers.ssrn.com/sol3/papers.cfm?abstract_id=908239 (accessed 03 December 2020).

Bevelander, P. and Veenman, J. 2006b. Naturalization and employment integration of Turkish and Moroccan immigrants in the Netherlands, Journal of International Migration and Integration, 7: 327-349.

Blatter, J., Sochin D'Elia, M. and Buess, M. 2018. Bürgerschaft und Demokratie in Zeiten transnationaler Migration. Hintergründe, Chancen und Risiken der Doppelbürgerschaft. Bern-Wabern: Eidgenössische Migrationskommission EKM, Research report. Available at: https://www.ekm.admin.ch/dam/data/ekm/dokumentation/materialien/ ekm-studie-doppelbuerger-d.pdf (accessed 04 December 2020).

Bodi-Fernandez, O., Hadler, M. and Mayer, C. 2019. Die Methodik der Zusatzerhebung unter Migrantinnen und Migranten im Rahmen des Sozialen Survey Österreich 2016, in Aschauer, W., Beham-Rabanser, M., Bodi-Fernandez, O., Haller, M. and Muckenhuber, J. (eds) Die Lebenssituation von Migrantinnen und Migranten in Österreich. Wiesbaden: Springer, 313-327.

Bratsberg, B., Ragan, J.F. Jr and Nasir, Z.M. 2002. The effect of naturalization on wage growth: a panel study of young male immigrants, Journal of Labor Economics, 20(3): 568-597.

Castles, S., Korac, M., Vasta, E. and Vertovec, S. 2002. Integration: Mapping the Field. London: Home Office, Online Report 28/03.

Çınar, D., Hofinger, C. and Waldrauch, H. 1995. Integrationsindex. Zur rechtlichen Integration von Ausländern in ausgewählten europäischen Ländern. Vienna: Institut für Höhere Studien.

Engdahl, M. 2011. The impact of naturalization on labour market outcomes in Sweden, in OECD (ed.) Naturalization. A Passport for the Better Integration of Immigrants? Paris: OECD, 99-130. 
Esser, H. 2009. Pluralisierung oder Assimilation? Effekte der multiplen Inklusion auf die Integration von Migranten, Zeitschrift für Soziologie, 38(5): 358-378.

Fassmann, H. and Münz, R. 1995. Einwanderungsland Österreich. Vienna: Jugend \& Volk.

Frank, K.A. 2000. Impact of a confounding variable on a regression coefficient, Sociological Methods and Research, 29(2): 147-194.

Hainmüller, J., Hangartner, D. and Pietrantuono, G. 2017. Catalyst or crown? Does naturalization promote the long-term social integration of immigrants? American Political Science Review, 111(2): 256-276.

Haller, M. 2019. Migration und Integration - Fakten oder Mythen? Siebzehn Schlagwörter auf dem Prüfstand. Vienna: Verlag der Österreichischen Akademie der Wissenschaften.

Heckmann, F. 2015. Integration von Migranten. Einwanderung und neue Nationenbildung. Wiesbaden: Springer VS.

Helgertz, J., Bevelander, P. and Tegunimataka, A. 2014. Naturalization and earning: a Denmark-Sweden comparison, European Journal of Population, 20(3): 337-359.

Just, A. and Anderson, C.J. 2012. Immigrants, citizenship and political action in Europe, British Journal of Political Science, 42(3): 481-509.

Karasz, L. and Perchinig, B. 2013. Studie Staatsbürgerschaft. Konzepte, aktuelle Situation, Reformoptionen. Vienna: Kammer für Arbeiter und Angestellte.

Koopmans, R. 2015. Social Cohesion and Immigration in Europe and North America: Mechanisms, Conditions, and Causality. London and New York: Routledge.

MIPEX 2015. How Countries are Promoting the Integration of Immigrants: Migrant Integration Policy Index. Barcelona: CIDOB Barcelona Center for International Affairs (www. mipex.eu).

Müller-Kmet, B. and Bodi-Fernandez, O. 2019. Emotionale Integration, nationale oder duale Identitäten? in Aschauer, W., Beham-Rabanser, M., Bodi-Fernandez, O., Haller, M. and Muckenhuber, J. (eds) Die Lebenssituation von Migrantinnen und Migranten in Österreich. Ergebnisse einer Umfrage unter Zugewanderten. Wiesbaden: Springer, 241-269.

OECD 2011. Naturalization: A Passport for the Better Integration of Immigrants? Paris: OECD. Available at: https://www.oecd-ilibrary.org/social-issues-migration-health/naturalisation-a-passport-for-the-better-integration-of-immigrants_9789264099104-en (accessed 04 December 2020).

OECD 2015. Indicators of Immigrant Integration 2015. Brussels and Paris: EU/OECD. Available at: https://www.oecd-ilibrary.org/docserver/9789264234024-17-en.pdf?expires= $1584295170 \& i d=i d \& a c c n a m e=$ guest $\&$ checksum $=3940794 F 4 E 3 B B 97749 E F B A C-$ 14CFB274D (accessed 04 December 2020).

Peters, F. and Vink, M. 2016. Naturalization and the socio-economic integration of immigrants: a life-course perspective, in Freeman, G. and Mirilovic, N. (eds) Handbook on Migration and Social Policy. Cheltenham: Edward Elgar, 362-376. 
Peters, F., Vink, M. and Schmeets, H. 2018. Anticipating the citizenship premium: before and after effects of immigrant naturalisation on employment, Journal of Ethnic and Migration Studies, 44(7): 1051-1080. doi: https://doi.org/10.1080/136918 3X.2017.1367650.

Prokic-Breuer, T., Dronkers, J. and Vink, M. 2013. The Faster, the Better? Speed of Naturalization and Socio-Economic Integration of Immigrants in Europe. The Hague: Ministerie van Veiligheit \& Justitie.

Riegler, H. 2000. Zwischen Rechtserwerb und Identitätsbedrohung. Einbürgerung aus der Sicht der Migranten, in Pilgram, A. and Steinert, H. (eds) Sozialer Ausschluss- Begriffe, Praktiken und Gegenwehr. Baden-Baden: Nomos Verlag, 183-201.

Scott, K. 2008. Investment in human capital, The American Economic Review, 37(19): 379-397.

Shadow Report 2017. Racism and Discrimination in Employment in Europe 2013-2017. Brussels: European Network Against Racism, ENAR Shadow Report.

Stadlmair, J. 2018a. Demokratische Mitbestimmung von Fremden aus politikwissenschaftlicher Perspektive, in Landtag, S. and Weiser, K. (eds) Demokratische Zukunft der (Salzburger) Landesgesetzgebung. Vienna: Jan Sramek Verlag, 121-155.

Stadlmair, J. 2018b. Earning citizenship: economic criteria for naturalization in nine EU countries, Journal of Contemporary European Studies, 26(1): 42-63 (Open access: https://doi.org/10.1080/14782804.2018.1437025).

Statistik Austria 2018. Migration \& Integration. Zahlen. Daten. Indikatoren. Vienna: Statistik Austria/Bundesministerium für Europa, Integration und Äußeres.

Steinhardt, M.F. 2012. Does citizenship matter? The economic impact of naturalizations in Germany, Labour Economics, 19(6): 813-823.

Stern, J. and Valchars, G. 2013. Naturalisation Procedures for Immigrants. Florence: European University Institute, Robert Schumann Centre for Advanced Studies.

Valchars, G. 2018. Staatsbürgerschaft: Recht und Praxis in Österreich, in Mosler, R., Pfeil, W.J. and Schrattbauer, B. (eds) Migration, Arbeitsmarkt und Sozialpolitik. Vienna: Manz, 163-190.

Wooldridge, J.M. 2013. Introductory Econometrics. A Modern Approach. Boston, MA: Cengage Learning ( $5^{\text {th }}$ edition). 



\title{
Chapter 13
}

\section{The Views of Expatriate Austrians on Dual Citizenship: The Results of a Worldwide Survey}

\author{
Florian Gundl, Institute of Sociology, University of Graz
}

\begin{abstract}
This chapter presents and discusses the results of a worldwide survey on dual citizenship among Austrians living abroad. A total of 2,403 people took part. The questions mainly focused on the respondents' attitudes towards (dual) citizenship. Most respondents showed a great interest in the subject. However, there are significant differences regarding the host country, the duration of stay in the foreign country and the level of education. Persons living in a Western country, as well as those with higher education, tend to be more in favour of dual citizenship. The longer people stay in a country, the more important the topic becomes to them. However, after a certain time (more than 20 years), the importance decreases again. The respondents evaluate citizenship not only for its symbolic and emotional value but also for its strategic advantages.
\end{abstract}

\section{Introduction}

This chapter presents the results of a survey conducted in 2019 among Austrians living abroad. The study is part of a larger research project in which the attitudes towards dual citizenship in general and towards the acquisition of Austrian citizenship in particular are investigated for three groups: South Tyroleans, Austrians living abroad and foreigners in Austria. ${ }^{1}$ The starting point for this project was the attempt of the former ÖVP-FPÖ ${ }^{2}$ government to offer dual citizenship to the South Tyrolean (Italian-Austrian) population. After asking the inhabitants of South Tyrol for their opinion on this issue, the next step was to survey the attitudes towards dual citizenship of Austrians living abroad. The motivation for the survey was the inconsistent and contradictive attitude of the Austrian government, which was considering providing Austrian citizenship to German-speaking South Tyroleans (who are Italian citizens) - and thus allowing them to have dual citizenship - even if most of them have no close ties to Austria. At the same time, it has been made continuously more difficult for immigrants in Austria to attain

1 The results of the survey in South Tyrol are presented in this volume in Chapter 14 by Atz and Haller. The survey among foreigner residents in Austria will be carried out in early 2021.

2 The ÖVP is the conservative Austrian People's Party, the FPÖ the far-right Freedom Party of Austria. 
Austrian citizenship (see Chapter 10 by Bauböck and Valchars in this volume). A similar inconsistency has been noted with regards to the different attitudes and policies for immigrants and emigrants, even in those countries that generally do not tolerate dual citizenship for either group (Chapter 10 by Bauböck and Valchars in this volume; Vink, Schmeets and Mennes 2019).

Currently about 580,000 Austrians live abroad (see Table 13.1). The Auslandsösterreicher-Weltbund (Weltbund.at 2019) ${ }^{3}$ (AÖWB) represents their interests and provides services for them. It is the umbrella organisation of the associations for Austrian expatriates who live all over the world, of which currently about 10,000 persons are members. In cooperation with Rainer Bauböck and Max Haller, the AÖWB has conducted a survey among its members, the focus of which was the attitudes of Austrians living abroad towards citizenship in general and dual citizenship in particular. It was also relevant for the Auslandsösterreicher-Weltbund (AÖWB), as the interest group representing these persons, to find out how strongly its members wanted the association to support access to dual citizenship.

\section{State of research and hypotheses}

Some recent studies on dual citizenship are presented below. Since this chapter focuses on empirical research findings, we refer to other articles in this volume for the theoretical foundations concerning (dual) citizenship. Here, we only refer to the findings of four papers which were especially important for this chapter. Lena Karasz and Bernhard Perchinig wrote a paper on Austrian citizenship, its history, the underlying goals, the present policy and a comparison with other European countries (Karasz and Perchinig 2013). They show that, in international comparison, Austria has a rather strict policy on citizenship; this is particularly evident compared to Switzerland, which has a more liberal policy. Joachim Blatter and his colleagues conducted a comprehensive study which scrutinised the situation in Switzerland. The Swiss government is generous when it comes to dual citizenship. One in four Swiss people living either in Switzerland or abroad has dual or multiple citizenship; among those living in Switzerland, the figure is 13 per cent. The authors emphasise the advantages of dual citizenship for a society, especially the stronger integration of persons with dual citizenship in the economic, political and social system (Blatter, Sochin D'Elia and Buess 2018). Harpaz and Mateos (2019) deal with the topic of dual citizenship and in particular 'strategic citizenship' from a global perspective. They illustrate the historical development of citizenship and recognise a new trend in recent decades to facilitate access to it. There has been a growing acceptance of dual citizenship which has affected the meaning of citizenship. Especially in non-Western countries, more persons are acquiring a second citizenship in order to use it to their advantage. This trend

3 World Association for Austrians Living Abroad. 
is strongly linked to the developments of global mobility (Harpaz and Mateos 2019). Another author who argues in favour of dual citizenship is the American legal scholar Peter J. Spiro, a leading expert on this topic. In his book At Home in Two Countries he describes the history of dual citizenship, which changed from strong disapproval in former times to widespread acceptance today (Spiro 2016; see also his Chapter 4 in this volume). The academic literature often distinguishes between an instrumental and an intrinsic value of citizenship and corresponding strategic and emotional interests (Bauböck 2018). The survey, therefore, not only refers to the concept of strategic citizenship as a means to personal advantage but also covers the emotional aspects of (dual) citizenship, such as feeling "at home" in a country.

Four general hypotheses were derived from the literature:

1. Austrians living abroad will be greatly interested in dual citizenship because this would enable them to participate fully in the public and political life of their host country while, at the same time, retaining close links to Austria. They will, therefore, also regard citizenship in general as important.

2. Persons living in Western, democratic and highly developed societies will have a greater interest in receiving the citizenship of these countries (and, thus, dual citizenship) than those living in poorer countries of the global South or in less-democratic countries.

3. The interest in (dual) citizenship and naturalisation will be low among persons who have only been living for a short time in a foreign country and higher among persons who have spent longer periods there. This is because a longer stay is accompanied by a stronger desire for participation.

4. With higher education, the interest in dual citizenship increases because educated persons tend to have more interest in participation in general.

\section{Survey methodology and sample}

A standardised questionnaire was developed in which 27 questions or statements were included. Some of the questions were also asked in the survey in South Tyrol, so that we can compare the two sets of results. The survey was carried out using online software (SurveyMonkey). A link to the survey was sent out via the distribution lists and social media channels of the AÖWB and its associations in the various countries. The survey was online from 11 September 2019 to 16 October 2019. A total of 2,403 respondents took part, which was clearly above expectations and showed how important the issue of citizenship seems to be for the recipients of the survey invitation.

The sample is composed as follows: 98 per cent of the 2,403 respondents currently do have Austrian citizenship, with the majority (90 per cent) having only Austrian citizenship. The remaining 10 per cent have dual citizenship. Almost half of the respondents 
(48 per cent) have been living in the host country for more than 20 years. Conversely, just over half of the participants (56 per cent) spent between 20 and 29 years of their lives in Austria.

\section{Table 13.1. Distribution of all Austrians abroad and respondents by country or world region (in \%)}

\begin{tabular}{lrr}
\hline Country or region & $\begin{array}{r}\text { All Austrians abroad } \\
\text { 2019* }\end{array}$ & $\begin{array}{c}\text { Sample of the AÖWB } \\
\text { survey }\end{array}$ \\
\hline Germany & 47 & 22 \\
Switzerland, Liechtenstein & 12 & 10 \\
Northern and Western Europe & 5 & 14 \\
(BE, AL, DK, Fl, FR, IE, IS, LU, NL, NO, SE) & & \\
Southern and Eastern Europe (all other & 10 & 8 \\
European countries including Turkey) & & 12 \\
USA & 5 & 4 \\
Canada & 1 & 6 \\
Australia, New Zealand & 4 & 9 \\
All other countries & 10 & 100 \\
Total & 100 & $(2,390)$ \\
(N) & $(579,700)$ & \\
\hline
\end{tabular}

* Source (Statistik.at 2019) for all Austrians abroad: http://www.statistik.at/web_de/statistiken/ menschen_und_gesellschaft/bevoelkerung/internationale_uebersich/036450.html (accessed 06 December 2020).

Two important facts become apparent in Table 13.1. On the one hand, we can see that the AÖWB survey has a very good coverage of Europe as well as a good coverage worldwide. On the other hand, there are also deviations between the sample and the real geographic distribution of Austrians living abroad. The respondents are clearly under-represented in Germany - where by far the largest proportion lives - and in Switzerland and Southern and Eastern Europe; they are over-represented in Great Britain and the rest of Northern and Western Europe and North America. We can suppose that there are three reasons why respondents in Germany are under-represented. One is that the AÖWB members are mostly higher educated, including people in qualified technical, scientific and managerial jobs. A large proportion of Austrians living in Germany, however, belonged to the first period of labour migration in Western Europe (1970-1980), when mainly people in blue-collar and routine white-collar jobs migrated from Austria to Germany. The second reason is that, for Austrians, living in Germany requires much less effort for their integration given the fact that they are native German-speakers. Third, since both Austria and Germany belong to the European Union, for Austrians most of the important social and mobility rights are guaranteed. Thus, most Austrians in Germany now will be well integrated into German society and feel little need to acquire German citizenship. 
The consequence is that the AÖWB survey as such cannot claim to be representative of all Austrians living abroad. This is, however, no major problem because our analysis is mainly comparative. In cross-tabular analysis, we will look at the characteristics of expatriates in different countries and world regions and compare them. In multivariate statistical analysis, the absolute number of people in certain categories does not distort the supposed causal connections, given that the underlying raw numbers for the categories in the independent variables are large enough.

With regards to education, 59 per cent of those surveyed have a university degree, 28 per cent have attained a secondary school or acquired a technical qualification and 12 per cent have completed primary school or vocational training. Data on the educational level of all Austrians abroad are not available; however, it can be assumed that the study clearly over-represents persons with higher levels of education. The distortions of the sample distribution compared to the distribution of all Austrians living abroad could also explain the over-representation of such people. Among the under-represented people living in Germany are probably many workers and employees with lower qualifications while, in the over-represented, mainly Anglo-Saxon, countries more highly qualified workers (technicians and engineers, scientists, managers, etc.) are probably employed.

The gender ratio is balanced, with 51 per cent women and 49 per cent men. Most people (88 per cent) are over 35 years old; with 24 per cent of the sample, the most strongly represented age group are those aged 45 to 54 .

\section{Results}

The various attitudes of respondents towards citizenship and dual citizenship were analysed and examined for differences in gender, age, educational attainment, origin (from which federal province), country or region of residence, length of stay abroad and number of years spent in Austria. The results are presented below.

\subsection{Importance of the topic of citizenship}

One question in the survey addressed the individual importance of the topic of citizenship. For the absolute majority (90 per cent) of respondents, citizenship is very important (58 per cent) or quite important (32 per cent), as seen in Figure 13.1.

There are significant differences by age of the respondents, with citizenship being more important for those over 35 than for younger people. Accordingly, there are also significant differences in the duration of the stay abroad: persons living abroad for more than ten years are more concerned with citizenship than those with a shorter stay. Persons with higher education are less likely to think of citizenship as "very important" and, instead, more often assess the subject as merely "important". This is a somewhat unexpected outcome, since citizenship is an important prerequisite for participation in a country and since higher-educated people are usually more interested in participation. It may, 


\section{Figure 13.1. Importance of citizenship by age, duration of stay in host country and highest level of education (in \%)}

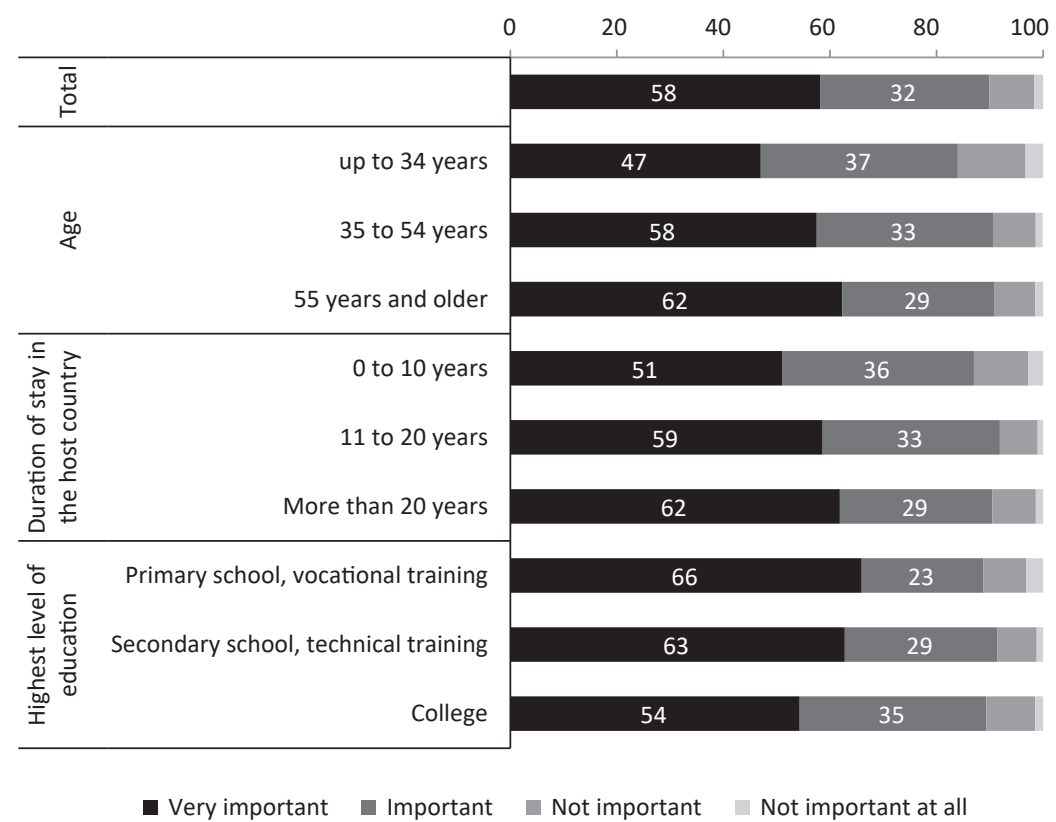

$\mathrm{n}=2,362$ (highest level of education) respectively 2,403 (duration of stay, age, and total). The number varies because there were fewer responses on the question about the highest level of education.

however, reflect a slightly stronger sense of participation through their professional status, independent of their citizenship.

Highly significant differences regarding the importance attached to citizenship emerge between the various countries of residence, as shown in Figure 13.2.

In global comparison, citizenship is considered as the most important by respondents living in Australia-Oceania and North America. In Europe there is a special situation: for people living in a non-member country of the EU, the topic of citizenship is much more important than for people living in an EU member country. The latter may be the case because EU citizens enjoy nearly the same rights as national citizens when living in another member state. Austrians living abroad in the UK are an exception from this rule. At the time when this survey was conducted, the UK was still part of the European Union although the Brexit process was already at an advanced stage and many foreign residents in the UK felt uncertain about their future situation.

Furthermore, there are no statistically relevant differences concerning the attitude towards citizenship in terms of gender, federal province of origin in Austria and number 
Figure 13.2. Importance of citizenship by region of residence, $n=2,390$ (in \%)

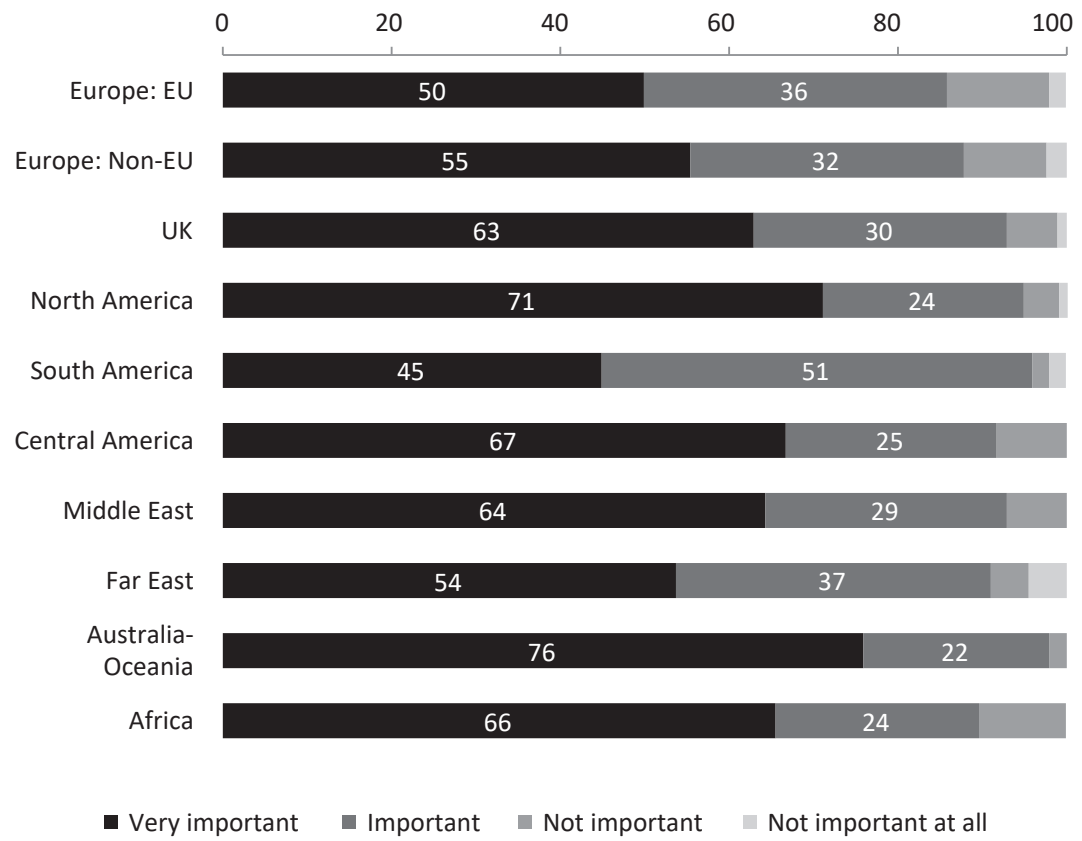

Table 13.2. Respondents' attitudes towards (dual) citizenship (in \%)

\begin{tabular}{|c|c|c|c|c|c|}
\hline Item & $\begin{array}{c}\text { Strongly } \\
\text { agree }\end{array}$ & Agree & Disagree & $\begin{array}{l}\text { Strongly } \\
\text { disagree }\end{array}$ & Total \\
\hline $\begin{array}{l}\text { One should not belong to two } \\
\text { states at the same time; } \\
\text { dual citizenships should in } \\
\text { principle be banned }\end{array}$ & 7 & 7 & 15 & 70 & 100 \\
\hline $\begin{array}{l}\text { Citizenship is not important; } \\
\text { the main thing is to be able to } \\
\text { work and live freely in a country }\end{array}$ & 12 & 24 & 32 & 33 & 100 \\
\hline $\begin{array}{l}\text { Austrians who have been living } \\
\text { abroad for some time should } \\
\text { be given easier access to dual } \\
\text { citizenship }\end{array}$ & 72 & 17 & 7 & 5 & 100 \\
\hline $\begin{array}{l}\text { Citizenship is an important sign } \\
\text { of belonging to a country }\end{array}$ & 60 & 30 & 8 & 2 & 100 \\
\hline
\end{tabular}

$\mathrm{N}=2,369$ to 2,381 . 
of years spent there. This is a remarkable fact, as one would suppose that these variables would have an influence. Surprising, also, is the non-existent difference between men and women. As will be seen in further results, gender does not seem to play an important role when it comes to interest in and attitudes towards citizenship in general.

\subsection{Basic attitudes towards (dual) citizenship}

The respondents were presented with a question containing four statements on which they could enter their agreement or disagreement on a four-level scale. The results are shown in Table 13.2.

We can see that the majority of respondents have a positive attitude towards (dual) citizenship - 90 per cent are convinced that citizenship is an important sign of belonging to a country. Two-thirds (65 per cent) think that citizenship is important even if you are allowed to work and live freely in a country. Moreover, 89 per cent of respondents think that access to dual citizenship should be made easier for Austrians who have been living abroad for some time, while 86 per cent reject a general ban on dual citizenship.

\section{Figure 13.3. Percentage of participants who responded "Strongly agree" to the statement "Austrians who have been living abroad for some time should be given easier access to dual citizenship" $(n=2,381)$}

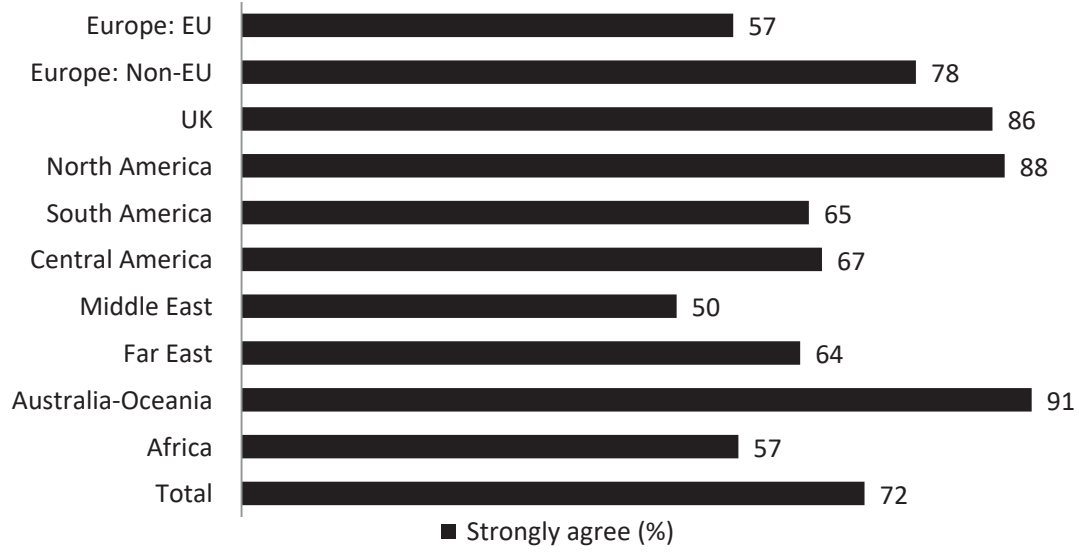

Clear differences can be seen depending on the region and duration of the stay abroad. The differences in region are illustrated in Figure 13.3, in the example of consent to easier access to dual citizenship for Austrians living abroad. The differences are quite remarkable. The most positive attitude towards (dual) citizenship can be found among Austrians living in Australia-Oceania and North America. At the other end of the scale but still with a positive attitude in principle - are those living in Africa, Central America 
and the Far East. Responses by interviewees in Europe, South America and the Middle East lie between these two poles. The situation is particularly interesting in Europe. Respondents in EU member states have little interest in demanding easier access to dual citizenship, whereas those living in a non-member state show significantly more interest. Respondents in the UK, which was, at the time of the survey, in the middle of the Brexit process, show even greater interest.

\section{Table 13.3. Logistic regression on determinants of the attitude towards dual citizenship}

\begin{tabular}{lll}
\hline Variable & & $\operatorname{Exp}(\mathrm{B})$ \\
\hline Gender (w/m) & & $0.752^{* *}$ \\
Age (3 categories: young to old) & $0.712^{* *}$ \\
Highest educational attainment (3 categories: low to high) & $1.283^{* *}$ \\
Duration of stay in host country (3 categories: short to long) & 1.102 \\
Years spent in Austria (3 categories: few to many) & & $1.265^{* *}$ \\
Region & Europe: EU (reference) & \\
& Europe: Non-EU & $2.930^{* *}$ \\
& UK & $3.625^{* *}$ \\
& North America & $4.653^{* *}$ \\
& South America & $2.073^{*}$ \\
& Central America & 0.758 \\
& Middle East & 0.876 \\
& Far East & $1.724^{*}$ \\
& Australia-Oceania & $6.135^{* *}$ \\
\hline
\end{tabular}

$\mathrm{N}=2,343$; Nagelkerke $\mathrm{R}^{2}=0.173$

Dependant variable: attitude towards dual citizenship ( 0 negative/indifferent; 1 strongly positive)

With regards to the duration of the stay abroad, a U-shaped connection can be observed: persons living abroad for between 11 and 20 years are more positive about (dual) citizenship than those staying abroad for shorter or longer periods. The age of respondents also plays a role - younger people tend to have a more positive attitude towards (dual) citizenship than older people.

Interestingly, in terms of gender there are no differences in the attitude towards citizenship in general though there are in the attitude towards dual citizenship - women are significantly more in favour of it than men. This is one of the rare occasions where gender does have implications on the respondent's attitude. The same phenomenon can be found in the review of educational qualifications: university graduates, in particular, are more positive about dual citizenship than people with formally lower educational qualifications. Again, there are no differences in attitudes towards citizenship in general. 
As the main focus of this article lies on dual citizenship, the two questions concerning this subject have been examined in detail. A new variable was created with two groups. One group consists of all people who strongly supported the claim of easier access to dual citizenship for Austrians who have been living abroad for some time and strongly disagree with the statement that dual citizenship should be generally banned. All other respondents are assigned to the second group. Afterwards a logistic regression model was created to examine which background factors are relevant for being in the group classification. The results can be seen in Table 13.3, which shows the influence of different variables on attitudes towards dual citizenship.

The model as a whole is significant although the strength of explanation is not very high, as reflected in the low Nagelkerke $\mathrm{R}^{2}$ value. Except for the duration of stay in the host country, ${ }^{4}$ all variables show significant influence. Women are more likely to be in favour of dual citizenship than men. With the increasing age of the respondents, the importance of the topic decreases. The higher the level of education, the more likely it is that the respondents have a positive view on dual citizenship. The attitude towards dual citizenship is significantly different for respondents in different regions. Compared to respondents living in EU member countries, where the interest in dual citizenship is quite low, respondents in Australia-Oceania, North America and the UK, in particular, have a high interest.

People who have been living in Austria for a longer period of time tend to be more positive towards dual citizenship than their counterparts with fewer years spent in the host country. This relationship seems to run opposite to the correlation with age. However, on closer examination the underlying variable may be the duration of stay in the host country, which did not show significant impact in this model. Figure 13.4 shows the share of respondents with a very positive attitude towards dual citizenship by duration of stay in the host country.

The U-shaped relationship between attitude towards dual citizenship and duration of stay in the host country, as mentioned above, can be seen in Figure 13.4. Respondents who have been living in the country of residence for a shorter or longer period of time show significantly less interest in dual citizenship compared to respondents with a medium duration of stay. One explanation may be that people who have been living in a country for only a few years are not yet considering applying for naturalisation. The longer they live in the host country, the more important this option becomes for them. After a long time living in the host country or at a certain age, they have come to accept their situation as a foreign resident and many may no longer bother about dual citizenship or naturalisation.

4 The variables age, duration of stay in the host country and years spent in Austria are correlated to a certain degree. This leads to a minor appearance of multicollinearity in the model. However, this does not affect the validity of the results. 


\section{Figure 13.4. Share of respondents with a very positive view on dual citizenship by duration of stay in the host country (in \%)}

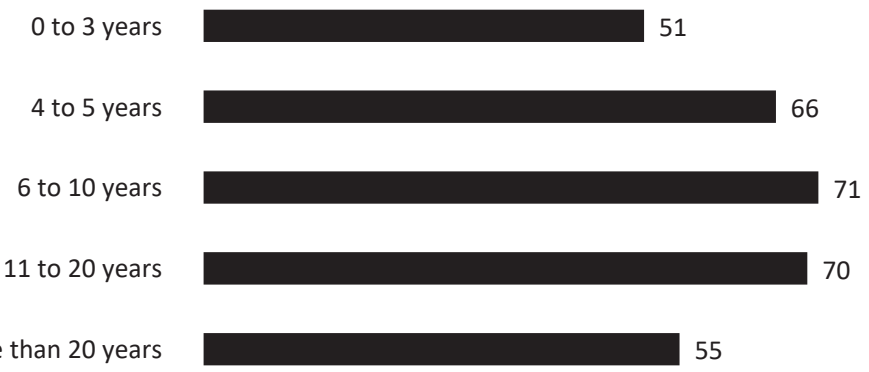

$\mathrm{N}=2,396$. Each bar can range on a scale from 0 to $100 \%$.

\subsection{Respondents' intentions regarding their own citizenship}

The participants in the survey were asked what concrete intentions they had with regards to their own citizenship. The question of whether they were fundamentally interested in acquiring the citizenship of their current country of residence was answered in the affirmative by two-thirds of respondents (65 per cent) but only on the condition that they could also retain their Austrian citizenship. Only 3 per cent of respondents would be willing to renounce their Austrian citizenship in order to obtain the new citizenship. Almost a quarter of the respondents ( 21 per cent) were not interested in acquiring the citizenship of their current country of residence.

Table 13.4 shows that there are differences between the respondents in several respects: the U-shaped relationship that had already emerged manifests itself again in the duration of the stay abroad. Persons who have lived in the host country for between 11 and 20 years tend to be more eager to acquire its citizenship, in contrast to persons with shorter or longer periods of residence. Of those who have lived in Austria for less than 20 years, a larger proportion is not interested in acquiring the citizenship of the host country than of those who have lived in Austria for more than 20 years. University graduates distinguish themselves from people with lower educational attainment by being more interested in acquiring the citizenship of the host country but, again, only on the condition that they can retain their Austrian citizenship. A gender comparison shows the same pattern: women are more willing than men to acquire the citizenship of the host country - if they can retain their Austrian citizenship in return. In contrast to the younger interviewees, those over 55 years of age were less willing to accept the citizenship of the host country. Again, large differences can be seen, depending on the country in which the respondents live. Almost two-thirds of our respondents in Africa and 
the Middle East had no interest at all in acquiring the citizenship of their host country. The interviewees in the Far East and in Central and South America had above-average little interest in acquiring the citizenship of their host country. In Europe, we can see a split: in EU member countries, the interest is not very high but in the other countries it is. It is also very high in North America and Australia-Oceania; more than 90 per cent of respondents there are interested in acquiring the citizenship of their host country.

Table 13.4. Willingness to accept the citizenship of the host country by duration of stay in the host country, highest level of education, sex, age and region of residence, $n=2,152-2,187(\%)$

\begin{tabular}{|c|c|c|c|c|c|c|}
\hline & & Yes* & $\begin{array}{c}\text { Yes, } \\
\text { but** }\end{array}$ & No & $\begin{array}{l}\text { Don't } \\
\text { know }\end{array}$ & Total \\
\hline Total & & 3 & 71 & 23 & 3 & 100 \\
\hline \multirow{3}{*}{$\begin{array}{l}\text { Duration of stay in the } \\
\text { host country }\end{array}$} & $0-10$ years & 4 & 71 & 21 & 4 & 100 \\
\hline & $11-20$ years & 2 & 80 & 16 & 2 & 100 \\
\hline & $20+$ years & 3 & 67 & 29 & 2 & 100 \\
\hline \multirow{3}{*}{ Highest level of education } & $\begin{array}{l}\text { Primary school, } \\
\text { vocational training }\end{array}$ & 4 & 65 & 30 & 2 & 100 \\
\hline & $\begin{array}{l}\text { Secondary school, } \\
\text { technical training }\end{array}$ & 3 & 65 & 30 & 2 & 100 \\
\hline & College & 3 & 75 & 19 & 3 & 100 \\
\hline \multirow{2}{*}{ Sex } & Female & 2 & 76 & 20 & 3 & 100 \\
\hline & Male & 4 & 66 & 27 & 2 & 100 \\
\hline \multirow{3}{*}{ Age } & $<34$ years & 4 & 76 & 15 & 5 & 100 \\
\hline & $35-54$ years & 3 & 77 & 18 & 2 & 100 \\
\hline & $55+$ years & 2 & 62 & 33 & 2 & 100 \\
\hline \multirow{10}{*}{ Region } & Europe: EU & 2 & 59 & 35 & 3 & 100 \\
\hline & Europe: Non-EU & 5 & 74 & 19 & 2 & 100 \\
\hline & UK & 1 & 87 & 9 & 3 & 100 \\
\hline & North America & 7 & 86 & 6 & 2 & 100 \\
\hline & South America & 0 & 59 & 37 & 5 & 100 \\
\hline & Central America & 0 & 67 & 25 & 8 & 100 \\
\hline & Middle East & 5 & 36 & 59 & 0 & 100 \\
\hline & Far East & 2 & 55 & 42 & 2 & 100 \\
\hline & Australia-Oceania & 1 & 91 & 8 & 1 & 100 \\
\hline & Africa & 0 & 31 & 62 & 8 & 100 \\
\hline
\end{tabular}

Note: * Yes, even if it means losing their Austrian citizenship; ${ }^{* *}$ Yes but only with the retention of their Austrian citizenship.

Furthermore, the respondents were asked to indicate possible reasons why they would like to acquire citizenship of their country of residence. The results are shown in Figure 13.5. Almost half of the respondents either stated that the country had become their 
second home or that they would like to take part in the elections ( 24 and 22 per cent respectively). In addition, the fact that citizenship is accompanied by more rights (12 per cent) and that security of residence is increased ( 12 per cent) also played a role for the interviewees.

\section{Figure 13.5. Reasons for acquiring the foreign citizenship (in \%)}

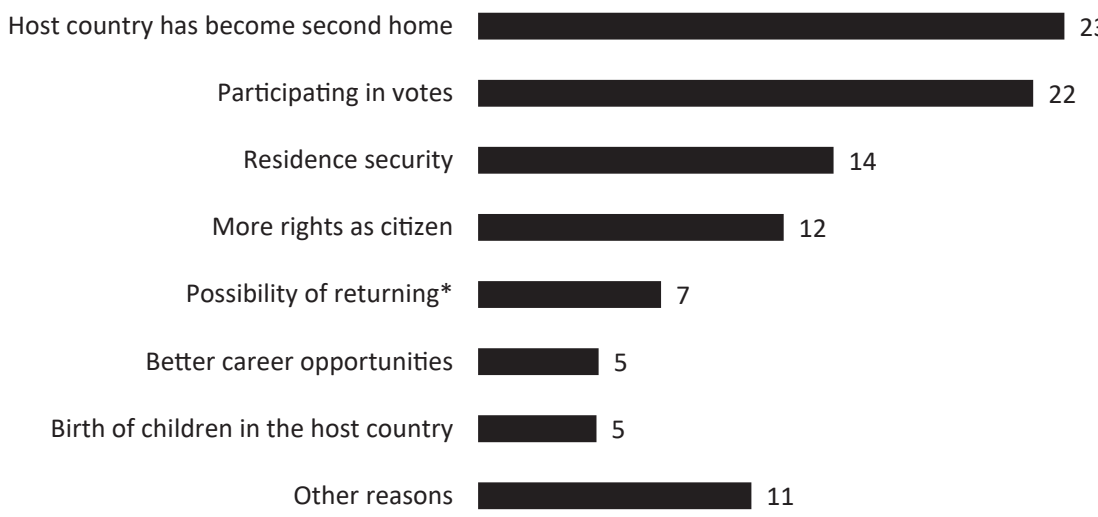

Notes: * The possibility of returning to the host country after leaving it; $n=2,403$; the individual reasons add up to 100 per cent.

There are interesting interrelationships between several factors: with longer stays in the host country, residence security, career opportunities and the gain in rights become less important for the interviewees. On the other hand, the aspects of feeling at home in the host country and the desire to vote become more important after a longer stay.

Clear differences can be seen between countries of residence. The need for residence security is above average in Central and North America as well as in the Far East. The interviewees in South America and Australia-Oceania hope for better career opportunities through citizenship while the possibility of electoral participation appeals particularly often to the interviewees in Europe. In North America and Australia-Oceania, citizenship providing the opportunity to return to the country of residence after leaving elicited an above-average response. With regards to educational qualifications, differences can be found, above all, because the country of residence has become the second home: this is less true for academics than for persons with a lower educational qualification. As far as gender is concerned, it is also worth noting that slightly more women than men cite participation in elections as a motive for obtaining citizenship. The same patterns as for the length of stay in the host country can be observed for age and the number of years spent in Austria. 


\subsection{Actions taken by respondents regarding (dual) citizenship}

The participants in the survey were asked several questions about the concrete steps they had already taken with regards to their citizenship status, with the questions mainly focused on the extent to which respondents had already made enquiries. The results can be found in Table 13.5 .

Table 13.5. Enquiries made by respondents about (dual) citizenship, $n=2,403$ (\%)

\begin{tabular}{lccc}
\hline Have you already enquired about ... & Yes & No & Total \\
\hline $\begin{array}{l}\text {... the acquisition of citizenship in your current country of } \\
\text { residence? }\end{array}$ & 60 & 40 & 100 \\
$\begin{array}{l}\text {... the acquisition of dual citizenship? } \\
\text {... the retention of your Austrian citizenship upon } \\
\quad \begin{array}{l}\text { acquisition of the citizenship of your country of } \\
\text { residence? }\end{array}\end{array}$ & 52 & 48 & 100 \\
\hline
\end{tabular}

Nearly two-thirds of respondents (60 per cent) said that they have already asked about the requirements for obtaining citizenship in their current country of residence. Those who have lived in the host country for 11 to 20 years have done so more often than the average. Those living in North America and Australia-Oceania, in particular, have often enquired about the conditions for being granted citizenship, while those living in the Middle East, Central America and Africa have asked particularly rarely. People with university degrees have more often made enquiries than those without. There are no gender differences. Fewer enquiries have been made by the over-50s compared to younger people.

Just over half of the respondents (52 per cent) have already enquired about the prerequisites for dual citizenship; the other half did not. With regards to the differences between the various groups of people, the same patterns emerge here as in answer to the question of whether or not respondents have already informed themselves about the requirements for citizenship acquisition in their current country of residence.

The even-more-specific question of whether respondents have already enquired of the authorities whether they can retain Austrian citizenship if they adopt a new nationality is answered positively by one third (31 per cent) of respondents. Here, too, the same patterns emerge as they did with the question of whether respondents had already informed themselves about the prerequisites for citizenship in their current country of residence.

\subsection{Meeting requirements for host-country and dual citizenship}

Two-thirds of respondents (67 per cent) stated that they meet the requirements for citizenship in their current country of residence, while 13 per cent of respondents answered "No" and 20 per cent do not know. Of those who had lived in the country of residence 
for more than 10 years, three-quarters knew that they meet the requirements. Among respondents with a shorter stay, the proportion is much lower, partly because more people do not know whether they meet the requirements. The percentage of respondents who do know is above the overall average only in North America and Australia. Here, the proportion of those who do not know whether they meet the requirements is also low. Education does not show any difference although those with a higher level of education are slightly better informed. Persons in the 35-54-year age group are better informed than the other age groups. There are no significant differences with regards to gender.

Another question shows that 83 per cent of respondents felt that the procedure for acquiring dual citizenship was complicated. Those who were better informed about it also agreed. In total 10 per cent of the respondents possess dual citizenship.

\section{Summary and interpretation}

Our analysis of the responses by the survey participants has shown that the first hypothesis (citizenship is an important issue for Austrians living abroad) can be confirmed. The majority of respondents cling to their Austrian citizenship and only a few are willing to give it up in favour of the citizenship of the country of residence. However, the willingness to acquire dual citizenship is high; the concept itself is also assessed positively by the majority of respondents. These results are consistent with the first hypothesis that there will be a high interest in dual citizenship because it enables Austrians living abroad to participate fully in the public and political life of their country of residence while, at the same time, retaining close links to Austria.

With regards to the factors that influence the opinions and attitudes of Austrians living abroad, the region in which the host country is located and the length of stay are particularly important. In the affluent western regions of North America and Australia, interest in acquiring citizenship is high while, in poorer regions such as Africa and Central and South America, it is low. This confirms the second hypothesis that the interest in acquiring citizenship is higher in the richer and fully democratic Western countries than in those of the global South. We can also see, however, that interest in acquiring citizenship in EU member states is lower. This is reasonable, given the fact that all social and mobility rights are secured for Austrians there. In Germany, in addition, the social and cultural integration of Austrians is easy. Interest in citizenship issues increases with length of stay, particularly among those who have been in the host country for 11-20 years. The interest is lower for people who have been living in the host country for a shorter duration as well as those who have been there for over 20 years. Thus, the third hypothesis is only partially confirmed. One explanation could be that, in their first years abroad, immigrants do not yet know whether they want to spend the rest of their lives in the host country. The more years they spend there, the more relevant the issue of citizenship becomes. After a long time in the host country, immigrants have already made 
their arrangements and the importance of the question of citizenship decreases again. Looking at the socio-demographic background of the interviewees, the comparatively high level of interest among younger people and those with a university degree has become particularly apparent. This confirms our fourth hypothesis. In contrast, gender rarely plays a role. Interestingly, which Austrian federal province the interviewee originated from made no difference at all.

Finally, it should be noted that, although a quite large sample size was achieved with 2,403 participants, the representativeness of this group is nevertheless problematic. The interviewees were self-selected members of the Auslandsösterreicher-Weltbund (AÖWB), an association for Austrians living abroad. Members of this association are probably significantly more educated than the whole group of approximately 570,000 Austrians living abroad. ${ }^{5}$ Most importantly, they probably have a higher interest in Austrian topics and thus also in Austrian citizenship than other Austrians living abroad. The sample is also not representative with regards to geographic distribution: the AÖWB has - in relation to the number of Austrians living in a certain country - more members in Anglo-Saxon countries where probably a large proportion of Austrians are working in highly skilled professional and managerial occupations, whereas the association is under-represented in Germany, where the proportion of low-skilled workers is probably higher. These caveats must be kept in mind when looking at the results, which can therefore be generalised to the remaining members of the AÖWB - however, a generalisation to all Austrians living abroad is not advisable. Nevertheless, the survey did deepen our knowledge on the topic of citizenship and dual citizenship and the results may encourage scientists to conduct follow-up studies.

\section{Acknowledgements}

We are very grateful to the AÖWB for carrying out a worldwide online survey among its members on this topic. We thank, in particular, the President of the AÖWB, Dr Jürgen Em, the President of the Austrian Club London, Jürgen Bischof (who carried out the survey) and Dr Irmgard Helperstorfer in the AÖWB office in Vienna for cooperating with us and providing us with the data for the analysis in this chapter.

\section{References}

Blatter, J., Sochin D'Elia, M. and Buess, M. 2018. Bürgerschaft und Demokratie in Zeiten Transnationaler Migration. Hintergründe, Chancen und Risiko der Doppelstaatsbürgerschaft. Bern-Wabern: Eidgenössische Migrationskommission EKM.

5 There are no statistics on the educational attainments of Austrians living abroad. Nevertheless, the proportion of respondents with a university degree is very high in this survey. 
Bauböck, R. 2018. Genuine links and useful passports: evaluating strategic uses of citizenship, Journal of Ethnic and Migration Studies, 45(6): 1015-1026.

Harpaz, Y. and Mateos, P. 2019 Strategic citizenship: negotiating membership in the age of dual nationality, Journal of Ethnic and Migration Studies, 45(6): 843-857.

Karasz, L. and Perchinig, B. 2013. Studie Staatsbürgerschaft. Konzepte, Aktuelle Situation, Reformoptionen. Vienna: Arbeiterkammer Wien.

Spiro, P.J. 2016. At Home in Two Countries: The Past and Future of Dual Citizenship. New York: New York University Press.

Statistik.at 2019. Auslandsösterreicherinnen und Auslandsösterreicher 2019. Available at: http://www.statistik.at/web_de/statistiken/menschen_und_gesellschaft/bevoelkerung/internationale_uebersich/036450.html (accessed 06 December 2020).

Vink, M., Schmeets, H. and Mennes, H. 2019. Double standards? Attitudes towards immigrant and emigrant dual citizenship in the Netherlands, Ethnic and Racial Studies, 42(16): 83-101.

Weltbund.at 2019. Informationen: Häufige Fragen. Available at: https://www.weltbund. at/information/haeufige-fragen-faq/ (accessed 06 December 2020). 



\title{
Chapter 14
}

\section{Does Dual Citizenship Endanger Ethnic Cohabitation? How the South Tyrolean Population Views a Supplementary Austrian Citizenship}

\author{
Hermann Atz, apollis - Institute of Social Research and Opinion Polling, \\ Bolzano-Bozen \\ Max Haller, Prof. Emeritus in Sociology at Karl-Franzens University, Graz and \\ Chair of the Vienna Association of Sociology
}

\begin{abstract}
A relatively new trend in research and public debates about dual citizenship is the collective granting of citizenship to nationally and ethnically related minority populations residing in neighbouring countries, as practised by Hungary or Italy (see the contributions in this volume by Pogonyi and by Pallaver and Denicolò - Chapters 7 and 9 respectively). A former Austrian federal government (2017-2019) proposed to offer Austrian citizenship to German- and Ladin-speaking South Tyroleans in addition to their Italian citizenship. The main argument for this proposal was to strengthen the historical and cultural relationship between the ethnic minorities of South Tyrol and their "fatherland" or "protecting nation", Austria. The topic of this study was the attitude of South Tyroleans towards this proposal. This attitude had not been investigated before, although several politicians and commentators had argued that South Tyroleans are very interested in it. This specific question was put into a larger theoretical and political context in two ways: on the one hand, the importance attached to citizenship by regional populations and, on the other, the political units with which the South Tyroleans identify today, especially their relationship with Austria. To this end, the social research institute apollis in Bolzano-Bozen interviewed a representative sample of South Tyroleans in spring 2019. The results show, surprisingly, that only a minority of them appreciate this Austrian proposal. One of the main reasons is the fear that dual citizenship would somewhat impair the coexistence of the language groups in South Tyrol. As far as ethnic-national identity is concerned, most of the respondents feel the closest to the region in which they live (South Tyrol) but very few identify with Austria, even among the German-speaking South Tyroleans. The most unexpected finding of the study is that the differences in perceptions and attitudes regarding the proposal are very slight between German- and Italian-speaking South Tyroleans. The validity of these findings is supported by the fact that similar results were obtained in surveys conducted among Hungarians living in Slovakia and among Romanians in Serbia and Ukraine.
\end{abstract}




\section{The problem of the collective conferral of dual citizenship}

Dual citizenship is an issue mainly relevant for individuals, usually migrants who reside in a new country without holding the citizenship of that country. However, it is also an issue touching upon collective groups. In recent times, for instance, Hungary has opened up the possibility for ethnic Hungarians living in Romania, Slovakia, the Serbian province of Vojvodina and Western Ukraine to be granted Hungarian citizenship (see Chapter 7 in this volume, by Szabolcs Pogonyi); Italy did the same for Slovenians and Croatians with Italian origins. The other comparable examples are mostly found in Central Eastern Europe - Poland, Romania, etc. (see Dumbrava 2014; Pogonyi 2017).

In 2017 the newly formed Austrian government included in its programme the proposal to grant Austrian citizenship to German- and Ladin-speaking South Tyroleans, in addition to their Italian citizenship, a proposal which was discussed widely in Austria, South Tyrol and Italy. The authors of this study decided, together with Günther Pallaver (University of Innsbruck) and Franceso Palermo (University of Verona and Eurac, Bolzano-Bozen), to carry out a survey among South Tyroleans from all three official language groups' to investigate their attitudes toward this proposal. In this chapter, we present the findings from this survey.

\subsection{Emergence of the problem in South Tyrol}

The idea to grant Austrian citizenship to German- and Ladin-speaking persons in South Tyrol in addition to their Italian citizenship appeared for the first time in 2006. Thirteen years later this proposition found its way into the programme of the Austrian federal government. To understand this apparently untimely initiative, one must look back into its historical origins.

The year 2019 marks the hundredth anniversary of the annexation of the southern part of the former crown land of Tyrol of the Austro-Hungarian Monarchy to Italy, as sealed in the Peace Treaty of St Germain. As a result, several hundred thousand people of German and Ladin mother tongue became Italian citizens at once. Most of the descendants of these ethnic groups now live in the Autonomous Province of Bolzano, South Tyrol, where they enjoy strong protection as linguistic minorities. The solution of the so-called South Tyrolean question by the Second Statute of Autonomy, which came into force in 1972, is today considered exemplary for the settlement of ethnic conflicts in multilingual areas (Haller 2006; Steininger 2003). In fact, Italian-, German- and Ladin-speaking citizens of South Tyrol have been living peacefully together since then, even though the

1 These three language groups are called "official" because their protection (schools in their language, equal representation in public service, police housing etc.) is guaranteed by the special autonomy statute for the Province of Bolzano, South Tyrol. This legal status does not pertain to speakers of other languages who immigrated to South Tyrol in recent times and now also constitute about 10 per cent of the population. 
language communities form quite clearly separated ethnic-linguistic sub-societies (Atz, Haller and Pallaver 2016). On the other hand, significant political forces, especially representatives of the South Tyrolean People's Party (Südtiroler Volkspartei or SVP), repeatedly emphasise that the German and Ladin language group is an "Austrian minority" whose "fatherland" is the present Republic of Austria. The proposal put forward in 2006 by two SVP parliamentarians in Rome (Siegfried Brugger and Karl Zeller) to grant German- and Ladin-speaking South Tyroleans Austrian citizenship in addition to Italian citizenship, if they so wish (Denicolò and Pallaver 2018), should be seen in this light.

The proposal fell on fertile ground both within and outside the SVP. It was adopted by the South Tyrolean Freedom Party (Süd-Tiroler Freiheit), whose mission is the separation of South Tyrol from Italy and its reintegration into Austria (Pallaver 2018). As a result, in March 2012 the South Tyrolean provincial parliament adopted a motion in favour of dual citizenship for ethnic minorities with the votes of the SVP and German opposition parties. A few weeks later, the SVP provincial assembly also adopted a resolution with the following wording: "As an expression of its close ties with the fatherland Austria in the European spirit, the South Tyrolean People's Party strives for dual citizenship for South Tyroleans" (SVP Club 2018, 4).

The Austrian federal government formed at the end of 2017 - consisting of an ÖVPFPÖ coalition which was in office until May 2019 - promised to grant Austrian citizenship to German- and Ladin-speaking South Tyroleans in its programme. ${ }^{2}$ Then in October 2019, the Austrian parliament in Vienna confirmed this intention. At the beginning of 2019, when this study was conceived, the prospect of dual citizenship for South Tyroleans belonging to the German or Ladin language group was thus quite concrete. Proponents as well as sceptics repeatedly made public statements on this issue. On the part of the supporters, arguments were put forward on very different levels, ranging from the idealistic goal of a stronger emotional connection to "Fatherland Austria", to the assertion that this would provide even better protection for the ethnic minorities and to personal benefits - for example, that Austrian citizenship would enable people to turn to the Austrian embassy abroad for support and use their mother tongue to explain their problems and needs. Critics argued above all that limiting access to Austrian citizenship to members of the German and Ladin language groups implied an exclusion of the Italian-speaking population, which would endanger inter-ethnic relations and social integration. Moreover, it would be superfluous - as both Italians and Austrian nationals are European Union citizens - and would contradict the European spirit.

Various legal experts also contributed to the debate. They stated that there are no clear agreements in international law on how so-called kin states can fulfil their role as a protecting power of linguistic, ethnic or religious minorities abroad who are close to

2 https://www.wienerzeitung.at/_em_daten/_wzo/2017/12/16/171216_1614_regierungsprogramm.pdf; accessed 6 June 2019). 
their own population. Rather, there is a more-or-less tolerated practice that ranges from a certain degree of recognition and financial support to the granting of citizenship (see Palermo 2020). For example, international law expert Peter Hilpold (2016) explained that such dual citizenship is possible under international law and compatible with the Austrian constitution. Walter Obwexer, expert in European and international law, argued that dual citizenship - despite being legally possible (Obwexer 2011) - could not only severely affect the intergovernmental relationship between Austria and Italy but could also weaken Austria's protective function, anchored at the international level. ${ }^{3}$ Former member of parliament Oskar Peterlini finally pleaded for extending the right to Austrian citizenship to all descendants of citizens of the Austro-Hungarian Monarchy in order to defuse the danger of ethnic tensions within South Tyrol (Peterlini 2019).

In any case, what the population itself thinks of the proposal and how it assesses the advantages and disadvantages expressed was the subject of pure speculation. Filling this gap by a representative population survey was thus the main intent of our survey, the results of which are presented here.

\subsection{Attitudes suggested by previous research}

As explained above, the focus of this chapter lies in the attitudes of South Tyroleans of all three language groups regarding the importance of citizenship in general and the additional granting of Austrian citizenship in particular. The empirical results reported here originate from a specific survey conducted for this purpose. ${ }^{4}$

Some indirect empirical evidence of these attitudes already exists in earlier studies. For example, a series of surveys asked which political community or territory the South Tyroleans primarily identify with. The findings were quite clear. According to the surveys conducted by the South Tyrolean Statistical Institute ASTAT under the label "South Tyrolean Language Barometer" in 2004 and 2014, between 80 and 85 per cent of the German-speaking population feel that they are "South Tyroleans", 3 to 9 per cent that they are Tyroleans, just under 10 per cent that they are Italians and a maximum of 2 per cent that they are Austrians (ASTAT 2006, 2015). ${ }^{5}$ Similar findings were revealed by surveys

3 Tageszeitung Dolomiten 12.11.2019.

4 The study is embedded in a larger project dealing with dual citizenship from various perspectives, which was conceived by Max Haller and Rainer Bauböck, together with other scholars (see the introduction by Bauböck and Haller in this volume).

5 In the two ASTAT surveys, the wording of the question is similar to that used in the apollis questionnaire but, in 2004, it provided for a reduced number of categories and only in 2014 were the categories "Austrian" and "I am not interested in the question of identity" added; in addition, multiple answers were possible. In the ASTAT 2014 survey, therefore, the question and possible answers were identical to those used by apollis. The difference is that, in the ASTAT survey, more than one answer was possible but these were not explicitly requested, whereas in the apollis questionnaire there were two separate questions (Atz and Forlin 2020, 200). 
conducted by the Institute of Social Research and Opinion Polling - apollis - in 2010 and the Austrian Opinion Research Institute Karmasin in 2013 (Denicolò and Pallaver 2018, 274). With regard to an eventual dual citizenship option for South Tyroleans, massive differences between German- and Ladin-speaking South Tyroleans versus Italian-speaking South Tyroleans are to be expected, since the offer of the Austrian federal government regarding the collective granting of citizenship was only directed at the first two groups. On the basis of the survey results mentioned above, however, even among these groups an unreserved support for the proposal cannot be expected, especially in view of its potentially divisive effect.

Regarding the attitudes of the South Tyrolean population towards the proposal to grant additional Austrian citizenship, we formulate the following five research questions; we also tentatively present some hypotheses.

1. What importance do South Tyroleans attach to citizenship for a person's life chances? Here we expect a comparatively high significance.

2. What do South Tyroleans mainly identify with - their country, South Tyrol (the province of Bolzano), the nation states of Italy or Austria or the European Union/Europe? It can be assumed that our study confirms the well-known finding that South Tyroleans identify primarily with their province and less with the Italian and Austrian states.

3. What do the people of South Tyrol know about the Austrian government's offer to grant Austrian citizenship to members of the German and Ladin language groups? How do they evaluate this offer? Since there has always been a lively, often emotionally charged public discussion on this topic, a relatively good level of knowledge can be expected.

4. Would the interviewees themselves apply for Austrian citizenship? What advantages would they see in this? What effects do they expect from such a policy? Due to the predominant national-territorial identification of South Tyroleans with their province, quite small percentages - only a minority - are to be expected here.

5. In all these questions, a differentiation must be made between the language groups due to the history of South Tyrol and the different ethnic and cultural affiliations. Can we expect strong differences between German- and Ladin-speaking persons on the one hand and Italian-speaking persons on the other?

\subsection{The survey}

The target of the survey are Italian citizens of all three language groups residing in South Tyrol aged 18 and over. A total of 700 persons were interviewed between 22 March and 08 April 2019 with a standardised questionnaire using CATI technology. ${ }^{6}$ The interviews

6 The research design and the questionnaire underlying this study were elaborated by Max Haller, Hermann Atz, Francesco Palermo and Günther Pallaver. Except for some general questions about 
were conducted in German or Italian, depending on the target person's main language. The sample was weighted according to demographic characteristics and is representative of the domestic population of South Tyrol, including the three official ethnic-linguistic groups (Südtiroler Landesregierung 2019). The sample includes 446 members of the German language group, 217 members of the Italian group and 33 of the Ladin language group (four respondents declared that they belonged to another language group). Due to the limited sample size, however, the problem arose that the total number of interviewed persons belonging to the Ladin language group was too small to make reliable statements. For some aspects of the analysis we nevertheless refer the results (to be interpreted with caution), for others we aggregate the Ladin and the German language groups because of their similar cultural traditions and their sharing of the condition of being an ethnic minority in Italy.

\section{Empirical results}

In this section the empirical results are presented. We begin with the opinions of South Tyroleans regarding the importance of citizenship and then present the findings on the identification of South Tyroleans with their province, with Italy and with Austria. In the third section, attitudes towards dual citizenship are recorded and the important question is examined as to whether there are significant differences in this respect between German- and Italian-speaking South Tyroleans. The last section deals in general with the question of which social groups attach great importance to citizenship per se.

\subsection{The importance of citizenship in general}

The possession of citizenship today must be seen as a decisive prerequisite not only for the political but also for the social and economic integration of a person into a territorially bounded society (see Chapter 2 by Max Haller in this volume). Most of the people growing up within one state and never emigrating to another are probably hardly aware of this. In South Tyrol this may well be different, because - as stated above - this country has only belonged to Italy for about a hundred years. Many South Tyroleans had negative experiences with (forced) emigration and the loss of citizenship in their own or their family histories. These included emigration to the German Reich on the basis of the option agreement between the two dictatorships in Rome and Berlin in 1939; ${ }^{7}$ the re-acquisi-

the importance of citizenship, which were used in all parts of the whole research project, all questions had to be developed specifically for this survey on the basis of a detailed knowledge of the policy proposal at that stage and the corresponding public debate at local level.

7 The option agreement forced German-speaking South Tyroleans to choose between full linguistic and cultural assimilation in fascist Italy or resettling in Eastern European territories conquered by the Nazi army. 
tion of Italian citizenship on the basis of the 1946 agreement between the Austrian and Italian foreign ministers, Karl Gruber and Alcide De Gasperi; and the massive emigration of the rural population from South Tyrol in the 1950s and 1960s while retaining Italian citizenship (Steininger 2003). The question of a possible return to the Austrian state was also on the political agenda for a long time and is still demanded by some secessionist parties. The first issue that arises, therefore, is the importance which the population of South Tyrol attaches to citizenship in general. Of course, the differences between the language groups are of particular interest.

The answers to this first question show a high level of awareness of this issue: almost two-thirds of respondents (61 per cent) consider citizenship to be very important in a person's life, a quarter (23 per cent) consider it to be quite important and only one person in six thinks that citizenship is unimportant. Interestingly, opinions on this are clearly dependent on the level of education but not in a way one might have expected: 67 per cent of people with primary school education consider citizenship very important whereas, among those with a university degree, this is true for only 49 per cent; the other educational groups are in between. ${ }^{8}$ There is also a clear correlation between age and support for the statement and a weaker one with gender: women agree more often than men and older people more often than younger ones. The fact that more highly educated people consider citizenship less important may well be related to the fact that their qualifications generally make it easier for them to find a job in another country than for less-educated people. The differences between the three language groups are slight: 81 per cent of German-speaking and even 92 per cent of Italian-speaking South Tyroleans consider citizenship to be important in a person's life, with Ladin-speaking South Tyroleans lying exactly in between. This is quite surprising and contradicts our expectations.

The respondents were asked to what extent they endorse four statements which dealt with this issue in general and with dual citizenship. The results are shown in Figure 14.1, where several interesting findings emerge. First, there is an apparent inconsistency: 62 per cent of respondents agree with Statement 2 ("Citizenship is not important"); however, the second part of the statement is: "The main thing is that you can work and live in a country without obstacles". This makes the high level of agreement plausible: citizenship is seen as very important precisely when social and economic rights are associated with it. One could therefore already conclude here that national citizenship is losing importance within the European Union because this latter, with its four fundamental freedoms, grants largely equal rights to all citizens of the Union in all member states.

8 A similar result emerged in an online survey among Austrians living abroad, where 66 per cent with only primary school education attributed high importance to citizenship compared to 54 per cent of those with a college degree. See Chapter 13 by Florian Gundl in this volume. 


\section{Figure 14.1. Attitudes towards different aspects of citizenship}

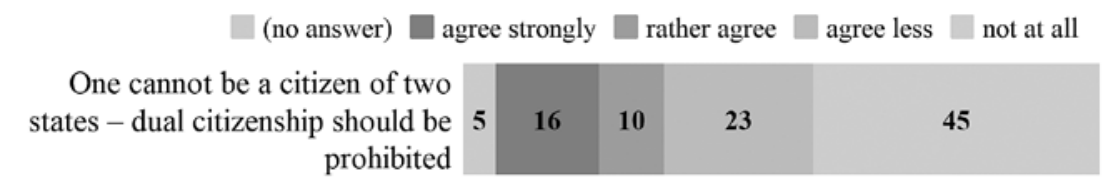
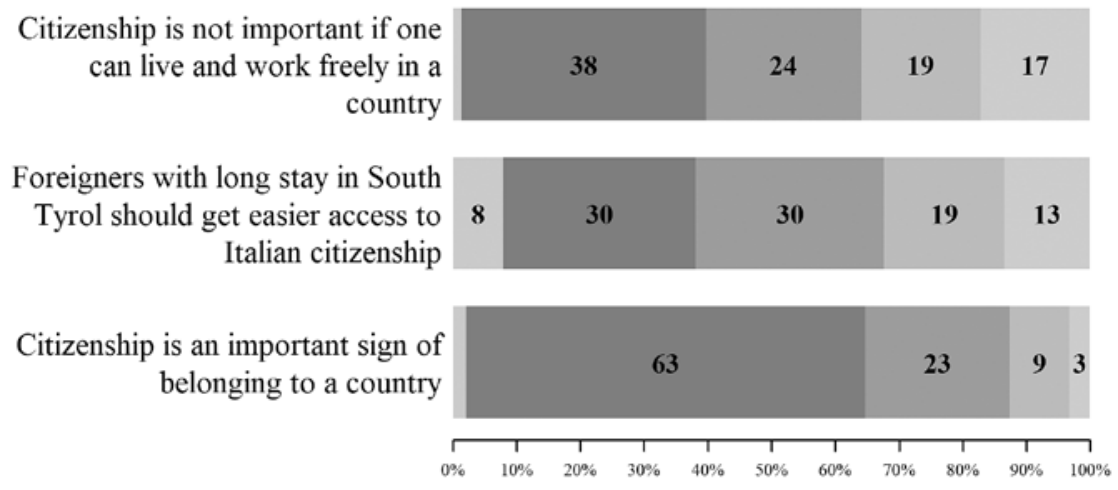

However, the further findings on this issue confirm the answers to the first question. For example, almost two-thirds of the respondents strongly agree that citizenship is an important sign of belonging to a country and a total of 86 per cent consider it (very or quite) important. There are also very tolerant and liberal attitudes towards the granting of citizenship: only 26 per cent agree with the statement that dual citizenship should be prohibited (68 per cent reject it) and a clear majority (60 per cent) thinks that foreigners who have been living in South Tyrol for a longer period of time should have easier access to Italian citizenship.

If we look at these attitudes according to social characteristics, one finding is clear: the rejection of dual citizenship decreases the higher the level of education - from about one third of those who only have compulsory schooling to 15 per cent of those with academic qualifications. This is probably mainly the case because these groups are actually or supposedly more often affected by competition from immigrants in the labour and housing markets. Older people may also see immigration as a threat to their familiar social environment. The age effect emerges clearly: only 14 per cent of respondents under the age of 35 are in favour of a ban on dual citizenship, compared with 37 per cent of those over 65 . There is little difference by educational group, however, when it comes to the statement that immigrants should be given easier access to Italian citizenship. There are also no remarkable differences between language groups.

We can therefore conclude that the majority of South Tyroleans consider citizenship as something very important for a person's life chances. They also express an open and inclusive attitude towards access to citizenship and the possibility of dual citizenship 
- a clear majority is in favour of allowing dual citizenship as well as facilitating the naturalisation of immigrants. For the younger generation, citizenship is less important and they are even more tolerant with respect to dual citizenship and naturalisation. It is very remarkable that there are only slight differences between the language groups. This makes it even more interesting to explore the attitudes of the different groups towards granting Austrian citizenship to German- and Ladin-speaking South Tyroleans.

\subsection{Ethnic-national affiliation}

The attitude which South Tyroleans have towards the question of an additional Austrian citizenship is certainly dependent upon their general ethno-national identification. Thus, it seems appropriate to first examine to which territorial-political unit or which identity (cultural) community South Tyroleans feel they belong and how relevant Austria is in this context. The distinction between language groups is particularly important in this regard.

Table 14.1. First and second ethnic-national affiliation by language group (sum of percentages)

\begin{tabular}{lrrrr}
\hline Foremost and second affiliation & Total & German & Italian & Ladin \\
\hline (Sample size) & $(700)$ & $(446)$ & $(217)$ & $(33)$ \\
South Tyrolean (German or Ladin) & 56 & 76 & 3 & $(61)$ \\
South Tyrolean (Italian) & 12 & 5 & 33 & $(0)$ \\
Altoatesino/a & 10 & 3 & 28 & $(17)$ \\
Ladin & 3 & 0 & 0 & $(58)$ \\
Italian & 35 & 28 & 59 & $(20)$ \\
Tyrolean & 8 & 11 & 1 & $(6)$ \\
Austrian & 2 & 3 & 0 & $(0)$ \\
German & 10 & 13 & 2 & $(6)$ \\
European & 32 & 32 & 35 & $(17)$ \\
World citizen & 14 & 11 & 23 & $(11)$ \\
Other & 3 & 4 & 1 & $(0)$ \\
No answer & 1 & 0 & 2 & $(0)$ \\
\hline
\end{tabular}

The wording of the question was: "In South Tyrol there is often talk of territorial or ethnic affiliation. What do you feel to be in the first and second place?" We can see here (Table 14.1) that by far the most important level of affiliation or identification is "South Tyrolean (German or Ladin)" with 56 per cent in total; in second place follows "Italian" at 35 per cent and in third place "European" at 32. Clearly lagging behind, with between 8 and 14 per cent, are "Altoatesina/o" (the Italian term for regional identity with regard to the 
Province of Bolzano "Alto Adige" ), "World citizen", "German" and "Tyrolean"; the category "Austrian" (2 per cent) is insignificant. It is noteworthy that practically no one states that he/she is not interested in the question; however, 14 per cent of the respondents limited their answers to a single classification.

Relevant are the differences between the German- and the Italian-speaking South Tyroleans. Among the former, "South Tyroleans" are in the lead with 76 per cent, followed by "Europeans" (32 per cent) and "Italians" (28 per cent); the category "Tyroleans" is mentioned by only 11 per cent and "Austrians" by only 3. The category "Germans" mentioned by 13 per cent probably means not the Federal Republic of Germany itself but, rather, membership in the German-language community. Among the South Tyroleans with Italian as their mother tongue, "Italians" are in the lead with 59 per cent; however, "Italian-speaking South Tyrolean" and "Altoatesino/a" together even make up a little more (61 per cent). This indicates clearly that their regional identification with the province of South Tyrol is also very strong. About one third of the Italian-speaking South Tyroleans see themselves as "Europeans". The findings for Ladin-speaking South Tyroleans are not representative; however, the available data indicate that they self-identify in a similar way to German-speaking South Tyroleans, apart from the fact that they very often identify primarily as "Ladins".

We can therefore state that affiliation with the province of South Tyrol is the most important (or at least equal to) type of identification for all three language groups. For members of the German- and Ladin-language groups it is clearly in the foreground, followed by the reference to Europe and to Italy. For members of the Italian-language group, belonging to Italy (or the Italian nation) is on a par with regional identification, followed by the connection to Europe. Austria plays practically no role as a country of identification, not even among the German-speaking population of South Tyrol.

For a further deepening of the topic it is useful to consider all the possible associations between the various levels of territorial-national identification. Only through the synthesis of the first and second affiliation can one analyse how strongly and in what way multiple identities - the so-called hyphenated identities (Atz and Forlin 2020) - are pronounced in relation to territorial and ethnic-national belonging in South Tyrol.

Looking at the various possible combinations of first and second identities according to aspects of ethnic uniqueness or ambiguity, the following results are obtained (see Table 14.2; for statistical reasons, we limit ourselves to the most common ethno-territorial classifications for the first):

- A good fifth of all people (22 per cent) can be classified as multi-ethnic German/ Ladino-Italian - i.e. they have a clearly hyphenated identity. However, most of them combine self-classification as South Tyrolean/South Tyrolean German- or Ladin-speaking with identification as Italian, which is perhaps more a commitment to the Italian state than to Italian ethnicity in the strict sense - but here the boundaries are fluid. 
Table 14.2. Frequencies of second ethnic-territorial affiliations conditioned by first affiliation, percentages per row (only for the most frequent categories)

\section{Second affiliation}

\begin{tabular}{|c|c|c|c|c|c|c|c|c|}
\hline First affiliation & 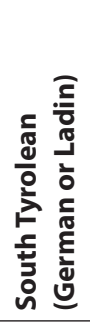 & 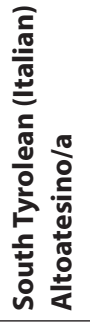 & 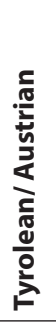 & $\begin{array}{l}\text { हू } \\
\text { हू } \\
\text { ऽ) }\end{array}$ & 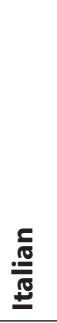 & 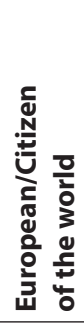 & 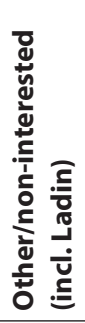 & 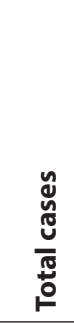 \\
\hline $\begin{array}{l}\text { South Tyrolean } \\
\text { (German or Ladin) }\end{array}$ & 0 & 6 & 13 & 8 & 27 & 29 & 17 & (316) \\
\hline $\begin{array}{l}\text { South Tyrolean (Ita } \\
\text { Altoatesino/a }\end{array}$ & 6 & 16 & 1 & 1 & 31 & 25 & 20 & (81) \\
\hline Italian & 11 & 28 & 1 & 5 & 0 & 39 & 16 & (105) \\
\hline $\begin{array}{l}\text { European/Citizen } \\
\text { of the world }\end{array}$ & 25 & 15 & 3 & 2 & 20 & 24 & 12 & (131) \\
\hline Total & 9 & 12 & 8 & 6 & 21 & 28 & 16 & (700) \\
\hline
\end{tabular}

A smaller part (about 4 per cent of the total population) identifies itself both as German-speaking or Ladin-speaking South Tyroleans and as Italian-speaking South Tyroleans (in South Tyrol this group is often called the bilinguals).

- More than a third associate an ethnic German (23 per cent) or Italian (14 per cent) identity with a transnational orientation as citizens of Europe or the world.

- People identifying themselves exclusively as Germans or Ladins make up just under a quarter of the sample (21 per cent), while those who categorise themselves only as Italians make up 13 per cent. Thus, these ethnically one-dimensional identities can be found in another third of the sample.

- The rest are people with a purely transnational orientation (6 per cent) or without any indication regarding their ethnic or national affiliation (1 per cent).

Thus, on the one hand, it is true that the territorial bond is in the foreground or at least plays a very important role for South Tyroleans of all linguistic groups. On the other hand, the analysis of the combinations shows that mono-ethnic affiliations - with or without a further transnational orientation - still constitute the "normal case". This resembles the national identities typical for migrants, many of whom identify with both their countries of origin and of destination (see Chapter 2 by Haller in this volume). A decidedly multi-ethnic identity, however, is present in more than a fifth of the (autochthonous) population of 
South Tyrol - not considering residents with foreign citizenship, who constitute a further 9 per cent of the total population (for more details see Atz and Forlin 2020).

\section{Figure 14.2. The various forms of relationship of South Tyroleans to Austria}

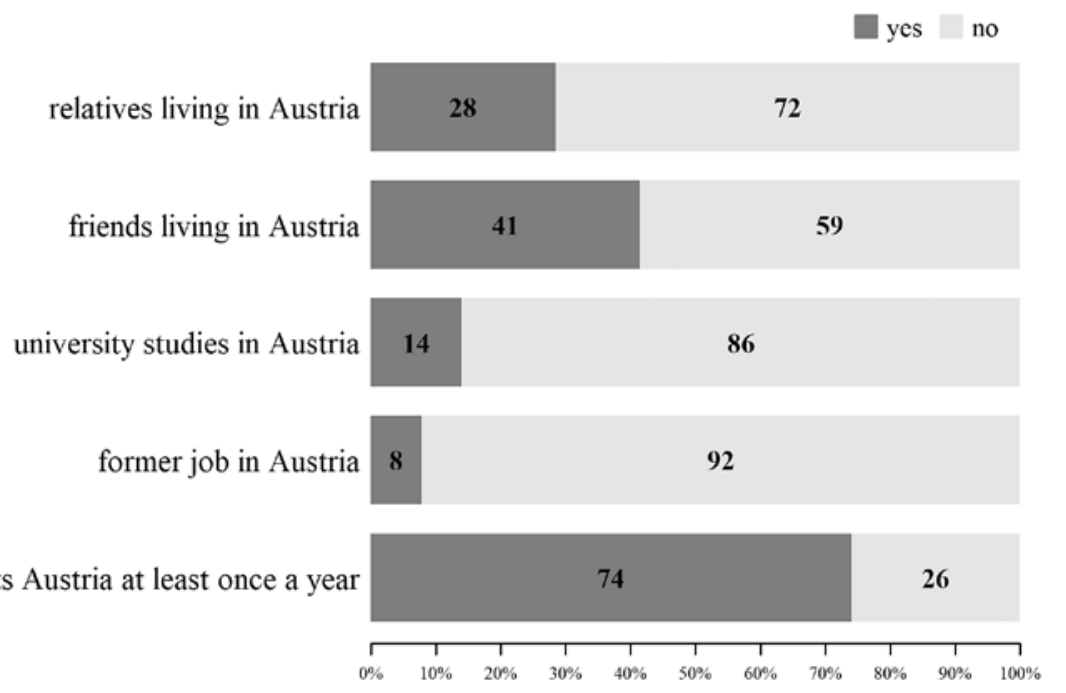

\subsection{Connections to Austria}

Two further questions were asked in order to capture the relationship of South Tyroleans to Austria in more detail. The first was whether respondents had a concrete biographical relationship with Austria (cf. Figure 14.2); the second was whether they are interested in Austrian politics and also watch Austrian news channels - in addition to Italian and other channels. More than a quarter of all those questioned have relatives -41 per cent even have acquaintances - in Austria. These values are significantly higher among German-speaking South Tyroleans than among Italian-speaking ones. It is less common to have studied or worked in Austria (14 and 8 per cent respectively). However, visiting Austria (at least once a year) happens much more frequently: three-quarters of all respondents do so; even about half of all Italian-speaking South Tyroleans visit Austria quite regularly. In this regard, the Italian-speaking South Tyroleans are similar to all Italians who, in recent times, constitute a significant group of tourists in Austria - particularly in Vienna - thus intensifying the positive relations between Austria and Italy which have developed over recent decades.

These percentages largely coincide with those of the Euregio Monitoring 2017, in which three-quarters (73 per cent) of South Tyroleans also stated that they had visited Tyrol at least once a year. The surveys showed that people with relatives in the neighbour- 
ing country have a significantly higher level of travel activity. A comparison between the German- and the Italian-language groups is significant: around 80 per cent of members of the German-language group stated that they had visited Tyrol last year, while the figure for the Italian-language group was 55 per cent in 2017 and 46 per cent in 2015 (Traweger and Pallaver 2018).

What about the interest in politics and the media in South Tyrol, Italy and Austria? About two-thirds of our interviewees state that they are very or quite interested in politics in South Tyrol, Italy and Europe; with regard to Austrian politics this share is only 24 per cent. There are also differences between the language groups but they are not very pronounced: Italian-speaking South Tyroleans are slightly more interested in South Tyrolean politics and significantly more in Italian politics; German-speaking South Tyroleans are slightly more interested in European politics. Politics in Austria interests 28 per cent of the German-speaking and 16 per cent the of Italian-speaking South Tyroleans. Their media preferences also reflect the strong focus on South Tyrol but there are significant differences by language group, as 70 per cent of German-speaking and 54 of Italian-speaking people regularly watch local South Tyrolean TV stations. The opposite is true for national Italian TV stations (regularly watched by only 17 per cent of German-speaking but 84 per cent of Italian-speaking South Tyroleans). Austrian, German and Swiss channels are watched regularly by about one third of the German-speaking South Tyroleans but by only 3 per cent of the Italian-speakers.

\subsection{Opinions on South Tyrol's special autonomy}

Finally, the assessment of the impact of South Tyrol's autonomy is also relevant to the issue of the extent to which South Tyroleans identify with their country. This evaluation is very positive overall: the majority of respondents are convinced that the special autonomy of South Tyrol has promoted economic development and ethnic cohabitation, ensures the protection of minorities and benefits all language groups equally (cf. Figure 14.3).

However, there are significant differences between the language groups: the German-speaking South Tyroleans have a much more positive attitude towards regional autonomy than the Italian-speaking ones: 89 per cent think that it protects minorities, 80 per cent that it promotes cohabitation and 73 per cent that it benefits all three language groups equally. The corresponding percentages in the Italian-language group are 75, 72 and 51 per cent. If we look only at the percentage of strong agreement ("very"), the differences become even greater. However, when asked directly how well the autonomy of South Tyrol is secured, more German- than Italian-speaking South Tyroleans (26 vs 11 per cent) answered that it is less-well secured or not secured at all. Overall, however, 70 per cent of those questioned are also convinced that South Tyrol's autonomy is well secured. Only regarding the benefits of autonomy for economic development did we find a very positive consensus in both language groups. The lesser satisfaction of Italian-speaking South Tyroleans with autonomy and with their political situation - while at the same 
time being highly satisfied with the economic situation - is a phenomenon that has been known for some time from other research (see, most recently, Atz, Haller and Pallaver 2016). In the longer term, it is probably related primarily to the political fragmentation of the Italian parties in South Tyrol, which has led to an under-representation of the Italian-speaking population in the political representative bodies. In objective terms (in terms of educational level, employment and income), however, no significant differences between the language groups can be identified today (ibid.).

\section{Figure 14.3. Opinions on a special autonomy for South Tyrol}
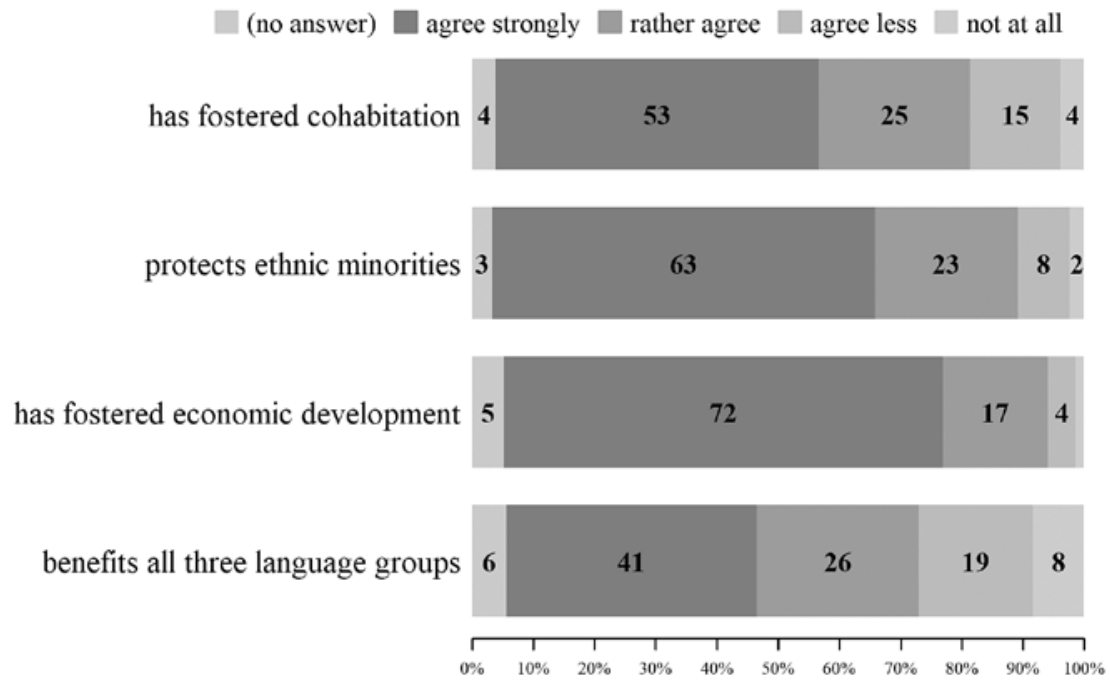

\subsection{Attitudes towards dual citizenship}

As an introduction to the issue of Austrian citizenship for South Tyroleans, respondents were asked whether they had heard of this idea. This was indeed the case for almost all respondents ( 97 per cent in the German- and 94 per cent in the Italian-language group). This is certainly an indicator that this question has high salience.

The results for the direct question on the assessment of dual citizenship show that only a quarter of respondents consider it a very good (5 per cent) or good idea (20 per cent); one third (32 per cent) think it is problematic and almost a third (31 per cent) think it should be completely rejected; one in eight did not express a clear opinion on the issue. Thus 63 per cent, almost two-thirds of the South Tyrolean population, have a generally negative attitude towards granting Austrian citizenship to German- and Ladin-speaking South Tyroleans. This can only be described as a massive verdict against the promoters of this idea in Austria and South Tyrol. The results of the last South Tyrolean provincial 
elections in October 2018 can also be interpreted as confirmation of this finding. In this election, the main supporters of this policy proposal in South Tyrol - the Süd-Tiroler Freiheit and the Freedomites (Die Freiheitlichen) - performed modestly or even very badly (the Freedomites experienced a strong decline from 17.9 to 6.2 per cent of the vote), while the representatives of the very successful Liste Köllensperger were more reserved about the idea of dual citizenship. On the other hand, the dominant party of the German-speaking population, the South Tyrolean People's Party or SVP, which had been actively promoting this idea some years ago, has been rather quiet recently.

Of great interest in this context are the attitudes of members of the two larger language groups in South Tyrol towards dual citizenship. As expected, a large majority (71 per cent) of the members of the Italian-language group are critical of the idea. In the German-language group, too, the critical voices clearly predominate with 62 per cent. If this attitude is broken down according to the social characteristics of the respondents, clear differences can only be seen by age group: younger people (aged 18-34) have a much more positive attitude towards this idea (40 per cent) than people of middle (ca. 30 per cent) and higher age (65+, 17 per cent). The difference between German- and Italian-speakers is quite limited (in support 28 vs 17 per cent).

A clear rejection of the collective granting of dual citizenship to South Tyroleans is also expressed when respondents were asked about its effects on ethnic cohabitation in South Tyrol. In total, only 10 per cent think that dual citizenship would promote the peaceful coexistence of ethnic groups; 40 per cent think that it would have a negative impact, 36 per cent see no impact and a further 15 per cent do not want to give an assessment. It is particularly noteworthy that there are also hardly any significant differences of views on this issue between language groups - even among German-speakers only a minority expect positive effects and the proportion of those who expect negative effects is almost the same in both language groups.

There is another indication in our study that South Tyroleans are aware of the possible negative effects of dual citizenship and see it as a serious problem. We asked the group of interviewees who would certainly or possibly apply for Austrian citizenship the following question: "Would you refuse the additional Austrian citizenship in the end, if it is foreseeable that this possibility endangers the peaceful coexistence of the language groups?" Of those questioned, 43 per cent answered "Yes, in any case", another 27 per cent "Yes, under certain circumstances" amd only 9 per cent would apply for it anyway (21 per cent did not answer the question). The German-speaking South Tyroleans answered "Yes, in any case" much less frequently (36 compared to 62 per cent of the Italian-speakers). However, if we add those who would decline "under certain circumstances", the difference disappears. Only 11 per cent of German-speaking and 7 per cent of Italian-speaking people would not give up on the Austrian citizenship option in any case.

An important question now is who would apply for Austrian citizenship if it became possible. According to the answers to our survey, this is only about one third of the 
respondents - only 12 per cent would do so "definitely" and another 22 per cent "under certain circumstances". Even among German-speakers only 13 per cent are sure to apply eventually. It is noteworthy that, in this respect, there are hardly any differences between the language groups; about a quarter of the Italian-speaking South Tyroleans would also possibly or certainly make such an application. However, there are clear differences according to the age and level of education of respondents: younger people and those with higher levels of education are more likely to apply. This may be mainly due to the fact that people with higher education tend to be more mobile and a high proportion (42 per cent) of them have studied in Austria, so they know the country and its politics quite well.

\section{Figure 14.4. Advantages of an additional Austrian citizenship}

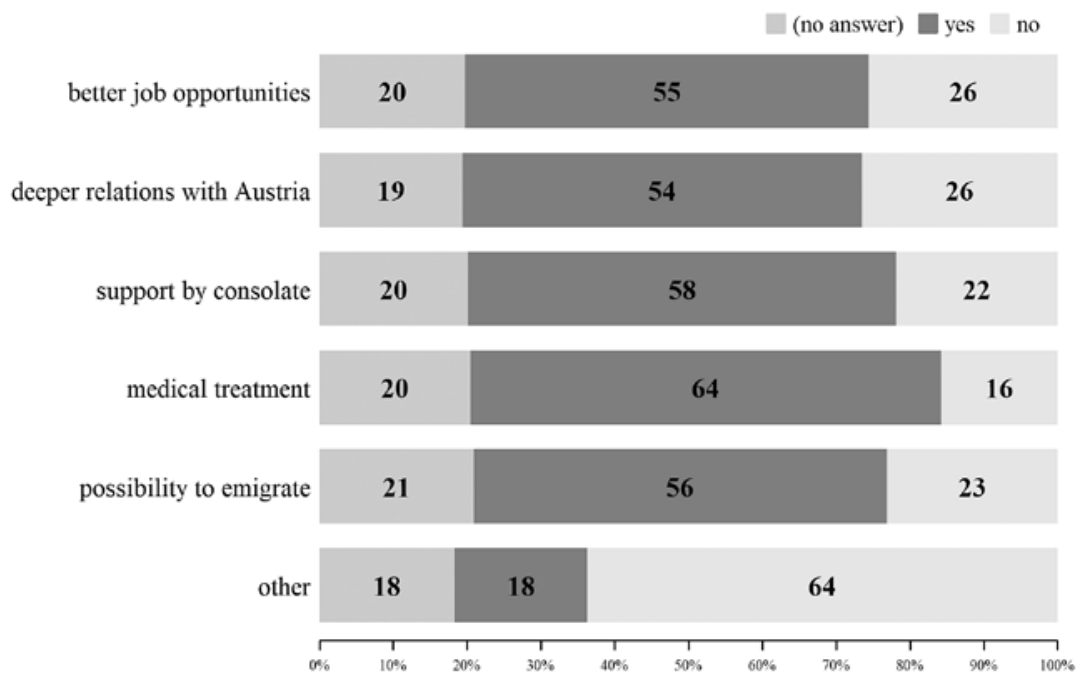

Why would one apply for Austrian citizenship at all if it were possible? In the questionnaire we listed five reasons for this. Figure 14.4 shows that all the reasons we mentioned are considered relevant. These reasons are: better chances of working in Austria; deepening one's relationship with Austria; support from Austrian consulates in the case of problems abroad; easier access to medical services in Austria; the possibility of emigrating to Austria in the case of a serious political or economic crisis in Italy. What is particularly important, however, is that the symbolic aspect of citizenship - deepening the relationship with Austria - is not mentioned more frequently than the more instrumental aspects.

Finally, one important question was related to the reasons for not applying for Austrian citizenship. By far the most frequently mentioned reason, at 60 per cent of respondents who are not interested in Austrian citizenship, is the statement "Italian citizenship is 
sufficient for me". A further 15 per cent also think that dual citizenship endangers ethnic cohabitation in South Tyrol. About the same number stated that they did not identify with Austria. In the reactions to these statements there are surprisingly small differences between the language groups; even for the statement "I don't identify with Austria", the difference is smaller than one would expect: 13 per cent of German-speaking and 26 per cent of Italian-speaking South Tyroleans explained their lack of interest in Austrian citizenship this way. This proves once again that the issue of dual citizenship is evaluated similarly by the two major language groups.

\subsection{The social determinants of the assessment of dual citizenship: a multivariate analysis $^{9}$}

A central question of this study is how strongly the attitudes of South Tyroleans to the offer of Austrian citizenship vary between the different population groups and what differences there are, especially between the German- and the Italian-language groups. The tabular analyses have already provided some indications. However, a scientifically sound statement can only be made on the basis of a multivariate analysis in which the effects of the different characteristics of the respondents are examined simultaneously. Ordinal logistic regression was used as a statistical analysis method for this purpose, as it is suitable when the variables are not scaled metrically (see Baltes-Götz 2012). In order to make the analysis manageable, questions with several categories were grouped together or partly dichotomised.

Four questions were included in the analysis as dependent variables to be explained:

- How important do you think citizenship is in a person's life? Very/rather/less/not at all?

- What is your basic position on this idea? [to give German- and Ladin-speaking South Tyroleans Austrian citizenship in addition to Italian citizenship?] Is this a very good idea a good idea/a problematic idea/to be rejected?

- Would you apply for Austrian citizenship yourself if it were possible? Yes, definitely/ Yes, under some circumstances/No, certainly not.

- What do you think? Would the granting of Austrian citizenship to South Tyroleans of German and Ladin language rather promote/rather impair/not have any effect on ethnic cohabitation in South Tyrol?

Five independent (explanatory) variables were included in the analysis: gender, age in four categories (18-34, 35-49, 50-64 and 65 years and older), level of education (dichotomised into the categories: less than high school/high school and university degree), resi-

9 These statistical analyses were carried out by Alice Forlin, former trainee at apollis - Institute of Social Research and Opinion Polling, Bolzano-Bozen. 
dential area (urban/rural municipalities) and language group in two categories (German and Ladin/Italian). The results can be summarised in two respects, firstly concerning the questions involved and secondly with regard to which variables provide the best explanation for the attitudes (see Table 14.3).

Regarding the determinants of the different dimensions of attitudes towards dual citizenship, the following can be noted:

- The importance of citizenship in general: only two variables, gender and age, have a significant effect; men consider it less important compared to women; younger people (18-34) and middle-aged adults (50-64) consider citizenship less important compared to older people (65+). However, the model explains only a very small part of the overall variance.

- The assessment of dual citizenship for South Tyroleans: three variables are significant. Younger people (18-34) and adults under 50 (35-49) tend to view the idea more favourably than older people (people aged 65+); city dwellers reject the idea more strongly than inhabitants of rural communities; German-speaking South Tyroleans tend to view the idea more positively than Italian-speaking ones, who reject it relatively unanimously.

- Personal intention to apply for Austrian citizenship: here only two variables are significant. Men are more likely to apply than women; the younger a person is, the more interested he or she is in Austrian citizenship in addition to Italian citizenship (significant for all age groups).

- Consequences of dual citizenship for ethnic cohabitation in South Tyrol: four variables are significant. Men tend to see more positive effects, as do younger people (18-34) compared to those over 65; city dwellers as well as German-speaking South Tyroleans see positive effects more often than Italian-speaking South Tyroleans.

Not only in relation to the first question - where the explanatory power of the model is minimal despite the significant coefficients identified - but also in relation to the other three questions examined, the explanatory power of the statistical models is quite low (maximum 10 per cent of the total variance). This means, then, that the attitudes of South Tyroleans towards dual citizenship have little to do with socio-demographic characteristics; they are obviously essentially determined by other factors. These could be basic political and social orientations, specific milieu influences or personal experiences - all dimensions that we have not or have only partially covered in this survey.

These results confirm the tabular analyses. The most important finding here is that membership in a language group has relatively little significance for attitudes towards dual citizenship. By far the most important variable is age: younger people obviously already have a much clearer strategic-instrumental attitude towards citizenship in general and towards the dual passport for South Tyroleans in particular than older people. 
Table 14.3. Multivariate analysis of the social determinants of attitudes towards dual citizenship (ordinal logistic regressions)

\begin{tabular}{|c|c|c|c|c|c|}
\hline & \multicolumn{5}{|c|}{ Dependent variable (question) } \\
\hline & \multirow{2}{*}{$\begin{array}{c}\text { Impor- } \\
\text { tance of } \\
\text { citizenship }\end{array}$} & \multirow{2}{*}{$\begin{array}{c}\text { Dual } \\
\text { citizenship } \\
\text { - a good } \\
\text { idea? }\end{array}$} & \multirow{2}{*}{$\begin{array}{l}\text { Would } \\
\text { you } \\
\text { apply? }\end{array}$} & \multicolumn{2}{|c|}{$\begin{array}{l}\text { Impact on ethnic } \\
\text { cohabitation }+ \text { ) }\end{array}$} \\
\hline & & & & $\begin{array}{l}\text { Quite } \\
\text { positive }\end{array}$ & $\begin{array}{c}\text { Quite } \\
\text { negative }\end{array}$ \\
\hline & \multicolumn{5}{|c|}{ Parameter-Estimates (ordered logits +++ ) } \\
\hline $\begin{array}{l}\text { Gender } \\
\text { (ref. female }\end{array}$ & $.36^{*}$ & $++)$ & $-.39 *$ & $-.58^{*}$ & -.19 \\
\hline \multicolumn{6}{|l|}{ Age group in years (ref. 65+) } \\
\hline $18-34$ & $.75^{* *}$ & $-1.17^{* *}$ & $-1.41^{* *}$ & $1.16^{*}$ & -.06 \\
\hline $35-49$ & .45 & $-.51^{*}$ & $-.99^{* *}$ & .23 & .49 \\
\hline $50-64$ & $.42^{*}$ & -.12 & $-.60^{* *}$ & .24 & .18 \\
\hline $\begin{array}{l}\text { Education level (ref. high school/ } \\
\text { university) }\end{array}$ & -.00 & .05 & .20 & .12 & -.31 \\
\hline $\begin{array}{l}\text { Residential area (ref. rural } \\
\text { municipalities) }\end{array}$ & .00 & $.57^{* *}$ & .14 & $-.77^{*}$ & -.06 \\
\hline $\begin{array}{l}\text { Affiliation to language group } \\
\text { (ref. Italian lang.) }\end{array}$ & .06 & $-.63^{* *}$ & -.40 & $-1.31^{* *}$ & -.24 \\
\hline Goodness of fit (Pearson) & 181.41 & 82.48 & 125.58 & & - \\
\hline \multicolumn{6}{|l|}{ Pseudo R-Square } \\
\hline Cox \& Snell & .02 & .12 & .07 & .0 & 6 \\
\hline Nagelkerke & .03 & .13 & .09 & .0 & 7 \\
\hline
\end{tabular}

Statistical significance: *: <.05, **: <.01;

+) Multinomial logistic regression (the characteristic does not have an ordinal scale level).

$++)$ Variable excluded because its inclusion would violate model assumptions.

$+++)$ The coefficient represents the natural logarithm of the estimated odds ratio between the respective category and the reference category; positive values mean that the responses with the higher code are given more frequently than in the reference category, negative values mean the opposite. Example: 18-34-year-old persons have about twice as much chance of finding citizenship unimportant as people over 65 (with otherwise identical socio-demographic values, since $\ln 0.75=2.12$ ).

This means that the worldwide trend towards liberalisation, instrumentalisation and the opening of the concept of citizenship (Joppke 2010; Spiro 2016) is also present among the South Tyrolean population. Many activists and members of the right-wing parties in South Tyrol, which promote the idea of dual citizenship, are also younger people. These results are consistent with numerous studies on political attitudes and participation which show that younger people generally tend to be less interested in traditional politics than older people, are more critical of the established political elites and also tend not to value the existing political system - and even democracy itself - 
as highly as older people (for South Tyrol see Pallaver 2016; more generally, Mounk 2019; Weßels 2018).

\subsection{A short look at comparable minorities in Central Eastern Europe}

Fortunately, studies comparable to our survey have been carried out among ethnic minorities living in Slovakia, Serbia and Ukraine who find themselves in a similar situation. As a consequence of the redrawing of Hungary's borders in the 1920 Treaty of Trianon, more than two million ethnic Hungarians live in neighbouring countries (Slovakia, Yugoslavia, Romania and Ukraine). It is a matter of fact that the situation of the Hungarian minorities in adjacent countries is not as good as that of South Tyroleans, who obtained a particularly strong regional self-administration. In addition, Serbia and Ukraine are still not members of the European Union so Hungarians living there might be interested in Hungarian citizenship for instrumental reasons - to gain access to the huge EU labour market. However, in Slovakia and Romania, ethnic Hungarians are granted all civic and political rights and children have the possibility to attend school in their mother tongue. Two comparable surveys were carried out among the minorities concerned and their findings are very relevant for our study as well.

In 2009-2010, a representative survey among about 800 ethnic Hungarians living in Slovakia was carried out (as part of the EC ENRI-East project), supplemented by in-depth interviews and by a survey among Slovaks in Hungary (Machacek 2011). The survey found that ethnic Hungarians in Slovakia in general find themselves in a good situation, all basic rights are provided and the use of the Hungarian language is guaranteed. The survey asked which personal and social characteristics (age, gender, occupation, citizenship, ethnic identity etc.) were the most important for the respondents. It turned out that all are important but none is prevalent; only for 18 per cent was ethnic identity the most important component of identity - somewhat less than gender identity. The most important levels of identification were the local (Slovaks in Hungary) and regional ones (Hungarians in Slovakia). The dominant form of identification (endorsed by 65 per cent) was: "I am a Hungarian living in Slovakia". Similar results were obtained in surveys among ethnic Hungarians in Slovakia and ethnic Romanians in Serbia and Ukraine, carried out by an international research team (Iglesias, Sata and Vass 2016) in 2013-2014. In their study, semi-structured interviews were carried out with about 70 individuals and discussions held with 14 focus groups. This study also found that Hungarians in Slovakia are guaranteed all basic rights but, nevertheless, felt torn by some feelings of insecurity ("We are taxpayers but do not feel that we have a homeland"). Romanians living in Serbia and Ukraine felt more secure. All of them, however, had very strong regional identities; sometimes, even an "idealised view" of their multicultural region emerged. At the same time, in both studies the ethnic minorities did not feel close to the people in their cultural "homeland". Some ethnic Hungarians in Slovakia told us that they were not considered as "true" Slovakians by their co-citizens nor as real Hungarians by people 
in Hungary. Asked about their interest in Hungarian citizenship, the results were quite similar to those obtained in South Tyrol - there was little interest. Among these minorities, citizenship in their present state was not considered as an "empty shell... there is a sense of identification with and maybe even loyalty to the state" because it provided all basic rights and opportunities for political participation (Iglesias et al. 2016, 27). In both studies, there was also little interest in obtaining the citizenship of the ethnic kin state.

Thus, we can conclude that these findings strongly support our results obtained for South Tyrol. Ethnic minorities who had long been living on the territory of another, state enjoying all political and social rights and some degree of autonomy, identified mostly with their place and region of living but not with their ethnic kin state. This finding is also in line with the argument proposed in Chapter 2 by Haller in this volume - that it is the concrete living experience over generations which determines ethno-national attitudes.

\section{Summary}

The main topic of this study was to investigate the attitude of the South Tyrolean population towards a policy proposal announced by the Austrian government - namely to grant an additional Austrian citizenship to German- or Ladin-speaking inhabitants of South Tyrol (who are Italian citizens). This specific question was integrated into a larger theoretical and political context in two ways: on the one hand the importance attached to citizenship by the people; on the other, the political units with which the South Tyroleans identify today, especially their relationship to Austria. A focus was put on the differences between language groups in their perceptions and attitudes with regards to the proposal of dual citizenship and related issues.

The main findings can be summarised as follows:

- Citizenship is, as expected, an important aspect of social integration for the South Tyroleans. They express an open and inclusive attitude in this respect: the clear majority is in favour of allowing dual citizenship as well as facilitating the naturalisation of immigrants.

- With regards to ethno-territorial affiliation, our study confirms the results of several previous surveys: the vast majority of respondents identify primarily with "South Tyrol" (Südtiroler/in, Sudtirolese or Altoatesino/a); this also applies to a good half of the Italian-speaking South Tyroleans. In second place we find the self-classifications "European" and "World citizen" followed by "Italian" (Italian-speaking respondents identify as often with Italy as with South Tyrol). Only very small proportions of German- and Ladin-speaking respondents categorise themselves as Tyroleans, Austrians or Germans. Questions as to whether the respondent has relatives and friends there and how often he or she visits Tyrol or Austria revealed that many South Tyroleans in practice have relatively close relations to Austria. More than half of the 
German-speaking respondents regularly follow the news on Austrian TV or radio programmes; among the Italian-speaking, the proportions are of course significantly lower. South Tyroleans are very well informed about the proposition to grant them additional Austrian citizenship. However, only about a quarter of them consider this a (very) good idea; one third find it problematic while another third think it should be completely rejected. Of the respondents, 40 per cent believe that dual citizenship is likely to impair the (peaceful) cohabitation of the language groups in South Tyrol; even among members of the German-language group, only a minority sees positive effects.

- The findings on the central issue - the respondents' own interest in dual citizenship - are surprisingly clear: only about one third of South Tyroleans declare an intention to eventually take up the offer of Austrian citizenship (12 per cent "definitely", 22 per cent "under certain circumstances").

- Those respondents who expressed a concrete interest in Austrian citizenship would expect better job opportunities in Austria and access to medical services there, easier opportunities to emigrate to Austria in the event of a deep crisis in Italy, support from Austrian consulates in foreign countries in case of emergencies and also the deepening of relations with Austria. This last purely intrinsic, identity-related motivation does not play a special role but turns out to be roughly as strong as instrumental ones.

The most astonishing result of the study is not so much that scepticism about the proposition of an additional Austrian citizenship prevails but that there are only very small differences between German-, Ladin- and Italian-speaking South Tyroleans concerning this issue.

Generally, the South Tyrolean society is described as a good example of the resolution of ethnic conflicts but, at the same time, as only a partially integrated multi-ethnic society. Therefore, it was quite unexpected to discover such a homogeneity in the attitudes regarding the proposition of additional Austrian citizenship between the ethnic-linguistic groups. In political terms, this means that granting the additional Austrian citizenship only to a part of the population, namely members of the German- and the Ladin-language groups, would not take account of the similarity of perceptions with respect to that question within the South Tyrolean society. Instead of achieving the presumed aim of strengthening relationships with the fatherland, it could in fact endanger social and political cohesion in South Tyrol.

It could be assumed that the low interest in such dual citizenship shown in this study is due to the fact that it would bring very few real benefits in the case of South Tyrol: in particular, the membership of the European Union of the two states concerned - Italy and Austria - and the high level of minority protection enjoyed by the German- and Ladin-speaking populations through the special autonomy could be responsible for this. However, it seems that, in addition to these instrumental reasons, the strength of 
regional identity compared to that of an external kin minority is also involved. The findings of our study are corroborated by very similar results obtained by surveys among ethnic Hungarians living in Slovakia and Romanians living in Serbia and Ukraine. In those cases, too, the main form of social and political identity was the affiliation to the region where people live. This region is seen - quite comparably to South Tyrol - as being characterised by specific positive features. There is thus little interest in obtaining the citizenship of the ethnic kin state.

Therefore, we can conclude that the proposal to grant additional Austrian citizenship to a part of the population of South Tyrol is not an issue favoured by the people concerned. On the contrary, it could damage the efforts of responsible local politicians to present the special autonomy of South Tyrol not only as an instrument of minority protection but also as a common anchor of identification for all people living in the province, especially also for members of the Italian-language group. The activities of separatist parties and movements that would interpret dual citizenship as a first step towards the separation of South Tyrol from Italy are certainly undermining such efforts to some degree. In order to intensify the relations of all parts of the South Tyrolean population with Austria, it would seem much more promising to strengthen the European region of Tyrol-South Tyrol-Trentino, a move which should not only take place at the level of the political and scientific elites but which should also involve ordinary citizens. For this to happen, what is needed is not so much an additional passport as an open border, real opportunities for personal encounters and more exchange in the political, economic, social and cultural spheres, so that individual added value is created.

\section{References}

ASTAT 2006. Südtiroler Sprachbarometer/Barometro linguistico dell'Alto Adige - 2004. Bolzano: Autonome Provinz Bozen/Landesinstitut für Statistik.

ASTAT 2015. Südtiroler Sprachbarometer/Barometro linguistico dell'Alto Adige - 2014. Bolzano: Autonome Provinz Bozen/Landesinstitut für Statistik.

Atz, H. and Forlin, A. 2020. Le appartenenze territoriali ed etniche degli altoatesini, in Pallaver, G., Alber, E. and Engl, A. (eds) Politika 20. Südtiroler Jahrbuch für Politik/Annuario dipolitica dell'Alto Adige/Anuar de politica dl Südtirol. Bolzano: Edition Raetia, 181-204. Atz, H., Haller, M. and Pallaver, G. (eds) 2016. Ethnische Differenzierung und soziale Schichtung in der Südtiroler Gesellschaft. Ergebnisse eines empirischen Forschungsprojekts. Baden-Baden: Nomos.

Baltes-Götz, B. (2012). Logistische Regressionsanalyse mit SPSS. Available at: https://www. uni-trier.de/fileadmin/urt/doku/logist/logist.pdf (accessed 29 December 2020).

Denicolò, G. and Pallaver, G. 2018. Doppelstaatsbürgerschaft für Südtiroler/-innen: Verzicht auf Alleingänge, in Alber, E., Engl, A. and Pallaver, G. (eds) Politika 2018. Südtiroler Jahrbuch für Politik. Bolzano: Edition Raetia, 255-280. 
Dumbrava, C. 2014. Nationality, Citizenship and Ethno-Cultural Belonging: Preferential Membership Policies in Europe. Basingstoke: Palgrave Macmillan.

Haller, M. 2006. South Tyrol - an economic or political success story? An investigation of the factors contributing to the solution of an ethnic-national conflict, in von Hartungen, C., Heiss, H. and Pallaver, G. (eds) Demokratie und Erinnerung. Südtirol-Österreich - Italien. Innsbruck, Vienna and Bolzano: Studien Verlag, 131-154.

Hilpold, P. 2016. Die doppelte Staatsbürgerschaft im Völkerrecht, Europa Ethnica, 76(1-2): 2-4.

Iglesias, J.D., Sata, R and Vass, Á. 2016. Citizenship and identity: being Hungarian in Slovakia and Romanian in Serbia and Ukraine, Minority Studies, 18: 15-32.

Joppke, C. 2010. The inevitable lightening of citizenship, European Journal of Sociology/ Archives européennes de sociologie, 51(1): 9-32.

Machacek, L. 2011. Slovak republic and its Hungarian ethnic minority: sociological reflections, Slovak Journal of Politicial Sciences, 11(3): 187-210.

Mounk, Y. 2019. The People vs Democracy. Why Our Freedom Is In Danger and How To Save It. Cambridge, MA: Harvard University Press.

Obwexer, W. 2011. Gutachten: Rechtliche Rahmenbedingungen für den Erwerb der österreichischen Staatsbürgerschaft durch "Südtiroler". Innsbruck: Leopold-Franzens-Universität.

Palermo, F. 2020. 'Doppio passaporto': uno sguardo comparato e qualche riflessione sulle misure di promozione di minoranze residenti all'estero, in Pallaver, G., Alber, E. and Engl, A. (eds) Politika 20. Südtiroler Jahrbuch für Politik/Annuario di politica dell'Alto Adige/Anuar de politica dl Südtirol. Bolzano: Edition Raetia, 205-226.

Pallaver, G. 2016. Politische Partizipation und ethnische Zuordnung, in Atz, H., Haller, M. and Pallaver, G. (eds) Ethnische Differenzierung und soziale Schichtung in der Südtiroler Gesellschaft. Baden-Baden: Nomos, 289-312.

Pallaver, G. 2018. Südtirols Parteien. Analysen, Trends und Perspektiven. Bolzano: Edition Raetia.

Peterlini, O. 2019. Ein Pass für Nachfahren österreichischer Staatsbürger, Europa Ethnica, 76(1-2): 23-31.

Pogonyi, S. 2017. Extra-Territorial Ethnic Politics, Discourses and Identities in Hungary. London: Palgrave.

Spiro, P.J. 2016. At Home in Two Countries. The Past and Future of Dual Citizenship. New York: New York University Press.

Steininger, R. 2003. Südtirol. Vom Ersten Weltkrieg bis zur Gegenwart. Innsbruck, Vienna, Munich and Bolzano: StudienVerlag.

Südtiroler Landesregierung 2019. Südtirol-Handbuch mit Autonomiestatut. Bolzano: Südtiroler Landesregierung (eds).

SVP Club 2018. Doppel-Staatsbürgerschaft für Südtiroler. Eine europäische Geste des Vaterlandes Österreich als Ausdruck der Verbindung mit der österreichischen Minderheit und 
zur Vertiefung der österreichisch-italienischen Freundschaft im europäischen Geist, Bozen, 15.2.2018, 70-Punkte-Info. Available at: https://www.salto.bz/sites/default/files/ atoms/files/doppelstaatsburgerschaft___lange_version.pdf (accessed 28 November 2020).

Traweger, C. and Pallaver, G. 2018. Die Europaregion Tirol-Südtirol-Trentino. Erwartungen und Potentiale. Ergebnisse einer Bevölkerungsbefragung. Innsbruck: EVTZ Europaregion Tirol-Südtirol-Trentino.

Weßels, B. 2018. Politisches Interesse und politische Partizipation. Datenreport 2018. Bundeszentrale für politische Bildung. Available at: https://www.bpb.de/nachschlagen/datenreport-2018/politische-und-gesellschaftliche-partizipation/278492/politisches-interesse-und-politische-partizipation (accessed 28 November 2020). 

The toleration of dual citizenship has become

a global trend as states try to retain ties to their emigrants

or to encourage their immigrants to naturalise.

This volume examines changes in state attitudes to dual citizenship and their social impact from political science, sociological and legal perspectives. It zooms in from analyses of global dynamics to a series of European case studies that illustrate the variety of reasons and intentions behind dual citizenship reform.

Finally, five chapters provide the most thorough analysis of the special Austrian case so far. They show the size of Austria's untapped potential for naturalisation of immigrants, the incoherence of its citizenship policies at home and abroad and the need for a comprehensive reform.

RAINER BAUBÖCK is Professor at the European University Institute, Florence and chair of the Commission for Migration and Integration Research/ÖAW.

MAX HALLER is em. Prof. of Sociology at the University of Graz and vice-chair of the Commission for Migration and Integration Research/ ÖAW.

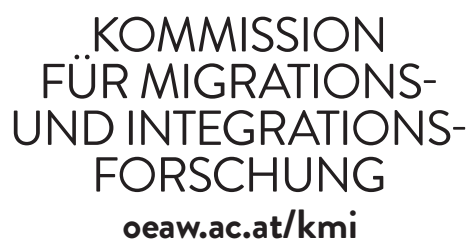

ISBN 978-3-7001-8775-2

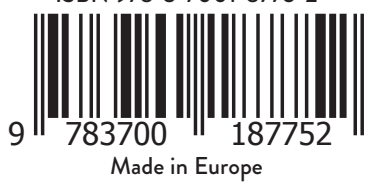

